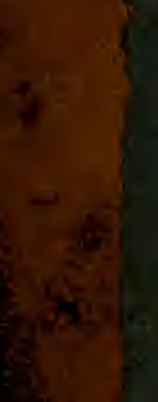

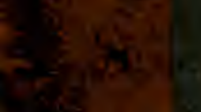

14.
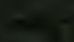


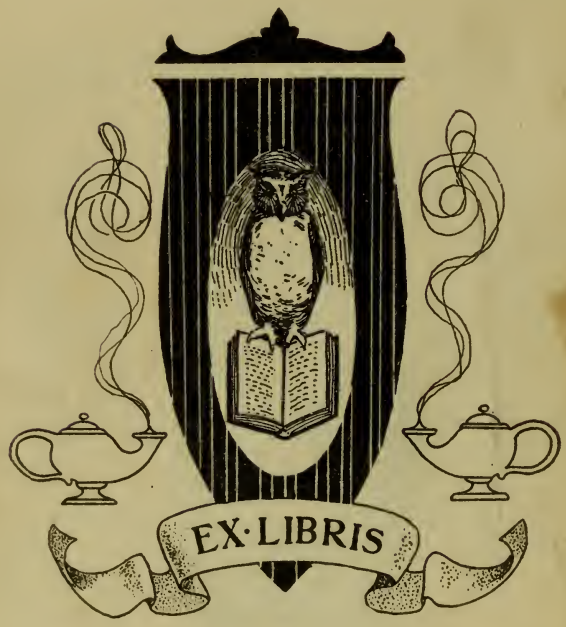

S. G. \& E. L. ELBERT 


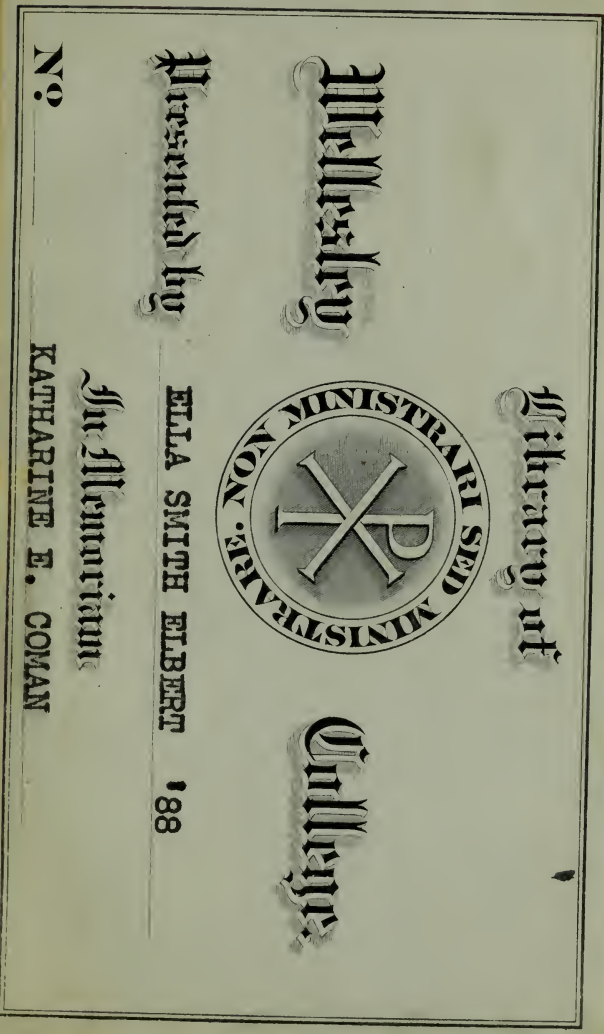


$=1$

$=$

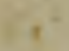

1

1

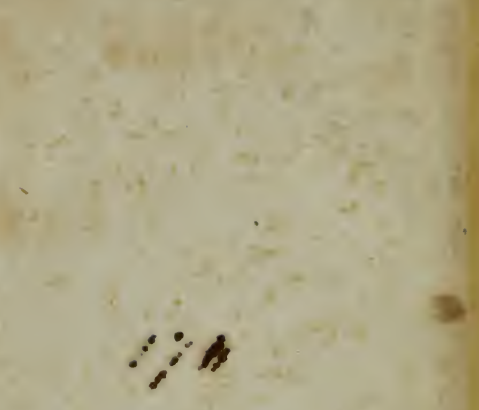

$+$

$y^{2}+2$

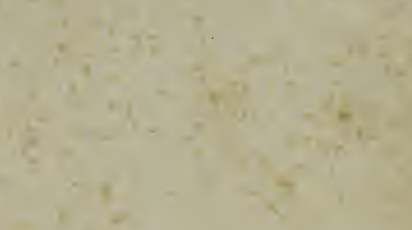

$-2+2=1-2$

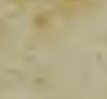

16

$$
+1
$$


( Shassil) $\sum_{1864} 7000$ 


$$
\begin{aligned}
& \therefore 0.0000, \\
& \text { puis }
\end{aligned}
$$




\section{FAMILY CLASSICAL LIBRARY.}

To those who are desirous of obtaining a knowledge of the most teemed authors of Greece and Rome, but possess not the means or leisure for pursuing a regular course of study, the present undertaking must prove a valuable acquisition.

So diversified are the objects to which general education is at present tirected, that sufficient time calnot be allowed, in most instances, to lay the foundation of an adequate acquaintance with the most popular authors in the Greek and Latin languages. In those instances even, in which the object has been attained, where the taste bas been formed, and the habit of occasional recurrence to the Classics has been preserved, the facility of reference to a Series of correct and elegant Translations must afford pleasure, and occasional assistance, even to the scholar. To him who, as Dr. KNox observes, although engaged in other pursuits, is still anxicus to "retain a tincture of that elegance and liberality of sentiment which the mind acquires by the study of the Classics, and which contributes more to form the true gentleman than all the unsubstantial ornaments of modern affectation," such a collection will, it is confidently hoped, prove acceptable.

As the learned languages do not form part of the education of females, the only access which they have to the valuable stores of antiquity is through the medium of corrert translation.

The selection is intended to include those authors whose works may with propriety be read by the youth of both sexes; and it will be obvious that the nature of the publication is of so permanent a character, as to prove equally interesting to posterity as to the present generation. The whole will be presented to the public in a cheap, handsome, and uniform size, forming a complete "Family Classical Library," alike useful for the purpose of instruction and amusement. Indeed, as Dr. PARR says, "if you desire your son, though no great scholar, to read and reflect, it is your duty to place in his hands the best translations of the best Classical Authors."

A Biographical Sketch will be prefixed to each author; and notes will be added, when necessary for the purpose of illustration. Engravings of the authors, and Maps, will be given occasionally.

The importance attached in the present day to translations of the classic authors, may be estimated by the fact, that a series has been recently published in England, and also in France, and that another in the Russian language is now in progress, under the immediate sanction of the Imperial Government.

\section{AN EPITOME OF ENGLISH LITERATURE.}

UNDER the above title it is intended to publish, in a new and concentrated form, a series of Standard English Authors. The precise nature of the plan to be adopted in the work will be stated hereafter,-for the present suffice it to observe, that in History no facts, and in Philosophy no reasoning will be omitted or distorted, so as to render a reference to the original author requisite; and thus persons of both sexes may become perfectly acquainted with authors repulsive from bulk alone, at a comparatively little cost of time as well as price. The series will be confined to the popular productions of writers in prose,-such as Burnet, Clarendon, Gibbon, Hume, Robertson, Bacon, Locke, Paley, Addison, Goldsmith, Johnson, Swift, \&ce. \&c., and will be edited by A. J VALPY, M. A.

\section{HARPER'S FAMILY LIBRARY.-See Prospectus.}

\section{LIBRARY OF SLLECT NOVEI.S.-See Prospectus}




\section{HARPER'S FAMILY LIBRARY.}

The following opinions, selected from highly respectable Journais, will enable those who are unacquainted with the Family Library to form an estintate at' its merits. Numerous other notices, equally favourable, and from sources equally respectable, might be presented if deeined necessary.

"The Fainily Library.-A very excellent, and always entertaining Miscellany."-Edinburgh Review, No. 103.

"'The Family Library presents, in a compendious and convenient form, well-written histories of popular men, kingdoms, sciences, \&c. arranged and edited by able writers, and drawn entirely from the inost correct and accredited authorities. It is, as it professes to be, a Family Library, from which, at little expense, a household may prepare themselves for a consideration of those elementary subjects of education and society, without a due acquaintance with which neither man nor, woman has clain to be well bred, or to take their proper place among those with whom they abide."-Charleston Gazette.

"We have repeatedly borne testimony to the utility of this work. It is one of the best that has ever been issued from the American press, and should be in the library of every family desirous of treasuring up useful knowledge."-Boston Statesman.

"The Family Library should be in the hands of every person. Thus far it has treated of subjects interesting to all, condensed in a perspicuous and agreeable style...... We have so repeatedly spoken of the merits of th. design of this work, and of the able manuer in which it is edited, that on this uccasion we will only repeat our conviction, that it is worthy a place in every library in the country, and will prove one of the most useful as it is one of the inost interesting publications which has ever issued from the American press." $-N$. Y. Courier \& Enquirer.

"The Family Library is, what its name implies, a collection of various original works of the best kind, cuntaining reading, useful and interesting to the family circle. It is neatly printed, and should be in every family that can afford it-the price being moderate."-New-Engiand Palladium.

"The Family Library is, in all resperts, a valuable work."-Pennsyl vania Inquirer.

"Wo are pleased to see that the publishers have obtained sufficient encouragement to continue their valuable Family Library."-Baltimore Republican.

"We recommend the whole set of the Family Library as one of the cheapest means of affording pleasing instruction, and imparting a proper pride in books, with which we are acquainted."-Philadelplia U. S. Guzette.

"It will nrove instructing and amusing to all classes. We are pleased to learn th the works comprising this Library bave become, as they ought to be, quite popular among the heads of Families." $-N$. Y. Gazette.

"It is the duty of every person having a family to put this excellent Library into the hands of his children." $-N$. $Y$. Mercantile Advertiser.

"We have so often recommended this enterprising and useful publica tinn ('he Family Library), that we can here only idd, that each successive numb'r appears to confirm its merited popularity." $-N$. $Y$. American.

"It is so emphatically what it purports to be, that we are anxious to seo it in every family.-It is alike interesting and useful to at classes of readers."-Albany Evening Journal.

"The little volumes of this series truly comport with their title, and are in themselves a Family Library." $-\boldsymbol{N}$. Y . Commercial Advertiser.

"We have met with no work more interesting and deservedly popular than this valuable Family Library."-Monthly Repository.

"The plan of the Family Library must be acceptable to the American reading coinmunity." $-N$. Y. Journal of Commerce.

"To all portions of the cornmunity the entire series may be warmly reccmmended." - American Traveller.

"It is a delightful publication."-Trut's Tcller. 


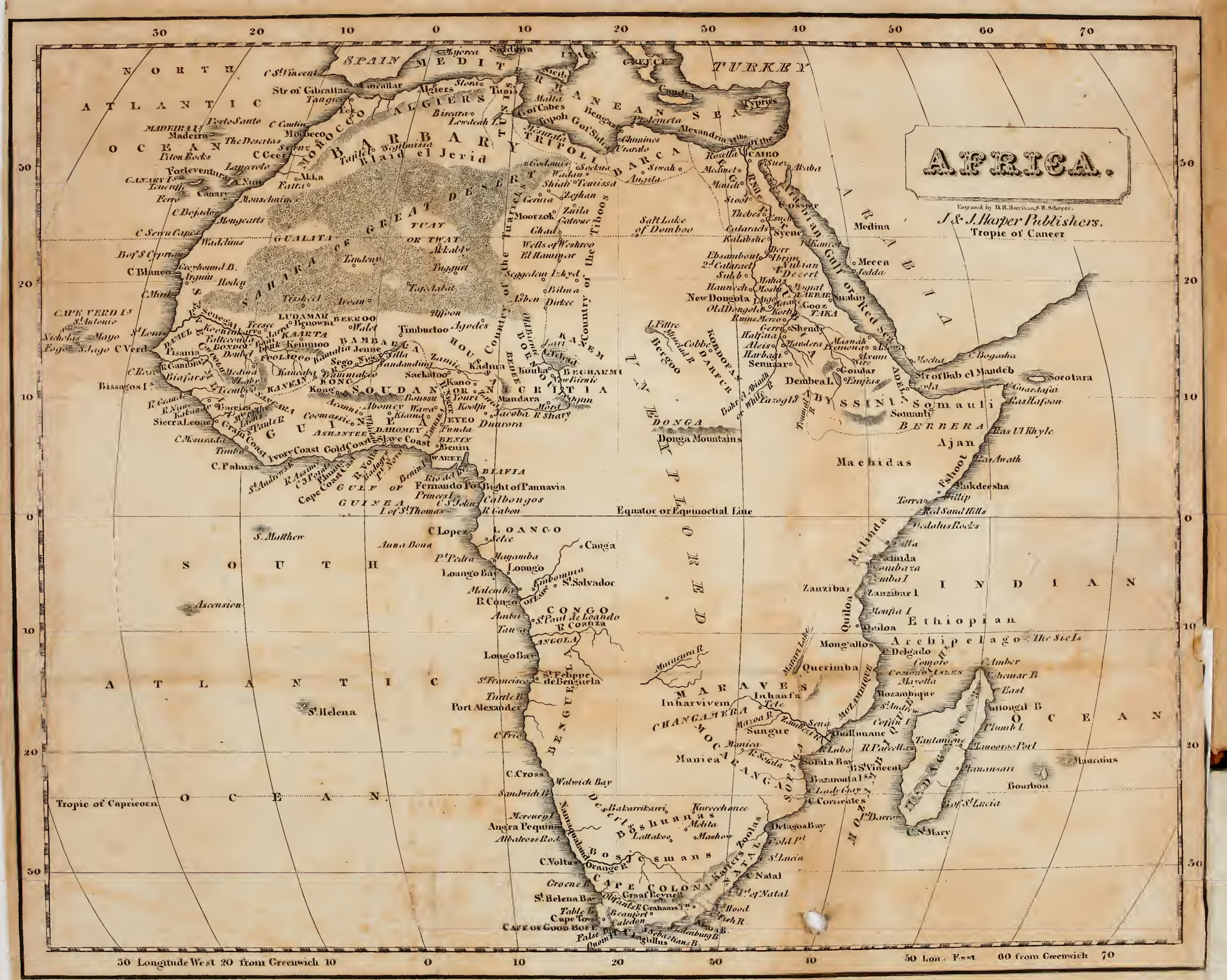





\section{DISCOVERY AND ADVENTURE}

IN

\section{AFRICA.}

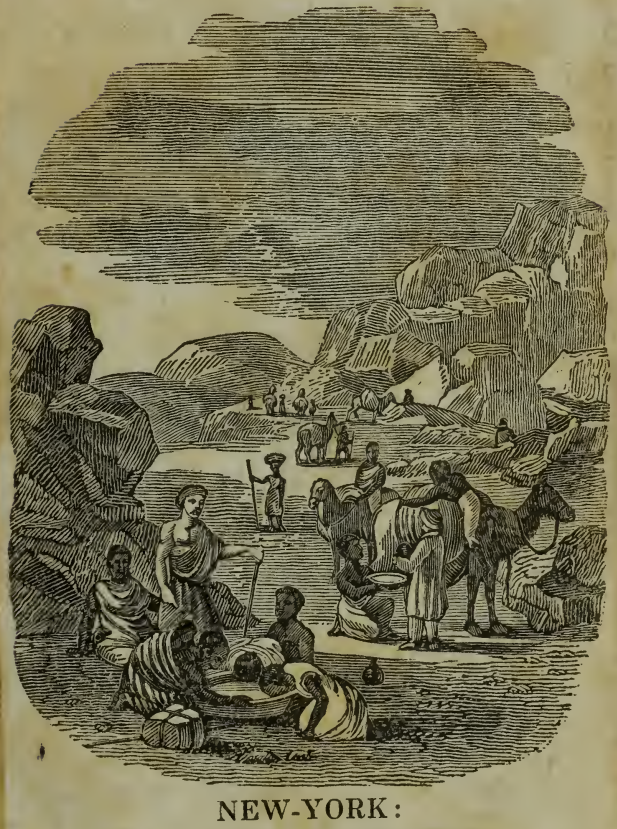

J. \& J. HARPER, 82 CLIFF-STREET. 
.

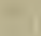
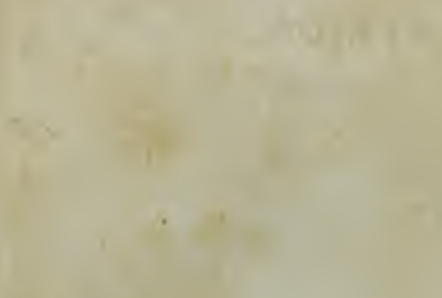

$\sqrt{2}+x^{2}$

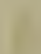

1
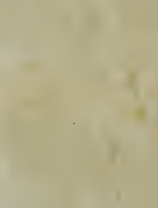

n<smiles>C1CCCCC1</smiles>

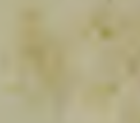

I

nand 


\section{Harper's Stereotype Edition.}

\section{NARRATIVE}

OF

\section{DISCOVERY AND ADVENTURE}

FRQOM THE EARLIEST AGES TO THE PRESENT TIME:

WITI ILLUSTRATIONS OF THE.

GEOLOGY, MINERALOGY, AND ZOOLOGY.

BY PROFESSOR JAMESON, JAMES WILSON, ESQ., F.R.S.E., AND HUGH MURRAY, ESQ., F.R.S.E.

WITH A MAP; PLANS OF THE ROUTES OF PARK, AND OF DENHAM AND CLAPPERTON; AND SEVERAL ENGRAVINGS.

\section{NEW-YORK :}

PRINTED AND PUBLISHED BY J. \& J. HARPER, NO. 82 CLITF-STREET.

AND SOT.D BY THE PRINCIPAL BOOKSELLERS THROUGHOUT THE UNITED "sTATES. 


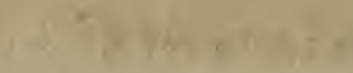

$\sqrt{1}$

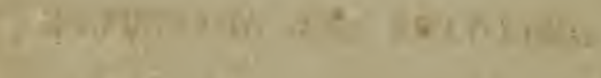

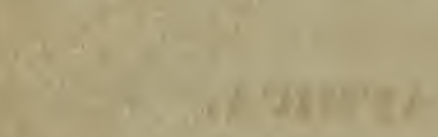

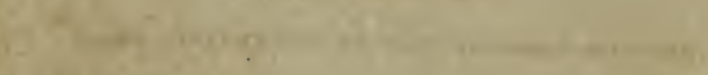

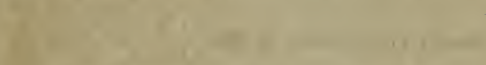

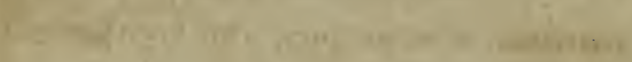
1

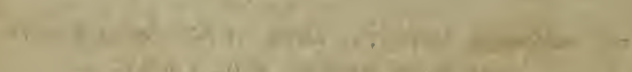

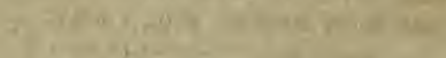

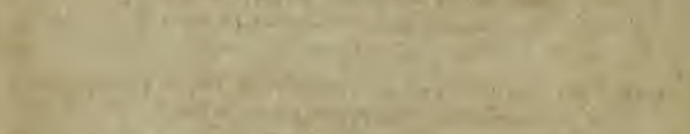
1.

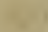

a) $=0$

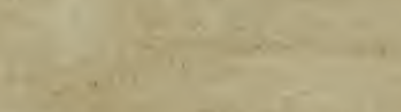

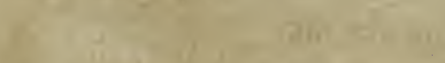

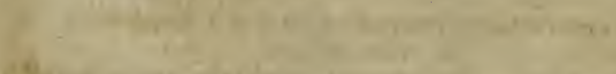

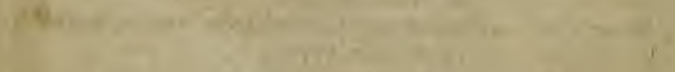

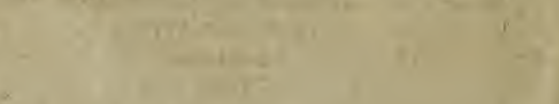




\section{P R E F A CE.}

THE object of this volume is to exhibit, within a moderate compass, whatever is most interesting in the adventures and observations of those travellers who, from the earliest ages, and in various directions, have sought to explore Africa; and also to give a general view of the physical and social condition of that extensive continent at the present day. This quarter of the globe has afforded more ample scope than any other to the exertions of that class of men whose enterprising spirit impels them, regardless of toil and peril, to penetrate into unknown countries. Down to a comparatively recent period, the greater part of its immense surface was the subject only of vague report and conjecture. The progress of those discoverers, by whom a very large extent of its interior regions has at length been disclosed, having been accompanied with arduous labours, and achieved in the face of the most formidable obstacles, presents a continued succession of striking incidents, as well as of new and remarkable objects : and our interest cannot fail to be heightened by the consideration, that Britain, by the intrepid spirit of her travellers, her associations of distinguished individuals, and her national patronage, has secured almost the exclusive glory of the many important discoveries which have been made within the last forty years.

The work now submitted to the public, and the recent one on the Polar Regions, embrace two of the most interesting fields of modern discovery. The adventurers who traversed these opposite parts of the world frequently found their efforts checked, and their career arrested, by the operation of causes which, although equally powerful, were yet extremely dif- 
ferent in their nature. In the Northern Seas, they suffered from that dreadful extremity of cold to which high latitudes are exposed; in Africa, from the scorching heat and pestilential vapours peculiar to a tropical climate: there, they encountered the fury of oceans and tempests ; here, the privations and fatigues which oppress the traveller in parched and boundless deserts. In the former they had less to endure from that almost total absence of human life which renders the Arctic zone so dreary, than they had to experience in the latter from the fierce, contemptuous, and persecuting character of the people who occupy the interior parts of the Libyan continent. In a word, while exploring these remote regions, they braved almost every species of danger, and passed through every variety of suffering, by which the strength and fortitude of man can be tried.

The Narrative of these successive Travels and Expeditions has been contributed by Mr. Hugh Murray. The Geological Illustrations have been furnished by the justly celebrated Professor Jameson; and for the interesting and very ample account of its Natural History the reader is indebted to Mr. James Wilson, author of "Illustrations of Zoology," and the principal contributor in that branch of science to the new edition of the Encyclopædia Britannica.

The present volume, having for its main object the History of Discovery and Adventure, does not include the countries on the Mediterranean coast, which from the earliest ages have been well known to the nations of Europe.-Egypt, again, from its high antiquity, its stupendous monuments, and the memorable revolutions through which it has passed, presented matter at once too interesting and ample to be comprehended within such narrow limits. The history of that kingdom, therefore, has been reserved for a separate volume, which will contain also an account of Nubia and Abyssinia.

Edingurgh, 20th November, 1830. 


\section{CONTENTS.}

\section{CHAPTER I.}

GENERAL VIEW OF THE NATURAL FEATURES OF AFRICA.

Introductory Observations-Its Situation on the Globe-Extensive Deserts-Mountains and Rivers-Vegetable Life-Animal Life-Social Aspect-Striking Contrasts which it presents ............ Page 13

\section{CHAPTER II.}

KNOWLEDGE OF AFRICA AMONG THE ANCIENTS.

Northern Africa well known-Obstacles opposed by the Desert-Description given by Herodotus-by Diodorus-by Strabo-Ancient Accounts of the Nile- of Ethiopia- of Abyssinia-Expedition sent by Necho-Journey of the Nasamones-Voyage of Sataspes-of HannoVoyages of Eudoxus-Periplus of the Erythrean Sea $\ldots \ldots \ldots \ldots \ldots 22$

\section{CHAPTER III.}

SETTLEMENTS OF THE ARABS.

Their Influence on this Continent-Migration into Central AfricaGhana-Tocrur-Kuku-Wangara-Ulil-Eastern Africa-Travels of Ibn Batuta-Description by Leo Africanus ................. 40

\section{CHAPTER IV.}

PORTUGUESE DISCOVERIES.

Rise of the Spirit of Discovery-Voyages along the Western Coast-The Senegal-Prince Bemoy-Discovery of the Congo-Numerous Missionaries sent out-Superstitions of the Natives.................47

\section{CHAPTER V.}

EARLY ENGLISH DISCOVERIES.

Decline of Portuguese maritime Power-Company formed in England to explore the Gambia-Richard Thompson-His Death-Jobson's Voyage up the Gambia-Manners of the Native Africans-VermuydenStibbs

\section{CHAPTER VI.}

\section{FRENCH DISCOVERIES.}

French Settlement on the Senegal-Jannequin's Voyage-Voyages of Brue up the Senegal-Bambouk; Gold Mines-Saugnier-Gumtrade..........................................67 
CHAPTER VII.

EARLY PROCEEDINGS OF THE AFRICAN ASSOCIATON.

Ledyard-Lucas-Information respecting the Interior-Houghton-His

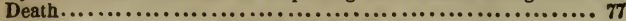

\section{CHAPTER VIII.}

PARE'S FIRST JNURNEY.

Park undertakes to explore Africa-Departure-IIl Treatment at Bondou and Joag-Kooniakary-Captivity among the Moors-Escape -The Niger-Sego-Sansanding-Silla-Obliged to return-Various Misfortunes-Distressed State-Finds Relief at Kamalia-Arrival in England $\ldots \ldots \ldots \ldots \ldots \ldots \ldots \ldots \ldots \ldots \ldots \ldots \ldots \ldots \ldots \ldots \ldots, 83$

CHAPTER IX.

PARK'S SECOND JOURNEY.

Views under which he was sent out-Departure-Overtaken by the Rainy Season-Great Sickness and Distress-Embarks on the NigerNegotiations with the King of Bambarra-Obtains Permission to build a Vessel-Sansanding-Sets sail-Accounts of his Death........ 100

CHAPTER $X$.

VARIUUS TRAVELLERS.

Horneman-Nicholls-Roentgen-Adams-Riley . 108

\section{CHAPTER XI.}

GOVERNMENT EXPEDITIONS.

Great Expedition planned inder Tuckey and Peddie-Captain Tuckey reaches the Congo-Difficulties encountered-Great Sickness-Disastrous Issue-Major Peddie arrives at Kakundy-His Death-Captain Campbell advances into the Foulah Territory-Obliged to return-His Death-Gray-Laing-Ritchie and Lyon-Death of Ritchie...... 121

\section{CHAPTER XII.}

DENHAM AND CLAPPERTON.

Arrangements with the Court of Tripoli- The Travellers arrive thereJourney to Mourzouk-Difficultics-Agreement with Boo KhalloomDeparture-The Desert-Tibboos and Tuaricks-Arrive at the Lake Tchad-The Yeou-Knuka-Visit to the Sheik-The Sultan-Description of Bornou-Denham's Excursion to Mandara-Great Range of Mountains-Disastrous Expedition-War against the Mungas-Excursion to Loggun-Expedition against the La Salas-BiddoomahsClapperton's Journey into Houssa-Appearance of that CountryKano-Sackatoo-Sultan Bello-Return of the Travellers........ 126

CHAPTER XIII.

CLAPPERTON'S SECOND JOCRNEY, \&C.

Objects of this Journey-Departure from Badagry-Death of Pearce and 
of Morrison-Kingdom of Yarriba-Eyeo-Kiama-Wawa-BoussaParticulars respecting Park-Nyffee-Koolfu-Zaria-Kano-Siege of Coonia-Violent Conduct of Sultan Bello-Sickness and Death of Clapperton at Sackatoo-His Servant Lander returns, partly by a new Route-Laing's Expedition-He reaches Timbuctoo-Assassinated-Caillié undertakes a Journey-Reaches Jenne-TimbuctooAroau-The Desert-Arrival at Tangier.................. 170

\section{CHAPTER XIV.}

WESTERN AFRICA.

General View of this Coast-Dahomey; Norris and M'Leod-Foota Jallo; Watt and Winterbottom-Ashantee; Embassies of Bowdich and Dupuis; War-Adams' Account of Benin and Waree....... 197

\section{CHAPTER XV.}

SOUTHERN AND EASTERN AFRICA.

The Cape-Settlement of the Dutch-Kolben-Hope, Sparrman, Le Vaillant-Barrow ; Caffres; Bosjesmans-Trutter and Sommerville-Dr. Cowan and his Party-Their Assassination-Lichtenstein-Campbell's (the Missionary) First and Second Journeys-Burchell-ThompsonInvasion of the Mantatees-Zoolas ....................... 207

\section{CHAPTER XVI.}

SOCIAL CONDITION OF AFRICA.

Distinction between Native and Foreign Tribes-Natives-Agriculture - Manufactures - Trade -Domestic Accommodations - Intellectual Character-Superstitions-War and Slavery-Some amiable Features-Forms of Government-Foreign Races-Mohammedan Converts-European Colonization-Cape of Good Hope-Albany District

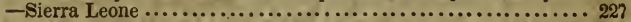

\section{CHAPTER XVII. \\ GEOLOGY OF AFRICA.}

Form and Situation of Africa-Its great Natural Regions or Divisions.1. Geology of the Atlas or Northern Region-Age of the Atlas Mountains. -2 , Geology of the Sahara Region-Subterranean Villages near Tripoli; in Spain and France-Tertiary Rocks of Benioleed-Soudan or Black Mountains-Petrified Wood in the Desert-Horrid Consequences of the Slave-trade-Human Skeletons in the Desert-Natron and Salt Lakes-Desert of Bilma-Sultan of Fezzan and a Slave-On what Formation does the Sand of the Desert rest?-Description of a Trona or Natron Lake-Fulgurite and native Meteoric Iron in tho Desert-Observations on the Sand of the Desert-Moving Pillars of Sand-Sand-wind-How the prevailing Winds affect the Sand of the Desert-What is the Geognostical Age of the Sahara? - 3. Geology of the Region to the South of the Sahara, and to the North of the Great Table-land-African Gold.-4. Geology of the Great Table-land of Africa-Geolngy of the Coast from Sierra Leone to Cape NegroCape of Good Hope District-Distribution of its Chains of Mountains, Plains and Valleys, or Kloofs-Description of the Karroo Plains- 
Gengnosy of the Peninsula of the Cape of Good Hope-The Lion's Rump-Lion's Head-Table Mountain-Devil's Peak-To what Class of Rocks do those of the Cape Peninsula belong ?-At what Period did the Cape Rocks rise above the Level of the Sea? - Vegetables incrusted with Calcareous Sand confounded with Coral, and adduced as a Proof of the very recent Emergence from the Ocean of the Lands supporting them-Geology of the Table-land, properly so called-Account of the Sibilo of the Africans-Geological Survey of the Karroo Ground recommended-Rivers-South African Lakes-South African Springs-Remarks on the Importance of a Knowledge of the Natural History and Chemical Composition of Springs-Geology of Caffraria, Natal, \&c. -Conclusion............................... 244

\section{CHAPTER XVIII.}

NATURAL HISTORY OF THE QUADRUPEDS OF AFRICA.

Introductory Observations - Orang-outang - Monkeys - Raboons-Lemurs-Galagos-Bats-Shrew-mise-Cape Mole - Tenrec - Ratel Otter-Jackals and Wild Dogs-Civets-Lion-Panther and Leopard -Lynxes-Squirrels-Marmots-Sand Mole-Gerboa-Rats and Mice -Dormice-Porcupines-Hares and Rabbits-Cape Ant-eater-Manis -Elephant-Rhinoceros-Ethiopian Hog-Hippopotamus-Zebra Quagga-Camel-Drnmedary-Red Deer-Giraffe-Antelopes of various kinds-Gnu-Cape Buffalo-Egyptian Goat and Sheep...... 290

\section{CHAPTER XIX.}

NATURAL HISTORY OF THE BIRDS OF AFRICA.

Introductory Observations-Vultures-Serpent-eater-Eagles-Hawks -Owls-Butcher-birds-Thrushes-Buntings-Colius-Beef-eatersRollers-Goat-suckers-Swallows-Hoopoes-Promerops-Creepers -Bee-eater-Kingfishers-Hornbills-Wondpeckers-Cuckons - Honey-guide-Parrots-Pogonias-Trogon-Musophaga-Touraco-Pigeons-Guinea Fowls-Quails-Partridges, \&c.-Ostrich-Bustards -Balearic Cranes-Flamingo-Gigantic Stork-Umber-Suipe and Woodcock-Sandpiper-Couvier-Plover-Penguin -Pelican-Plotus -Tern-Gull-Albatross-Cape Petrel-Spur-winged Goose-Mountain Goose-Egyptian Goose-Sheldrake-Musk-duck .......... 323

\section{CHAPTER XX.}

NATURAL HIBTORY OF THE REPTILES, FISHES, SHELLS, INSECTS, \&C. OF AFRICA.

Introductory Observations - Crocodiles - Lizards - Chameleon - Serpents - Frogs - General Observations on Fishes-Muræna-GobiusCotrus-Scorpæna-Zeus-Remora-Labrus - Mackarel - Surmullet -Flying Gurnard-Electric Silure-Salmon-Polypterus-Argentine -Flying-fish-Polyneme-African Herring-Carp-Mormyrus-Ray -Ostracion-Tetrodon-Pipe-fish - Fossil Fish - General Observations nn Shells-Various African Species - Remarks on the Distribution of Insects-Goliathus, \&c.-Paussus-Mantis-Locusts-Rutterfly Tribe - Bees-Scorpions-Centipedes-Zoophytes-Coral-SpongeGuinea Worm ......................................349 


\section{ENGRAVINGS.}

MAP of Africa.......................... To face the Titlepage.

Vianetre-Caravan in the Desert.

Group of Figures-Chief, Jillemen or Native Musicians, and Gree-

gree Man or Magician ........................... Page 63

Female Negro Dancer.............................. 77

Park's Routes .................................... 82

Tuarick on his Camel, with Male and Female Tibboo .......... 134

Denham and Clapperton's Routes....................... 137

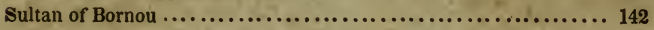

Fishing in the River Yeou............................. 145

Bornou Horseman, Kanemboo Spearman, and Munga Bowman.... 157

Timbuctoo according to Caillié .......................... 195

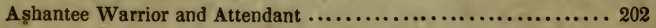

Queen of Lattakoo, Lattakoo Warrior, and two Bosjesman Hottentots............................................ 225

Negroes preparing the Manioc Root..................... 230

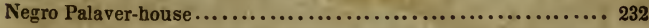

Group of African Animals-In front, in the centre, the Rhinoceros;

- to the right, the Hippopotamus and Orang-outang. In the centre background, the Giraffe ; - to the left, Antelopes and Zebra ...... 290 


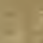

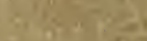

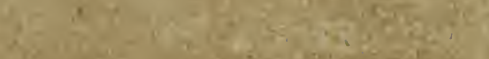

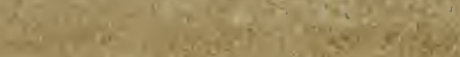

Ar

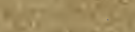

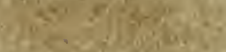

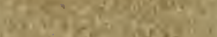

a

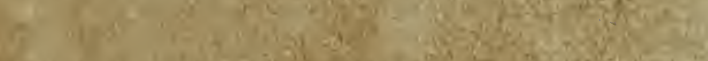

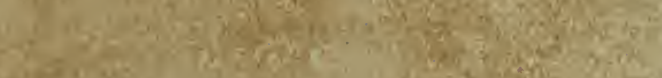

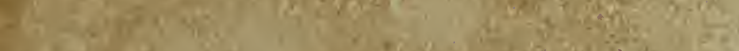

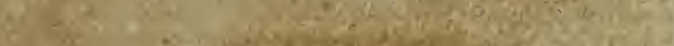

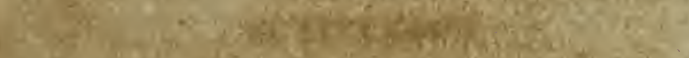

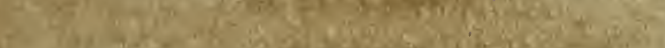

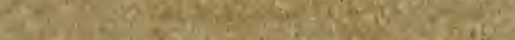

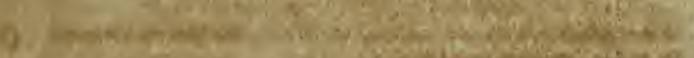

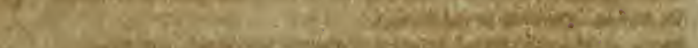

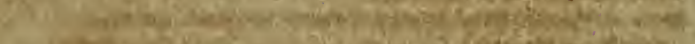

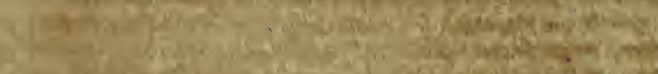

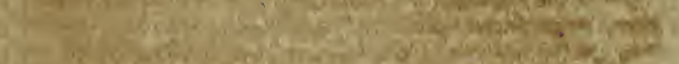

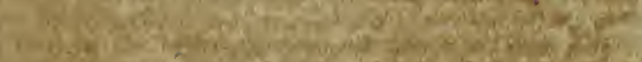

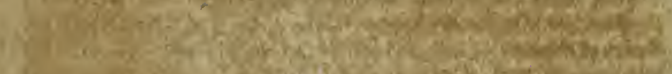

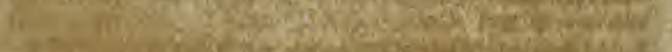
H.

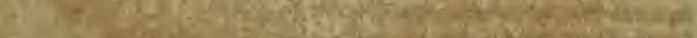

W.

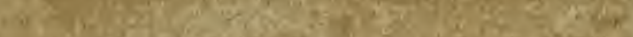

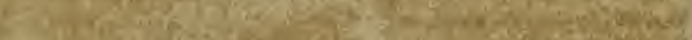

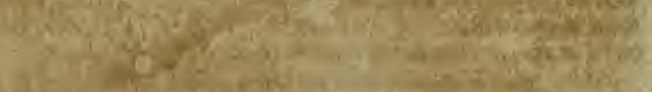
(Y) She

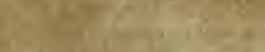

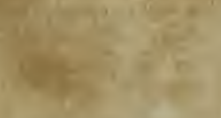

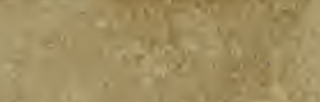

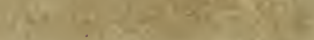




\section{DISCOVERY AND ADVENTURE}

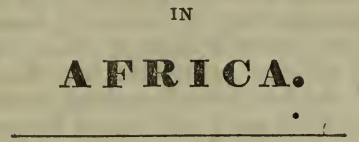

CHAPTER I.

General View of the Natural Features of Africa.

BEFORE following the career of adventure and discovery in Africa, and viewing its kingdoms and regions under their varied aspects, it may be interesting to take a rapid survey of this continent in its original state, as it came from the hands of nature. Though immense, and abounding even with the most striking and surprising contrasts, yet, on a general view, a certain uniformity, approaching almost to monotony, appears to pervade it. From one end to the other, dreary wastes of almost boundless extent are spread over its surface, alternating with bright intervals of the most luxuriant vegetation. These arid tracts also have their borders embellished by shrubs and flowers tinted with the most brilliant hues; while a profusion of animal life in all its forms distinguishes the more temperate latitudes.

-Africa, considered in relation to her place on the map, forms an extensive continent, situated nearly in the centre of the earth, and obstructing the great highway across the ocean. Her coasts form the chief barrier to a direct maritime intercourse between the distant extremities of the globe. To perform the vast circuit of her shores, and to round her stormy capes, has tried the courage and hardihood of the greatest navigators. Could Africa cease to exist, great facilities would be afforded to the communication between the other continents, and many new channels of commerce would be opened up. As she, however, 
has an existence likely to be coeval with theirs, our concern is with her actual condition, presenting as it does many peculiar claims to interest in the eyes of the philosopher and politician.

The physical peculiarities which distinguish Africa seem to depend chiefly on the circumstance that almost her whole territory is situated within the tropics. The other portions of the 'earth's surface which lie directly beneath the solar influence consist generally either of sea, or of narrow and insular lands, refreshed by breezes from the ocean. But the greatest breadth of Africa is under the immediate power and dominion of the sun; and most of her people see that great planet, in its annual progress from tropic to tropic, pass twice over their heads, and thus experience a repetition of its most intense and perpendicular rays. The highest blessings of this sublunary world, when carried beyond a certain limit, become its deadliest bane. That parent orb, which cheers and illumines the rest of the earth, glares on Africa with oppressive and malignant beam, blasting the face of nature, and covering her with barrenness and desolation. Sometimes it converts the soil into a naked desert, sometimes overspreads it with a noxious excess of animal and vegetable life. The soil, when not watered by copious rains or river inundations, is scorched and dried up till it is converted into a dreary waste. Hence it is, that in Africa plains of sand form a feature so truly alarming. The Great Desert, with the exception of the narrow valley of the Nile, reaches across the entire continent, exhibiting an expanse of burning surface, where for many days the traveller finds not a drop of water, nor sees the least vestige of animal or vegetable nature. He pursues his dreary route amid loose hills, continually shifting, and leaving no marks to guide his course. Every breeze is filled with dust, which enters the mouth and nostrils, and penetrates between the clothes and skin. Sometimes it drives along in clouds and whirlwinds, beneath which it was once thought that caravans and even armies had been buried; but it is now ascertained that the numerous bones which whiten the desert are merely those of travellers who have sunk under famine, thirst, and fatigue; and that the sand, which continually blows, has accumulated above them. Travellers over these tracts of shingle have been impressed with 
the idea of their being the bed of an ancient ocean. This is not the place to enter into a speculation on the formation of the earth. That every part of its surface lay once beneath the waters is sufficiently apparent; but there is at least no historical proof that Africa emerged later than other continents. The earliest records represent her deserts to have been as extensive as they are in our days, and to have pressed equally close upon the cultivated belt along the northern coast. In general, all regions between the tropics, when not copiously watered, moulder into sand, alternating with a hard and impenetrable stratum of clay. The central wastes of Asia, those of Arabia and of Sindetic Hindostan, though inferior to those of Africa, are yet of similar character, and of immense extent.

In order to obviate the extreme effects of the tropical sun, which produces a desolation so dreadful, Nature has provided suitable remedies. Every country under this latitude has its rainy season, when, amid the blaze of lightnings and the noise of thunders rending the sky, heaven seems to open all her windows to pour an unbroken flood upon the earth. The ground is covered as with a deluge, and the dry beds of the rivulets are converted into torrents; yet so intense are the sun's rays, that the moisture thus lavished upon the surface is quickly dried up. Great rivers, which, swollen by the rains, overflow their banks and lay the surrounding country under water, or at least afford the means of artificial inundation, are the principal source of that luxuriant fertility, that mighty growth of vegetable forms, which singularly characterize the tropical climates. It is to the waters which descend from the lofty precipices and eternal snows of the Himmaleh, that the plains of Hindostan and China owe their amazing fruitfulness. Africa, too, has elevated mountain-chains, which give rise to several rivers of great magnitude and most fertilizing influence. Atlas, along its northern border, presents even in so hot a climate pinnacles wrapped in everlasting snow. Still more extensive is that central range, which, amid its various local names, is most generally known under the poetical appellation of "The Mountains of the Moon." Yet these chains, besides being not altogether so gigantic as those of the other continents, labour under the peculiar disadvantage of extending across the breadth only of Africa. The Andes and tho 
Himmaleh, those stupendous heights of America and Asia, as they traverse these continents in the direction of their length, cover a much greater surface, and thus create fertility in the more limited plains which intervene between the mountains and the ocean. But the largest of the African rivers, directing their course through a vast extent of low land, reach the sea only by a very circuitous course. Several of them, too, diffusing their waters into lakes or marshes, expire in the very heart of the continent. The result is, that the enormous breadth of the Sahara, or Great Desert, is scarcely irrigated even by a streamlet. It depends entirely on the periodical rains; and these sink into the sandy and porous surface, till being arrested at the depth of eight or ten feet, they form that "sea under ground" which has been traced over a large portion of the waste.

Vegetable life, in consequence of this absence of moisture, is scantily diffused over a great extent of the continent. In the heart of the mountains, however, and in the kingdoms along their border, the soil is most profusely watered, and, under the influence of a tropical sun, produces, perhaps, beyond any other part of the world, that luxuriant growth and those gigantic vegetable forms, which distinguish the equatorial regions. The baobab, or great calabash, appears to be the most enormous tree on the face of the earth. Adanson assures us, that the circumference in some cases is equal to thirteen fathoms, as measured by his arms clasped round the trunk, that is, varying from seventy-four to seventy-seven feet. Branches extending horizontally from the trunk, each equal to a large tree, make the baobab a forest as it were in itself. The mangrove, too, which rises on the borders of rivers, or inundated spots, diffuses itself in a manner truly remarkable. The branches, dropping down upon the watery bank, strike root and grow ; hence the original plant, spreading farther and farther, forms over the stream a species of natural arcade. These mighty trees do not stand alone, but have their interstices filled up by numberless shrubs, canes, creeping and parasitical plants, which intersect and entwine with each other till they form a thick and impenetrable mass of underwood. To cut even a narrow path through these dense forests is a laborious process; and as shoots are continually protruding inwards on each side, the track, without constant 
travelling, and the diligent use of the axe, soon becomes impassable.

As we approach the confines of the Desert these giants of the wood disappear, and vegetation presents a different and more pleasing aspect. It exhibits now the light and gay form of the acacia, whole forests of which rise amid the sand, distilling those rich gums that afford an important material of African commerce. The lotus, a celebrated and classical shrub, the tamarisk, and other small and elegant trees, afford agreeable and nutritive berries, which constitute the food of several nations. Various flowering shrubs of the most delicate tints, rising in wild and spontaneous beauty, embellish the precincts of the waste. Thus the Desert, in its first approaches, and before vegetable life begins to expire, does not assume its sternest character, but wears even a peculiarly pleasing and smiling aspect.

The animal world* in Africa changes equally its nature as it passes from one to another of these opposite regions. In those plains which are inundated by the great rivers, it multiplies at an extraordinary rate, and often assumes huge and répulsive forms. Throughout all this continent the wild tribes exist in large and formidable numbers, and there is scarcely a tract which they do not either hold in full possession, or fiercely dispute with man. Even the most denselypeopled countries border on wide forests and wastes, whose savage tenants find their prey occasionally in man himself, as well as in the domestic animals which surround him; and when the scent of human slaughter is wafted on the breeze, bands of hungry monsters hasten from every side to the feast of blood. These ferocious creatures hold, indeed, so commanding a position, that the colonist scarcely makes any attempt to extirpate them, or even to keep down their numbers. He wages against them only a defensive war, and employs his courage and skill chiefly in hunting the elephant, the antelope, and other peaceful species, by whose spoil he may be enriched.

The lion, that king of the desert, that mightiest among the tribes which have the wilderness for their abode, abounds in Africa, and causes all her forests to re-echo his midnight

* In the present chapter we allude only to a few of the more conspicuous and peculiar characteristics of African zoolngy. The subject is treated of at greater length in a subsequent part of this volume. 
roar. Yet both his courage and fierceness have, it is said, been overrated; and the man who can undauntedly face him, or evade his first dreadful spring, rarely falls his victim. Wider ravages are committed by the hyena, not the strongest, but the most ferocious and untameable of all the beasts of prey. These creatures, by moving in numerous bands, achieve what is beyond the single strength of the greater animals ; they burst with mighty inroad into the cities, and have even carried by storm fortified enclosures. The elephant roams in vast herds through the densely-wooded tracts of the interior, disputing with the lion the rank of king of the lower creation; matchless in bulk and strength, yet tranquil, majestic, peaceful, led in troops under the guidance of the most ancient of the number, having a social and almost moral existence. He attacks neither man nor beast. The human being is more frequently the aggressor, not only with the view of protecting the fruits of the earth, but also in order to obtain the bony substance composing his tusks, which, under the name of ivory, forms one of the most valued articles of African trade. The prodigious strength of the elephant, his almost impenetrable hidè, his rapid though unwieldy movements, render him a most perilous object of attack, even to the boldest hunters; so that pits and snares of various kinds are the usual modes by which his capture is effected. Instead of the tiger, Africa has the leopard and the panther; belonging, however, only to certain of its districts.

In the large and broad rivers of Africa, and through the immense forests which overshadow them, a race of amphibious animals of monstrous form and size display their unwieldy figures. The rhinoceros, though not strictly amphibious, slowly traverses marshes and swampy grounds, and almost equals the elephant in strength and defensive powers, but wants his stature, his dignity, and his wisdom. The single or double horn with which he defends himself is an article of commerce in the East, though not valued in Europe. A still huger shape is that of the hippopotamus, or river-horse, fitted alike to stalk on land, to march along the bottom of the waters, or to swim on their surface. He is slow, ponderous, gentle; yet when annoyed, either by design or accident, his wrath is terrible; he rushes up from his watery retreat, and by merely striking with his enor- 
mous tusks, can overset or sink a loaded canoe. But the most dreaded of all the inhabitants of the African rivers is the crocodile, the largest and fiercest of the lizard tribe. He lies like a log upon the waters watching for his prey, attacking men, and even the strongest animals, which, however, engage with him in obstinate and deadly encounters.

We have not yet done with all the monstrous and prodigious forms which Africa generates. She swarms with the serpent brood, which spread terror, some by their deadly poison, others by their mere bulk and strergth. In this last respect the African serpents have struck the world with amazement; ancient history records that whole provinces were overrun by them, and that one, after disputing the passage of a river with a Roman army, was destroyed only by the use of a battering engine.

Emerging from these dank regions, where the earth, under the united influence of heat and moisture, teems with such a noxious superabundance of life, we approach the Desert. Here a change takes place equally singular and pleasing as in the vegetable world. Only light, airy, and fantastic forms trip along the sandy border; creatures innocent, gentle, and beautiful, - the antelope of twenty different species, all swift, with bright eyes, erect, and usually elegant figures, preying neither on men nor animals, but pursued by all on account of the delicate food which they afford. Here, too, roams the zebra, with its finely-striped skin wrapped around it like a robe of rich cloth; and the camelopard, the tallest and most remarkable of animal forms, with its long fore-legs and high-stretching neck of singular and fantastic beauty, crops the leaves of the African forest. Though a rare species, he is seen occasionally straying over a great proportion of that continent.

Nature, sporting as it would seem in the production of extraordinary objects, has filled Africa with a wonderful multitude of those animals which bear the closest alliance to " the human form divine." The orang-outang appears to constitute the link between man and the lower orders of living things. Standing erect, without a tail, with flat face, and arms of not greatly disproportioned length, it displays in every particular a deformed resemblance to the lord of the creation. It seems even to make a nearer approach than any other animal to the exercise of reason. It 
has been taught to make its own bed, to sit at table, to eat with a knife and fork, and to pour out tea. M. Degrandpré mentions one kept on board a French vessel, which lighted and kept the oven at a due temperature, put in the bread at a given signal, and even assisted in drawing the ropes. There was a strong suspicion among the sailors that it would have spoken, but for the fear of being put to harder work. The baboons, again, are a large, shapeless, brutal species, ugly and disgusting in their appearance, yet not without some kind of union and polity. The monkey tribe, now familiar in Europe, and attracting attention by their playful movements, fill with sportive cries all the forests of tropical Africa.

The insect race, which in our climate is generally harmless, presents here many singular and even formidable characteristics. The flying tribes, in particular, through the action of the sun on the swampy forests, rise up in terrible and destructive numbers. They fill the air and darken the sky; they annihilate the labour of nations; they drive even armies before them. The locust, when its bands issue in close and dark array from the depths of the Desert, commits ravages surpassing those of the most ferocious wild beasts, or even the more desolating career of human warfare. In vain do the despairing inhabitants seek with fire and other means to arrest their progress; the dense and irresistible mass continues to move onward, and soon baffles every attempt to check its course. Whole provinces, which at at their entrance are covered with rich harvests and brilliant verdure, are left without a leaf or a blade. Even when destroyed by famine or tempest, they cover immense tracts, exhaling the most noxious stench. Yet they may be used as food, and are even relished by certain native tribes. The mosquito and its allies do not spread such a fearful desolation; yet by their poisoned and tormenting stings they render life miserable, and not very unfrequently lead to its extinction. Even a swarm of wild bees, in the solitary woods of Western Africa, has put a whole caravan to flight, wounding severely some of its members. But perhaps the most extraordinary of all the insect races are the termites, or white ants, which display on a greater scale the arts and social organization for which their species have been so famed in Europe. They cover the plains with their 
conical huts from ten to twelve feet in height; they are regularly distributed into labourers and soldiers, with others holding the rank of king and queen. This latter personage, when she is about to add to the numbers of the tribe, presents a most extraordinary spectacle, being then swelled to many times the amount of her natural dimensions; and when the critical period arrives, instead of a progeny of two or three, she produces as many thousands. These ants are far from being of the same harmless description as the corresponding insects of this quarter of the world. On finding their way into a house, they dewour every thing, clothes, furniture, food, not even it is said sparing the inmates, who are compelled to make a speedy retreat.

Such are the evils to which the people of this continent are perpetually exposed from the lower creation; and yet they experience in full force the truth of the pathetic lamentation of the poet, that "man is to man the surest, deadliest foe." Africa from the earliest ages has been the most conspicuous theatre of crime and of wrong; where social life has lost the traces of primitive simplicity, without rising to order, principle, or refinement; where fraud and violence are formed into national systems, and man trembles at the sight of his fellow-man. For centuries this continent has seen thousands of her unfortunate children dragged in chains over its deserts and across the ocean, to spend their lives in foreign anddistant bondage. Superstition, tyranny, anarchy, and the opposing interests of numberless petty states, maintain a constant and destructive warfare in this suffering portion of the earth.

Nevertheless, compelled as we have thus been to describe the ills of Africa, we should err very widely did we represent her as pervaded by one deep monotonous gloom. Throughout the picture there are bright lights interspersed, which shine more conspicuously from the vast blanks and deep shadows with which they are surrounded. In the heart of the most dreary and sandy wastes, there emerges many a little oasis, or verdant islet, which to the wanderer of the desert appears almost an earthly paradise. These spots have been painted in colours that belong not to the imperfect abodes of earth; as gardens of the gods, fairyseats, islands destined to be the future mansions of the blessed. In like manner, in the bosom of its wildest woods 
and mountains, there lurk, in many an unsuspected retreat, scenes of the most soft and pastoral beauty. Even amid its moral darkness there shine forth virtues which would do honour to human society in its most refined and exalted state. A tender flow of domestic affection generally pervades African society. Signal displays, too, have been made of the most generous hospitality; and travellers, who were on the point of perishing, have been befriended and saved by absolute strangers, and even by enemies. These varieties of nature and of character, these alternations of wildness and of beauty, of lawless violence and of the most generous kindness, render the progress of the traveller through this continent more interesting and eventful, more diversified by striking scenes and incidents than in any other quarter of the globe.

\section{CHAPTER II.}

On the Knowledge of Africa among the Ancients.

Africs, so far as it extends along the Mediterranean, was not only well known to the nations of antiquity, but constituted an integral part of their political and social system. This coast forms, indeed, only a comparatively small portion of that great continent; but while the sphere of civilization and the geographical knowledge of the Greeks were nearly comprised wjthin the circuit of the Mediterranean shores, Northern Africa held in their view no inconsiderable importance. This region, which is now covered with thick darkness, and left so far behind in all the arts and attainments which exalt and adorn human nature, had at that early period taken the lead in these very particulars of all other nations. It included Egypt and Carthage, which, as the first seats of government and commerce, were the admiration of the ancient world. In the patriarchal ages, when Scripture history represents the Mesopotamian Plain, the scene of the future empires of Babylon and Assyria, as little more.than a wide and open common, Egypt 
appears regularly organized, and forming a great and powerful kingdom; and wh:n Greece was under the tumultuary sway of a multitude of petty chieftains, Homer already celebrates the hundred gates of Thebes, and the mighty hosts which in warlike array issued from them to battle. Egypt was illustrious also among the ancients as producing the first elements of learning and abstract science,-the first approach to alphabetical writing by hieroglyphic emblems, - the first great works in sculpture, painting, and architecture; and travellers even now find that country covered with magnificent monuments, erected at an era when the faintest dawn of science had not yet illumined the regions of Europe. While Egypt was thus pre-eminent in science and art, Carthage equally excelled in commerce and in the wealth which it produces; by means of which she rose to such a degree of power as enabled her to hold long suspended between herself and Rome the scales of universal empire. In that grand struggle Carthage sunk amid a blaze of expiring glory; while Egypt, after having passed through many ages of alternate splendour and slavery, was also at length included in the extended dominion of Rome Yet, though all Mediterranean Africa thus merged into a province of the Roman world, it was still an opulent and enlightened one; boasting equally with others its sages, its saints, its heads and fathers of the church; and exhibiting Alexandria and Carthage on a footing with the greatest cities of the empire.

While, however, the region along the Nile and the Mediterranean was thus not only well known, but formed a regular part of the ancient civilized world, the progress of science did not extend beyond the tract bordering on the coast and the river. After proceeding a few journeys into the interior, the traveller found himself among wild and wandering tribes, who exhibited human nature under its rudest and most repulsive forms. On his advancing somewhat farther still, there appeared a barrier vast and awful -endless plains of moving sand, without a shrub, a blade of grass, or a single object by which human life could be cheered or supported. This appalling boundary, which stopped the victorious career of Cambyses and of Alexander, arrested much more easily every attempt at civilization and settlement. It secured to the wild and roaming tribes 
of the Desert the undisturbed possession of those insulated spots of verdure, which were' scattered at intervals amid the desolation of the interior waste.

Meantime, although these causes prevented the civilization, and even the knowledge of the ancients, from ever penetrating deeply beyond the Mediterranean border, yet between it and the measureless Desert there intervened a wide tract of alternate rock, valley, and plain, presenting a varied, and often a picturesque landscape. This region, intermediate between the known and the unknown, between civilized and savage existence, excited in a somewhat peculiar degree the curiosity of the ancients; to whom, however, it always appeared dimly as through a cloud, and tinged with a certain fabulous and poetical colouring.

Herodotus, the earliest and most interesting of Greek historians, when endeavouring to collect information respecting the whole of the known world, was obliged, in the absence of written records, to have recourse to travelling; and his narrative is almost entirely the record of what he saw and heard during his various peregrinations. By means of a long stay in Egypt, and an intimate communication, with the native priests, he learned much that was accurate, as well as somewhat that was incorrect and exaggerated, respecting the wide region which extends from the Nile to the Atlantic. He justly describes it as much inferior in fertility to the cultivated parts of Europe and Asia, and suffering severely from drought; yet there were a few spots, as Cinyps and the high tracts of Cyrene, which being finely irrigated, might stand a comparison with the richest portions of the globe. Generally, however, in quitting the northern coast, which he terms the forehead of Africa, the country became more and more arid. Hills of salt arose, out of which the natives constructed their hoises, without any fear of their melting beneath a shower, in a region where rain was unknown. The land became almost a desert, and was filled with such multitudes of wild beasts, as to be considered their proper inheritance, and scarcely disputed with them by the human race. Farther to the south, the soil no longer afforded food even to these wild tenants; there was not the trunk of a tree nor a drop of water; total silence and desolation reigned. Such is the general picture which Herodotus draws of this northern boundary of the great 
African desert, which must be acknowledged to be at once accurate and just.

In the tract westward from Egypt, behind the great "African forehead," the first object was the celebrated and sacred shrine of Ammon, dedicated to the Theban Jove, and to which the Greeks ascribed a higher prophetic power than even to their own Delphic Oracle. This temple, situated in the midst of almost inaccessible deserts, was distinguished for a fountain, which, warm at midnight, became always colder and colder till noon. Ten days' journey beyond Ammon lay Egila, occupied by the Nasamones, a numerous people, who in winter fed their flocks on the seacoast, and in summer repaired to collect and store up the dates here growing on extensive forests of palm-trees. To this people are ascribed various singular customs, among which was their mode of foreseeing the future by laying themselves to sleep on the tombs of their ancestors, watching the dreams which arose in this position, and treasuring them up as oracles. Bordering upon them had formerly been the Psylli, famous for the charming of serpents, an art not yet wholly lost in this region; but that tribe, suffering once under a severe drought, had been so ill informed as to proceed southward in hope of finding water, where, being involved in those vast and burning deserts, they entirely perished, and their place was taken by the Nasamones. Beyond them, the Macae inhabited a beautiful region watered by the river Cinyps, on whose bank rose "the hill of the Graces," covered with a profusion of the finest foliage. Such is still the gay and brilliant aspect which the neighbourhood of Bengazi presents. To the south of the $\mathrm{Na}$ samones, in a region almost resigned to wild beasts, the Garamantes inhabited an extensive valley, now called Fezzan. They are represented under characters of which the present natives retain no trace,-as a solitary and timid people, shunning the intercourse and society of men, destitute of arms, and not even attempting to defend themselves against foreign aggression.

After the Gindanes and the Lotophagi, who ate the lotus and made wine from its fruit, came the Machlyes and the Auses, dwelling round the lake of Tritonis; the scene of the reported birth and oracle of Minerva, with which were connected many celebrated fables of ancient mythology. It 
is with reluctance that reference is here made to what the venerable father of history has related respecting the conduct of the young ladies in this region; and we should hope that scandal on this subject may have been as busy in the coteries of Sais and of On, as in some modern circles. Can it be believed, that among the Gindanes they should form threads of skin, and tie a knot on it for every lover who had sought and won their favour, measuring their importance by the number of these knots; or is it probable that, at the marriage of the Nasamones, the favour of the bride should have been shared by all the guests equally with the husband? Nor is there much to admire in the annual festival celebrated by the virgins of the Auses, when their fair hands were employed in throwing stones against each other with such fury, that several were commonly left dead on the spot. The fate of these sufferers was peculiarly hard, since it was supposed to justify the most unfarourable suspicions respecting their previous life. After all, this rough sport of the Libyan belles is not much ruder than one which we shall find still practised among the most distinguished dames of Bornou.

Proceeding farther westward, Herodotus finds a tribe of the Auses, called Maxyes, who cultivated the ground; and he is now on the border of the Carthaginian territory, of which, for reasons that Major Rennel cannot fully comprehend, he forbears to treat. He follows the direction of the interior, from the Garamantes, beyond whom were Ethiopians dwelling in caves, and running so swiftly that the former people were obliged to hunt them in chariots, - a proceeding very unsuitable to the meek character elsewhere ascribed to them, and which, we fear, may have been practised with the evil intent of carrying off these poor victims as slaves. Our author comes next to the Atlantes, and relates several things which with better knowledge he would probably have omitted. He pretends, for example, that none of them bear proper names; that they neither eat animal food nor dream dreams; and, what is not quite so improbable, that on seeing the sun rise, they pour reproaches and execrations on him for the manner in which he burns and destroys their land. Behind them rises the long and lofty range of Atlas, whose head is said to remain for ever invisible and wrapped in clouds, and which the natives believe 
to be the pillar of heaven,- a creed adopted, or perhaps invented, by the Greeks and Romans. Herodotus here stops, frankly owning that his information did not enable him to go farther. The only other accounts which had reached him respected a nation beyond the Pillars of Hercules, with whom the Carthaginians carried on trade in a very peculiar manner. This wild and timid race would not approach or hold parley with the strangers, who, on drawing near to the shore, kindled a fire, uttered loud cries, and laid on the sand a certain quantity of goods. The natives, hearing them, and seeing the smoke, came down, surveyed the deposite, placed beside it a certain portion of gold, the precious article of their traffic, and withdrew. The Carthaginians approached to examine the tender thus made, and, according to their estimate of its value, either carried away the gold or left the whole untouched; in which last case, the natives understood that more of the precious metal was expected. Thus the parties went backwards and forwards till the exchange was adjusted.

If the accounts given by Herodotus of this western region be tinctured with fable the narrative of Diodorus shows still more that the ancients had made it one of the grand theatres of their mythology. To it they refer the ancient and early reign of Saturn, under the appellation of Ouranus, or Heaven; the birth of Jupiter, and his nursing by Amalthæa; the impious race of the Titans, and their wars with the sky; Cybele, with her do:ing love for Atys, and frantic grief for his fate. Dioderus represents the Atlantic people as claiming these objects for tiemselves; but it seems much more probable that the warm imagination of the Greeks, attracted by the mysterious grandeur of the region, transported thither the creations of their own fancy. Our author, however, makes a positive averment as to the existence of a race of Amazons there, still more warlike and formidable than those on the banks of the Thermodon. They did not, like these last, positively exterminate or expel the male sex from their confines; but, reserving to themselves all the high cares of war and government, employed their lords in keeping the house, tending the children, and performing all the functions which are elsewhere exclusively assigned to females. As soon as the wife had gone through the necessary trouble of bearing a child, she handed 
it to the husband to be nursed, and immediately resumed her own high and arduous occupations. These gallant viragoes, it is said, not only ravaged all this part of Africa, but passed the Isthmus of Suez, and carried their victorious arms into Syria and Asia Minor. What foundation there may be in fact for this story of the Western Amazons, it is not easy to conjecture; but the Tuaricks, a numerous native race still found in those regions, treat their females with greater respect and allow them more liberty than is usually granted among their neighbours. These were not the only fierce and warlike females who spread terror through Africa. Diodorus places here the Gorgons, who caused death by the mere hideousness of their aspect, and the serpents hissing in the hair of Medusa. Yet, amid all these terrible fables, he gives a just description of the back settlements of Northern Africa; representing them as thinly inhabited by wandering tribes, as bounded by an extensive uniform plain resembling the ocean. covered with piles of sand of which the termination was unknown, and which, instead of any object that could cheer the eye or refresh the senses, swarmed with serpents of huge form and magnitude, that inflicted instant death on the unwary traveller. These reptiles were even reported to have once invaded Egypt, and driven before them a cruwd of its terrified inhabitants.

Strabo, who wrote after the Roman sway was fully establisked over Africa, gives a much more sober report of its western regions. Extending his ${ }^{\circ}$ view beyond the Atlas, he describes the Mauri, peopling a rich territory on the Atlantic coast capable of yielding the most copious harvests; but nothing could wean the nation from the wandering life in which they delighted, moving continually with their tents from place to place, wrapped in the skins of wild beasts, riding without saddle, and often without bridle, on small, swift, active horses. He represents them as fighting with sword and spear, not with the poisoned arrows imputed to them by Horace, which, however, are really used at present in Central Africa. Eastward, around Carthage, he finds the Massæsyli, who followed once the same wandering life, and were called Nomades or Numidians; but Masinissa had already inured them to the practice of agriculture, and to some of the refinements of polished life. Carthage at its first sub- 
jection was razed to the ground and left long desolate; but the Romans, at length attracted by the view of the fine region which surrounds it, sent thither a colony, who soon elevated it to its former rank as the greatest city of Africa.

Another territory, of which the ancients had considerable knowledge, was that which extended upwards along the Nile, the immediate borders of which have always been not only habitable but fertile. Nothing astonished them more than to see this great river, which, after flowing through a region where there did not fall a drop of rąin, and where it was not fed by a single rivulet, began to swell at a certain season, rose always higher and higher, till at length it overflowed its banks, and spread like a sea over Lower Egypt. Some of the hypotheses formed to account for this inundation deserve to be noticed. The most prevalent opinion ascribed it to the Etesian winds blowing from the north periodically, and so violently, that the waters of the Nile, thereby prevented from reaching the sea, necessarily spread over the land; but Diodorus clearly shows, besides the reason being itself insufficient, that there was no correspondence in the periods; observing also, that the Etesian winds blew up many other rivers without producing this effect. The philosophers of Memphis, it. seems, followed even by Mela, the great Latin geographer, surmised that the unknown and inaccessible fountains of the Nile lay on the opposite side of the globe, where during our summer it was winter; consequently, the greatest rains then fell, and the swollen waters, flowing across the whole breadth of the torrid zone, acquired that soft and mellow taste which made them so agreeable. But the most singular hypothesis is that of Ephorus, who thought that Egypt is full of gaps or chinks which in winter absorb the water, but sweat it out under the influence of the summer heat. Diodorus takes superfluous pains to show that this theory, so absurd in itself, had no correspondence with the facts of the case. The real cause, arising from the rains which fall on the high mountains in the interior and tropical regions, was mentioned and strongly supported by Agatharchides, who wrote a learned work on the Red Sea; which, however, was far from attaining the favourable reception that it merited.

The name of Ethiopia was very generally applied by the ancients to the south of Africa, and even of Arabia, and C 2 
generally to all countries inhabited by black people. The region, however, which extends for several hundred miles along the Nile above Egypt, formed the ancient Ethiopia, a sacred realm, in which the priests placed the most revered objects of their mythology. Here Jove repaired to hold his annual festival; and here was spread the table of the sun, which, when exposed to the rays of that great luminary, was believed of its own accord to take fire and be consumed. Hence, according to some, Egypt derived all the sciences and arts which rendered her illustrious in that early age. Diodorus even asserts that the learned language of Egypt was the same spoken by the vulgar in Ethiopia; but we should much rather believe with Herodotus, that the latter country derived from Egypt all which she possessed of art and civilization. The sovereigns of Ethiopia are said to have received a wild and peculiàr homage, in being attended to the tomb by a number of their wives, courtiers, and servants, all eagerly canvassing for this honour,-a practice of savage life still extensively prevalent in pagan Africa. According to Diodorus, this veneration was carried to so singular a pitch, that if the king lost a leg or an arm, each of his courtiers presently severed from himself the same member. The priests, however, whose influence in this realm of superstition was always paramount, appear at one time to have become quite supreme; reducing the sovereign to a state of entire dependence. Lastly, it may be inferred, both from classic and sacred writers, that Ethiopia, in the first century, was governed by a female monarch, who appears to have borne the hereditary name of Candace.

The Greeks settled in Egypt, especially during the wise and able government of the Ptolemies, carried on a considerable navigation along the eastern coast of the Red Sea, which, as they held the continent to be bounded by the Nile, they accounted scarcely African; but upon this subject we must follow modern ideas. Ptolemy Euergetes seems to have conquered part of Abyssinia, forming it into a kingdom, of which Axum was the capital; and fine remains of Grecian architecture still attest the fact of this city having been a great and civilized metropolis. Every ancient description, however, represents the native inhabitants of these shores as existing in a state of the most extreme barbarity and wretchedness. They are classed by 
Diodorus and Strabo, according to the miserable food on which they usually subsisted; some as eaters of fish, of elephants, and of turtles; while others are said to have fed on locusts, on roots, and even on the tender branches of trees. Many sought shelter also in places which had no regular claim to be considered as human habitations. These were either cavities dug out of the rock, with an opening to the north for coolness, or they were formed by twisting together the branches of several large shrubs, and constructing thus a species of shady arbour; while some tribes, still more forlorn, merely climbed the trees to seek safety and shelter among the branches. These representations were once deemed fabulous, and might still have been thought so, had not Bruce and other modern travellers proved the existence of similar rudeness among the Shangalla and other tribes that border on Abyssinia.

'The districts now surveyed form the whole of Africa respecting which the Greeks had obtained any precise and determinate knowledge. It comprised a wide extent of shore, but extended a very short distance inland; being bounded on each side by two unknown coasts, which stretched so far that it was not possible to conjecture their termination. Two tempestuous oceans, a desert the most dreary on the face of the earth, and infested by multitudes of huge and ferocious animals, were the barriers that hemmed in so closely the ancient settlers, and could scarcely in any instance be passed with impunity. Yet the principle of curiosity cannot be extinguished in the human breast, and is even rendered more ardent by the greatest obstacles. To lift up a portion of that veil within which the vast mysteries of unknown Libya were shrouded, appeared an achievement rivalling the glories of conquest, and promised to confer immortal renown. The most active and adventurous spirits accordingly, who sought to acquire celebrity by exploring the earth, looked to Africa as affording the grandest theatre of fame and adventure.

Two expeditions of discovery, the earliest known, and perhaps that ever existed, are related by Herodotus. One of the most illustrious of the native kings of Egypt was Necho, whose name ranks second only to that of Sesostris, and who lived about two hundred years before the historian. The habits and prejudices of the ancient Egyptians 
were unfarourable to maritime enterprises; yet Necho, endowed with the spirit of a great man, which raised him superior to the age in which he lived, eagerly sought the solution of the grand mystery that involved the form and termination of Africa. He was obliged to employ, not native, but Phœnician navigators, of whose proceedings $\mathrm{He}$ rodotus received an account from the Egyptian priests. Proceeding down the Red Sea, they entered the Indian Ocean; and in a voyage of three years made the complete circuit of the continent, passing through the Pillars of Hercules (Straits of Gibraltar), and up the Mediterranean to Egypt. 'They related, that in the course of this very long voyage they had repeatedly drawn their boats on land, sowed grain in a favourable place and season, waited till the crop grew and ripened under the influence of a tropical heat, then reaped it, and continued their progress. They added, that in passing the most southern coast of Africa, they were surprised by observing the sun on their right hand, - a statement which the historian himself rejects as impossible. Such is all the account transmitted to us of this extraordinary voyage, which has given rise to a learned and voluminous controversy. Rennel in his Geography of Herodotus, Vincent in his Periplus of the Erythrean Sea, and Gosselin in his Geography of the Ancients, have exhausted almost every possible argument; the first in its favour, the two latter to prove that it never did or could take place. To these last it appears impossible that ancient mariners, with their slender resources, creeping in little row-galleys along the coast, steering wilhout the aid of the compass, and unable to venture to any distance from land, could have performed so immense a circuit. All antiquity, they observe, continued to grope in doubt and darkness respecting the form of Africa, which was only fully established several thousand years afterward by the expedition of Gama. On the other side, Major Rennel urges, that, immense as this voyage was, it was entirely along a coast of which the navigators never required to lose sight even for a day ; that their small barks were well equipped, and better fitted than ours for coasting navigation ; and which, drawing very little water, could be kept quite close to the shore, and even be drawn on land, whenever an emergency made this step indispensable. The 
statement, that at the extremity of Africa they saw the sun on the right, that is, to the north of them, -a fact which causes Herodotus peremptorily to reject their report,affords the strongest confirmation of it to us, who know that to the south of the equator this must have really taken place, and that his unbelief arose entirely from ignorance of the real figure of the earth.

The other expedition had its origin in the country of the Nasamones, whom we have already mentioned as occupying the district southward of Cyrene. Five young men of distinction formed themselves into an African association, personally to explore what was still unknown in the vast interior of this continent. They passed first the region inhabited by man ; then that which was tenanted by wild beasts ; lastly, they reached the immeasurable sandy waste. Having laid in a good stock of water and provisions, they travelled many days partly in a western direction, and attained at length one of the oases or verdant islands which bespangle the desert. Here they saw trees laden with agreeable fruit, and had begun to pluck, when there suddenly appeared a band of little black men, who seized and carried them off as captives. They were led along vast lakes and marshes, to a town situated on a large river flowing from west to east, and inhabited by a nation all of the same size and colour with the strangers, and strongly addicted to the arts of necromancy. It is not said how or by what route they returned; but, since they supplied this relation, they must by some means have reached home. Herodotus concludes this great river to be the Nile flowing from the westward; while Major Rennel conceives it to be the Niger of Park, and the city to be Timbuctoo; but since the late discoveries of Denham and Clapperton, it has appeared more probable that the stream was the Yeou or river of Bornou. The distance from Cyrene thither is not so great; and nowhere but in the Tchad can we find those mighty lakes which make so prominent a figure in the narration. On the whole, it must appear truly wonderful that these efforts, made at so early an era, should have led to discoveries, respecting both the maritime outline and the interior of the continent, which Europeans could not regain for thousands of years, and one of which, at the present day, is still entirely new to us, 
The next expedition on record was made under less pleasing auspices. Sataspes, a Persian nobleman, had been condemned by Xerxes to crucifixion, on account of some crime of which he had been guilty; but his mother, by earnest entreaty, obtained a commutation of the sentence into one which she represented as still more severe, -that of sailing round Africa. Under this heavy necessity, Sataspes coasted along the Mediterranean, passed the western point of the continent, and began a southward course. But he who undertook to explore this vast country with no interest in the subject, buoyed up by no gay enthusiasm, and urged only by the fear of death behind, was ill prepared for achieving so mighty an enterprise. Sataspes sailed southward for a considerable space; but when he saw the Atlantic waves beating against the dreary shore of the Sahara, that scene of frequent and terrible shipwreck, it probably appeared to him that any ordinary form of death was preferable to the one which here menaced him. He returned, and presented himself before Xerxes, giving a doleful description of the hardships which he had encountered, declaring that the ship at last stood still of itself, and could by no exertion be made to proceed. That proud monarch, refusing to listen to such an explanation, ordered the original sentence to be immediately executed. Such appears to have been the only African voyage undertaken by the Persians, to whom the sea was an object of aversion, and even of superstitious dread.

Carthage, the greatest maritime and commercial state of antiquity, and which considered Africa and the Atlantic coast as her peculiar domain, must have made several exploratory voyages before she could establish those extensive connexions upon which her trade was founded. Of all such attempts, however, the record of one only remains. It consisted of an expedition on a very large scale, sent out, about 570 years before the Christian era, for the joint purposes of colonization and discovery, under an admiral named Hanno. He carried with him, in sixty large vessels, emigrants of both sexes to the number of thirty thousand. At the distance of two days' sail beyond the Pillars of Hercules, the Carthaginians founded the city of Thymioterium, and afterward, on the wooded promontory of Soloeis, erected a stately temple to Neptune. They then built 
successively four other cities; after which they came to the great river Lixus, flowing from Libya and the high boundary of the Atlas. Its banks were infested by numbers of wild beasts, and inhabited only by savage Ethiopians, living in caves, and repelling every friendly overture. Proceeding three days along a desert coast, the navigators reached an island, which they named Cerne, situated in a recess of the sea, where they established their last colony. Sailing onward still for a number of days, they saw a large river full of crocodiles and hippopotami, and containing various islands. The inhabitants were timid, and fled at their approach; but the coast presented some remarkable phenomena. During the day deep silence reigned; but as soon as the sun set, fires blazed on the shore, and the shouts of men were mingled with the varied sounds of cymbals, trumpets, and other musical instruments. This scene, being new to the Carthaginians, struck them with a sort of terror; but in fact it must have arisen from the custom prevalent over native Africa, where the inhabitants rest during the oppressive heat of the day, and spend great part of the night in dancing and festivity. On another shore the navigators were astonished to see the land all on fire, and torrents of flame rushing into the sea,-an appearance doubtless owing to one of those conflagrations frequently occasioned in such countries by the practice of setting fire to the grass at the end of autumn. Next appeared an island in a bay, where they found a most singular race, bearing the human form, indeed, but covered with shaggy hair, resembling those satyrs and sylvan deities with which pagan mythology peopled the woods. These monsters, whom they call Gorillæ, and who seem evidently to have been orang-outangs, ran off on their approach, climbed rocks, and threw down stones on their pursuers; yet three females were caught, and their skins carried to Carthage. At length, the coast becoming desolate, and no longer affording either provisions or water, it was found necessary to return.

How far this voyage extended, and what proportion of the African coast it surveyed, has been the subject of long and learned controversy. The only two disputants who now appear on the field are Major Rennel and M. Gosselin; the former of whom believes that Hanno passed Sierra 
Leone, and that the bay and island of the Gorillae were Sherbro' Island and Sound; while the other terminates the voyage on the frontier of Morocco, at the entrance of the river Nun. The one supposes a run of about 600 miles, the other one of nearly 3000 ; and yet each theory is supported by profound and able arguments. In such a case who shall decide? I really have made some attempts to do so, without being able to come to so clear a decision as would justify me in interposing between two such mighty champions. But he who will undertake the study of the original works will be gratified by finding all the resources of learning, ingenuity, and acuteness exhausted by these two great writers on this curious subject.

The individual who in that early age made the most resolute and persevering efforts to explore Africa was Eudoxus, a native of the city of Cyzicus, who lived about 130 years before Christ. Alexandria was then the centre of naval enterprise, and her Greek princes the most zealous patrons of all useful undertakings. Eudoxus, happening to visit that city, was introduced to Ptolemy Euergetes, whom he ably assisted in prosecuting those schemes of discovery on which this monarch's mind appears to have been deeply intent. Where so much was unknown on every side, it was a subject of grave deliberation in what direction he should first proceed; and an expedition to trace the upper course and fountain of the Nile was at one time contemplated. But the spirit of adventure was soon turned towards another object by the arrival of a native of India, whom one of the king's vessels had saved from shipwreck, and who offered to act as pilot in leading Eudoxus to that opulent and celebrated region. The latter performed the voyage to India prosperously, and returned leden with wealth. Though not quite satisfied with the manner in which he was treated by the king, he yet undertook another expedition to the same quarter. On emerging from the Red Sea, he was driven by a storm upon the eastern coast of Africa, where he observed the land taking such a direction as inspired the idea that it might, by no vast circuit, lead round to the Straits of Gibraltar. To be the circumnavigator of Africa became from that moment the object to which the life of Eudoxus was devoted. On his return to Alexaneria, Euergetes was dead, and the succeeding sovereign gave him 
still greater cause of complaint; so that he determined to trust no more to the precarious patronage of princes, but to make a general appeal to the commercial public. The merchants of Cadiz were thought most likely to embrace his views; and on his way thither he passed through Rhodes, Marseilles, and other great maritime states, calling upon all who were animated with the generous spirit of enterprise vo accompany or to aid him in his undertaking. An extraordinary sensation seems to have been created in these commercial cities. Eudoxus easily assembled round him a considerable band of volunteers, and was enabled to equip amply, and even splendidly, two vessels furnished with medical men and artisans of various descriptions, and even enlivened by a band of youthful musicians. In this array he passed the Straits, and turned his prow as he imagined towards India. But his gay crew, inspired by himself probably with too flattering hopes, seem to have anticipated only a smooth and holyday excursion. When, therefore, they saw themselves ranging along an unknown and dreary shore, against which the waves of the mighty Atlantic were beating, they were seized with panic. In vain did Eudoxus urge the necessity of standing out to sea, as the only mode of successfully navigating his large and heavily-loaded ships; they obstinately insisted on his keeping close to land. The consequence was, as he had distinctly foretold, that the principal vessel was stranded upon one of those dangerous sand-banks which abound on the coast. The crew were so fortunate, however, as to convey ashore not only the cargo, but the timbers; out of which Eudoxus, with zeal that nothing could damp, contrived to put together another and smaller bark, in which he pursued the voyage. He came then to nations speaking a language which his fancy flattered him was the same that he had heard on the eastern coast of Africa. But at this moment, when he seemed on the eve of accomplishing his most sanguine hopes, the shattered state of his armament obliged him to return; retaining still the fullest confidence, that if the means could be found of equipping another, all his most brilliant hopes would be realized. Disgusted, however, with his band of timid volunteers, he overcame his reluctance to royal patronage. He sought the precarious aid of Bocchus, king of Mauritania, who received him well, and 
ordered an expedition to be prepared; but Eudoxus was privately warned that this treacherous prince, instead of forwarding him on his voyage, intended that his people should land and leave him to perish on an uninhabited island. It does not appear what motive the king could have for so base a design; however, the Greek, who had better means of judging than we have, believed it and fled. He made his next attempt in Spain, where he found no difficulty in equipping two other vessels, on board of which he placed seed-corn and materials for building, that in case of necessity he might land and raise a crop on a fertile little island which he had observed at an advanced point of his fermer voyage. Here, very unluckily, Posidonius, Strabo's informant, stops short, and refers to the Spaniards and Gaditanians for farther information; but profound silence reigns on their part, and the world probably must remain for ever in darkness as to the issue of this last expedition. It must not be concealed, that authors of great name, not excepting Strabo himself, have branded Eudoxus as a decided impostor; a reproach which many of the most eminent discoverers have been destined to bear. This geographer is a most merciless critic; but though his authorities are admitted to be good, his long objections, drawn from the internal evidence, do not appear at all conclusive. Antiquity has put sundry fables into the narrative of Eudoxus, by which his reputation has severely suffered. According to certain works, he pretended to have really made the circuit of Africa; to have visited some nations that were dumb; others without tongues; and one people who had no mouths, but received all their food by the nose. These are the wild exaggerations which, in a credulous age, a story undergoes in passing from one person to another. The descriptions of Strabo, collected from the best sources, with severe and even malignant scrutiny, contain none of those suspicious wonders, nor any event which at all exceeds the common course of nature.

A line of navigation along the eastern coast of Africa is described in a work of later date, written apparently after the establishment of the Roman power in Egypt. It is termed the Periplus of the Erythrean or Indian Sea, by an author whose name was Arrian; but it comprises not so much the result of any individual adventure as a general 
view of the commercial voyage regularly made thither from Alexandria. After passing Abyssinia, the navigators sailed along a coast (that of the modern Berbera) which abounded in a remarkable degree with myrrh, frankincense, and other odoriferous plants. They then reached Cape Aromata (Guardafui), which forms the termination of the Red Sea and the entrance into the Indian Ocean. The coast of Africa, in this latitude, afforded ivory in abundance, rhinoceros' horns, and tortoise-shell, the latter of which was extremely fine; and in return for these, arms, wine, and corn were the most acceptable commodities. The voyage terminated at a promontory and port called Rhapta, a fact which of itself would show the extent of ancient narigation in this direction, could the learned agree where that town was situated; but all the names being changed, and no observations of latitude having been made, it is impossible to fix with certainty any one position. Rhapta, according to Gosselin, was Magadoxo; according to Vossius and Vincent it was at or near Quiloa, a position more than double the distance of the first from Cape Guardafui. On this point Dr. Vincent seems clearly in the right. The names are all changed, but the natural features necessarily remain the same. Now the navigator is in one place represented as passing successively the seven mouths of a large river at short distances from each other; and these cannot possibly be found any where but in the series of estuaries on which Patta and Melinda are built, the principal. of which is that of the Quillimane,-a conclusion which necessarily carries the situation of Rhapta southward to Quiloa. Ptolemy, who wrote probably a century later, gives the more remote position of Prasum as a promontory, port, and city, to which in his time navigators were accustomed to sail. We have no fact to guide us to the locality of that town, except that it was two or three hundred miles south-east from Rhapta. Gosselin makes it Brava; but this is still short of the mouths of the seven rivers which afford the test of this chain of positions. Dr. Vincent, again, would have Prasum to be Mozambique; but though the coast runs south-east from Quiloa to Cape Delegado, from this last point to Mozambique the direction is south, and even a little south-west. At or near Cape Delegado, therefore, must, it appears, be fixed the boundary of ancient navigation along the castern co st of Africa. 


\section{CHAPTER III.}

\section{Settlements of the Arabs.}

ThE rise and triumph of the followers of Mohammed, who in fifty years spread their arms and their creed over half the eastern world, produced an immense change in the social system of Asia, and a still greater in that of Africa. Their ascendency at first was by no means inauspicious, and portended little of that deep darkness and barbarism in which it has since involved these two continents. After the first violences to which fanaticism had prompted the more ardent converts, the Saracen sway assumed a milder aspect, and their princes cultivated the arts, and even the sciences, with a zeal which had expired among the effeminate and corrupted descendants of the Greeks and Romans. Even the remote Mauritania, which seemed doomed to be the inheritance of a barbarous and nomadic race, was converted by them into a civilized empire ; and its capital, Fez, became a distinguished school of learning. Their love of improvement reached even the most distant regions. They introduced the camel, which, though a native of the sandy wastes of Arabia, was equally adapted to the still more immense and awful deserts that stretch so wide over Africa. Paths were opened through wilds which had hitherto defied all human efforts to penetrate. An intercourse by means of caravans was formed with the interior countries, to obtain a supply of gold and slaves; and, amid the sanguinary disputes which arose among the descendants of the prophet, many, whose ill fortune expossed them to the enmity of successful rivals, sought refuge on the opposite side of the Great Desert. By successive migrations, they not only became numerous in Central Africa, but, from superior skill in the art of war, rose to bethe ruling power. They founded several flourishing kingdoms in that part of the continent which Europeans vainly sought to reach, till they were recently explored by our enterprising countrymen. Of these states Ghana was the most flourishing, forming the great market for that gold in search of which merchants 
came from the remotest regions. Its sovereign was acknowledged as supreme by all the neighbouring princes; while his court displayed a splendour, and was adorned with objects, hitherto unexampled in Central Africa. Among its ornaments were painting, sculpture, and glass windows, which, being before unknown, excited the surprise and admiration of the natives. The king is said to have rode out attended by elephants and camelopards, tamed by an art then first introduced, and since lost. The natives were also dazzled by the display of a mass of solid gold, weighing thirty pounds, with which the throne was embellished. This prince is reported to have made a great profession of justice, going out twice every day, and presenting himself to all who wished to offer petition or complaint. The vicissitudes of fortune have subverted the kingdom of Ghana, and made its territory successively subject to Timbuctoo, Kashna, and Sackatoo; but our late travellers found it, under the changed name, or rather orthography, of Kano, still extensive and populous, and continuing to be the chief seat of the interior commerce of Africa.

Tocrur, about twenty-four days' journey north-west of Ghana, was a kingdom inferior indeed to the other, yet powerful and independent. It carried on an extensive traffic with the people of the "remotest west," who brought shells (cowries?) and brass, for which they received gold and ornaments. Mention is made of the fine cotton cloths which still form the staple manufacture. Tocrur appears evidently to be Sackatoo or Soccatoo, now the capital of an empire which comprehends Ghana and all the neighbouring countries. Indeed, in an oficial document communicated by Major Denham, we find this called the empire of Takror.

Kuku, to the eastward of Ghana, forms another kingdom, on whose power and extent the Arabian writers largely dilate. The sovereign is said to have a very numerous train of attendants, and the people to be uncommonly warlike, though rude in their manners and attire. The merchants, however, are represented as very richly dressed, and accustomed to visit and converse with the governors and nobility. This country is manifestly Bornou, named from its capital, which bears still the same appeliation. Twenty 
days' journey to the south was Kaugha, a city famous for industry and useful arts, and the women of which were skilled in the secrets of magic. Though the resemblance of name is rather imperfect, this seems to be Denham's Loggum, much celebrated by him for its ingenious labours and fine manufactures, as well as for the intelligence of its females; and, among a rude people, wit and witchery are always imagined to have a close connexion.

To the south of Ghana lay Wangara, a district that is said to have contained gold, the commodity for which African commerce was so much prized. This region is described as intersected and overflowed during the rainy season by the branches of the Nile (of the Negroes, or Niger), which impregnate the earth with the sand, it is said, whence this precious metal was extracted. As soon as the waters have retired, the inhabitants eagerly dig the ground, and every one finds more or less, "according to the gift of God." There seems to be some confusion of ideas about this country and its golden products. A district in the southern part of Soudan is called Oongoroo, or Ungura; but it no longer furnishes gold; nor is Ghana, at the present day, the market for that valuable staple of Central Africa. In the mountainous countries to the southwest this metal is still collected abundantly, in the very manner described by the Arabian writers.

The whole range of alpine territory to the southward of the regions now described was called Lamlam, and presented a continued scene of barbarous violence. It was branded as the land of the infidels, - of a people to whom none of the charities of life were due, and against whom the passions of cruelty and of avarice might be gratified without remorse. Expeditions or slave-hunts were therefore made into these unfortunate countries; when, after a bloody conflict, numerous victims were seized, carried off, and sold to the merchants of Northern Africa, who conveyed them to all parts of the eastern world. The same cruel and iniquitous traffic is carried on in a similar manner, and with unabated activity, at the present day.

Respecting Western Africa, the Arabians do not seem to have been very accurately informed. They describe the Atlantic as only about five hundred miles beyond Tocrur, although two thousand would have been nearer the truth; 
perhaps they mistook the great lake Dibbie for the sea. They mention the island of Ulil, whence were brought great quantities of salt, an article which is in constant demand throughout Soudan. Ulil, though called an island, was probably Walet, the great interior market for that mineral ; but all the features of the country around and beyond it seem to have been confusedly blended together by the Mohammedan authors.

At the time when the Arabian geographers flourished, the Christian religion was professed, not only in Abyssinia, but even in Nubia, to its northern frontier at Syene. The bigotry and dislike produced by hostile creeds, not only deprived these writers of the means of information, but led them to view with contempt every thing relating to countries accounted infidel. Their notices, therefore, of the regions in the Upper Nile, and along the western shores of the Red Sea, are exceedingly meager. It was otherwise, indeed, with the eastern coast of Africa on the Indian Ocean. The people of Southern Arabia, who were then actively employed in commerce and navigation, had not only explored, but formed establishments at Mombaza, Melinda, Mozambique, and at all the leading points on that coast; which were still found in their possession by the early Portuguese navigators.

For this general view of Central Africa in the twelfth century, we are indebted to Edrisi, Abulfeda, Ibn-al-Vardi, and other writers, who do not however pretend to have visited in person the regions which they describe. Arabic literature has, notwithstanding, been also enriched by the productions of some eminent travellers. Wahab and Abuzaid, in the ninth century, penetrated into China, and communicated to the western world the first distinct idea of that remarkable empire and people. Their career, however, was far surpassed in the fourteenth century by Ibn Batuta, a learned Mohammedan, who traversed the continents of Asia and Africa from the eastern ocean to the banks of the Niger. For a knowledge of his narrative the English public have just been indebted to the learned labours of Professor Lee of Cambridge, as a member of the Society for Oriental Translation. Unfortunately, he could only procure the work in a very abridged form, which renders it more an object of curiosity than as fitted to convey full information of the state of the world at that early per :od. 
It was from $\mathrm{Fez}$ that Ibn Batuta commenced his peregrination through Interior Africa. He went first to Segilmissa, which he describes as a handsome town, situated in a territory abounding with date-trees. Having joined a caravan, he came, after a journey of twenty-five days, to Thargari, which some manuscripts make Tagaza, and is therefore evidently the Tegazza of Leo, supposed by Major Rennel to be the modern Tishect, containing the mine whence Timbuctoo is chiefly supplied with salt. To our traveller the place appeared to contain no object desirable or agreeable: there was nothing but salt; the houses were built with slabs of that mineral, and roofed with the hides of camels. It even appeared to him that nature had lodged this commodity in regular tables in the mine, fitted for being conveyed to a distance; but he probably overlooked an artificial process by which it is usually brought into this form. From Thargari he went in twenty days to Tashila, three days beyond which commenced a desert of the most dreary aspect, where there was neither water, beast, nor bird, " nothing but sand and hills of sand." In ten days he came to Abu Latin, a large commercial town, crowded with merchants from various quarters of the continent. The manners of the people, as is indeed too common in the scenes of inland traffic throughout Africa, appeared to him very licentious, and wholly destitute of that decorum which usually marks a Mussulman residence. The women maintained a greater share of respectability than the other sex; yet this did not prevent them from hiring themselves as temporary wives to those whom the pursuits of trade induced to visit Abu Latin. The editor has not hazarded a conjecture what place this is ; but on finding it in one manuscript called Ayulatin, and in another Ewelatin, I think there is no doubt of its being Walet, which lay completely in the route of our traveller, and is the only great city in that quarter of Africa.

From Abu Latin the adventurer proceeded in twenty-four days to Mali, then the most flourishing country and city in that part of the continent. This Mali is evidently the Melli of Leo, who described it as situated on a river to the south of Timbuctoo ; but it is not so easy to identify it with any modern position. Our traveller makes heavy complaints of the cold reception and narrow bounty of an African potentate in this district. After waiting upon his majesty, he 
was informed that a present was on its way to him, and he feasted his imagination on the idea of some rich dress or grolden ornament; instead of which, the whole consisted of a crust of bread, a dried fish, and sour milk. He had the boldness to remonstrate with the king on this donation, declaring, that in course of travelling over the whole world, he had never received the like; and his majesty, instead of being incensed, began to extend to him some measure of bounty. Ibn Batuta, however, was disgusted by the abject homage paid to this monarch, as it still, is to the native princes of Africa; the courtiers, as they approached, casting dust on their heads, throwing themselves prostrate and grovelling on the earth, - a degradation which he had never witnessed in the most despotic courts of the East. Yet justice is admitted to have been most strictly administered, and property to be perfectly secure; as a proof of which, merchants from the most distant country, who died at Mali, were as assured of leaving their inheritance to their posterity as if it had been deposited at home. The traveller was astonished by the immense bulk of the trees of this region, in the hollow trunk of one of which he observed a weaver plying his trade.

Ibn Batuta on this part of his journey saw the Niger; and the view necessarily led to a conclusion opposite to that hitherto entertained by his countrymen, who considered it as flowing westward to the ocean. Destitute of all opportunity of complete observation, he fell into the opposite error, since prevalent in Northern Africa, and identified it with the Nile. He supposed it to flow by Timbuctoo, Kakaw (Kuku?), Yuwi (seemingly the Yeou, or river of Bornou), and then by Nubia to Egypt.

From Mali our traveller turned northward to Timbuctoo. This city was then subject to the former, governed by a negro viceroy, and far from possessing the celebrity and importance which it has since attained. The town is described as being chiefly peopled by merchants from Latham, but what particular country that was it appears now impossible to conjecture. He next proceeded eastward by $\mathrm{Ka}$ kaw, Bardama, and Nakda, where he seems to have been near Nubia, but gives no farther details till he again arrived at Fez.

About two centuries after Ibn Batuta, a very full de- 
scription of Africa was furnished by a geographer named Leo, who was even honoured with the surname of Africanus. He was a native of Granada, but after the capture of that city by Ferdinand, repaired to $\mathrm{Fez}$; and in that once eminent school, applied himself to acquire a knowledge of Arabic learning and of the African continent. He afterward travelled through a great part of the interior, and, having repaired to Rome, wrote his description of Africa under the auspices of Leo X. It appears, that since the time of Edrisi, one of those revolutions to which barbarous states are liable had greatly changed the aspect of these countries. Timbuctoo, which at the former period either did not exist, or was not thought worthy of mention, had now risen to be the most powerful of the interior kingdoms, and the great centre of commerce and wealth. Ghana, once possessed of imperial greatness, had already changed its name to Kano, and was ranked as tributary to Timbuctoo. Bornou appears under its old appellation; and several kingdoms which have since held a conspicuous place are mentioned for the first time,-Casena or Cassina (Kashna), Zegzeg, Zanfara, and Guber. Gago, represented as being four hundred miles south-east of Timbuctoo, is evidently Eyeo, lately visited by Clapperton. Ghinea, or Gheneoa, described as a city of great commerce and splendour, has been supposed to be Ghana; but I think it is evidently Jenne, which Park found to be the largest and most flourishing city of Bambarra. At Timbuctoo many of the merchants were extremely opulent, and two of them had obtained princesses in marriage. Literature was cultivated with ardour, and manuscripts bore a higher price than any other commodity. Izchia, the king, who had been successful in subduing all the neighbouring countries, maintained an army of 3000 horse, and a numerous infantry, partly armed with poisoned arrows. Gold, for which Timbuctoo had now become the chief mart, was lavishly employed in the ormament of his court and person. He displayed solid masses, larger even than the one at Ghana, and some of his ornaments weigehd 1300 ounces. The royal palace and several mosques were handsomely built of stone; but the ordinary habitations here, as in all Central Africa, were merely bell-shaped huts, the materials of which were stakes, clay, and reeds. 


\section{CHAPTER IV.}

\section{Portuguese Discoveries.}

Europe, for ten centuries, during the decline of the Roman empire, the irruption of the barbarous nations, and the operation of the rude systems of feudal polity, remained sunk in profound apathy respecting all objects relating to science, discovery, and distant commerce. The splendour of the Crescent for a short interval outshone all that was brightest in the Christian world; and the courts of Bagdad, of $\mathrm{Fez}$, and of Cordova were more refined and more enlightened than those of London and Paris. At a somewhat early period, it is true, the Hanse Towns and the Italian republics began to cultivate manufactures and commerce, and to lay the foundation of a still higher prosperity; but they carried on chiefly an inland or coasting trade. The naval efforts even of Venice and Genoa extended no farther than to bring from Alexandria and the shores of the Black Sea the commodities of India, which had been conveyed thither chiefly by caravans overland. Satisfied with the wealth and power to which they had been raised by this local and limited commerce, these celebrated republics $m$ ide no attempt to open a more extended path over the ocean. Their pilots, indeed, guided most of the vessels which were engaged in the early voyages of discovery; but they were employed, and the means furnished, by the great monarchs whose ports were situated upon the shores of the Atlantic:

About the end of the fifteenth century, the human mind began to make a grand movement in every direction; in religion, science, freedom, and industry. It eagerly sought, not only to break loose from that thraldom in which it had been bound for so many ages, but to rival and even surpass all that had been achieved during the most brilliant eras of antiquity. These high aims were peculiarly directed to the department of maritime discovery. The invention of the compass, the skill of the Venetian and Genoese pilots, and the knowledge transmitted from former times, inspired 
mankind with the hope of being able to pass all the ancient barriers, and to throw light upon regions hitherto unknown. A small power, long sunk in apathy and political degradation, started first in this career, and took the lead for a certain time of all the European states. Portugal, during the reign of its kings John and Emmanuel, stood pre-eminent in enterprise and intelligence. Prince Henry, in particular, a younger son of John I., devoted all his thoughts and his whole life to the promotion of naval undertakings. No idea, however, was yet entertained of the new worlds which were afterward discovered by the daring spirit of Columbus. The local position of Portugal, its wars and expeditions against Morocco, led to the idea that the western border of Africa was the best field for discovery. The information respecting this coast was still very limited; so that the passage of Cape Bojador by Gilianez, in 1433, caused a surprise and admiration almost equal to what were afterward excited by the discovery of America. A rapid progress was afterward made along the shore of the Sahara, and the Portuguese navigators were not long in reaching the fertile regions watered by the Senegal and the Gambia.

The early part of this progress was dreary in the extreme. The mariners saw only naked rocks and burning sands, stretching immeasurably into the interior, and affording no encouragement to any project of settlement. Beyond Cape Blanco, however, Nuno Tristan, in 1443, discovered the island of Arguin; and notwithstanding the disaster of Gonzalo da Cintra, who, in 1445, was killed by a party of Moors, the Portuguese made it for some time their principal establishment. The country was far from presenting a brilliant aspect, though it was visited by caravans of the "Brabariis and Luddaias" (the people of Bambarra and Ludamar), who gave a very favourable report of the interior regions. Besides the expected accession to the power and splendour of the monarchy, the Portuguese cherished another object still more fondly. They hoped to open an intercourse with a prince, or person, of whom they had heard much under the mysterious appellation of Prester John. This singular name seems to have been first introduced by travellers from Eastern Asia, where it had been applied to some Nestorian bishop, who held there a species of sovereignty; and as soon as ru- 
mours arrived of the Christian king of Abyssinia, he was concluded to be the real Prester John. His dominions being reported to stretch far inland, and as the breadth of the African continent was very imperfectly understood, the conclusion was formed, that a mission from the western coast might easily reach his capital. What were the precise expectations formed from an intercourse with this personage does not fully appear; but it seems to have been thoroughly rooted in the minds of the Portuguese, that they would be raised to a matchless height of glory and felicity, if they could by any means arrive at the court of Prester John. The principal instruction given to all officers employed in African service was, that, in every quarter and by every means, they should endeavour to effect this grand discovery. They accordingly never failed to put the question to all the wanderers of the desert, and to every caravan that came from the interior; but in vain-the name of Prester John had never been heard. The Portuguese then besought the natives, at all events, into whatever region their journeys might lead them, studiously to inquire if Prester John was there, or if any one knew where he was to be found; and, on the promise of a splendid reward in case of success, this was readily undertaken.

In 1446, Diniz Fernandez discovered Cape Verd, and in the following year Lancelot entered the Senegal. The Portuguese found in this neighbourhood fertile and populous regions, that promised to reward their exertions much more effectually than the visionary name after which they had so eagerly inquired. A circumstance occurred, also, most convenient for monarchs who contemplate an extension of dominion. Bemoy, a prince of the Jaloff nation, came to Arguin, complaining that he had been driven from the throne, and entreating the aid of the Portuguese to restore to him his crown, which he was willing to wear as their ally, and even as their vassal. Bemoy was received with open arms, and conveyed to Jisbon. Here he experienced a brilliant reception, and his visit was celebrated by all the festal exhibitions peculiar to that age,-bullfights, puppet-shows, and even feats of dogs. On this occasion Bemoy made a display of the agility of his native attendants, who, on foot, kept pace with the swiftest horses, E 
mounting and alighting from these animals at full gallop. After being instructed in the Christian religion, he was baptized, and did homage to the king and to the Pope for the crown which was to be placed on his head; for which purpose a powerful armament, under the command of Pero Vaz d'Acunha, was sent out with him to the banks of the Senegal.

The conclusion of this adventure was extremely tragical. A quarrel having arisen between. Bemoy and the commander, the latter stabbed the prince on board of his vessel. $\mathrm{W}^{\prime}$ hether this violent deed was prompted by the heat of passion, or by well-grounded suspicions of Bemoy's fidelity, was never fully investigated; but the king learned the event with deep regret, and even, in consequence, gave up his design of building a fort on the Senegal. He made, however, no pause in his indefatigable efforts to trace the abode of Prester John. Ambassadors were sent into the interior, and, according to De Barros, even as far as Timbuctoo. All endeavours were vain as to the primary object; but the Portuguese thereby gained a more complete knowledge of this part of Interior Africa than was afterward attained in Europe till a very recent period. Most of this intelligence, however, has either perished, or still remains locked up in the archives of the Lusitanian monarchy.

The Portuguese continued to prosecute African discovery, till, in 1471, they reached the Gold Coast, when, dazzled by the importance and splendour of the commodity, the commerce of which gave name to that region, they built Elmina (the mine), making it the capital of their possessions in this continent. Pushing onward to Benin, they received a curious account of an embassy said to be sent, at the accession of every new monarch, to the court of a sovereign called Ogane, resident seven or eight hundred miles in the interior. When the ambassadors were introduced, a silk curtain shrouded the monarch from their view, till the moment of their departure, when the royal foot was graciously put forth from under the veil, and "reverence done to it as to a holy thing." This statement greatly excited the curiosity of the Portuguese, to whom this mysterious monarch appeared, more likely than any they had yet heard of, to be Prester John. Who this Ogane really was has been a subject of much doubtful discussion. 
The Portugaese had for some time been desirous to frame a title to this extensive coast, part of which they had now discovered. They appealed chiefly to the religion, or rather to the superstition, of the age. The maxim had been early established, that whatever country should be conquered from infidel nations was to be held the property of the victors. This claim was rendered available by a grant obtained from the Pope, assigning to them in full dominion all lands which should be discovered beyond Cape Bojador, and in their. farther progress eastward. Hence, after the establishment at Elmina, the king no longer hesitated to assume the pompous title of Lord of Guinea, and instructed his commanders that, instead of the wooden cross hitherto erected in sign of conquest, they should raise pillars of stone double the height of a man, with suitable inscriptions, surmounted by crucifixes inlaid with lead. In 1484, Diego Cam sailed from Elmina in quest of new shores on which this emblem of Portuguese dominion might be planted. After passing Cape St. Catherine, he found himself involved in a very strong current setting out from the land, which was still distant ; though the water, when tasted, was found to be fresh. It was conjectured, therefore, that he was near the mouth of a great river, which proved to be the fact. It has since been celebrated under the name of the Zaire or Congo. Diego, on reaching its southern bank, erected his first pillar,-an event considered so memorable, that the stream itself has often, by Portuguese writers, been termed the "River of the Pillar." $\mathrm{He}$ ascended its borders, opened an intercourse with the natives, and inquired after the residence of their sovereign. They pointed to a place at a considerable distance in the interior, and undertook to guide thither a mission, which they pledged themselves, within a stipulated period, to lead back in safety. As the natives meantime passed and repassed on the most intimate footing, Diego took advantage of a moment when several of the principal persons were on board his ship, weighed anchor, and stood out to sea. He soothed the alarm visible in the countenances of their countrymen on shore, by signs, intimating that this step was taken solely to gratify the anxious desire of his sovereign to see and converse with these African chiefs; that in fifteen moons they should certainly 
be brought back again; and that, meanwhile, a number of his people should be left as hostages. Diego then sailed to Lisbon, where he introduced with triumph these living trophies of his discovery. The king was highly gratified, and held many conversations with the Congo princes, whom he loaded with honours, and caused to be conveyed back at the appointed period to the shores of the Zaire. On Diego's arrival at that river, it was highly gratifying to see, waiting on the bank, the part of his crew whom he had left as pledges, and respecting whom he had felt some anxiety. He was invited to court, where the king not only received him with kindness, but agreed to embrace Christianity, and to send several of his principal lords to Europe, to be instructed in its principles. They sailed, accordingly, and this new arrival of Congo leaders of the first rank gave fresh satisfaction at Lisbon. They remained two years, experiencing the very best treatment; and on their being considered ripe for baptism, the king stood godfather to the principal envoy, and his chief nobles to others; on which occasion the Africans received the names of the persons by whom they had been thus honoured.

In 1490, a new armament, guided by Ruy de Sousa, conveyed back the Congo nobles to their native country. The Portuguese, on their arrival, were received by the king in full pomp. The native troops approached in three lines, making so prodigious a noise with horns, kettledrums, and other instruments, and raising shouts so tremendous, as to surpass all that the Europeans had ever witnessed in Catholic processions and invocations to the saints. The king himself was seated in the midst of a large park, upon an ivory chair raised on a platform. He was dressed in rich and glossy skins of wild beasts, a bracelet of brass hanging from his left arm, a horse's tail from his shoulder, and on his head a bonnet of fine cloth woven from the palm-tree. He gave full permission to erect a church; and, when murmurs were heard from a few of his attendants, he instantly offered to put them to death on the spot; but the Portuguese laudably dissuaded him from so violent a step. He himself and all his nobles were baptized; and free scope was allowed to the exertions of the Catholic missionaries. These churchmen seem to have been really 
snimated with a very devoted and persevering zeal ; but they had, unfortunately, conceived an incorrect idea of what they came to teach, and, instead of inculcating the pure doctrines and precepts of Christianity, merely amused the people with empty and childish pageantry. The presentation of beads, Agni Dei, images of the Madonna and saints; the splendid processions; the rich furniture and solemn ceremonies of the church, dazzled the eyes of the savage natives, and made them view Christianity only as a gay and pompous pageant, in which it would be an amusement to join. The sacrament of baptism, to which the Catholics attach such pre-eminent importance, was chiefly recommended by a part of the ritual that consisted in putting into the mouth a certain quantity of salt, which, in Congo, is an extremely rare and valued commodity ; and the missionaries were not a little disconcerted to find that the very form by which the natives expressed baptism was "to eat salt." Thus an immense body of the people were very speedily baptized and called Christians, but without any idea of the duties and obligations which that sacred name imposes.. There was, however, one point which the missionaries soon began very conscientiously, and perhaps in rather too hasty and peremptory a manner, to enforce. Appalled by the host of wives that surrounded every African prince or chief, who fulfilled for him every purpose of state and domestic service, and whom it had been his constant study and pride to multiply, the missionaries made a call on their converts to select one, and to make a sweeping dismissal of all the others. This was considered an unwarrantable inroad on one of the most venerated institutions of the realm of Congo. To the aged monarch the privation appeared so intolerable- that he thereupon renounced his Christian profession, and plunged again into the abyss of pagan superstition. Happily, Alphonso, the youthful heirapparent, saw nothing so dreadful in the sacrifice; he cheerfully submitted to it, and, braving his father's displeasure, remained attached to the Portuguese. The old king dying soon after, the zealous convert became entitled to reign; but his brother, Panso Aquitimo, supported by the nobles and almost the whole nation, raised the standard of rebellion in support of polygamy and paganism. A civil war ensued, in which the prince had little more than a - E 2 
handful of Portuguese to oppose to the innumerable host of his rebel countrymen; however, in consequence, as his adherents believed, of the appearance in the clouds, at one time of St. James, and at another of the Virgin Mary, he always came off victorious. Doubtless the better arms and discipline of the Portuguese rendered them superior in the field to the tumultuary host of their rude assailants.

Alphonso being thus firmly seated on his throne, the missionaries for a time secured a safe and comfortable establishment in Congo. Being reinforced by successive bo. dies of their brethren, they spread over the neighbouring countries, Sundi, Pango, Concobella, Maopongo, many tracts of which were rich and populous, though the state of society was often extremely rude. Every where their career was nearly similar. The people gave them the most cordial reception, flocked in crowds to witness and to share in the pomp of their ceremonies, accepted with thankfulness their sacred gifts, and received by thousands the rite of baptism. They were not, however, on this account prepared to renounce their ancient habits and superstitions. The inquisition, which was speedily instituted among their ecclesiastical arrangements, caused a sudden revulsion; and the missionaries thenceforth maintained only a precarious and even a perilous position. They were much reproached, it appears, for the rough and violent methods employed to effect their pious purposes; and though they treat the accusation as most unjust, some of the proceedings of which they boast with the greatest satisfaction tend not a little to countenance the charge. When, for example, they could not persuade the people to renounce their idols, they used a large staff with which they threw them down and beat them in pieces; they even sometimes stole secretly into the temples and set them on fire. A missionary at Maopongo having met one of the queens, and finding her mind inaccessible to all his instructions, determined to use sharper remedies, and, seizing a whip, began to apply it to her majesty's person. The effect he describes as most auspicious; every successive blow opened her eyes more and more to the truth, and she at length declared herself wholly unable to resist such affecting arguments in favour of the Catholic doctrine. It was found, however, that she had hastened to the king with loud complaints respecting this 
mode of spiritual illumination, and the missionaries thenceforth lost all favour both with that prince and the ladies of his court, being allowed to remain solely through dread of the Portuguese. In only one other instance were they permitted to employ this mode of conversion. The smith, in consequence of the skill, strange in the eyes of a rude people, with which he manufactured various arms and implements, was viewed by them as possessing a measure of superhuman power; and he had thus been encouraged to advance pretensions to the character of a divinity, which were very generally admitted. The missionaries appealed to the king respecting this impious assumption; and that prince, conceiving it to interfere with the respect due to himself, agreed to deliver into their hands the unfortunate smith, to be converted into a mortal in any manner they might judge efficacious. After a short and unsuccessful argument, they had recourse to the above potent instrument of conversion; yet Vulcan, deserted in this extremity by all his votaries, made still a firm stand for his celestial dignity, till the blood began to stream from his back and shoulders, when he finally yielded, and renounced all pretensions to a divine origin.

Farther acquaintance discovered other irregularities, against which a painful struggle was to be maintained. It was a prevailing practice, that before marriage the two parties should live together for some time, and make trial of each other's tempers and inclinations, before they formed the final engagement. To this system of probation the people were most obstinately attached, and the missionaries in vain denounced it, calling upon them at once either to marry or to separate. The young ladies were always the most anxious to have the full benefit of this experimental process; and the mothers, on being referred to, refused to incur responsibility, and expose themselves to the reproaches of their daughters, by urging them to an abridgment of the trial, of which they might afterward repent. The missionaries seem to have been most diligent in the task, as they call it, of "reducing strayed souls to matrimony." Father Benedict succeeded with no less than six hundred; but he found it such "laborious work," that he fell sick and died in consequence. Another subject of deep regret respected the many superstitious practices still prevalent, 
even among those who exhibited some sort of Christian profession. Sometimes the children brought for baptism proved to be bound with magic cords, to which the mothers, as an additional security from evil, had fastened beads, relics, and figures of the Agnus Dei. The chiefs, in like manner, while they gladly availed themselves of the protection promised from the wearing of crucifixes and images of the Virgin, were unprepared to part with the enchanted rings, and other pagan amulets, with which they had been accustomed to form a panoply around their persons. In case of dangerous illness, sorcery had been always contemplated as the main or sole remedy; and those who rejected its use were reproached as rather allowing their sick relations to die than incur the expense of a conjurer. But the most general and most pernicious application of magic was made in judicial proceedings. When a charge was advanced against any individual, no one ever thought of inquiring into the facts, or of collecting evidence; every case was decided by preternatural tests. The magicians prepared a beverage, which produced on the guilty person, according to the measure of his iniquity, spasm, fainting, or death, but left the innocent quite free from harm. It seems a sound conclusion of the missionaries, that the draught was nodified according to the good or ill will of the magicians, or the liberality of the supposed culprit. This trial, called the bolungo, was indeed renounced by the king, but only to substitute another, in which the accused was made to bend over a large basin of water, when, if he fell in, he was concluded guilty. At other times, a bar of red-hot iron was passed along the leg, or the arm was thrust into scalding water; and if the natural effects followed, the person's head was immediately struck off. Snail-shells, applied to the temples, if they stuck, inferred guilt. When a dispute arose between man and man, the plan was to place a shell on the head of each, and make them stoop; when he from off whose head the shell first dropped had a verdict found against him. While we wonder at the deplorable ignorence on which these practices were founded, we must not forget that the "judgments of God," as they were termed, employed by our sage ancestors during the middle ages, were founded on the same unenlightened views, and were in some cases absolutely identical. 
Other powers of still higher name held sway over the deluded minds of the people of Congo. Some ladies of rank went about beating a drum before them, with dishevelled hair, and pretending to work magical cures. There was also a race of mighty conjurers, called Scingilli, who had the power of giving and withdrawing rain at pleasure ; and they had a king called Ganja Chitorne, or God of the Earth, to whom its first-fruits were regularly offered. This person never died; but when tired of his sway on earth, he nominated his successor and killed himself,-a step doubtless prompted by the zeal of his followers; when they saw any danger of his reputation for immortality being compromised. This class argued strongly in favour of their vocation, as not only useful, but absolutely essential ; since without it the earth would be deprived of those influences by which alone it was enabled to minister to the wants of man. The people accordingly viewed with the deepest alarm any idea of giving offence to beings whose wrath might be displayed in devoting the land to utter sterility.

We do not possess any record of the period or the manner in which the Portuguese and their missionaries were expelled from Congo; but a late expedition did not find on the banks of the Zaire any trace or even recollection of either.

\section{CHAPTER V.}

\section{Early English Discoveries.}

The Portuguese, while they bore away the palm of maritime enterprise from all other nations, considered Africa most especially as a region which they had won for themselves, and had covered with trophies of discovery and victory. But after being subjected to the cruel and degrading yoke of Philip II. of Spain, they lost all their spirit and energy. Under the same influence, they became involved in hostility with the Dutch, who had risen to the first rank as a naval people, and whose squadrons successively stripped 
them of their most important possessions in this continent as well as in the East Indies. In 1637, Elmina itself, their capital, fell into the hands of these bold and successful rivals; and at present, the boasted lords and rulers of Guinea have not an acre left of their extensive dominions along the whole western coast; they retain only the Madeiras, Canaries, and other islands, which certainly are not destitute of beauty, and even of some degree of political and commercial value.

The Dutch did not remain long undisputed masters of the seas. The glorious and splendid results which had arisen from the discovery of the East and West Indies caused the ocean to be generally viewed as the grand theatre where wealth and glory were to be gained. The French and English nations, whose turn it was to take the lead in European affairs, pressed eagerly forward in this career, endeavouring at once to surpass their predecessors and each other. Many of their African settlements were formed with the view of securing a supply of slaves for their West India possessions. But a more distant, more innocent, and more brilliant object also attracted their attention. Flattering reports had reached Europe of the magnitude of the gold trade carried on at Timbuctoo and along the Niger. Letters were even received from Morocco, representing its treasures as surpassing those of Mexico and Peru. On that side, indeed, the immense Desert and its barbarous inhabitants rendered these central regions almost inaccessible; but there was another channel which appeared to open the fairest and most tempting prospects. According to all the geographical systems of that age, the great river Niger, which flowed through the interior of the continent, and by whose alluvion its plains were covered with gold, was understood to empty itself into the Atlantic either by the Senegal or Gambia, or, as was more commonly supposed, by both these rivers, imagined to be branches proceeding from the great stream. By ascending either the Senegal or Gambia, it therefore seemed possible to reach Timbuctoo and the country of Gold; and this became a favourite object with several European nations.

In 1618, a company was formed in England for the purpose of exploring the Gambia. They sent out, that same year, Richard Thompson, a person of spirit and enterprise, 
in charge of the Catherine of 120 tons, with a cargo worth nearly two thousand pounds sterling. In the month of December he entered the river; and proceeding as high as Kassan, a fortified town, where he left most of his crew, he pushed on in boats. The Portuguese, who were still numerous in that district, and retained all their lofty claims, were seized with bitter jealousy at this expedition made by a foreign and rival power. Led on by Hector Nunez, they furiously attacked the party which had been left at Kassan, and succeeded in making a general massacre of the English. Thompson, on learning these dreadful tidings, although unable to make any effort to avenge the slaughter of his countrymen, still maintained his station on the river, and sent home encouraging accounts of the general prospects of the undertaking. The company listened to his statement, and sent out another vessel, which unfortunately arrived at an improper season, and lost most of the crew by sickness. Even yet they were not dismayed, but, retaining their ardour unabated, fitted out a third and larger expedition, consisting of the Sion of 200 tons, and the St. John of 50 , and gave the command to Richard Jobson, to whom we are indebted for the first satisfactory account of the great river-districts of Western Africa.

Jobson entered the Gambia in November, 1620; but what was his dismay on receiving the tidings that Thompson had perished by the hands of his own men! Mutiny was then a frequent occurrence on these hard and distant services; but how it arose in this case, or who was to blame, was never duly investigated. The crew are said to have been unanimous in representing the conduct of their leader as oppressive and intolerable; but, in regard to a man of unitoubted spirit and enterprise, and who fell the first of so many victims in the cause of African discovery, we should not receive too readily the report of those who had so deep an interest in painting his character in the darkest colours.

Jobson, notwithstanding the shock caused by this intelligence, did not suffer himself to be discouraged, but pushing briskly up the river, soon arrived at Kassan. The Portuguese inhabitants in general had fled before his arrival, while the few who remained professed, in respect to Hector Nunez and the massacre of the English crew, an ignorance, 
and even a horror, for which he gave them very little credit. He had reason, on the contrary, to believe that they were forming a scheme of attack, and even urging the natives to rise against the English; and such was the dread of their machinations that scarcely any one could be prevailed on to act as his pilot. Notwithstanding these suspicions and alarms, he still pursued his course ; but after passing the falls of Barraconda he found himself involved in great difficulties. The ascent was to be made against a rapid current : the frequency of hidden rocks made it dangerous to sail in the night; and the boat often struck upon sand-banks and shallows, when it was necessary for the crew to strip and go into the water, in order to push it over these obstacles. They were once obliged to carry it a mile and a half, till they found a deeper channel.

The English now beheld an entirely new world, and a new aspect of nature. On every side there were immense forests of unknown trees, while both the land and the water were inhabited by multitudes of savage animals, whose roarings every night filled the air. Sometimes twenty crocodiles were seen together in the stream, and their voices, calling as it were to each other, resembled the "sound of a deep well," and might be heard at the distance of a league. Sea-horses also were observed tossing and snorting in every pool ; while elephants appeared in huge herds on the shore: at one place there were sixteen in a single troop. These last animals were an object of great terror to the natives, of whom only a few durst attack them with their long poisoned lances and assagays; but whenever the English made a movement against them, they fled like forest-deer, while, by their swiftness, they eluded all pursuit. Three balls were lodged in one individual, yet he made off, but was afterward found dead by the negroes. Lions, ounces, and leopards were also seen at a little distance; but, amid the alarms inspired by these formidable creatures, the sailors were anused by observing the various evolutions of the monkey tribe. The baboons marched along, sometimes in herds of several thousands, with several of the tallest in front, under the guidance of a principal leader, the lesser following behind, while a band of larger size brought up the rear. "Thus do they march on, and are very bold." At night, as they took their stand upon the hills, filling the air with con- 
fused cries, " one great voice would exalt itself, and the rest were all hushed." They mounted the trees to look at the English, the sight of whom seemed to inspire dissatisfaction; they grinned, shook the boughs violently, uttered angry cries, and when any overtures were made towards acquaintance, ran off at full speed. The erew skot one; but before they could reach the spot, the rest had carried it off. On tracing these creatures to their haunts in the depths of the forest, recesses were found, where the foliage had been so intertwined above, and the ground beaten so smooth beneath, as made it difficult to believe that these " bowers for dancing and disport" had not been framed by human hands.

Amid these difficulties and adventures, the party arrived at Tenda on the 26th January, 1621, where they expected to meet with Buckar Sano, the chief merchant or the Gambia. This personage accordingly waited on them; but being treated with brandy, used it so imrooderately that he lay all night dead drunk in the boat. Howerer, he seems on this occasion to bave been merely off his guard, as he acted ever after a very discreet and prudent part. He not only carried on traffic himself, but was employed as an agent in managing all the transactions of others. His good faith, however, seems to have been rendered somewhat doubtful by the accounts which he gave to Jobson of a city four months' journey in the interior, the roofs of which were covered with gold.

The report of a vessel come up to trade caused a great resort from the neighbouring districts; and the natives, rearing temporary hovels, soon fốrmed a little village on each side of the river. Speedily there appeared five hundred of a ruder race, covered with skins of wild animals, "the tails hanging as from the beasts." The women, who had never before seen a white man, ran away; but the sight of a few beads soon allured them to return. Unluckily, the universal cry was for salt, - a commodity deficient and much desired through all Central Africa; but Jobson, not duly apprized of this, had not laid in a sufficient stock. Every thing else was lightly prized in comparison; and many who were coming to swell the market, on learning this omission, instantly turned back. He obtained in exchange gold and ivory, and could have got hides in abundance, had they not been too bulky a commodity to bear the expense of convey ance. 
Buckar Sano undertook to introduce the English at the court of Tenda. On reaching the king's presence, they witnessed an example of the debasing homage vsually paid to negro princes, and of which Clapperton, in Eyeo, afterward saw several striking instances. The great and wealthy merchant, on appearing in the presence of the king, first fell on his knees, then throwing off his shirt, extended himself naked and flat on the ground, while his attendants almost buried him beneath dust and mud. After grovelling for some time in this prone position, he started up, shook off the earth, which two of his wives assisted in clearing from his person, and he was then speedily equipped in his best attire, with bow and quiver. He and his attendants, after having made a semblance of shooting at Jobson, laid their bows at his feet, which was understood as a token of homage; the king even assured the English captain that the country and every thing in it were thus placed at his disposal. In return for gifts so magnificent, it was impossible to refuse a few bottles of excellent brandy; the value of which, however, Jobson never expected to realize from these regal donations.

The English commander soon found himself in the middle of the dry season, and the river sinking lower and lower; yet he still made a hard struggle to ascend, animated by the deceitful or inflated reports of Buckar Sano concerning the eity of gold. At the distance of a few dars' joumer he heard of Tombaconda, which he conjectured to be Timbuctoo. The conclusion was most erroneous, that city being distant nearly a thousand miles; but Europeans had formed as yet no adequate idea of the dimensions of Africa. At length the stream became so shallow that Jobson found it in rain to attempt ascending higher. He began his rorage downward on the 10th Februars, proposing to make a fresh attempt during the season when the periodical rains should have filled the channel. This purpose was nerer executed. Both he and the company became involved in quarrels with the merchants, against whom he bitterly inveighs as persons who entirels disregarded every object beyond their own inmediate profit.

Jobson earlier, perhaps, than any other Englishman, had an opportunity of observing the manners and superstitions which are peculiar to native Africa. He found each prince 



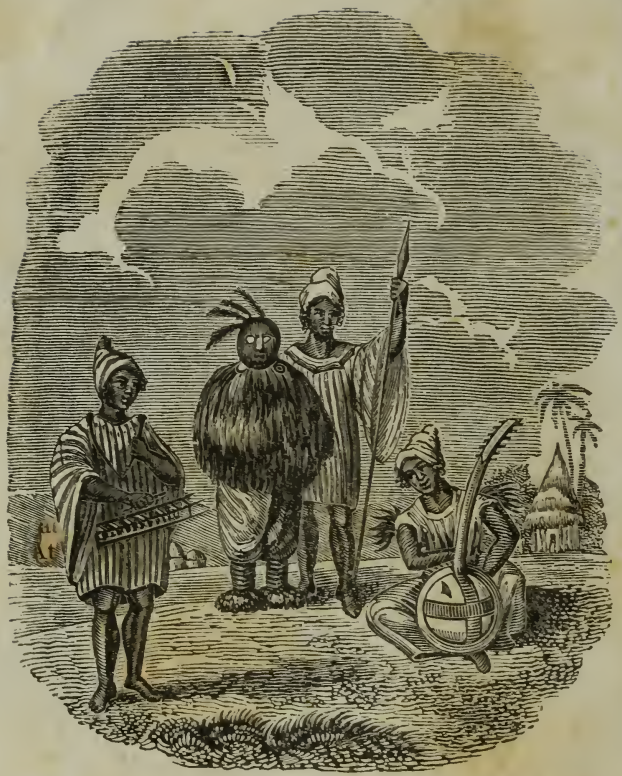

Group of Figures-Chief, Jillemen or Native Musicians, and Greegree Man or Magician.-[p. 63.] 
or chief attended by bands of musical bards, whom he dignifies with the title of "juddies or fiddlers," and compares them to the Irish rhymesters. 'These are called, as we learn from other authors, Jelle, or Jillemen, and perform on several instruments rudely formed of wood, making a very loud noise. These minstrels, with the Greegree men, or magicians, most fantastically attired, often form singular groups, as exhibited in the accompanying plate. The two chief festivals were those of circumcision and of funeral. The former, performed in a very rough manmer, attracted the whole country; the forest blazed with fires, while loud music, shouts, and dancing resounded throughout the night. At the funeral of chiefs there was much crying and lamentation, conducted in a somewhat mechanical manner, which reminded him of the Irish howl. Flowers of the sweetest scent were buried along with the deceased, and much gold was deposited for his service in the other world; but there is no mention of those human sacrifices which form so foul a blot on some of the most civilized African nations. At all festivals a conspicuous place was acted by a personage called Horey, which name our author interprets " the Devil." This being took his station in the adjoining woods, whence he sent forth tremendous sounds, supposed to be of sinister portent to all within hearing. The only remedy was to deposite, as near to the spot as any one would venture, a large supply of "belly-timber," the speedy disappearance of which authenticated to the villagers both the existence of this supernatural being and the fact of his having been appeased. To Jobson, on the contrary, this very circumstance, combined with the severe hoarseness with which sundry of the natives were afflicted, afforded a clew to the origin of this extraordinary roaring. Of this he had soon ocular demonstration. Happening, in company with a marabout, to hear the Horey in full cry from a neighbouring thicket, he seized a loaded musket, declaring aloud his resolution forthwith to discharge the contents at his infernal majesty. The marabout implored him to stop; the tremendous sound was changed into a low and fearful tone; and Jobson, on running to the spot, found this mighty demon in the shape of a huge negro, extended on the ground in such agonies of fear that he was unable even to ask for mercy.

The company, amid the divisions already alluded to, do 
not appear to have prosecuted farther their designs of discovery. The next attempt was made about 1660 or 1665 , by Vermuyden, a rich merchant on the Gambia, who fitted out * a boat well stored with beef, bacon, biscuit, rice, strong waters, and other comfortable supplies ; which, however, when he arrived at the flats and shallows, were found materially to impede the movement of the vessel. He came first to a wide expanse which he compares to Windermere lake, where the only difficulty was to find the main branch amid several that opened from different quarters. "Up the buffing stream," says he, "with sad laboux we wrought ;" and when they ascended higher, it became necessary often to drag the boat over the flats; for which purpose they were frequently obliged to strip naked and walk through the water. They were rather rudely received by the only tenants of these upper tracts, the crocodiles and river-horses, "ill pleased or unacquainted with any companions in these watery regions." One of the latter struck a hole in the boat with his teeth, an accident which proved very inconvenient, from the absence of any one skilled in carpentry; but by hanging a lantern at the stern, they induced these monsters, which are afraid of light shining in the dark, to maintain a respectful distance. On landing to search for gold, they were assailed by an incredible number of huge baboons, on which it is complained that no oratory except guns could produce any impression; and even after two or three of them had been killed, they attacked with increased and alarming fury, till successive discharges at length compelled them to retreat.

The sole object in this voyage was the discovery of gold. The adventurer landed at various points, washed the sand, and examined the rocks. He had carried out not only mercury, aqua regia, and large melting pots, but also a divining rod, which was not found to exhibit any virtue; however, on being laughed at by his companions for his delusive expectations from it, he persuaded himself that this potent instrument had. lost its qualities by being dried up during the voyage from England. On one occasion he found a large mass of apparent gold, which proved to be mere spar. The real metal, he observes, is never found in low, fertile, and woody spots, but always on naked and barren hills, imbedded in a reddish earth. At one place, by twenty days' labour, he succeeded in extracting twelve pounds. At length he 
declares, that he arrived " at the mouth of the mine itself, and saw gold in such abundance as surprised him with joy and admiration." However, he gives no notice of the posi"tion of this famous mine, the existence of which has not been confirmed by any subsequent observer.

It was not till 1720 that the spirit of African discovery again revived in England. The Duke of Chandos, then director of the African Company, concerned at the declining state of their affairs, entertained the idea of retrieving them by opening a path into the golden regions still reported to exist in the interior of Africa. At his suggestion, the company, in 1723, furnished Captain Bartholomew Stibbs with the usual means for sailing up the Gambia. On the 7th October this navigator arrived at James Island, the English settlement, about thirty miles from the mouth of the river, whence he immediately wrote to $\mathrm{Mr}$. Willy, the governor, who happened to be then visiting the factory of Joar, more than a hundred miles distant, asking him to engage canoes. $\mathrm{He}$ received for answer that there were none to be had, and was almost distracted to learn that Mr. Willy was giving himself no concern about the affair. Some days after, however, a boat brought down the dead body of the governor, who had fallen a victim to the fever of the climate, which had previously affected his brain. Thus, notwithstanding every exertion of Orfeur, who succeeded him, the equipment of the boats was delayed till the 11 th December, when the unfavourable season was fast approaching. Stibbs had assigned to him a crew of nineteen white men, of whom one indeed was as black as coal, but being a Christian, ranked as white, and served as interpreter; likewise twenty-nine grumettas, or hired negroes, with three female cooks ; and he afterward took on board a balafeu, or native musician, to enliven the spirits of the party.

Stibls set out on the 26 th of December, and the voyage proceeded for some time very agreeably. The English were every where well received, and at one place even a saphie, or charm, had been laid upon the bank for the purpose of drawing them on shore. The captain had endeavoured to conceal his object, but in vain; he found himself every where pointed out as the person who was come to bring down the gold. The native crew, however, predicted the most fearful disaster if he should attempt to proceed above 
the falls of Barraconda. As the boatts approached that fatal boundary, the Africans came in a body, and stated their firm determination on no account to proceed any farther. No one, they said, had ever gone beyond Barraconda,Barraconda was the end of the world,- - or if there existed any thing beyond, it was a frightful and barbarous region where life would be in continual danger. A long palaver and a bottle of Stibbs's very best brandy were necessary ere they would agree to accompany him beyond this dreaded boundary of the habitable universe.

The falls of Barraconda were not found so formidable as rumour had represented; they were narrows rather than falls, the channel being confined by rocky ledges and fragments, between which there was only one passage, where the canoes rubbed against the rock on each side. In this region of the Upper Gambia, the natives, belying all slanderous rumours, proved to be a harmless, good-humoured people, who, wherever the crew landed, met them with presents of fowls and provisions.

The severest exertion now became necessary in order to pass the flats and quicksands, which multiplied in proportion as they ascended, and over which the boats in some instances could only be dragged by main force. The wild and huge animals that occupy these regions appeared still more dangerous to the present adventurers than to their predecessors. The elephants, which had fled precipitately before Jobson, struck the greatest terror into this party; one of them on a certain occasion putting to flight the whole crew. They were even seen in bands crossing from one side of the water to the other. The river-horses also presented themselves every where in numerous herds; and though this animal generally moved in a sluggish and harmless manner, yet in the shallow places, when walking along the bottom of the river, he occasionally came into collision with the boat ; incensed at which, he was apt to strike a hole through it with his huge teeth, so as to endanger its sinking. ' If the courage of the crew against these mighty animals was not very conspicuous, their exertions in dragging the boat over the flats and shallows appear to have been most strenuous; yet so extremely unfavourable was the season, that at the end of two months Stibbs found himself, on the 22d February, when he had reached fifty-nine miles above Barraconda, 
obliged to stop short even of Tenda, and consequently of the point to which Jobson had formerly attained.

The commander, on his return, after making every allowance for the inauspicious season and circumstances, could not forbear expressing deep disappointment in regard to the expectations with which he had ascended the Gambia. He saw no appearance of that mighty channel which was to lead into the remote interior of Africa, and through so many great kingdoms. He declared his conviction that "its original or head is nothing near so far in the country as by the geographers has been represented." It did not of course appear to him to answer in any respect the descriptions given of the Niger,-it nowhere bore that name-it did not come out of any lake that he could hear of-it had no communication with the Senegal or any other great river. The natives reported that at twelve days' journey above Barraconda it dwindled into a rivulet, and " fowls walked over it." These statements were received most reluctantly and skeptically by Moore, now the company's factor on the Gambia, and a man of spirit and intelligence. He had even acquired some learning on the subject, and endeavoured to overwhelm Stibbs with quotations from Herodotus, Leo, Edrisi, and other high authorities. The mariner, though quite unable to cope with him in this field of discussion, did not the less steadily assert the plain facts which he had seen with his own eyes; and a degree of discouragement was felt, which prevented any other exploratory voyage from being undertaken for a considerable time into that part of the African continent.

\section{CHAPTER VI.}

\section{French Discoveries.}

France did not embark so early as some of the other powers in African discovery. Louis XIV., aided by his minister Colbert, was the first prince who studied to raise his kingdom to a high rank as a commercial and maritime 
power. But, unfortunately, according to the spirit of the time, the only mode in which he ever thought of promoting any branch of trade, was by vesting it in an exclusive company ; and when, according to the usual fate of such associations, one was involved in bankruptcy, another immediately supplied its place. Thus four successive companies rose and fell, till at length they all merged in that greatest and most fatal delusion, the Mississippi scheme. However, these copartneries, at their first formation, attracted many individuals of opulence and talent, and generally opened with a spirited career of enterprise and discovery. While the English sought to ascend the Gambia, the Senegal was the Niger to the French-the stream by which they hoped to penetrate upwards to Timbuctoo and the regions of gold. At the mouth of this river, about the year 1626, was founded the settlement of St. Louis, which has ever since continuea to be the capital of the French possessions in Africa.

The first person who brought home any accounts of French Africa was Jannequin, a young man of some rank, who, seeing, as he walked along the quay at Dieppe, a vessel bound for this unknown continent, took a sudden fancy to embark and make the voyage. The adventurers sailed on the 5th November, 1637, and touched at the Canaries; but the first spot on the continent where they landed was a part of the Sahara, near Cape Blanco. Jannequin was struck, in an extraordinary degree, with the desolate aspect of this region. It consisted wholly of a plain of soft sand, in which the feet were buried at every step; and a man, after walking fifty paces, was overwhelmed with fatigue. At Senegal the colony was found in so imperfect a state that the sailors were obliged to rear huts for their own accommodation; and, slight as these were, the labour under a burning sun was very severe. In ascending the river, however, he was delighted with the brilliant verdure of the banks, the majestic beauty of the trees, and the thick impenetrable underwood. Amid the deep solitude which distinguished the country, all the forests were filled with echoes. The natives received him hospitably, and he was much struck by their individual strength and courage, decidedly surpassing, as appeared to him, the similar qualities in Europeans. He saw a Moorish chief, called the Kamalingo, who, mounting on horseback, and brandishing three javelins and a cutlass, engaged a lion 
in single combat, and vanquished that mighty king of the desert. Flat noses and thick lips, so remote from his own ideas of the beautiful, were considered on the Senegal as forming the perfection of the human visage ; nay, he even fancies that they were produced by artificial processes. He was surprised by the enormous number of greegrees, or charms, in which the chiefs were enveloped. All the perils, of water, of wild beasts, and of battle, had an appropriate charm, by which the owner was secured against them. These potent greegrees were meroly slips of paper, which the marabouts, ur Mussulman doctors, had inscribed with Arabic characters ; and being then enclosed in cases of thick cloth, or even of gold and silver, were hung round the person in such profusion that they actually formed a species of armour. In some instances they composed such a load that the possessor was unable to mount on horseback without assistance.

The Sieur Brue, who, in 1697, was appointed directorgeneral of the company's affairs, was the person who did most for their prosperity, and made the greatest efforts to penetrate into the interior. In that year he embarked on a visit to the Siratik, or king of the Foulahs, whose territory lay about 400 miles up the Senegal. In ascending that river he was struck, like Jannequin, by the magnificent forests, and the profuse and luxuriant verdure with which they were clothed; while it was amusing to observe the numberless varieties of the monkey tribe, which were continually leaping from bough to bough. Elephants marched in bands of forty or fifty; and large herds of cattle fed on the rich meadows, though, during the season of inundation, they withdrew to the more elevated spots. At Kahayde, he was received by a chief belonging to the Siratik, accompanied by numerous attendants, among whom were his wife, daughters, and some female slaves, all mounted upon asses. He was cordially welcomed; yet the reflection suggested by his dealings with this gay and fair train was, that European beggars, however great their effrontery, might learn much from the example of the higher circles in Africa. When they can no longer ask, they begin to borrow, with the firm resolution of never repaying; and, what is worst of all, when they make a present, they hold it a deadly offence not to receive at least double the value in return. 
Brue sailed up the river, and landed at the port of Ghiorel ; then, with a party of armed attendants, set out for Gumel, about ten leagues in the interior, where the Siratik resided. At Ghiorel he was visited by Bukar Siré, one of the young princes, and afterward by the Kamalingo or general, and the Bouquenet, a venerable and aged negro, who filled an office similar to that of treasurer or prime minister. Thise two latter personages assured the director of the hearty welcome which awaited him at court ; intimating, at the same tine, their readiness to receive the presents which he was understood to have brought to the Siratik. These accorciingly were spread forth, and consisted of scarlet cloths, coloured - rorsteds, copper kettles, pieces of coral and amber, lrandy, spices, and a few coins, in portions respectively desined for the king, his wives, and the illustrious messengers; yet these liberal gifts, though they amply satisfied the great personages who received them, did not drain the finances of the company, since the entire cost did not exceed sixty or seventy pounds. The country was found level, well cultivated, and filled with such numerous herds that the French with difficulty made their way through them. At a village called Buksar, the Siré and his attendants again met them, brandishing their lances or assagayes, as if in the act to strike. This being explained as meant for the greatest possible compliment, Brue, in return, cocked his pistol at the young prince, with whom he then spent the evening. After being introduced to several ladies of the court, he was entertained with supper, consisting of fruits, kouskous, and uther simple products of African cookery. Then followed the folgar or dance, the favourite amusement of the negroes; but while all the youth of the village were tripting it gayly upon the green, amid songs and music, he foune more gratification in the kalder, or conversation carried on by the old men seated on mats in a circle. Their manners wer noble and dignified; they showed retentive memories ano quick apprehensions respecting the objects which came within their limited range of observation.

He set out next morning for the residence of the Siratik, being met and escorted thither by the Kamalingo. He found that prince surrounded by nune of those circinmstances which constitute in Europe the pomp of royalty. 
His palace was merely a cluster of mud cabins surrounded by a hedge of reeds. In one of these huts he reclined on a couch, while several of his wives and daughters sat round him on mats spread on the ground. The reception was perfectly friendly, and Brue even obtained permission to erect forts, - a privilege of which African princes are usual!y and indeed naturally jealous. The director was allowed full liberty to converse with the female circle, who werc by no means held in that state of austere seclusion which gives such a gloom to Mussulman society. The ladies began to talk in the most lively and familiar manner; and as Brue was thought to eye with admiration a handsome young princess of seventeen, she was tendered to him in marriage. He excused himself as one already joined in the bonds of matrimony; but the ladies professed themselves quite unable to conceive how this could form an objection, their young relative being of course prepared to share the honour with any reasonable number of rivals. It then behooved the director to explain the matrimonial system of Europe, which furnished, as it always does in Africa, ample ground for wonder and speculation. The lot of the French ladies was pronounced to be truly enviable; but Brue's own situation was much commiserated, especially in his present state of separation from his only wife.

The court being obliged to remove by the annoyance arising from a species of flying insect, Brue had an opportunity of observing the royal procession travelling in order. First came a numerous body of mounted musicians, who, performing on various instruments, produced a noise at once deafening and discordant. Next followed the royal ladies, mounted on the backs of camels in large osier baskets, which so completely enveloped their persons that their heads only wers seen peeping above. Their female domestics, riding by their side on asses, endeavoured to enliven them by incessant talk. The baggage behind was borne by a long train of camels and asses; while horsemen, in military array, with the king and his principal nobles at their head, closed the procession. The director and his party, while all this gay train passed by, exchanged with them mutual courtesies ard salutations. Having satisfactorily accomplished the immediate object of his journey, Brue returned to St. Louis. 
In 1698 , the same gentleman undertook another voyage, in which he aimed not merely at the limited objects above stated, but sought to ascend the Senegal as high as possible, and to open a commercial intercourse with the interior. In this voyage he had gained an amicable interview with the Siratik, and employed four of his negroes in destroying an enormous lion which had infested the neighbourhood. Farther on he observed some peculiar forms of the animal creation. The air for two hours was darkened by the passage of a cloud of locusts, and the boats were covered with their filth. Lions and elephants roamed in vast numbers; but the latter were quite tame and harmless unless when attacked. Monkeys swarmed in their usual multitudes; and in one place there was a species of a red colour, which appeared extremely surprised at the view of the strangers, and used to come in successive parties to gaze at them; on which occasion they conversed with each other, and even threw down dry branches upon the boats. The French, we know not why, fired and killed several; upon which they raised an extraordinary commotion, and sought, by throwing stones and sticks, to avenge the fall of their comrades; but, soon finding the contest unequal, they retired for safely into the woods. The navigatars were also introduced to a personage called "The King of the Bees," who, lyy the use of a particular charm, came to the boat surrounded by thousands of these insects, over which he exercised an absolute sway, guiding them as a shepherd does his sheep, and completely securing all his friends against their formidable stings.

On reaching Gallam, Brue found himself in a somewhat delicate position. Two rival princes disputed the throne, each holding, at his respective residence, a certain sway; but each also claiming for himself the entire homage, and all the presents brought by the director. The legitimate prince, in particular, sent his son to remonstrate that his undoubted claim ought not to be set aside for that of an ephemeral usurper. The European, however, acting steadily on the principle of self-interest, endeavoured to ascertain which of the two sovereigns could most benefit the company; and, finding the real power chiefly in the hands of the rebel, bestowed on him the larger portion of good things. The other party was thereby so incensed that he even threatened 
an attack; but the determined language of Brue, and the sight of the great guns which the French had on board, made him relinquish all hostile intentions.

The director now reached Dramanet, a thriving town, in: habited by several rich merchants, who traded as far as Timbuctoo, which, according to their computation, was five hundred leagues in the interior. This position was therefore thought the most convenient place for a fort, which was called St. Joseph, and continued long to be the principal seat of French commerce on the Upper Senegal. Brue then went up to Felu, where a large rock, crossing the river, forms a cataract, which it is almost impossible for vessels to pass. Quitting his boats, he proposed to ascend to the falls of Govinea, about forty leagues higher; but the water was getting so low, that, fearing the navigation downward should be interrupted, he returned to St. Louis.

Brue, in reply to numerous inquiries made by him on this journey, received accounts of the kingdom of Bambarra, of the Lake Maberia (Dibbie of Park), of Timbuctoo, of the caravans which came thither from Barbary, and even of masted vessels which were seen on the waters beyond. But the grand object of his research was the course of the $\mathrm{Ni}$ ger, concerning which he received two quite opposite answers. According to some it flowed westward from the Lake' Maberia, till it separated into the two channels of the Gambia and Senegal; but other and juster reports represented it as being distinct from both these rivers, and as passing eastward beyyond Timbuctoo. The testimonies transmitted to France in favour of this last opinion must have greatly preponderated, since both the great geographers, Delille and D'Anville, adopted this delineation; and yet the popular opinion in that country, as well as through Europe in general, long continued to regard the Niger and Senegal as one and the samie river.

Beyond Gallam lay another more tempting region, Bambouk, which contains mines of gold, the most productive of all that are to be found in the interior of Western Africa. The difficulty of penetrating thither, however, was extreme, the natives having completely barred the frontier against white men, in consequence of the tyranny exercised by the Portuguese, who had ruled and oppressed the district till they were cut off or expelled by a general insurrection. 
Many adventurers, after being induced by high bribes to undertake the journey, successively declined the enterprise. At length one Compagnon, laden with valuable presents, ventured to pass the boundary, and by his address succeeded in conciliating the inhabitants of the nearest village. A general alarm, however, spread through the country, when it was known that there was a white man within its preeincts; and representations were sent, that, according to the ancient salutary laws, he should forthwith be put to death;-yet Compagnon, by presents and address, succeeded in making his way from village to village. He contrived to visit the principal districts, and even to carry off a portion of the ghingan, or golden earth, which forms the pride and wealth of Bambouk. Brue then transmitted to France various projects, and among others that of conquering the country, which he undertook to effect with 1200 men; but such a degree of apathy prevailed at home, that none of these propositions made any impression. Subsequent governors, however, directed their attention to the same subject : two of them, Levens and David, even visited Bambouk in person; but no attempt was ultimately made either to conquer or to form settlements in that part of Africa: Indeed, though either step might have been successful in the first instance, the possession of such a territory would in the end have proved both costly and precarious.

From the accounts thus received, and which have been collected by Mr. Golberry, Bambouk appears to consist of a mass of lofty, naked, and barren mountains, and to contain scarcely any treasures, except those which are hid in the bowels of the earth. Besides, it is in the most arid and dreary spot of this gloomy region that the gold is found. Several hills in different quarters, not very high, but of considerable extent, have the same metallic substance distributed throughout, under the form of grains, spangles, and even of small lumps, which are always found larger in proportion to the depth of the bed. In the mine of Natakon the ore is mixed with earth, from which the precious dust is extracted by continued agitation in water; or it adheres to fragments of iron, emery, and lapis lazuli, whence it is easily detached. In the mine of Semayla, on the contrary, it is imbedded in a hard reddish loam, mixed with other subatances still harder, from which it can be extracted only by 
reducing them all to a powder. This is effected by pounding them with a pestle of hard wood, which is soon worn away by the resistance of the mineral substances. This mine, therefore, though richer than the other, is less valuable. The Farims, who are absolute chiefs of Bambouk, allow the mining operations only at certain seasons, when they themselves attend to levy a proportion of the proceeds. 'Two men, or two women,-for they are promiscuously employed in this occupation,--dig out the earth or other substances, which they hand to those who are to extract from it the gold. This metal they imagine to be a capricious being delighting to sport with their eager pursuit; and when they find a rich vein suddenly become unproductive, they call out "He is off." The pit whieh is six feet in diameter, is dug to the depth of thirty or forty, when the workers are usually arrested by an impenetrable bed of reddish-coloured marble, which, from certain indications, Golberry is led to consider as only the covering of much more abundant veins. These pits or shafts, by means of ladders, are carried down with perpendicular sides, which often fall in and bury the unfortunate workmen. This, however, does not at all discompose the survivors. They apprehend that the Devil, or rather a certain subterranean deity, having oceasion for labourers to conduct his own operations underneath, seizes in this manner the best miners he can find on the surface of the earth. Nor do they feel the least surprise, though they cannot conceal their regret, when, in the course of working, they light upon the skeletons of the victims. The Devil, they fancy, has then found himself mistaken in his choice, and has rudely thrown them back to the place whence he had withdrawn them.

The trade to Gallam appears, by the report of M. Saugnier, who undertook a voyage thither, to have been very profitable when carried on with suceess. Gold, ivory, and slaves could be purchased on easy terms ; and the natives, called Serawoolies, were intelligent and active, though inclined to be thievish. The voyage, however, is liable to many vicissitudes, the navigation often dangerous, and the natives on shore perpetually on the watch for plunder, especially the princes or robbers; which terms in Africa are nearly synonymous. The French government, also, had issued instructions not to proceed to great extremities 
against these high-born pilferers ; and hence Saugnier com? plains, that though he had at one time eight royal person; ages on board of his vessel as prisoners, he durst not turn them to any account. In this way the adventure was almost as likely to ruin as to enrich the person who undertook it.

The chief prosperity of the French settlements on the Senegal was derived from the gum-trade, of which Golberry has given a lively description. To the north of this river, where its fertile borders pass into the boundless deserts of the Sahara, grow large forests of that species of acacia from which the gum distils. It is crooked and stunted, resembling rather a bush or shrub than a tree. No incision is necessary; for under the influence of the hot winds the bark dries and cracks in various places. The liquor exudes, but by its tenacity remains attached in the form of drops, which are as clear and transparent as the finest rock-crystal. The Moorish tribes, to whom these woods belong, break up about the beginning of December from their desert encampments, and proceed to the gum district in a tumultuous crowd; the rich mounted on horses and camels, while the poor perform the journey on foot. Six weeks are spent in collecting the material; after which it is conveyed to the great annual fair held on the banks of the Senegal. The scene of this merchandise is an immense plain of white and moving sand, the desolate monotony of which is not broken by a single herb or a shrub. Here the French take their stand to await the arrival of the Moors. On the appointed morning they hear at a distance the confused noise of their armies in motion. Towards noon this vast and solitary plain appears covered with men, women, and animals innumerable, enveloped in clouds of dust. The chiefs ride beautiful horses; while the females of rank are seated on the backs of camels, elegantly caparisoned, in baskets covered with an awning. An incessant murmur pervades this barbarous assemblage, till, the whole having arrived, the camp is pitched, and a cannon fired as a signal for beginning the fair. The French relate, that every species of artifice and even threats are employed by these rude traffickers to enhance the price of their goods; yet they themselves, it would appear, have little right to complain. inasmuch as they confess that they have insen: 
sindy, and without attracting the notice of their barbarous customers, raised the kantar, by which the gum is measured, from five hundred to two thousand pounds weight.

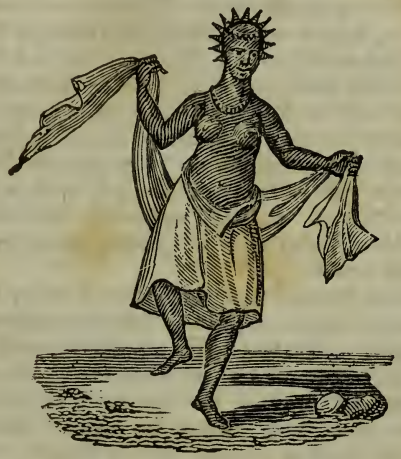

CHAPTER VII.

Early Proceedings of the African Association-Ledyard, Lucas, Houghton.

THE preceding narrative of French and English discoveries proves the imperfect success with which the earlier attempts to penetrate into the interior of Africa, though made by the most powerful nations of Europe, were attended. While the remotest extremities of land and sea in other quarters of the globe had been reached by British enterprise, this vast region remained an unseemly blank in the map of the earth. Such a circumstance was felt as discreditable to a great maritime and commercial nation, as well as to the sciences upon which the extension of geographical knowledge depends. To remove this reproach, a body of spirited individuals formed themselves into what G 2 
was termed the African Association. They subscribed the necessary funds, and sought out individuals duly qualified and possessed of sufficient courage to undertake such distant and adventurous missions. A committee, composed of Lord Rawdon, afterward Marquis of Hastings, Sir Joseph Banks, the Bishop of Landaff, Mr. Beaufoy, and Mr. Stuart, were nominated managers. It seemed scarcely probable that the mere offer to defray travelling expenses, which was all the society's finances could afford should induce persons with the requisite qualifications to engage in journeys so long and beset with so many perils; yet such is the native enterprise of Britons, that men eminently fitted for the task presented themselves, even in greater numbers than the society could receive.

The first adventurer was Mr. Ledyard, who, born a traveller, had spent his life in passing from one extremity of the earth to another. He had sailed round the world with Captain Cook, had lived for several years among the American Indians, and had made a journey with the most scanty means from Stockholm round the gulf of Bothnia, and thence to the remotest parts of Asiatic Russia. On his return he presented himself to Sir Joseph Banks, to whom he owed many obligations, just as that eminent person was looking out for an African discoverer. He immediately pronounced Ledyard to be the very man he wanted, and recommended him to Mr. Beaufoy, who was struck with his fine countenance, frank conversation, and an eye expressive of determined enterprise. Ledyard declared this scheme to be quite in unison with his own wishes ; and on being asked how soon he could set out, replied, "To-morrow." Affairs were not yet quite so matured; but he was soon after provided with a passage to Alexandria, with the view of first proceeding southward from Cairo to Sennaar, and thence traversing the entire breadth of the African continent. He arrived at Cairo on the 19th August, 1783, and while preparing for his journey into the interior, transmitted some bold, original, though somewhat fanciful observations upon Egypt, He represents the Delta as an unbounded plain of excellent land miserably cultivated; the villages as most wretched assemblages of poor mud-huts, full of dust, fleas, flies, and all the curses of Moses; and the people as below the rank of any savages he ever saw, wearing only a blue 
shirt and arrawers, and tattooed as much as the South Sea islanders. He bids his correspondents, if they wish to see Egyptian women, to look at any group of gipsies behind a hedge in Essex. The Mohammedans he describes as a trading, enterprising, superstitious, warlike set of vagabonds, who, wherever they are bent upon going, will and do go; but he complains that the condition of a Frank is rendered most humiliating and distressing by the furious bigotry of the Turks. It seemed inconceivable that such enmity should exist among men, and that beings of the same species should think and act in a manner so opposite. By conversing with the jelabs, or slave-merchants, he learned a good deal respecting the caravan-routes and countries of the interior. Every thing seemed ready for his departure, and he announced that his next communication would be from Sennaar; but, on the contrary, the first tidings received were those of his death. Some delays in the departure of the caravan, working upon his impatient spirit, brought on a bilious complaint, to which he applied rash and violent remedies, and thus reduced himself to a state from which the care of Rossetti, the Venetian consul, and the skill of the best physicians of Cairo, sought in vain to deliver him.

The society had, at the time they engaged Ledyard, entered into terms with Mr. Lucas, a gentleman who, being captured in his youth by a Sallee rover, had been three years a slave at the court of Morocco, and after his deliverance had been employed as vice-consul in that empire. Having spent sixteen years there, he had acquired an intimate knowledge of Africa and its languages. He was sent, by way of Tripoli, with instructions to accompany the caravan, which is understood to take the most direct route into the interior of the continent. Being provided with letters from the Tripolitan ambassador, he obtained the bey's permission, and even promises of assistance, for this expedition. At the same time he made an arrangement with two Shereefs, or descendants of the prophet, under which character their persons are sacred, to join a caravan of which they intended to make a part. He proceeded with them to Mesurata; but the Arabs in the neighbourhood, being in a state of rebellion, refused to furnish camels and guides, which, indeed, could scarcely be expected, as the bey had 
declined to grant them a safe-conduct through his territories. Mr. Lucas was therefore obliged to return to Tripoli, without being able to penetrate farther into the continent. He learned, however, from Imhammed, one of the Shereefs, who had been an extensive traveller, a variety of particulars respecting the interior regions. The society had at the same time made very particular inquiries of Ben Ali, a Morocco caravan trader, who happened to be in London. From these two sources Mr. Beaufoy was enabled to draw up a view of Central Africa; very imperfect indeed, yet superior to any that had ever before appeared.

According to the statements thus obtained, Bornou and Kashna were the most powerful states in that part of the continent, and formed even empires holding sway over a number of tributary kingdoms ; - a statement at that time correct, though affairs have since greatly changed. The Kashna caravan often crossed the Niger, and went onwards to great kingdoms beyond the Gold Coast, Gongah or Kong, Asiente or Ashantee, Yarba or Yarriba, through which last Clapperton recently travelled. Several extensive routes across the Desert were also delineated. In regard to the Niger, the report of Imhammed revived the error which represented that river as fiowing westward towards the Atlantic. The reason on which this opinion was founded will appear when we observe, that it was in Kashna that Ben Ali considered himself as having crossed that river. His Niger, then, was the Quarrama or river of Zirmie, which flows westward through Kashna and Sackatoo, and is only a tributary to the Quorra or great river, which we call the Niger. He describes the stream as very broad and rapid, probably from having seen it during the rainy season, when all the tropical rivers that are of any magnitude assume an imposing appearance.

Mr. Lucas made no farther effort to penetrate into Africa. The next expedition was made by a new agent, and from a different quarter. Major Houghton, who had resided for some time as consul at Morocco, and afterward in a military capacity at Goree, undertook the attempt to reach the Niger by the route of the Gambia, not, like Jobson and Stibbs, ascending its stream in boats, but travelling singly and by land. He seems to have been endowed with a gay, active, and sanguine spirit, fitted to carry him through the 
boldest undertakings, but without that cool and calculating temper which is necessary for him who endeavours to make his way amid scenes of peril and treachery. He began his journey early in 1791, and soon reached Medina, the capital of Woolli, where the venerable chief received him with extreme kindness, promised to furnish guides, and assured him that he might go to Timbuctoo with his staff in his hand. The only evil that befell him at Medina arose from a fire which broke out there, and spreading rapidly through buildings roofed with cane and matted grass, converted in an hour a town of a thousand houses into a heap of ashes. Major Houghton ran out with the rest of the people into the fields, saving only such few articles as could be carried with him. He writes, that by trading at Fattatenda a man may make 800 per cent., and may live in plenty on ten pounds a-year. Quitting the Gambia, he took the road through Bambouk, and arrived at Ferbanna on the Faleme. Here he was received with the most extraordinary kindness by the king, who gave him a guide and money to defray his expenses. A note was afterward received from him, dated Simbing, and which contained merely these words, - "Major Houghton's compliments to Dr. Laidley; is in good health on his way to Timbuctoo; robbed of all his goods by Fenda Bucar's son." This was the last communication from him; for soon afterward the negroes brought down to Pisania the melancholy tidings of his death, of which Mr. Park subsequently learned the particulars. Some Moors had persuaded the Major to accompany them to Tisheet, a place in the Great Desert, frequented on account of its salt-mines. In alluring him thither, their object, as appears from the result, was to rob him; for it was very much out of the direct route to Timbuctoo. Of this in a few days he became sensible, and insisted upon returning ; but they would not permit him to leave their party until after they had stripped him of every article in his possession. He wandered about for some time through the Desert without food or shelter, till, at length, quite exhausted, he sat down under a tree and expired. Mr. Park was shown the very spot where his re: mains were abandoned to the fowls of the air. 


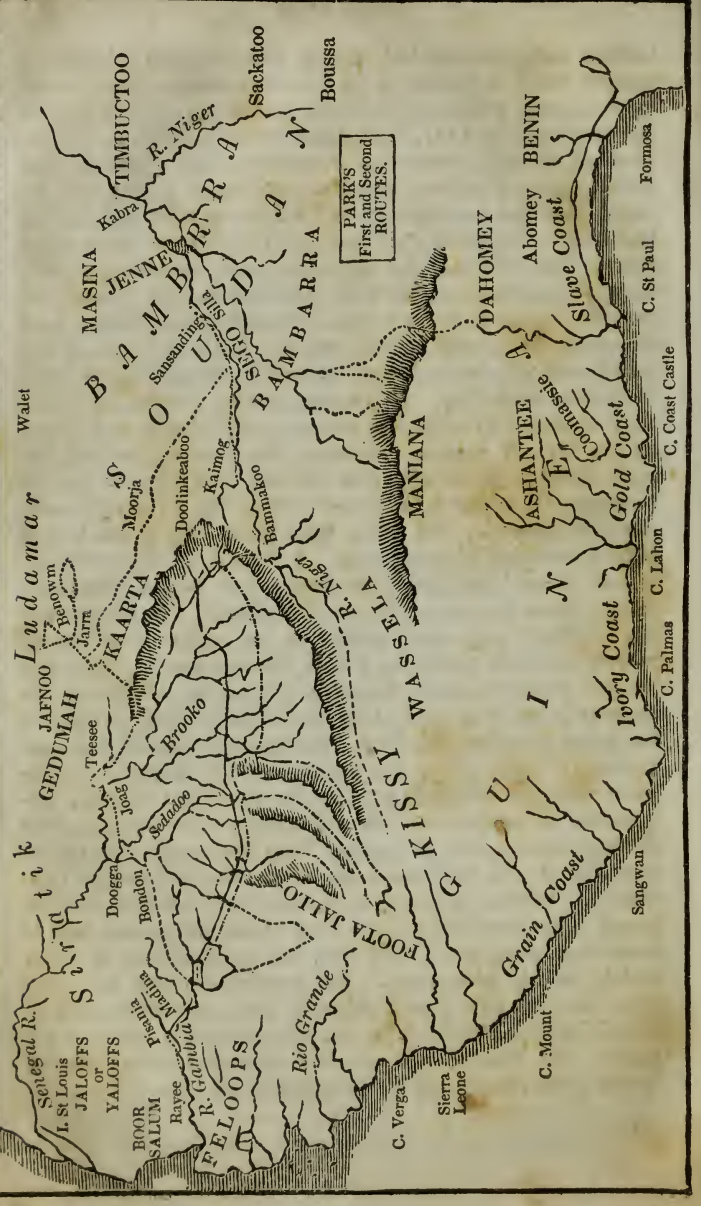




\section{CHAPTER VIII.}

\section{Park's First Journey.}

As soon as the Association were informed of the fate of Major Houghton, they accepted the offered services of Mr. Mungo Park, a native of Scotland, regularly bred to the medical profession, and just returned from a voyage to India. The committee were satisfied that Mr. Park possessed the requisite qualifications, though they could not yet be aware of the full extent of his courage and perseverance, nor of the unrivalled eminence to which, as a traveller, he was destined to rise under their auspices.

He set sail from Portsmouth on the 22d May, 1795, and on the 21st June arrived at Jillifree on the Gambia. He then proceeded to Pisania, in the fertile kingdom of Yani, where he was detained five months by illness under the hospitable roof of Dr. Laidley. While suffering from the fever of the climate, he acquired the Mandingo language, and obtained considerable information from the negro traders respecting the interior countries. The Gambia at this station was deep and muddy, overshadowed with impenetrable thickets of mangrove, and the stream filled with crocodiles and river-horses.

On the $2 \mathrm{~d}$ of December, Mr. Park took his departure, attended only by a few negro servants. On the 5th, he arrived at Medina, where the good old king received him with the same hospitality he had so liberally shown to Major Houghton; but earnestly exhorted him to take warning from the fate of that too adventurous traveller, and go no farther. Mr. Park was not to be thus discouraged; but immediately proceeded to enter the great forest or wilderness which separates this country from Bondou. He conformed to the example of his companions in hanging a charm or shred of cloth upon a tree at its entrance, which was completely covered with those guardian symbols. In two days he had passed the wood, and found Bondou a fine champaign country, watered by the Faleme. He had soon, however, to encounter the perils which cannot but await every: 
single and defenceless traveller who, loaded with valuable goods, passes through a succession of petty kingdoms wheré law is unknown. At Fatteconda, which he reached on the 21st December, he was obliged to wait upon Almami the king, who had already disgraced himself by the plunder of Major Houghton. Being desirous to preserve a good new blue coat, Mr. Park deemed it the wisest plan to wear it on his person, fondly hoping that it would not be actually stripped off his back. However, after the introductory ceremonial, the king began a warm panegyric on the wealth and generosity of the whites, whence he proceeded to the praises of the coat and its yellow buttons, concluding with expressing the delight with which he should wear it for the sake of his guest. He did not add, that if these hints were disregarded, it would be seized by force ; but our traveller, being thoroughly convinced that such was his intention, pulled off the coat, of which he humbly requested his majesty's acceptance. The king then abstained from farther spoil, and introduced him as a curiosity to his female circle. The ladies, after a careful survey, approved of his external appearance, with the exception of the two deformities of a white skin and a high nose; but for these they made ample allowance, being blemishes produced by the false taste of his mother, who had bathed him in milk when young, and, by pinching his nose, elevated it into its present absurd height. Park flat-. tered them on their jet-black skins and beautifully flattened noses; but was modestly warned that honey-mouth was not esteemed in Bondou.

Another forest intervened between that kingdom and $\mathrm{Ka}$ jaaga, which he crossed by moonlight, when the deep silence of the woods was interrupted only by the howling of wolves and byenas, which glided like shadows through the thickets. Scarcely was he arrived at Joag, in Kajatiga, when a party from Bacheri the king surrounded him, and declared his property forfeited, in consequence of having entered the country without payment of the duties. Thus he was stripped of all his goods except a small portion which he contrived to hide. Unable to procure a meal, he was sitting disconsolate under a bentang tree, when an aged female sluve came up and asked if he had dined. Being told that he had not, and had been robbed of every thing, she presented several handfuls of nuts, and went off before 
he could return thanks. Demba Sego, nephew to the king of Kasson, and who happened to be then at Joag endeavouring to negotiate a peace between his uncle and Bacheri, who were at variance, now undertook to guide him into that country, and did so; but exacted so many duties and presents, that Mr. Park was stripped of half his remaining stock. Kasson was found a level, fertile, and beautiful country. At Kooniakary, the capital, our traveller was well received by the king, and forwarded to Kemmoo, the principal town of Kaarta. Daisy, the sovereign of this last, likewise received him with the utmost kindness; but on learning his intention of taking the route to Timbuctoo through Bambarra, he stated this to be impossible, as he himself was then at war with the latter kingdom, and assured him that he would at once be killed if he attempted to enter it from Kaarta. There remained, therefore, no alternative but to go by way of the Moorish kingdom of Ludamar, a perilous and fatal route, in which Major Houghton had already perished. Mr. Park, however, hoped, by proceeding along the southern frontier, to reach Bambarra without coming much into contact with the barbarous and bigoted Moors by whom it was peopled.

On his arrival at Jarra, a large town chiefly inhabited by negroes, but entirely under the power of the Moors, he sent to Benowm, the capital, a messenger loaded with presents to negotiate with Ali, their chief, for a passage through his territories. After waiting a fortnight in great anxiety, he received a safe-conduct to Goombo, a place on the frontier of Bambarra. He first proceeded to Deena, a town in the possession of the Moors, who insulted and plundered him in the grossest manner, so that he was happy to escap by setting out at two in the morning of $3 \mathrm{~d}$ March. He passed next through Sampaka and Dalli, where he was received by the negro inhabitants with the usual kindness and hespitality of that race; he was even induced to stop a day at Dalli under promise of an escort; but this was a fatal pause. At Sami, on the 7th March, a party of Moorish horsemen appeared, for the purpose of telling him that $\mathrm{Fa}$ tima, the favourite wife of Ali, had been struck with curiosity to see what kind of creature a Christian was; that he must therefore come and show himself; but was assured 
that he would be well treated, and on satisfying her ma. jesty's wish, would even be forwarded on his journey.

Benowm, the Moorish capital, to which Park was then conveyed, proved to be a mere camp composed of a number of dirty tents, intermingled with herds of camels, horses, and oxen. He was surrounded by crowds actuated partly by curiosity and partly by that malignant feeling which always inflames the Moors against Christians. They snatched off his hat, made him unbutton his clothes to show the whiteness of his skin, and counted his fingers and toes to see if he were really of the same nature with themselves. After being kept for some time in the sun, he was lodged in a hut made of cornstalks, supported by posts, to one of which was tied a wild hog, evidently in derision, and to intimate that they were fit associates for each other. The hog, indeed, would have been the most harmless part of the affair, had not idle boys taken delight in tormenting and working up the animal to a constant state of fury. Crowds of men and women incessantly poured in to see the white man, and he was obliged to continue the whole day buttoning and unbuttoning his clothes, to show his skin, and the European manner of dressing and undressing. When euriosity was satisfied, the next amusement was to plague the Christian, and he became the sport of the meanest and most vulgar members of this rude community. The Moorish horsemen took him out and galloped round him, baiting him as if he had been a wild beast, twirling their swords in his: face to show their skill in horsemanship. Repeated attempts were made to compel him to work. One of Ali's sons desired him to mend the lock of a double-barrelled gun, and could scarcely be persuaded that all Europeans did not ply the trade of a smith. He was also installed as barber, and directed to shave the head of a young prince; but not relishing this function, he contrived to give his highness such a cut that Ali took the alarm and discharged him as incapable. That chief, under pretence of securing him against depredation, seized for himself all that remained of the traveller's property. Having examined the instruments, he was greatly astonished at the compass, and particularly at its always pointing towards the Great Desert. Park, thinking it vain to attempt any scientific expositions 
said that its direction was always to the place where his mother dwelt; whereupon Ali, struck with superstitious dread, desired it to be taken away.

Amid these insults, Park's sufferings were the more severe from the very scanty measure of food with which he was supplied. At midnight only he received a small mess of kouskous, not nearly enough to satisfy nature. He had been invited, indeed, to kill and dress his companion the hog ; but this he considered as a snare laid for him, believing that the Mohammedans, had they seen him feasting on this impure and hated flesh, would have killed him on the spot. As the dry season advanced, water became scarce and precious, and only a very limited quantity was allowed to reach the infidel, who thus endured the pangs of the most tormenting thirst. On one occasion, a Moor who was drawing water for his cows, yielded to his earnest entreaty that he might put the bucket to his mouth; then, struck with sudden alarm at such a profanation of the vessel, seized it, and poured the liquid into the trough, desiring him to share with the cattle. Park overcame the risings of pride, plunged his head into the water, and enjoyed a delicious draught.

During this dreadful period he contrived, nevertheless, to obtain some information. Even the rudest of his tormentors took pleasure in teaching him the Arabic characters, by tracing them upon the sand. Two Mohammedan travellers came to Benowm, from whom he obtained routes to Morocco, Walet, and Timbuctoo ; but they gave the most discouraging report as to the prospects of reaching the latter city. He was told it would not do; the Moors were there entirely masters, and viewed all Christians as children of the Devil and enemies of the prophet.

Fatima, the wife of Ali, whose curiosity to see a Christian he had been brought hither to gratify, was absent all this time and not like to arrive, while the rancour of the Moors, by whom Park was surrounded, became always more imbittered. A party even proposed that he should be condemned to death, though Ali's sons only recommended to put out his eyes, alleging that they resembled those of a cat. Hereupon he began seriously to consider the possibility of escape; but besides his being closely watched, the Desert was now so entirely destitute of water, that he must 
have perished on the road with thirst. He was therefore obliged to await the rainy season, however unfavourable for travelling through the negro territories.

Ali, on the 30th April, having occasion to move his quarters, came to Bubaker, the residence of Fatima, and Park was introduced to that favourite princess. The beauty of a Moorish female is measured entirely by her circumference; and to bestow this grace on their daughters, the mothers stuff them with enormous quantities of milk"and kouskous, the swallowing of which is enforced even with blows, till they attain that acme of beauty which renders them a load for a camel. The dimensions by which Fatima had captivated her royal lover were very enormous; she added to them Arab features and long black hair. This queen at first shrunk back with horror at seeing before her that monster, a Christian ; but after putting various questions, began to see in him nothing so wholly different from the rest of mankind. She presented to him a bowl of milk, and continued to show him the only kindness he met with during this dreadful captivity. A $A^{i}$ length her powerful intercession induced Ali to take Park with him to Jarra, where our traveller hoped to find the means of proceeding on his journey.

At Jarra a striking scene occurred. Ali, through avarice, had involved himself in the quarrel between the monarchs of Kaarta and Bambarra, and news arrived that Daisy was in full march to attack the town. The troops, who ought to have defended the place, fled at the first onset, and nothing remained for the inhabitants but to abandon it and escape from slaughter or slavery, the dreadful alternatives of African conquest. The scene was affecting. The local attachments of the African are strong; and the view of this disconsolate crowd quitting perhaps for ever their native spot, the scene of their early life, and where they had fixed all their hopes and desires, presented a striking picture of human calamity. Park would now very gladly have presented himself before his friend Daisy ; but being afraid that in the confusion he would be mistaken for a Moor, and killed as such, he thought it a safer course to join the retreat. He found more difficulty in escaping than he had expected, being seized by three Mohammedans, who threatened to carry him back to Ali, but finally contented themselves with robbing him of his cloak. In flying from 
savage man, he soon found himself involved in a danger still more alarming. He was in the midst of an immense desert, in which was neither food nor a drop of water. Having ascended the loftiest tree within his reach, he could see no boundary to the scene of desolation. The pangs of thirst became intolerable, a dimness spread over his eyes, and he felt as if this life, with all its mingled joys and miseries, was about to close, - as if all the hopes of glory by which he had been impelled to this adventurous career had vanished, and he was to perish at the moment when a few days more would have brought him to the Niger. Suddenly he saw a flash of lightning, and eagerly hailed it as a portent of rain; the wind then began to blow among the bushes, but it was a sand-wind which continued for an hour to fill the air. At last there burst forth a brighter flash, followed by a refreshing shower, which being received upon his clothes, and the moisture wrung ort, gave him new life. He travelled onwards, passing, but carefully shunning, a village of the Moors, when thirst, imperfectly satisfied, began again to torment him. Then he heard a heavenly sound-the croaking of frogs; and soon reached the muddy pools which they inhabited, when the thirst both of himself and his horse was thoroughly quenched. He came to a Foulah village, called Sherillah, where the dooty, or chief magistrate, shut the door in his face, and refused him a handful of corn; however, in passing the suburbs, a poor woman, who was spinning cotton in front of her hut, invited him to enter, and set before him a dish of kouskous. Next day he was hospitably received by a negro shepherd, who regaled him with dates and boiled corn; but happening to pronounce the word Nazarani (Christian), the wife and children screamed and ran out of the house, to which nothing could induce them to return.

At Wawra, Park considered himself beyond the reach of the Moors; and, being kindly received, determined to rest two or three days. When he was known to be on his way to Sego, the capital, several women came and besought him to ask the king about their sons, who had been taken away to the army. One had neither seen nor heard of hers for several years; she declared he was no heathen, but said his prayers daily, and that he was often the subject of her dreams. Leaving this place he came to Dingyee, where 
he seemed invested with a sacred character, - a man earnestly entreating a lock of his hair to be used as a saphie or charm ; and receiving permission to cut it off, he contrived to crop completely one side of the head. Proceeding towards Sego, he joined on the road several small negro parties ; but, as the country became more populous, hospitality was less common. In Moorja, however, though mostly peopled by Mohammedans, he found gayety and abundance. He next passed through several towns and villages, which, in the late war, had been systematically destroyed; the large bentang tree under which the inhabitants used to meet had been cut down, the wells were filled up, and every thing done which could render the neighbourhood uninhabitable. He passed also a coffle, or caravan, of about seventy slaves tied together by the neck with thongs of bullocks' hide, seven slaves upon each thong. His horse was now so completely worn out, that, instead of attempting to ride, he was content to drive it before him. Being also barefooted, and in the most miserable plight, he afforded a subject of merriment to the natives, who asked if he had been travelling to Mecca, and made ironical proposals for the purchase of his horse; even the slaves were ashamed to be seen in his company.

At length, the near approach to Sego was indicated by crowds hastening to its market; and Mr. Park was told that on the following day, the 21st July, that primary object of his search, the Joliba or Great Water, would appear before him. He passed a sleepless night, but, starting before day. break, he had the satisfaction, at eight o'clock, to see the smoke rising over Sego. He overtook some former fellow: travellers, and, in riding through a piece of marshy ground, one of them called out, geo affilli (see the water), and looking forwards, "I saw," says he, "with infinite pleasure, the great object of my mission, the long-sought-for majestio Niger, glittering to the morning sun, as broad as the Thames at Westminster, and flowing slowly to the castuard. I hastened to the brink, and having drunk of the water, lifted up my fervent thanks in prayer to the Great Ruler of all things, for having thus far crowned my endeavours with success."

Mr. Park now saw before him Sego, the capital of the kingdom of Bambarra. It consisted of four separate towno, 
two on each side of the river, surrounded with high mudwalls, - the houses, though only of clay, neatly whitewashed,-the streets commodious, with mosques rising in every quarter. The place was estimated to contain about thirty thousand inhabitants. The numerous canoes on the river, the crowded population, and the cultivated state of the surrounding country, presented altogether an appearance of civilization and magnificence little expected in the bosom of Africa. The traveller sought a passage to Segosee-Korro, the quarter where the king resided; but, owing to the crowd of passengers, he was detained two hours; during which time his majesty was apprized that a white man, poorly equipped, was about to pass the river to seek an audience. A chief was immediately sent, with an express order that the trave!ler should not cross without his majesty's permission, and pointed to a village at some distance, where it was recommended that the stranger should pass the night. Park, not a little disconcerted, repaired to the village; but as the order had not been accompanied with any provision for his reception, he found every door shut. Turning his horse loose to graze, he was preparing, as a security from wild beasts, to climb a tree and sleep among the branches, when a beautiful and affecting incident occurred, which gives a most pleasing view of the negro character. An old woman, returning from the labours of the field, cast on him a look of compassion, and desired him to follow her. She led him to an apartment in her hut, procured a fine fish, which she broiled for his supper, and spread a mat for him to sleep upon. She then desired her maidens, who had been gazing in fixed astonishment at the white man, to resume their tasks, which they continued to ply through a great part of the night. They cheered their labours with a song which must have been composed extcmpore, since Mr. Park, with deep emotion, discovered that he himself was the subject of it. It said, in a strain of affecting simplicity, - "The winds roared, and the rains fell. The poor white man, faint and weary, came and sat under our tree. He has no mother to bring him milk, no wife to grind his corn.-Chorus - Let us pity the white man, no mother has he," \&c. Our traveller was much affected, and next morning could not depart without requesting his landlady's acceptance of the only gift he had left, two out of the four brass buttons that still remained on his waistcoat. 
He remained two days in this village, during which he understood that he was the subject of much deliberation at court, the Moors and slave-merchants giving the most unfavourable reports of his character and purposes. A messenger came and asked if he had any present, and seemed much disappointed on being told that the Moors had robbed him of every thing. On the second day appeared another envoy, bearing an injunction from Mansong that the stranger should not enter Sego, but proceed forthwith on his journey; to defray the expenses of which, a bag, containing 5000 cowries, was delivered to him. Mr. Park estimates this sum at only twenty shillings; but according to the rate of provisions, it was worth much more, being sufficient to maintain, for fifty days, himself and his horse.

Two days brought our traveller to Sansanding, a large town with 10,000 inhabitants. He hoped to enter unnoticed, finding himself mistaken by the negroes for a Moor. Being taken, however, before Counti Mamadi, the dooty, or chief magistrate, he found a number of Mohammedans, who denied the supposed national connexion, and regarded him with their usual hatred and suspicion. Several even pretended they had seen him before, and one woman swore that she had kept his house three years at Gallam. The dooty put a negative on their proposition of dragging him by force to the mosque; but they climbed over in great numbers into the court where he had taken up his quarters for the night, insisting that he should perform his evening devotions, and eat eggs. The first proposal was positively declined; but the second he professed his utmost readiness to comply with. The eggs were accordingly brought, but raw, as the natives imagined it a part of European depravity to be fond of them in that state. His reluctance to eat raw eggs exalted him in the eyes of his sage visitants; his host accordingly killed a sheep, and gave him a plentiful supper.

His route now lay through woods, grievously infested with all kinds of wild animals. His guide suddenly wheeled his horse round, calling out " Wara billi billi! - a very large lion!" Mr. Park's steed was ill fitted to convey him from the scene of danger; but, seeing nothing, he supposed his guide mistaken, when the latter exclaimed, "God preserve me!" and the traveller then saw a very large red lion, with the head couched between the fore-paws. His eyes were fixed as by fascination on this sovereign of the beasts, and he 
expected every moment the fatal spring; but the savage animal, either not pressed by hunger or struck with some mysterious awe, remained immoveable, and allowed the party to pass unmolested. Real misery arose from a meaner cause, namely, the amazing swarms of mosquitoes which ascend from the swamps and creeks, and to whose attack, from the ragged state of his garments, he was exposed at every point. He was covered all over with blisters, and at night could get no rest. An affecting crisis next arrived. His horse, the faithful and suffering companion of his journey, had been daily becoming weaker. At lergth, stumbling over some rough ground, he fell : all his master's efforts were insufficient to raise him, and no alternative remained but to leave the poor animal; which, after collecting some grass and laying it before him, Mr. Prrk did, not without a sad presentiment that, ere long, he limself might in like manner lie down and perish with hunger and fatigue.

He now resolved to hire a boat, in which he was conveyed up the river to Silla, another large town, where his reception was so inhospitable that the dooty reluctantly permitted him to take shelter from the rain in a damp shed. Halfnaked, worn down by fatigue and sickness, and foreseeing the approach of the rains by which the whole country would be inundated, Mr. Park began seriously to contemplate his situation. All the obstacles now stated were small, when compared to the fact, that, in proceeding eastward, he would still be within the range of Moorish influence. He learned, that at Jenne, though included in Bambarra, the municipal power was chiefiy in the hands of these savage and merciless fanatics, who, at Timbuctoo also, held the entire sway. On these grounds he felt convinced that certain destruction awaited him in his progress eastward; that all his discoveries would perish with himself; and that his life would be sacrificed in vain. His only hope, and it was but faint, of ever reaching England, depended upon his return westward, and on his proceeding by the most direct route to the coast. On this course he determined, - a decision which was fully approved both by his employers and by the public.

During his stay at Silla, he used every effort to obtain information respecting the more eastern countries, particularly the kingdom of Timbuctoo, and the course of the 
Niger. He was told that the next great city along that river was Jenne, which was represented as very flourishing, and larger than Sego or any other place in Bambarra. Lower down, the river spread into an expanse, called Dibbie or the Dark Lake, so extensive that, in crossing it, the canoes for a whole day lost sight of land. On the eastern side the Niger issued out of this lake in two large branches, enclosing the alluvial country of Jinbala, when they again united in one channel, which flowed on to Kabra, the port of Timbuctoo. That town, situated a day's journey north from the Niger, was described to Mr. Park as the great centre of the commerce carried on between the Moors and negroes, by means of which the former people had filled it with Mohammedan converts; it was added, that the king and his principal offcers belonged to this faith, which was professed there with even more than the isual bigotry. An old negro related, that, on his entering a public inn, the landlord laid on the floor a mat and a rope, saying, "If you are a Mussulman, you are my friend, sil down on this mat; if not, you are my slave, and with this rope I will lead you to market." The king, named Abu Abrahima, was clothed in silk, lived in great pomp, and possessed immense riches. There has since appeared reason to suspect that, in these reports, both the bigotry and the splendour of Timbuctoo were somewhat exaggerated. Beyond this city, eastward, there was said to be a great kingdom called Houssa, with a capital of the same name, situated on the Niger. This also was somewhat inaccurate. There is no city called Houssa; and the term is applied, not to a kingdom, but to an extensive region comprehending many principalities, and through which the Niger does not pass.

Having formed his resolution, he forthwith began his return to the westward, and at Modiboo met with an unexpected and rather pleasing occurrence. While he was conversing with the dooty, a horse was heard to neigh; upon which the magistrate asked, smiling, if he knew who was speaking to him-and presently going out, led in the traveller's own horse, greatly recruited by rest. Mr. Park at first drove the animal before him, but afterward mounted, and found him of great benefit in passing the swamps and swollen rivulets which obstructed his route. He soon learned that dangers, even greater than he was aware of, had beset his 
path. The king of Bambarra had been at last so worked upon by Moorish counsellors, that, repenting even his former stinted kindness, he had sent messengers to apprehend Park, and to bring him a prisoner to Sego ; from which fate he escaped only by the retrograde direction he had taken. Thenceforth every door was resolutely shut against him; at Sansanding his best friend Counti Mamadi privately paid him a visit, and advised him to leave the city early next morning, and to make no delay in the vicinity of the capital. Accordingly, at a village near that city, he obtained a confirmation of the above tidings, and was exhorted to lose no time if he wished to get safe out of Bambarra. He then quitted the road, and struck off through fields and swamps. He once intended to swim across the Niger, and push towards the Gold Coast, but afterward resolved to pursue his course westward along the river, and thus ascertain its precise line. He had now nothing to subsist on except what charity bestowed, which was only an occasional handful of raw corn. There was also the greatest difficulty in finding a way through the swampy and inundated grounds. Once his horse and he sunk together to the neck in mud, and came out so completely besmeared, that they were compared by the natives to two dirty elephants. At another time, when he had stripped, and was leading his horse through a river that took him up to the neck, a friendly African called out, that he would perish if he went on, and undertook to procure a canoe; but when he came out, and his white skin was distinctly seen, the stranger put his hand to his mouth, exclaiming, in a low tone of amazement, "God preserve me! what is this?" He continued his kindness, however, and at Taffaro, where our traveller was shut out from every house, and obliged to sleep under a tree, brought him some supper. One of his most disagreeable encounters was at Souha, where the dooty, after a surly refusal of every refreshment, called upon a slave, whom he ordered to dig a pit, uttering, at the same time, expressions of anger and vexation. The hole became always deeper and deeper, till it assumed the appearance of a grave; and Park, who saw no one but himself likely to be put into it, began to think it was high time to be moving off. At length the slave went away, and returned, holding by the leg and arm the naked corpse of a boy about nine years old, 
which he threw in with an air of savage unconcern, the dooty exclaiming, "naphula attiniata! money lost, money lost !" Mr. Park withdrew in the deepest disgust at this display of brutal and selfish avarice. The only hearty meal he obtained for many days was from a Moslem convert, who, presenting a board, entreated him to write a saphie upon it, the return for which would be a good supper of rice and salt. This was too important an offer to be rejected from nice scruples. He therefore covered the board with the Lord's Prayer, which his host carefully washed off and drank, afterward licking the wood with his tongue. For this, in addition to his good rice supper, he received next morning a breakfast of meal and milk.

Our traveller now arrived at Bammakoo, where the level country on this side of the Niger terminates; but, on wishing to cross to the other bank, he was informed that the river would not be fordable for several months, and that no canoe could be procured large enough to transport himself and his horse. At length there was pointed out a path, rocky and difficult, but through which he might contrive to pick a way under the direction of a Jilli-kea, or singing man, who was going to Sibidooloo. The track, however, proved excessively rough and perilous; when his tuneful conductor, finding himself mistaken in the way, sprang up' among the cliffs, and quickly disappeared. Mir. Park was obliged to return and search among a number of glens, till he found a track marked by the tread of horses, which led him to Kooma, a beautiful sequestered village in the heart' of those barren mountains, where, on the produce of a smalk fertile valley, the inhabitants lived in peaceful abundance. They showed that kind hospitality which had been bestowed only scantily and occasionally in the still more fruitful regions below. Mr. Park set out next day for Sibidooloo; but on this route his last and greatest disaster awaited hin. In passing a rivulet he found a shepherd, who had been wounded by a party of banditti, and soon. after saw a man sitting on the stump of a tree, while from among the grass appeared the heads of six or seven others, with muskets in their hands. Seeing it impossible to escape, he resolved to put the best face he could on his situation. Pretending to take them for elephant-hunters, ho went up and asked if their chase had been successful. 
Instead of answering, one of them ordered him to dismount ; but then, as if recollecting himself, waved with his hand to proceed. The traveller had not gone far when he heard voices behind, and, looking round, saw them all in full pursuit, calling to him that they were sent to carry himself and his horse before the king of the Foulahs at Fooladoo. He did not attempt a vain resistance, but accompanied them till they came to a dark spot in the depth of the wood, when one of them said, "This place will do." The same man snatched off Mr. Park's hat; another instantly detached the last remaining button from his waistcoat; the rest searched his pockets, and investigated, with the most scrupulous accuracy, every portion of his apparel ; at last they determined to make sure work by stripping him to the. skin. As he pointed to his pocket-compass with earnest entreaty, one of them cocked a pistol, threatening, if he should touch it, to shoot him through the head. As they were carrying off every thing, they were seized with a feeling of remorse, and threw to him his worst shirt, a pair of trowsers, and his hat, in the crown of which he kept his memorandums.

After this blow Mr. Park felt a deeper depression than he had experienced under any former disaster. Naked and alone, in a vast wilderness, 500 miles from any settlement, surrounded by savage beasts and by men still more savage, he saw no prospect before him but to lie down and perish. From this depth of despondency his mind was suddenly revived by a mingled impression of nature and of religion. A small moss, in a state of fructification, struck his eye, the delicate conformation of whose roots, leaves, and capsule; could not be contemplated without admiration. He then bethought himself,--"Can that Being who planted, watered, and brought to perfection, in this obscure corner of the world, a thing which appears of so small importance; look with unconcern upon the situation and sufferings of creatures formed after his own image?" Inspired by these just and pious reflections, he started up and went on, despite of fatigue; and he soon found deliverance to be nearer than he had any reason to anticipate.

Having arrived at Sibidooloo, he waited on the mansa, or chief ruler of the town, and related his misfortune; when the latter, taking his pipe from his mouth, and tossing up 
his sleeve, said; with an indignant air, "Sit down, you shall have every thing restored to you; I have sworn it." He then ordered several of his people to go by darbreak next morning over the hills, and obtain the assistance of the dooty of Bammakoo in pursuing the robbers. Thus relieved, Mr. Park remained two days in this haspitable village, but found it pressed by so severe a famine that he could not think of tasking their kindness any longer, and went on to a town called Wonda. Here the mansa, who was at once chief magistrate and schoolmaster, receired him with kindness; but the famine was felt there with equal severity. Remarking five or six women who came daily to receive an allowance of corn from the doot $r$, he took leave to ask an explanation. "Look at that bor," said the magistrate; "his mother has sold him to me for tifty days' subsistence for herself and family." Our trareller, having during his stay become very unwell, heard the hospitable landlord and his wife lamenting to themselres the necessity of supporting him till he should either recover or die.

At the end of nine dass messengers arrived from Sibidooloo with Mr. Park's horse, harness, clothes, and even the pocket compass, though broken; all of which had been recovered by the exertions of the mansa. The horse, being reduced to a skeleton, and quite unfit for a journes over the flinty roads, was presented to his landlord; the saddle and bridle were sent to his generous friend at Sibiduoloo. Then, sick as he was, our traveller took leave, and went through several towns in the mountain territory of Manding, where he was, on the whole, hospitably treated. His arrival at Kanralia formed a most important era. There he met Karfa Taura, a negro, who was collecting a coffle of slaves for the Gambia. Karfa told him it was impossible at this season to traverse the Jallonka wilderness, in which there were eight rapid rivers to be crossed; but he offered to support him in the interval, and conduct him at the proper season to the Gambia, asking only a reasonable compensation, which was fixed at the value of a prime slave. Mr. Park was thus seasonably delivered from all his troubles, and obtained a more certain prospect of reaching home in safety.

He no longer encountered those difficuities and ricissi- 
tudes which had rendered the former part of his journey so full of interest and adventure. In traversing the high countries of Manding, Konkodoo, and Dindikoo, the chief object which attracted his attention was the mode of extracting gold. This precious metal did not occur in the form of ore, or in large masses, but its grains were mingled with a species of dust or sand. This golden earth appears to be chiefly washed down by torrents from the summit of the neighbouring chain of mountains; but it is collected with most advantage after the ground is dry and the harvest removed. Being indicated by its reddish tinge, it is put into large baskets, called calabashes, and agitated with a rotatory motion, so that at exery turn a portion of light sand mixed with water flies over the brim. The weightier parts then remaining are mixed with pure water, stirred, and carefully examined; and it is considered satisfactory if three or four grains are found in the whole basket. The dust is preserved in quills, which are often stuck in the hair as ornaments.

The most formidable part of the journey homeward was through the Jallonka wilderness, a vast and very dense forest, in which the caravan travelled during five days without seeing a human habitation. They marched in close and regular order, to protect the party against the attack of wild beasts, whose roarings were heard continually around them, and to which every one who straggled was sure to fall a victim. Such, too probably, was the lot of Nealee, a female slave, who, either from obstinacy or from excessive fatigue, refused to proceed any farther; and after vain attempts to compel her by the whip, she was abandoned to her fate. On emerging from this forest, they had no difficulty in passing through the fine open country of Dentila, and the smaller wilderness of Tenda. Mr. Park was again on the' Gambia; and on the 10th June, 1797, reached Pisania, where he was received as one risen from the dead; for all the traders from the interior had believed and reported, that, like Major Houghton, he was murdered by the Moors of $\mathrm{Lu}$ damar. Karfa, his benefactor, received double the stipulated price, and was overpowered with gratitude; but when he saw the commodious furniture, the skilful manufactures, the superiority in all the arts of life, displayed by the $\mathrm{Eu}$ ropeans, when compared with the attainments of his coun- 
trymen, he was deeply mortified, and exclaimed, "Black men are nothing !" expressing his surprise that Park could find any motive for coming to so miserable a land as Africa.

Mr. Park had some difficulty in reaching home. He was obliged to embark, on the 15 th June, in a vessel bound to America, and was afterward driven by stress of weather into the island of Antigua, whence he sailed on the 24th November, and on the 22d December arrived at Falmouth. He reached London before dawn on the morning of Christmas-day, and, in the garden of the British Museum, accidentally met his brother-in-law, Mr. Dickson. The interval of two years having elapsed since any tidings of him reached England, had caused him to be given up for lost, so that his friends and the public were equally astonished and delighted by his reappearance. The report of his unexpected return, after making such splendid discoveries, kindled throughout the nation a higher enthusiasm than had perhaps been excited by the result of any former mission of the same nature. To satisfy the public impatience, an outline was drawn up by Mr. Bryan Edwards, accompanied with learned and able geographical illustrations by Major Rernel. The entire narrative was published early in 1799 , and besides the interest inseparable from the remarkable events which it describes, the merit of being written in a pleasing and animated style has rendered it one of the most popular books in the English language.

\section{CHAPTER IX.}

\section{Park's Second Journey.}

The discoveries of Park, in his first journey, though the most splendid made by any modern traveller, rather excited than satisfied the national curiosity. The Niger had been seen flowing eastward into the interior of Africa; and hence a still deeper interest and mystery were suspended over the future course and termination of this great central stream. Kingdoms had been discovered, more flourishing and 
more populous than any formerly known in that continent; but other kingdoms, still greater and more wealthy, were reported to exist in regions which he had vainly attempted to reach. The lustre of his achievements had diffused among the public in general an ardour for discovery, which was formerly confined to a few enlightened individuals. It was evident, however, that the efforts of no private association could penetrate the depths of this vast continent, and overcome the obstacles presented by its distance, its deserts, and its barbarism. Thus it became necessary for George III., the patron and employer of Cook, to come forward as the promoter of discovery in this new sphere. In October, 1801 , accordingly, Mr. Park was invited by government to undertake an expedition on a larger scale into the interior of Africa. Having in the mean time married the daughter of Mr. Anderson, with whom he had served his apprenticeship as a surgeon, and having entered with some success on the practice of his profession in the neighbouring town of Peebles, it was supposed that, content with laurels so dearly earned, he had renounced a life of peril and adventure. But none of these ties could detain him, when the invitation was given to renew and complete his splendid career. His mind had been brooding on the subject with enthusiastic ardour. He had held much intercourse with Mr. Maxwell, a gentleman who had long commanded a vessel in the African trade, by whom he was persuaded that the Zaire, or Congo, which, since its discovery by the Portuguese, had been almost lost sight of by Europeans, would prove to be the channel by which the Niger, after watering all the regions of Interior Africa, enters the Atlantic. The scientific world were very much disposed to adopt Park's views on this subject ; and accordingly the whole plan of the expedition was adjusted with an avowed reference to them. The agitation of the public mind, by the change of ministry and the war with France, delayed farther proceedings till 1804, when he was desired by Lord Camden, the colonial secretary, to form his arrangements, with an assurance of being supplied with every means necessary for their accomplishment. The course which he now suggested was, that he should no longer travel as a single and unprotected wanderer; his experience decided him against such a mode of proceeding. He proposed to take with him a small party, 
who, being well armed and disciplined, might face almost any force which the natives could oppose to them; with these to proceed direct to Sego ; to build there two boats 40 feet long, and from thence to sail downwards to the estuary of the Congo. Instructions were sent out to Goree that he should be furnished liberally with men, and with every thing else of which he might stand in need.

Mr. Park sailed from Portsmouth in the Crescent transport on the 30th January, 1805. About the 8th March he arrived at the Cape Verd Islands ; and on the 28th reached Goree. There he provided himself with an officer and thirty-five soldiers, and with a large stock of asses from the islands, where the breed of these animals is excellent, and which appeared well fitted for traversing the rugged hills of the high country whence issue the sources of the Senegal and Niger. He took with him also two sailors and four artificers, who had been sent from England. But before all these measures could be completed a month had elapsed, and it was then evident that the rainy season could not be far distant, - a period in which travelling is very difficult, and extremely trying to European constitutions. It is clear, therefore, that it would have been prudent to remain at Goree or Pisania till that season had passed; but, in Mr. Park's elevated and enthusiastic state of mind, it would have been extremely painful to have lingered so long on the eve of his grand and favourite undertaking. He hoped, and it seemed possible, that before the middle of June, when the rains usually begin, he might reach the Niger, which could then be navigated without any very serious toil or exposure. He departed, therefore, with his little band from Pisania, on the 4th May, and proceeded through Medina, along the banks of the Gambia. With so strong a party, he was no longer dependent on the protection of the petty kings and mansas; but the Africans, seeing him so well provided, thought he had no longer any claim on their hospitality; on the contrary, they eagerly seized every opportunity to obtain some portion of the valuable articles which they saw in his possession. Thefts were common; the kings drove a hard bargain for presents : at one place the women, with immense labour, had emptied all the wells, that they might derive an advantage from selling the water. Submitting quietly to these little annoyances, Mr. Park proceeded 
along the Gambia, till he saw it flowing from the south between the hills of Foota Jalla and a high mountain called Muianta. Turning his face almost due west, he passed the streams of the Ba Lee, the Ba Fing, and the Ba Woollima, the three principal tributaries of the Senegal. This change of direction led him through a tract much more pleasing than that which he passed in his dreary return through Jallonka and its wilderness. The villages, built in delightful mountain-glens, and looking from their elevated precipices over a great extent of wooded plain, appeared romantic beyond any thing he had ever seen. The rocks near Sullo assumed every possible diversity of form, towering like ruined castles, spires, and pyramids. One mass of granite so strongly resembled the remains of a Gothic abbey, with its niches and ruined staircase, that it required some time to satisfy him that it was composed wholly of natural stone. The crossing of the rivers, now swelled to a considerable magnitude, was attended with many difficulties ; and in one of them Isaaco the guide was nearly devoured by a crocodile.

It was near Satadoo, soon after passing the Falene, that the party experienced the first tornado, which, marking the commencement of the rainy season, proved for them "the beginning of sorrows." In these tornadoes, violent storms of thunder and lightning are followed by deluges of rain, which cover the ground three feet deep, and have a peculiarly malignant influence on European constitutions. In three days twelve men were on the sick list. The natives, as they saw the strength of the expedition decline, became more bold and frequent in their predatory attacks. At Gimbia attempts were made to overpower, by main force, the whole party, and seize all they possessed; but the assault was repelled without bloodshed, by their merely presenting their muskets. At Maniakarro the whole population hung on their rear for a considerable time, headed by thirty of the king's sons ; and great delicacy was felt as to the mode of dealing with these august thieves, so long as their proceedings were not quite intolerable. One of them came up, and engaged Mr. Park in conversation, while another ran off with his fowling-piece ; and, on his attempting pursuit, the first took the opportunity of seizing his great coat. Orders were now given to fire on all depredators, royal or plebeian; 
and, after a few shots had been discharged without pro ducing any fatal effects, the thieves hid themselves among the rocks, and were merely seen peeping through the crevices.

The expedition continued to melt away beneath the deadly influence of an African climate. Every day added to the list of sick or dead, or of those who declared themselves unable to proceed. Near Bangassi, four men lay down at once ; it was even with difficulty that Mr. Park dragged forward his brother-in-law, Mr. Anderson, while he himself felt very sick and faint. His spirits were about to sink entirely, when, coming to an eminence, he obtained a distant view of the mountains, the southern base of which he knew to be watered by the Niger. Then indeed he forgot his fever, and thought only of climbing the blue hills which delighted his eyes.

But three weeks, during which he experienced the greatest difficulty and suffering, elapsed before he could arrive at that desired point. At length he reached the summit of the ridge which divides the Senegal from the Niger, and coming to the brow of the hill, saw again this majestic river rolling its immense stream along the plain. Yet his situation and prospects were gloomy indeed, when compared to those with which he had left the banks of the Gambia. Of thirty-eight men whom he then had with him, there survived only seven, all suffering from severe sickness, and some nearly at the last extremity. Still his mind was full of the most sanguine hope, especially when, on the 22d August, he felt himself floating on the waters of the Niger, and advancing towards the ultimate object of his ambition. He hired canoes to convey his party to Marraboo; and the river, here a mile in breadth, was so full and so deep, that its current carried him easily over the rapids, but with a rapidity which was even in a certain degree painful.

At Marraboo he sent forward the interpreter Isaaco to Mansong with part of the presents, and to treat with that monarch for protection, as well as for permission to build a boat. This envoy was absent several days, during which great anxiety was felt, heightened by several unfavourable rumours, among which was, that the king had killed him with his own hand and announced his purpose 
to do the same to every white man that should come within his reach. These fears were dispelled by the appearance of the royal singing man, who brought a message of welcome, with an invitation to repair to Sego, and deliver in person the remaining presents intended for the monarch. At Samee the party met Isaaco, who reported that there was something very odd in the reception which he had received from Mansong. That prince assured him, in general, that the expedition would be allowed to pass down the Niger; kut whenever the latter came to particulars, and proposed an interview with Mr. Park, the king began to draw squares and triangles with his finger on the sand; and in this geometrical operation his mind seemed wholly absorbed. Isaaco suspected that he laboured under some superstitious dread of white men, and sought by these figures to defend himself against their magic influence. It was finally arranged that the presents should be delivered, not to Mansong in person, but to Modibinne, his prime minister, who was to come to Samee for that purpose. He accordingly appeared, and began by requiring, in the king's name, an explanation why Park had come to Bambarra with so great a train from so distant a country, -allowing him a day to prepare his reply. Next morning the traveller gave an answer in form, representing his mission as chiefly commercial, and holding forth the advantages which Bambarra might reap by receiving European goods directly from the coast, instead of circuitously, as now, through Morocco, the Desert, Timbuctoo, and Jenne, having a profit levied upon them at every transfer. Modibinne expressed satisfaction both with the reasons and with the presents ; and on his return next day offered, on the part of Mansong, the option of building a boat either at Samee, Sego, Sansanding, or Jenne. Park chose Sansanding, thus enabling the king to avoid a personal interview with the Europeans, of which he seemed to entertain so mysterious a dread.

The voyage down the river was distressing; for, though the fatigue of travelling was avoided, the heat was so intense that it was thought sufficient to have roasted a sirloin: and the sick had thus no chance of recovery. Sansanding was found a prosperous and flourishing town, with a crowded market remarkably well-arranged. The leading articles, 
which were cloth of Houssa or Jenne, antimony, beads, and indigo, were each arranged in stalls, shaded by mats from the heat of the sun. There was a separate market for salt, the main staple of their trade. The whole presented a scene of commercial order and activity totally un: looked for in the interior of Africa.

Mansong had promised to furnish two boats; but they were late in arriving, and proved very defective. In order to raise money, it was necessary to sell a considerable quantity of goods. Nor was î without much trouble that the two skiffs were finally converted into the schooner $\mathrm{Jo}_{0}$ liba, forty feet long, six broad, and drawing only one foot of water, the fittest form for navigating the Niger downward to the ocean.

During Park's stay at Sansanding he had the misfortune to lose his brother-in-law, Mr. Anderson, to whom his attachment was so strong as to make him say,-- "No event which took place during the journey ever threw the smallest gloom over my mind till I laid Mr. Anderson in the grave. I then felt myself as if left a second time lonely and friendless amid the wilds of Africa." Though the party was now reduced to five Europeans, one of whom was deranged, and though the most gloomy anticipations could not fail to arise in the mind of our traveller, his firmness was in no degree shaken. He announced to Iord Camden his fixed purpose to discover the termination of the Niger, or to perish in the attempt; adding, "Though all the Europeans who are with me should die, and though I were myself half-dead, I would still persevere." To Mrs. Park he announced the same determination, combined with an undoubting confidence of success ; and the commencement of his voyage down the Niger, through the vast unknown regions of Interior Africa, he called "turning his face towards England."

It was on the 17th November, 1805, that Park set sail on his last and fatal voyage. A long interval elapsed without any tidings, which, considering the great distance and the many causes of delay, did not at first excite alarm in his friends. As the following year, however, passed on, rumours of an unpleasant nature began to prevail. Alarmed by these, and feeling a deep interest in his fate, Grovernor Haxwoll of Sierra Leone engaged Isaaco the guide, whes 
had been sent to the Gambia with despatches from the Niger, to undertake a fresh journey to inquire after him. At Sansanding, Isaaco was so far fortunate as to meet Amadi Fatouma, who had been engaged to succeed himself as interpreter. From him he received a journal purporting to contain the narrative of the voyage down the river, and of its final issue. The party, it would appear, had purchased three slaves, who, with the five Europeans and Fatouma, increased their number to nine. They passed Silla and Jenne in a friendly manner; but at Rakbara (Kabra) and Timbuctoo several armed parties came out to attack them, who were repelled only by a smart and destructive fire. No particulars are given of any of those important places; nor of Kaffo, Gotoijege, and others, which the discoverers are represented as having afterward passed. At length they came to the village (more properly city) of Yaour, where Amadi Fatouma left the party, his services having been engaged only to that point. He had, however, scarcely taken his leave, when he was summoned before the king, who bitterly complained that the white men, though they brought many valuable commodities witr them, had passed without giving him any presents. $\mathrm{He}$ therefore ordered that Fatouma should be thrown into irons, and a body of troops sent in pursuit of the English. These men reached Boussa, and took possession of a pass; where rocks, hemming in the river, allow only a narrow channel for vessels to descend. When Park arrived, he found the passage thus obstructed, but attempted, nevertheless, to push his way through. "The people began to attack him, throwing lances, pikes, arrows, and stones. He defended himself for a long time; when two of his staves at the stem of the canoe were killed. The crew threw every thing they had into the river, and kept firing; but being overpowered by numbers and fatigue, and unable to keep up the canoe against the current, and seeing no probability of escaping, Mr. Park took hold of one of the white men, and jumped into the water. Martyn did the same, and they were all drowned in the stream in attempting to escape: The only slave that remained in the boat, seeing the natives persist in throwing weapons into it without ceasing, stood up and said to them,-- Stop throwing now; you see nothing in the canoe, and nobody but 
myself; therefore cease. Take me and the canbe, but don't kill me.' They took possession of both, and carried them to the king."

These sad tidings, conveyed in course to England, were not for a long time received with general belief. The statement, being sifted with care, was thought to contain inconsistencies, as well as such a degree of improbability as left some room for hope. But, as year after year elapsed, this hope died away; and Denham and Clapperton, in their late expedition, received accounts from various quarters. which very nearly coincided with those of Amadi Fatouma. Park's adventures, they found, had excited the deepest interest throughout Africa. Clapperton in his last journey even saw the spot where he perished, which, allowing for some exaggeration, did not ill correspond with the description just given. Nay, he received notice, as we shall hereafter see, that Park's manuscripts were in the possession of the king or chief of Yaour or Youri, who offered to deliver them up on condition that the captain would pay him. a visit, which he unfortunately was never able to perform.

\section{CHAPTER $\mathrm{X}$.}

Various Travellers-Horneman, Nicholls, Roentgen, Adamss. Riley.

IT has been thought advisable to trace without interruption the interesting career of Park from its commencement to its close. Between his two expeditions, however, there intervened another, which appeared to open under very favourable auspices. Frederic Horneman, a student of the university of Grottingen, communicated to Blumenbach, the celebrated professor of natural history, his ardent desire to explore the interior of Africa under the auspices of the Association. Blumenbach transmitted to that body a strong recommendation of Horneman, as a young man, active, athletic, temperate, knowing sickness only by name, and of respectable literary and scientific attainments. Sir 
Joseph Banks immediately wrote, "If Mr. Horneman be really the character you describe, he is the very person whom we are in search of." On receiving this encouragement, Horneman immediately appliéd his mind to the study of natural history and the Arabic language, and otherwise sought to fit himself for supporting the character, which he intended to assume, of an Arab and a Moslem, under which he hoped to escape the effects of that ferocious bigotry which had opposed so fatal a bar to the progress of his predecessors.

In May, 1797, Horneman repaired to London, where his appointment was sanctioned by the Association; and having obtained a passport from the Directory, who theri governed France, he visited Paris, and was introduced to some leading members of the National Institute. He reached Egypt in September, spent ten days at Alexandria, and set out for Cairo, to wait the departure of the Rashna caravan. The interval was employed in acquiring the language of the Mograbin Arabs, a tribe bordering on Egypt. While he was at Cairo, tidings arrived of Buonaparte's having landed in that country, when the just indig* nation of the natives vented itself upon all Europeans, and among others on Horneman, who was arrested and confined in the castle. He was relieved upon the victorious entry of the French commander, who immediately set him at liberty, and very liberally offered money and every other supply which might contribute to the success of his mission. It was the 5th of September, 1793, before Horneman could find a caravan proceeding to the westward, when he joined the one destined for Fezzan. The travellers soon passed the cultivated land of Egypt, and entered on an expanse of sandy waste, such as the bottom of the ocean might exhibit if the waters were to retire. This desert was covered with the fragments, as it were, of a petrified forest ; large trunks, branches, twigs, and even pieces of bark, being scattered over it. Sometimes these stony remains were brought in by mistake as fuel. When the caravan halted for the night, each individual dug a hole in the sand, gathered a few sticks, and prepared his victuals after the African fashion of kouskous, soups, or puddings. Horneman, according to his European habits, at first employed the sertices of another; but finding himself thus exposed to conK 
tempt or suspicion, he soon followed the example of thes rest, and became his own cook.

There are as usual oases, or verdant spots, in this im. mense waste. Ten days brought the caravan to Ummesogeir, a village situated on a rock, with a hundred and twenty inhabitants, who, separated by such immense deserts from the rest of the world, pass a peaceful and hospitable life, subsisting on dates, the chief produce of their arid soil.

Another day's journey brought them to Siwah, a much more extensive oasis, the rocky border of which is estimated. by Horneman to be fifty miles in circumference. It yields, with little culture, various descriptions of grain and vegetables; but its wealth consists chiefly in large gardens of dates, baskets of which fruit form here the standard of value. The government is vested in a very turbulent aristocracy of about thirty chiefs, who meet in council in the vicinity of the town-wall, and, in the contests which frequently arise, make violent and sudden appeals to arms. The chief question in respect to Siwah is, whether it does or does not comprise the site of the celebrated shrine of Jupiter Ammon - that object of awful veneration to the nations of antiquity, and which Alexander himself, the greatest of its heroes, underwent excessive toil and peril to visit and to associate with his name. This territory does in fact contain springs, a small edifice with walls six feet thick, partly painted and adorned with hieroglyphics. There are also antique tombs in the neighbouring mountains ; but as the subsequent discoveries of Belzoni and Edmonston have proved that all these features exist in other oases scattered in different directions along the desert borders of Egypt, some uncertainty must perhaps for ever rest on this curious question.

The route now passed through a region still indeed barren, yet not presenting such a monotonous plain of sand as intervenes between Egypt and Siwah. It was bordered by precipitous limestone rocks, often completely filled with shells and marine remains. The caravan, while proceeding along these wild tracts, were alarmed by a tremendous braying of asses; and, on looking back, saw several hundreds of the people of Siwah armed and in full pursuit, mounted on these useful animals. The scouts, however, soon brought an assurance that they came with intentions perfectly peaceable, having merely understood that in the 
earavan there were two Christians from Cairo; on being allowed to kill whom, they would permit the others to proceed unmolested. All Horneman's address and firmness were required in this fearful crisis. He opposed the most resolute denial to the assertions of the Siwahans; he opened the Koran, and displayed the facility with which he could read its pages; he even challenged his adversaries to answer him on points of Mohammedan faith. His companions in the caravan, who took a pride in defending one of their members, insisted that he had cleared himself thoroughly from the imputation of being an infidel; and as they were joined by several of the Siwahans, the whole body finally renounced their bloody purpose, $\bullet$ and returned home.

The travellers next passed through Augila, a town so ancient as to be mentioned by Herodotus; but now small, dirty, and supported solely by the passage of the inland rade. They then entered the Black Harutsch, a long range of dreary mountains (Mons Ater of the ancients), through the successive defiles of which they found only a narrow tract enclosed by rugged steeps and obstructed by loose stones. Every valley, too, and ravine into which they looked appeared still more wild and desolate than the road itself. A gayer scene succeeded when they entered the district of limestone mountains called the White Harutsch. The rocks and stones here appeared as if glazed, and abounded in shells and other marine petrifactions, which, on being broken, had a vitrified appearance.

After a painful route of sixteen days through this solitary region, the travellers were cheered by seeing before them the Great Oasis, or small kingdom of Fezzan. Both at Temissa, the first frontier town, and at Zuila, the ancient capital, which is still inhabited by many rich merchants, they were receiived with rapturous demonstrations of joy. The arrival of a caravan is the chief event which diversifies the existence of the Fezzaners, and diffuses through the country animation and wealth. At Mourzouk, the modern capital, the reception was more solemn and pompcus. The sultan himself awaited their arrival on a small eminence, seated in an arm-chair ornamented with cloth of various colours, and forming a species of throne. Each pilgrim, on approaching the royal seat, took off his sandals, kissed 
the sovereign's hand, and took his station behind, where the whole assembly joined in a chant of pious gratitude.

F czzan, according to Horneman, has a length of 300 and a breadth of 200 miles, and is much the largest of all the oases which enliven the immense desert of northern Africa. It relieves however, in only an imperfect degree, the parched appearance of the surrounding region. It is not irrigated by a river or even a streamlet of any dimensions; the grain produced is insufficient for its small population, supposed to amount to 70,000 or 75,000 inhabitants ; and few animals are reared except the ass, the goat, and the camel. Dates, as in all this species of territory, form the chief article of land produce; but Fezzan derives its main importance from being the centre of that immense traffic which gives activity and wealth to Interior Africa. Mourzouk, in the dry season, forms a rendezvous for the caravans proceeding from Egypt, Morocco, and Tripoli to the great countries watered by the western rivers. Yet the trade is carried on less by the inhabitants themselves than by the Tibboos, the Tuaricks, and other wandering tribes of the desert, concerning whom our traveller collected some information, but less ample than Lyon and Denham afterward obtained from personal observation. Of Timbuctoo he did not learn much, Morocco being the chief quarter whence caravans proceed to that celebrated seat of African commerce. But respecting the eastern part of Soudan he received intelligence more accurate than had hitherto reached Europe. Houssa was for the first time understood to be, not a single country or city, but a region comprehending many kingdoms, the people of which are said to be the handsomest, most industrious, and most intelligent in that part of Africa, being particularly distinguished for their manufacture of fine cloths. Among the states mentioned were Kashna, Kano, Daura, Solan, Noro, Nyffee, Cabi, Zanfara, and Guba. Most or all of these were tributary to Bornou, which is decidedly the most powerful kingdom in Central Africa; and it was so regarded even before the rise of the Fellatah empire, which has caused, in this respect, a remarkable change. The Niger, according to the unanimous belief in the northern provinces, was described as flowing from Timbuctoo eastward through Houssa, and holding the same direction till it joined or rather became the Bahr-el. 
Abiad, the main stream of the Egyptian Nile. Prevalent as this belief is among the Arabs, late discoveries have proved it to be entirely erroneous; the river or rivers which water Houssa being wholly distinct from that great stream which flows through Bambarra and Timbuctoo.

Horneman, after remaining some time at Mourzouk, had resolved to join a caravan which was about to proceed southwards into the interior; when, observing that the cavalcade consisted almost wholly of black traders, any connexion or intercourse with whom was likely to afford him little favour in the eyes of the Moors, he was induced to forego this purpose,-more especially as there was the greatest reason to apprehend obstruction in passing through the country of the Tuaricks, who were then at war with Fezzan. He was informed, besides, that caravans from Bornou occasionally terminated their journey at Mourzouk, again returning south ; by which, at a future period and under more propitious circumstances, he hoped to have an opportunity of accomplishing his object. These considerations determined him to postpone his departure into the interior, resolving in the mean while, with the view of forwarding his despatches to the Association, to visit Tripoli ; where, however, he did not arrive till the 19th August, 1799, having been detained a considerable time by sickness. After remaining in this city about three months, he again returned to Mourzouk; nor was it till the 6th April, 1800, that he departed thence for the southward, in company with two shereefs, or descendants of Mohammed, who had given him assurances of friendship and protection. His letters were filled with the most sanguine hopes of success. But the lapse of two years without any tidings threw a damp on the cheering expectations thus raised in the Association and the public. In September, 1803, a Fezzan merchant informed Mr. Nissen, the Danish consul at Tripoli, that Yussuph, as Horneman had chosen to designate himself, was seen alive and well on his way to Gondasch, with the intention of proceeding to the coast and of returning to Europe. Another Moorish merchant afterward informed Mr. M'Donough, British consul at Tripoli, that Yussuph was in safety at Kashna in June, 1803, and was there highly respected as a Mussulnıan marabout or saint. Major Denham afterward learned that he had penetrated across Africa as far as Nyffe 
on the Niger, where he fell a victim, not to any hostility on the part of the natives, but to disease and the climate. A young man was even met with, who professed to be his son, though there was some doubt as to the grcunds of his claim to that character.

The Association, when their hopes from Horneman had failed, began to look round for other instruments ; and there was still a number of active and daring spirits ready to brave the dangers with which this undertaking was surrounded. Mr. Nicholls, in 1804, repaired to Calabar, in the Gulf of Benin, with the view of penetrating into the interior by this route, which appeared shorter than any other. He was well received by the chiefs on that coast, but could not gain much intelligence respecting the Niger, being informed that most of the slaves came from the west, and that the navigation of the river, at no great distance, was interrupted by an immense waterfall, beyond which the surface of the country became very elevated. Unfortunately, of all the sickly climates of Africa this is perhaps the most pestilential; and Mr. Nicholls, even before he had commenced his journey fell a victim to the epidemic fever.

Another German, named Roentgen, recommended also by Professor Blumenbach, undertook to penetrate into the interior of Africa by the way of Morocco. He was described as possessing an unblemished character, ardent zeal in the cause, with great strength both of mind and body. Like Horneman, he made himself master of Arabic, and proposed to pass for a Mohammedan. Having, in 1809, arrived at Mogadore, he hired two guides, and set out to join the Soudan caravan. But his career was short indeed; for soon afterward his body was found at a little distance from the place whence he set out. No information could ever be obtained as to the particulars of his death; but it was, too probably, conjectured that his guides had murdered him with the view of seizing his property.

The public mind, meantime, continued fixed with intense interest on Africa, and every channel by which even the most imperfect information respecting it could be obtained was carefully examined. Much attention was at one time excited by tidings derived even from a foreign and rather doubtful source. The African coast from Morocco to the Senegal is singularly perilous, beset with numerous sand- 
banks, and without either port or shelter. On one of these banks the American ship Charles struck on the morning of 11th October, 1810, and was so surrounded by breakers as to leave no hope of escaping a total wreck. The sailors swam ashore, but soon after daybreak were attacked by a band of Moors, a race ever on the watch for plunder. The captain was killed, apparently in consequence of rash and violent behaviour; but the crew were taken prisoners, and divided among the captors. Adams, one of the sailors, according to his own statement, was carried to the border of Bambarra, where the Moors, who, by the practice of slavestealing, had roused the hostility of the natives, were surprised, made captive, and, after four days' confinement, marched to Timbuctoo. The companions of Adams, after being presented to the king, were thrown into prison; but he himself, being regarded as a curiosity, was retained in the palace, where he became a particular favourite of the queen, who used to sit gazing at him for hours. He remained there six months, well treated, and even caressed, when a party of Moorish traders arrived, ransomed their countrymen, and Adams along with them. The caravan reached Taudeny in thirteen days; after which it was obliged to march twenty-nine days over a tract of desert, where there was neither plant nor shrub, a blade of grass, nor a drop of water. Finding the spring dry, the prospect of which had sustained their hope, they gave way to the deepest despair; some perished, and the rest dispersed in search of water. Adams, having reached Ved Duleem, fell again under the power of the wild wanderers of the desert, and was carried from place to place, suffering extreme hardships; but at length he found, at Wedinoon, three of his old shipmates, who, like himself, were immediately liberated by the humane interposition of $\mathrm{M}$. Dupuis, British consul at Mogadore. He proceeded thence to London, in the view of obtaining a passage for America, and was found in the streets of that capital by a gentleman who took a deep interest in African affairs, and who communicated the fact to Mr. Cox, secretary to the Association. Adams was then strictly examined, and his statements taken down in writing; while M.Dupuis, the consul, who happened to be in London, confirmed the general fact of the shipwreck and captivity. Hence there appeared little room to doubt the 
correctness of his relation. The remarks, however, of M. Graberg de Hemso, Swedish consul at Tripoli, lately given in the Foreign Review, seem to justify the suspicion that this narrative was in the main fictitious; that though Adams was cast ashore on the Sahara, it was in 1811 instead of 1810 , as he asserted ; that he never was south of Cape Blanco, and could not therefore have known Timbuctoo except by report. His real name, besides, was Benjamin Rose. At all events, he appears to have made diligent inquiries as to the state of the country; and his details, accordingly, as corrected by M. Dupuis, have enabled the public to form a pretty accurate opinion respecting Timbuctoo.

The picture drawn by him of this city was different from, and in many respects quite the reverse of, that hitherto presented to Europeans. There is said to exist nothing of that uncontrolled sway and fierce intolerance of the Moors, the belief of which was so strongly impressed upon Park. On the contrary, the king, and all his principal officers were negroes; the few religious ceremonies observed were pagan; and the Moors were allowed to enter the town only in small numbers, and under very rigid restrictions. This statement, which appeared at first improbable, has, however, been confirmed by subsequent accounts. The rumours that intolerance prevailed to such an extent in this seat of trade were, we may presume, exaggerated from the very first; but L'Hagi Mohammed, a resident at the well of Aroan, told M. Cahill of Rabat, that, subsequently to Mr. Park's first journey, the king of Bambarra had conquered Timbuctoo, and established there a negro government. This is confirmed by Mr. Jackson, and agrees also with the report which we shall find to be given by Riley. The description of that city, again, corresponded very little with the ideas formerly entertained of its pomp and splendour. The most spacious mansions could scarcely rank above huts, being composed of timber frames filled with earth, and only one story high; while the habitations of the lower orders were formed by putting together branches of trees, and covering them with mats made of the palmetto. Even the king's palace, or citadel, was represented as only a collection of apartments on the ground floor, enclosed by a mud wall. This, in fact, is an exact descrip- 
tion of all the African cities, where lofty structures of solid stone, in which consists the magnificence of European capitals, are totally unknown. The queen, immensely fat, was rather splendidly dressed in blue nankeen (the fine cotton cloth of the country dyed with indigo) edged with gold lace, and was lavishly ornamented with necklaces and earrings of gold. The inhabitants, like most negroes, were good-humoured, extremely gay, somewhat dissolute, and passionately fond of dancing, in which they spent great part of the night. Yet they had furious quarrels, in deciding which they employed, with desperation, not the fist only, but even the teeth. Slaves, the commodity always most eagerly sought after by the Moors, were procured by those marauding expeditions which are the disgrace and scourge of Central Africa. The citizens were accustomed to set out.monthly in parties of from one to five hundred, and usually returned with a large supply. Slavery is, moreover, the punishment for all offences of great magnitude, though it is not very frequently inflicted.

James Riley, supercargo of the American brig Commerce, sailing from Gibraltar to the Cape de Verd Islands, found himself suddenly involved in fog and tempest. On the 28th August, 1815, the vessel ran aground in the neighbourhood of Cape Bojador. The crew, on landing, were assailed by a small band of armed natives, whose appearance indicated the utmost degree of poverty and ferocity. They began forthwith an indiscriminate plunder, emptied trunks, boxes, and casks, cut open the beds, and amused themselves with seeing the feathers fly before the wind. The sailors, in the mean while, were endeavouring to patch up their long-boat as a means of escape, but were greatly mortified, on the approach of dawn, to observe from their shattered wreck, on which they had passed a melancholy night, a much more numerous band of these merciless savages. By perfidious gestures addressed to the captain, whom they had recognised as commander, they now induced Mr. Riley to land; upon which they put their daggers to his breast. He contrived, however, by stratagem, to make his escape to the long-boat which was attached to the ship, when the crew immediately pushed out to sea, resolved to brave all the dangers of that element. Accordingly they worked a little way along the shore, incessantly employed in baling their crazy bark; but 
as the leaks increased, while provisions and water failed, Riley and his men came to the conclusion, that by remaining at sea they must perish, and on land they could do no more. They retouched the coast near Cape Barbas on the 8th September, but finding it to consist of perpendicular rocks, they walked four miles, and finally clambered up broken fragments, almost at the risk of life, ere they could reach the summit. But what a scene was there presented! Before them extended an immeasurable plain, without a shrub, plant, or a blade of grass; nothing that even for a moment could support human life. They fell to the ground, exclaiming, "Tis enough!- here we must breathe our last "' From such utter despair even the horrors of African bondage appeared almost a deliverance. Towards evening a light was descried gleaming along the waste, indicating that they were in the neighbourhood of a band of these marauders. Having waited till morning they approached the camp, and prostrated themselves in a suppliant attitude. The Arabs uttered a furious yell, and immediately engaged in a violent contest for the living booty thus unexpectedly presented. This dispute ended in a division of the sailors among the barbarians, by whom the captives were hurried in different directions into the interior of the wilderness. The sufferings of Riley were so extreme as made him almost regret the life which he had saved, till he met Sidi Hamet, a respectable caravan-merchant, who, in bargaining for his person, showed much sympathy for his situation, and undertook to conduct him to Mogadore, provided he were made sure of a good ransom. The American soon had the satisfaction of seeing two blankets, a cotton robe, and a bundle of ostrich feathers paid as the price of his liberty. He prevailed on the Mussulman also to purchase his companions; after which they set out together to cross the Desert with their master and deliverer. They had a very painful journey to perform, riding with the utmost rae pidity on the naked backs of camels, over hills of loose sand, while the air was filled with tempests of drift. Food and water being moreover very scanty, they were reduced almost to the condition of skeletons, and Riley declares that he did not ultimately weigh above ninety pounds. - His mind also was oppressed with much anxiety, as Sidi Hamet, with all his humanity, gave notice from time to time, that, 
should his expectations as to the ransom fail, he would cut all their throats. Having procured, therefore, a reed and some black liquid, Riley wrote a pathetic representation of his sufferings, addressed generally to the consuls or to any Christians who might happen to be resident at Mogadore: After eight days of dreadful suspense, a letter arrived. His emotion was too great to allow him to read it; but one of his companions found it to be from Mr. Willshire, the English consul, expressed in the most sympathizing terms, and with an assurance that the ransom would be provided. This was faithfully performed; and a hospitable reception at Mogadore soon restored Riley to health and to his former dimensions.

The most interesting part of the inteligence, however, obtained on this occasion, was that communicated to Riley by Sidi Hamet, concerning his own journeys and adventures. He had accompanied a caravan to Timbuctoo, and after much exertion and suffering had arrived at the banks of the Gozen Zair, which, running eastward through Soudan, falls into the Niger. He followed its current till he reached the capital just named, which, like Adams, he described as being entirely ruled and possessed by negroes; though a smaller town, separated by a strong wall, was assigned to the Moors, who were only allowed to enter the principal city by fifties at a time. He represents Timbuctoo, on the whole; as being larger and handsomer than it had appeared to his countryman. The' shegar, or king, happened to send a caravan southward to the city of Wassanah, which Sidi Hanaet resolved to accompany. A ride of two hours brought the travellers to the banks of the $\mathrm{Zo}$ libib (Joliba of Park, and our Niger). Its course for six days was nearly due east, when it turned to the south-east, and continued to flow in that direction during the remainder of their journey. At length, after travelling in all about sixty days, they arrived at Wassanah, which appeared to Sidi Hamet a city twice as large as Timbuctoo. The inhabitants were pagans, but honest, hospitable, and kindhearted. Oleebo, the king, lived in a large and lofty palace, had 150 wives, 10,000 slaves, and a very large army. But the chief interest was excited by a report received from the king's brother, of expeditions which were sent down the river, consisting of numerous boats with large cargoes. 
of slaves. They were described as sailing two monthi, first south and then west, till they came to the great water, where they met pale people with large boats, and guns which made a noise like thunder. This relation was eagerly embraced as favouring the supposition of the Niger being the same river with the Congo or Zaire; and it may even be adduced to support the hypothesis which now identifies it with the river of Benin. The south-east and southerly course assigned to the Niger, as well as the assertion that it flowed among rocks and formed cataracts, having been since found to be correct, though contrary to the ideas then prevalent in Europe, are facts which afford reasonatle ground to believe that this journey was not altogether a romance. It is not easy, however, to conjecture what was the city described by Sidi Hamet under the name of Wassanah.

\section{CHAPTER XI.}

Government Expeditions-Tuckey, Campbell; Laing, Gray, Ritchie, and Lyon.

Thк fate of Park, notwithstanding the deep regret which it had excited in England and in Europe, presented nothing which could destroy the hope of future success. The chief cause of failure could be easily traced to the precipitation into which he had been betrayed by a too ardent enthusiasm. Nothing had even been discovered adverse to the hypothesis which identifies the Niger with the Congo, and which stil! retained a strong hold on the public mind. The views of government and of the nation on this subject were entirely in unison. It was therefore determined that an expedition on a great scale should be fitted out, divided into two portions-one to descend the Niger, and the other to ascend the Congo; which two parties, it was fondly hoped, would effect a triumphant meeting in the middle of the great stream that they were sent to explore. The public loudly applauded this resolution; and never, perhaps, 
did a military or naval armament, by which the most splendid victories were expected to be achieved, excite a deeper interest than this, which seemed destined to triumph over the darkness that had so long enveloped the vast interior of the African continent.

The expedition to the Congo was intrusted to Captain Tuckey, an officer of merit and varied services, and who had published several works connected with geography and navigation. Besides a crew of about fifty individuals, including marines and mechanics, he was accompanied by Mr. Smith, an eminent botanist, who likewise possessed some knowledge of geology; Mr. Cranch, a self-taught but able zoologist ; Mr. Tudor, a good comparative anatomist; Mr. Lockhart, a gardener from Kew ; and Mr. Galwey, an intelligent person who volunteered to join the party. They sailed from Deptford on the 16th February, 1816, and reached Malemba on the 30th June, where they met with a most cordial reception from the mafook, or king's merchant, in the belief that they were come to make up a cargo of slaves. The ehiefs, on being reluctantly convinced of the contrary, burst into the most furious invectives against the crowned heads of Europe, particularly our own most graeious sovereign, whom they denominated " the Devil," imputing chiefly to him the stop put to this odious but lucrative traffic. A few days thereafter brought the English into the channel of the Congo; which, to their great surprise, instead of exhibiting the stupendous magnitude they had been taught to expect, scarcely appeared a river of the second class. The stream, it is true, was then at the lowest, but the depth being still rnore than 150 fathoms, made it impossible to estimate the mass of water which its ehannel might convey to the ocean. The banks were swampy, overgrown with mangrove trees; and the deep silence and repose of these immense forests made a solemn impression upon the mind. At Embomma, the emporium of the Congo, much interest was excited by the discovery that a negro officiating as cook's mate was a prince of the blood. He was welcomed with rapture by his father, and with a general rejoicing by the whole village. The young savage was soon arrayed in full African pomp, having on an embroidered coat very much tarnished, a silk sash, and a black glazed-hat, surmounted by an enormous feathe 
Captain Tuckey was introduced to the chenoo, who, with his huge gilt buttons, stockings of pink sarsenet, red halfboots, and high-crowned embroidered hat, reminded him of punch in a puppet-show. It was vain to attempt to convey to this sage prince any idea of the objects of the expedition. The terms which express science and an enlightened curiosity did not excite in his mind a single idea, and he rang continual changes on the questions, "Are you come to trade?" and "Are you come to make war?"- unable to conjecture any other motive. At length, having received a solemn declaration that there was no intention to make war, he sealed peace by the acceptance of a large present of brandy.

After sailing between ridges of high rocky hills, the expedition came to the Yellala, or Great Cataract; and here they met with a second disappointment. Instead of another Niagara, which general report had led them to expect, they saw only " a comparative brook bubbling over its stony" bed." The fall appears to be occasioned merely by masses of granite, fragments of which have fallen down and blocked up the stream. Yet this obstruction rendered it quite impossible for the boats to pass ; nor could they be carried across the precipices and deep ravines by which the country was intersected. The discoverers were therefore obliged: to proceed by land through this difficult region, which, without a guide on whom they could rely, was attended with overwhelming toil. Cooloo, Inga, and Mavoonda, the principal villages, were separated by wide intervals, which placed the travellers under the necessity of often sleeping in the open air. At length the country began to improve and become more level, the river to widen, while the obstacles: to its navigation gradually disappeared. But just as the voyage began to assume a prosperous aspect, indications: of its fatal termination were already perceptible. The health of the party was rapidly giving way under the effects of fatigue, as well as the malignant influence of a damp and burning atmosphere. Tudor, Cranch, and Galwey were successively obliged to return to the ship. Captain Tuckey, after struggling for some time against the increasing pressure of disease and exhaustion, as well as the accumulating difficulties of the undertaking, saw the necessity of putting a stop to the farther progress of the expedition. Mr. Smith at first expressed deep disappointment at this resolution, 
but soon became so ill that he could scarcely be conveyed to the vessel. On reaching it, a sad scene awaited the survivors. Cranch, Tudor, and Galwey were no more; they had successively sunk under the weight of disease. Mr. Smith soon shared their fate; and Captain Tuckey himself, on the 4th October, added one more to the number of deaths, without having suffered the usual attack of fever. He had been exhausted by constant depression and mental anxiety.

From this unhappy expedition, however, some information was obtained respecting a part of Africa which had not been visited for several centuries. No trace, indeed, was seen of the great kingdoms, or of the cities and armies described by the Portuguese missionaries; so that, though the interior may very probably be more populous than the banks of the river, there must, in these pious narratives, have been much exaggeration. The largest towns, or rather villages, did not contain above a hundred houses, with five or six hundred inhabitants. They were governed by chenoos, or hererlitary chiefs, having a power nearly absolute, and by mafooks under them, who were chiefly employed in the collection of revenue. The people are merry, idle, goodhumoured, hospitable, and liberal, with rather an innocent and agreeable expression of countenance. The greatest blemish in their character appears in the treatment of the female sex, on whom they devolve all the laborious duties of life, even more exclusively than is usual among negro tribes; holding their virtue also in such slender esteem, that the greatest chiefs unblushingly made it an object of traffic. Upon this head, however, they have evidently learned much evil from their intercourse with Europeans. - The character of the vegetation, and the general aspect of nature, are pretty nearly the same on the Congo as on the other African rivers.

Meantime the other part of the expedition under Major Peddie, whose destination it was to descend the Niger, arrived at the mouth of the Senegal. Instead of the beaten track along the banks of that river, or of the Gambia, he preferred the route through the country of the Foulahs, which, though nearer, was more difficult and less explored. On the 17th November, 1816, he sailed from the Senegal, and on 14th December, the party, consisting of 100 men and 200 animals, landed at Kakundy, on the Rio Nunez; 
but before they could begin their march, Major Peddie was attacked with fever and died. Captain Campbell, on whom the command devolved, proceeded in the line proposed, till he arrived at a small river called the Panietta, on the frontier of the Foulah territory. By this time many of the beasts of burden had sunk, and great difficulty. was found in obtaining a sufficient supply of provisions. The king of the Foulahs, on being asked for permission to pass through his territories, seemed alarmed at hearing of so large a body of foreigners about to enter his country. He contrived, under various pretexts, to detain them on the frontier four months, during which their stock of food and clothing gradually diminished, while they were suffering all the evils that arise from a sickly climate and a scanty supply of necessaries. At length their situation became such as to place them under the absolute necessity of returning; and all their animals being dead, it was necessary to hire the natives to carry their baggage, - an expedient which gave occasion to frequent pillage. They reached Kakundy with the loss only of Mr. Kummer the naturalist ; but Captain Campbell, overcome with sickness and exertion, died two days after, on the 13th of June, 1817. The command was then transferred to Lieutenant Stokoe, a spirited young naval officer, who had joined the expedition as a volunteer. He formed a new scheme for proceeding into the interior; but unhappily he also sunk under the climate and the fatigues of the journey.

A sentence of death seemed pronounced against all who should attempt to penetrate the African continent; and yet there were still daring spirits who did not shrink from the undertaking. Captain Gray, of the Royal African Corps, who had accompanied the last-mentioned expedition under Major Peddie and Captain Campbell, undertook, in 1818, to perform a journey by Park's old route along the Gambia. He reached, without any obstacle, Boolibani, the capital of Bondou, where he remained from the 20th June, 1818, to the 22d May, 1819 ; but owing to the jealousy of the monarch, he was permitted to proceed no farther. With some difficulty he reached Gallam, where he met Staff-surgeon Dockard, who had gone forward to Sego to ask permission to proceed through Bambarra, - a request which had alsa been evaded. The whole party then returned to Senegal. 
In 1821, Major Laing was sent on a mission from Sierra Leone, through the Timannee, Kooranko, and Soolima countries, with the view of forming some commercial arrangements. On this journey he found reason to believe that the source of the Niger lay much farther to the south than Park had supposed. At Falaba, he was assured that it might have been reached in three days, had not the Kissi nation, in whose territory it was situated, been at war with the Soolimanas, with whom Major Laing then resided. He was inclined to fix the source of this great river a very little above the ninth degree of latitude.

The British government were, meantime, indefatigable in their endeavours to find out other channels for exploring the interior of Africa. The bashaw of Tripoli, though he had usurped the throne by violent means, showed a disposition to improve his country by admitting the arts and learning of Europe ; while the judicious conduct of Consul Warrington inclined him to cultivate the friendship of Britain. Through his tributary kingdom of Fezzan he held close and constant communication with Bornou and the other leading states of Central Africa; and he readily undertook to promote the views of any English expedition which might proceed in that direction. Such an opportunity was not to be lost. The usual means were supplied by the ministry, and the ordinary inducements held forth by the Association. Mr. Ritchie, a young man of scientific acquirements and zeal for discovery, undertook the direction of this adventure. Captain Marrayat of the navy proposed to accompany him; but, being prevented by private considera. tions, his place was taken by Lieutenant Lyon, who, as a naval officer, was expected to be useful in navigating the Niger when the party should reach that river. The mission were perfectly well received at Tripoli, and set out on the 22d March, 1819, for Fezzan, with Mukni, the sultan, who gave them the most solemn assurances of protection. This chief, however, was a ruffian, who had made his way to power by the massacre of the late sovereign and his brother, and who supported his favour at Tripoli by annual slave-hunts, which he extended over the whole Desert to the frontier of Soudan. Thus he brought annually to Tripoli 4000 or 5000 of those unhappy victims, a large proportion of whom were bestowed in presents to his liege lord. Unde? L 2 
such guardianship the mission could not be sure of that support of which they soon stood very much in need. Mourzouk was found extremely unhealthy, being intensely hot, and surrounded by pools of stagnant water, which rendered even the natives liable to fever and ague. The members of the expedition soon felt its effects, Lieutenant Lyon being seized with dysentery, and Mr. Ritchie with bilious fever, under which they languished during the whole summer. The treacherous Mukni not only withheld all aid, but studiously prevented others from giving them assistance. At length Mr. Ritcliie, overwhelmed by disease and anxiety, died on the 20 th November, 1819 ; after which Mr. Lyon found himself without the means of penetrating farther than to the southern frontier of Fezzan. He obtained indeed a good deal of information respecting the remoter countries, which, however, has been rendered less important by the fuller and more recent intelligence received through Denham and Clapperton. He passes a very unfavourable judgment upon the territory of Fezzan, which he considers nearly as barren as any part of the surrounding Desert. The cultivation is confined to a few gardens, into which water is raised by immense labour from wells of consider able depth.

\section{CHAPTER XII.}

\section{Journey of Denham and Clapperton.}

Noxhing could shake the determination of the British go: vernment to obtain, by some means or other, a competent degree of information respecting the unknown countries of Africa. The great favour and influence enjoyed at the court of Tripoli was still regarded as a favourable circumstance. It was chiefly due, as already observed, to the prudence and ability of Mr. Warrington, without whose advice scarcely any thing of importance was transacted. The bashaw was therefore disposed to renew his protection to any mission which Britain might șend. FFor could the protec: 
tion of any sovereign have been more efficient; for the influence of this petty prince and the terror of his name are almost unbounded in the greatest kingdoms of Central Africa. One weapon, the gun, in the hands of his troops, gives him all this superiority; for the remoter nations, from the Nile to the Atlantic, scarcely know any other arms besides the spear, the bow, and the javelin. A nusket among those tribes is an object of almost supernatural dread; individuals have been scen kneeling down before it, speaking to it in whispers, and addressing to it earnest supplications. With troops thus armed, the bashaw of Tripoli is esteemed in Northern Africa the most potent monarch on earth ; and it is a matter of surprise among the natives that he has not ere now compelled all Europe to embrace the Mohammedan faith. He could therefore assure the English, that for any but physical obstacles, they might travel as safely from Tripoli to Bornou, as from Edinburgh to London.

Under the confidence inspired by these circumstances, government prepared another expedition, and without difficulty procured a fresh band of adventurers, who undertook to brave all its perils. Major Denham, Lieutenant Clapperton of the navy, and Dr. Oudney, a naval surgeon possessing a considerable knowledge of natural history, were appointed to this service. Without delay they proceeded to Tripoli, where they arrived on the 18th November, 1821. They were immediately introduced to the bashaw, whom they found sitting cross-legged on a carpet, attended by armed negroes. After treating them to sherbet and coffee, he invited them to a hawking party, where he appeared mounted on a milk-white Arabian steed superbly caparisoned, having a saddle of crimson velvet richly studded with gold nails, and with embroidered trappings. He was preceded by six chaoushes, or officers, in white silk robes; while two favourite negro slaves, in glittering vest, light burnouse, and white turban, supported him on each side. The hunt began on the borders of the Desert, where parties of six or eight Arabs dashed forwards quick as lightning, fired suddenly, and rushed back with loud cries. The skill with which they manœuvred their steeds, whirling the long musket over their heads as they rode at full gallop, appeared quite surprising.

Although the English were personally well treated at Trip 
poli, they could not shut their eyes to the reigning barbarism. The sheik, Belgassum Khalifa, a fine old Arab, understood to be high in the favour of the bashaw, had been one evening at an elegant entertainment in the palace, when on reaching his own door a pistol-shot wounded him in the arm, and on his entering the passage a second penetrated his body. He staggered into the house, denouncing his own nephew as the author of the assassination. The murderers rushed in, and completed their crime by stabbing him seven times with their daggers, while his wife received two wounds in endeavouring to save him. The three actors in this tragedy instantly fled for protection to the British consulate; but Mr. Warrington sent notice to the bashaw, "that the murderers of Khalifa would find no protection under the flag of England." That chief, however, either privy to the crime, or disposed to wink at its commission, expressed his regret that the guilty persons had found shelter in the consulate; but added, that he could not think of violating such a sanctuary. Repeated assurance was given that he might send any force, or use any means, to drag them from be= neath a banner that never was disgraced by giving protection to assassins. The bashaw at length, ashamed of his apathy, sent sixteen stout fellows, by whom the ruffians were seized; and in less than an hour the murderers were seen hanging from the castle-walls.

The mission, fortified with recommendations to the sultan of Fezzan, now entered upon their long and dreary pil, grimage to Mourzouk, where they arrived on the 8th April, 1822. This prince received them with courtesy and affas bility, but gave himself very little trouble in making provision for the continuance of their journey. He even intimated his intention of visiting Tripoli, and the necessity of their remaining till his return. This arrangement was most disheartening; nor did they know what reliance to place in the sincerity of Boo Khalloom, a great merchant, who invited them to accompany an expedition which he was preparing for Soudan. The sultan and he soon after departed, each with large presents for the bashaw, to intrigue against one another at the court of Tripoli. After this there was scarcely a camel left in Fezzan, or any other means of prosecuting discovery. Major Denham then saw no alternative but that he himself should hasten back to Tripoli, and 
remonstrate with the bashaw on this apparent violation of his promise. After a tedious journey of twenty days, with only three attendants, he arrived, and waited on the barbarian, who received him with his usual courtesy; but, not giving that full satisfaction which was expected, the Major lost no time in setting sail for England, to lodge a complaint with his own court. This step was painfully felt by the bashaw, who sent vessel after vessel, one of which at last overtook Major Denham while performing quarantine at Marseilles, and announced that arrangements were actually made with Boo Khalloom for escorting him to the capital of Bornou. Accordingly, on the Major's return to Tripoli, he found the Arab chief already on the borders of the Desert.

This trader, who was now to be a guide to the English into the immense regions of the south, was a personage of . a very different character from what we in this country can form any idea of. The African caravan-merchant has nothing in common with that respectable class of men who, seated in counting-houses at London or Amsterdam, direct the movement of their ships over the ocean, and count the silent accumulation of their profits. He, on the contrary, must accompany his merchandise from one extremity to the other of a great continent, and across its immense deserts, the scene of much suffering, and frequently of death itself. Nor is it from a parched wilderness and a burning climate that he has most to apprehend. His path is every where beset by bands whose trade-is plunder, and who find amusement in assassination. He must therefore have his property guarded by armed men, ready to defend with their blood what his money has purchased. These followers, oeing in continual service, and exposed to frequent fighting, become practised soldiers, and are more than a match for the roving barbarians who infest the Sahara. Even the greatest princes view these merchant-chiefs with fear and jealousy ; and though they contrive to draw considerable advantage from their trade, scarcely consider the kingdom as their own while their troops are within its boundaries. The merchants, unhappily, do not confine themselves to self-defence; but, seeing robbery practised on every side against themselves, begin to retaliate, and soon find it cheaper, and, according to African ideas, not less 
honourable, to replenish their stores by plunder than by purchase. Slaves, the staple of their trade, are generally obtained by the most atroeious violence, in expeditions called ghrazzies or felateas, undertaken solely for that guilty purpose; but, by engaging in such enterprises themselves, the merchants enjoy the benefit, since they reckon it such, of paying in blood instead of money. Provided they can escape the dangers and casualties to which they are exposed, their profits are immense, the value of merchandise being somewhat more than tripled by its conveyance across the Desert. Thus a few successful journeys enable a man to acquire a fortune almost princely, and a high degree of influence in the Barbary States. In short, the merchant, the warrior, the prince, the thief, are united in this extraordinary character ; and he is prepared, according to circumstances, to act in one or in all of these capacities. Yet Boo Khalloom might be reckoned a good specimen of this evil race. He possessed an enlarged and liberal mind, and was honourable, and even humane, so far as a slave-merchant could retain these qualities; he was dragged, too, with reluctance into the most odious parts of his vocation, -while at home his generosity was such as to make him almost idolized.

Under the guidance of this remarkable personage Major Denham set forth, with almost the full assurance of reaching those depths of Africa from which no European had ever yet returned. Little occurred to diversify the usual monotony of a desert route, till they arrived at Sockna, where Boo Khalloom, who was fond of display, determined to make his entrance with almost kingly pomp. He rode a white Tunisian horse, with gilded saddle and trappings of scarlet cloth bordered with gold; his dress consisted of various caftans and robes of the richest silks, adorned with gold buttons, lace, and embroidery : the burnouse, a present from the bashaw, had cost 400 dollars. The citizens meeting the party with shouts and guns, and the females with singing and dancing, formed a species of triumphal procession. Several days were spent at Sockna, Boo Khalloom being ill, and wishing to try the effect of various charms and superstitious remedies. The English, meantime, witnessed a great marriage ceremony, the chief pomp of which consisted in placing the bride in a basket on the back of a 
camel and leading her round the town, while numerous horsemen galloped up and discharged their muskets quite close to her head; the honour of which compliment was understood to compensate for the fear which it could not fail to occasion.

In journeying onwards to Mourzouk the travellers passed along the naked sides of the Gebel Assoud, which the Major crossed now for the third time; but no familiarity could relieve the sense of dreariness and misery which its aspect occasioned. A rainy day came as a blessing to the whole party, especially to the poor slaves, on whom Boo Khalloom had only in special kindness bestowed one draught of water in the day to cool their burning thirst. On the 30th October the caravan made its entry into Mourzouk with similar pomp as into Sockna, amid the shouts of the inhabitants, whom the chief, by his liberality, had inspired with the warmest attachment. The Major, however, was much disheartened by not seeing any of his countrymen amid the joyous crowd; and his fears were confirmed by finding Dr. Oudney just recovering from a severe attack in the chest, and Mr. Clapperton in bed the fifteenth day with ague, facts which, combined with the unfortunate result of the last expedition and the sickly look of the natives themselves, indicated some peculiarly baneful influence, without any tisible cause, in the climate of Mourzouk.

Invalids so severely afflicted were not very fit to begin a long and laborious journey; but their ardour was extreme, and imagining that a change of air would be beneficial, they eontrived, even before Boo Khalloom was ready to set out, to move forward to Gatrone, leaving Major Denham behind at Mourzouk. On the 29th November the whole caravan broke up from that city, and began their journey through the Desert. They were escorted by nearly every inhabitant who could muster a horse. The expedition, besides the English, comprised 210 Arabs, ranged in tens and twenties, ander different chiefs. The most numerous were the M'Garha, who, to the amount of seventy, came from the barren shore of the Syrtes. These barbarians enlivened the route by their traditionary tales, their songs, their extemporary poems, in which all the incidents of the journey itself were narrated; in short, by an inexhaustible fund of wit and vivacity. Their pride, their revenge, their rob- 
beries, did not come into view in their intercourse with the English, who, being received into their camp, having eaten of their bread and salt, and being bound in the cord of friendship, were entitled to all the rights of hospitality, and would have been protected even at the hazard of life.

The caravan arrived in due time at Traghan, a small town containing a fine carpet-manufactory, and ruled by a marabout, who used the sanctity of his character to maintain order and promote the prosperity of the place. Passing that station they were soon in the heart of the Desert, where they spent whole days without seeing a living thing, even a bird or an insect, that did not belong to the caravan itself. After painful marches under the direct action of the solar rays, they were delighted by the stillness and beauty of the night. The moon and stars shone with peculiar brilliancy ; cool breezes succeeded to the burning heat of the day; and on removing a few inches of the loose hot soil, a soft and refreshing bed was obtained. Even the tipple of the blowing sand sounded like a gentle and murmuring stream. Every noise was rendered doubly impressive by the deep stillness, as well as by an echo from the surface of the surrounding waste. The road derived a very peculiar aspect from the quantity of salt with which the soil was impregnated; the clods were often cracked so as to resemble a ploughed field; and from the sides of cavities were hanging beautiful crystals of that mineral like the finest frost-work. Sometimes the ground for several miles was glazed over, resembling a sheet of ice; but though the surface was very hard, the interior was brittle, and the salt. fell away in flakes.

The travellers had not proceeded far when the melancholy aspect of the Desert was heightened by a succession. of objects which could not be viewed without the deepest horror. The ground was strewed with the skeletons of former travellers, who had perished in the attempt to cross this extensive wilderness. These at first appeared singly, but afterward increased till they amounted to fifty or sixty in a day. At Meshroo a hundred were seen together; and near the wells at El Hammar they were found lying in countless multitudes. One forenoon, as Major Denham: was dozing on horseback, he was awakened by the sound of something crashing under his horse's feet, and on look- 
ing down, saw the animal trampling on two perfect human skeletons. A movement of one of the feet had separated the scull from the trunk, and driven it forward like a ball. In some of these remains portions of the flesh and hair were left, and even the features were still distinguishable. Two female skeletons lay closely twined together, having evidently been faithful friends, who had died in each other's arms. The Arabs gave little proof of their boasted sensibility in the utter indifference with which they viewed these dismal objects, driving about the limbs with their firelocks, passing coarse jests upon the dead, and deriding the sympathy manifested by their English companions. They told them these were only blacks, "damn their fathers,"-the barbarous prejudices arising from difference of religion and lineage having thus extinguished in their breasts every touch of human sympathy. Major Denham appears in one place to countenance the popular belief that these bodies were the remains of caravans buried beneath tempests of moving sand ; but none of his facts support this conclusion, or contradict the opinion of Browne, that such victims have in most instances perished from other causes. They were lying open and exposed, without even a covering of dust; and the catastrophe of the largest group was too well known, having been a body of slaves, the chief booty obtained by the sultan of Fezzan during his last expedition into Soudan. The troop had left Bornou without an adequate supply of provisions, which failed entirely before they approached Mourzouk. That want, or perhaps fatigue, wasthe real cause of this destruction was manifest from the fact that the sufferers were all negroes, while their Arab masters had taken care to reserve for themselves the means of reaching home.

In this route the travellers had on one side the Tibboos, on the other the Tuaricks, two native tribes, probably of great antiquity, and having no alliance with the Arab race, now so widely spread over the continent. The Tibboos were on the left, and it was through their villages that the caravan passed. These people live partly on the milk of their camels, which pick up a scanty subsistence on the few verdant spots that rise amid the Desert, partly by carrying on a small trade between Mourzouk and Bornou, in which they are so busily employed that many do not spend M 
at home more than four months in the year. They are black, though without the negro features; the men ugly, but the young females possessed of some beauty, not wholly obscured by the embellishments of coral stuck in the nose, and of oil streaming over the face. They are besides a gay, good-humoured, thoughtless race, with all the African passion for the song and the dance; which last they practise gracefully, and with movements somewhat analogous to the Grecian. This cheerfulness appears wonderful considering the dreadful calamity with which they are threatened every day. Once a year, or oftener, an inroad is made by their fierce neighbours, the Tuaricks, who spare neither age nor sex, and sweep away all that comes within their reach. The cowardly Tibboos dare not even look them in the face; they can only mounit to the top of certain steep rocks with flat summits and perpendicular sides, near one of which every village is built. They carry up with them every thing that can be removed, and this rude defence avails against still ruder assailants. The savage Tuaricks, again, were observed by Clapperton and Oudney in a journey to the westward from Mourzouk, and were found in their private character to be frank, honest, and hospitable. The females are neither immured nor oppressed, as is usual among rude and Mohammedan tribes, but meet with notice and respect; indeed, the domestic habits of this nation have much resemblance to the European. They are a completely wandering race of shepherds and robbers, holding in contempt all who live in houses and cultivate the ground; yet they are, perhaps, the only native Africans who have letters and an alphabet, which they inscribe, not on books and parchments indeed, but on the dark rocks that checker the surface of their territory; and in places where they have long resided every stone is seen covered with their writings.*

Bilma, the capital of the Tibboos, was found a mean town with walls of earth, but surrounded by numerous lakes containing the purest salt, the most valuable of all articles for the commerce of Soudan. The inhabitants, however, though deeply mortified, durst not prevent the powerful Tuaricks from lading their caravans with it, and under-

* The group in the accompanying plate consists of a Tuarick on his camel, with a male and female Tibboo standiug beside him. 



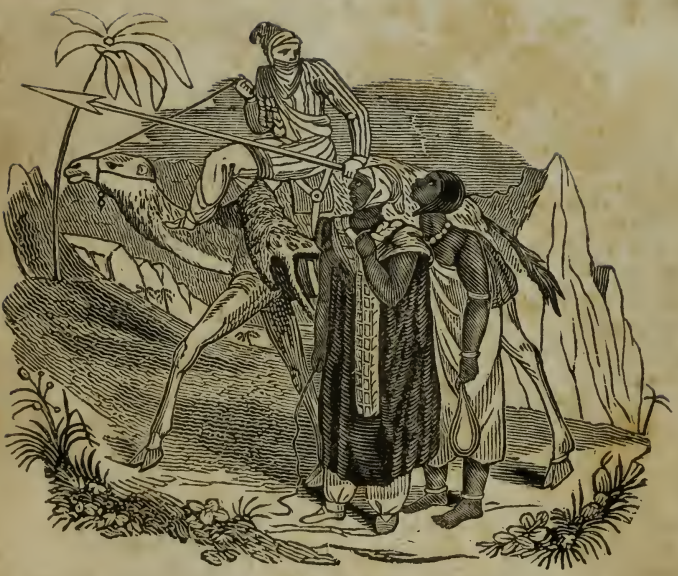

Tuarick on his Camel, with Male and Female Tibboo.-[p._134.] 
selling them in all the markets. About a mile beyond Bilma was a fine spring, spreading around, and forming a little circle of the richest verdure. This was the last vegetable life that the discoverers were to sec during a long march of thirteen days. In these wilds, where the constant drift causes hills to rise or disappear in the course of a night, all traces of a road are soon obliterated, and the eye of the traveller is guided only by dark rocks which at certain intervals raise their heads amid the sterile waste. Sometimes the sand is formed into hills with perpendicular sides, from twenty to sixty feet high. These the camelso are made to slide down; in which operation they can only be kept steady ly the driver hanging with all his weight on the tail, otherwise they would tumble fortward, and throw the load over their heads. "Tremendously dreary are these marches; as far as the eye can reach, billows of sand bound the prospect." Whenever the wind was high, volumes of this substance darkened the air, through which it was sometimes impossible to attempt a passage.

After a fortnight spent in the Desert, the expedition saw symptoms of a return to the region of life. There appeared scattered spots of thin herbage ; little valleys watered by springs were filled with the shrub called suag, on which grew delicate berries; small herds of gazelles fed in these retreats ; even the droves of hyenas indicated the revival of animal nature. As the travellers advanced, the country improved; at every mile the valleys became more gay and verdant; and the creeping vines of the colocynth in full bloom, with the red flowers of the kossom, converted many of these spots into a little Arcadia. The freshness of the air, with the melody of the hundred songsters that were perched among the creeping plants, whose flowers diffused an aromatic odour, formed the most delightful contrast to the desolate region through which they had passed. Here again were found Tibboos, of the tribe called Gunda, a more alert and active people than the former; the men still uglier, the girls still handsomer and more delicately formed. This sept have about 5000 camels, on whose milk elone they support themselves for half the year, and their horses for the whole year; the little crop of gussub and millet being too precious for these animals, which drink camels' milk, sweet or sour, and by this strange diet are 
kept in the highest health and condition. The chief, Mina Tahr, or the Black Bird, waited upon the party, and was presented by Boo Khalloom with a coarse scarlet burnouse and a tawdry silk caftan : these paltry dresses, being the finest that had ever invested the person of this chieftain, threw him into ecstasies of delight, which he continued for hours to testify by joyful shouts and high leaps into the air. Major Denham's watch singularly delighted him; but solely, as soon appeared, from the pleasure of seeing his own person in the bright metallic case; so that a very small mirror was deemed still more precious.

In this approach to the territory of Soudan the English began to witness the exercise of mutual plunder between the caravan and the natives. Every animal which straggled from the main body was instantly carried off; even a dog had been eaten up, and only the bones left. A herald, handsomely equipped, who had been sent forward to the sultan of Bornou, was found stripped, and tied naked to a tree. On the other hand, no sooner did the caravan come in view of any village than the inhabitants were descried on the plain beyond in full flight with all their effects. The Arabs pursued, in indignation only, as they pretended, at not being allowed to purchase what they wanted; but the conduct of the poor natives was evidently the result of long experience ; and Major Denham saw executed on one party the most rapid process of plunder he ever witnessed. In a few seconds the camels were eased of their loads, and the poor women and girls stripped to the skin. Boo Khalloom, on this and other occasions, interposed, and insisted on restitution; but whether he would equally have done so without the urgent remonstrances of the English appears to be doubtful.

The expedition, now advancing rapidly, entered Kanem, the most northern province of Bornou, and soon arrived at Lari, a town of two thousand inhabitants, composed of clusters of rush-huts, conical at top, and looking like wellthatched corn-stacks. This place formed a remarkable stage in their progress ; for, from the rising ground in front of it was seen stretching out the boundless expanse of the great interior sea of Africa, the lake Tchad, "glowing with the golden rays of the sun." Major Denham, who saw here the key to his grand scheme of discovery, hastened down to the shores of this mighty water. These were 


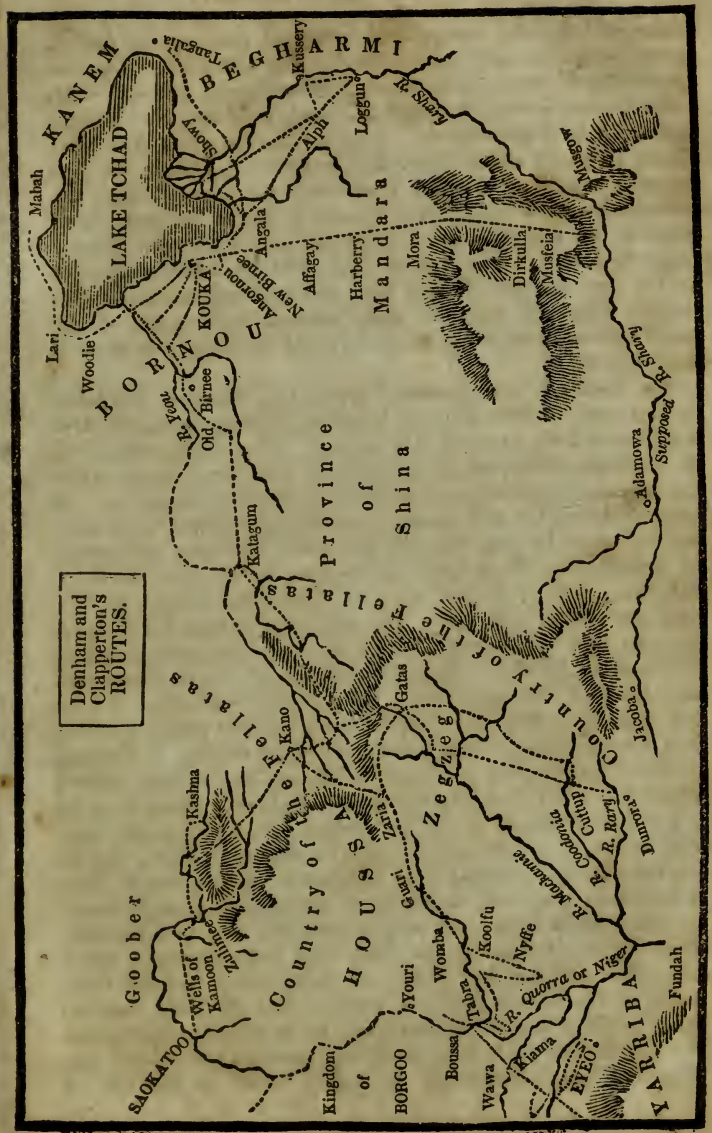


darkened with the varied and beautiful plumage of ducks, geese, pelicans, and cranes four or five feet high, immense spoonbills of snowy whiteness, yellow-legged -plovers, with numerous unknown waterfowl, sporting around, and quietly feeding at half pistol-shot. It is not to be wondered at, that Major Denham should have felt reluctant to invade the profound tranquillity of these feathered tribes, and betray the confidence with which they received him. At last, overcoming his scruples, he took up his gun, and soon filled a large basket. It was evident here, that remarkable changes in the bed of the Tchad had recently taken place; for, though this was not the rainy season, long stalks of the grain called gussub were growing amid the waters on ground formerly dry.

The caravan now marched along the shores of the lake, and arrived in two days at Woodie, a large town, the first which was found thoroughly negro. The inhabitants lived in sluggish plenty, on the produce of a fertile country, without any attempt to obtain either elegancies or luxuries. It was resolved that the caravan should pause here, till a messenger could be sent forward to obtain for them invitation, or permission, to present themselves before the sheik of Bornou. The political state of that country was at this time somewhat singular. Twenty years before it had been overrun and completely conquered, with the most dreadful devastation, by the Fellatas, a western people, to whose empire Bornou seemed to have been finally annexed. There still remained, however, a spirit in the people which spurned at a foreign yoke. The present sheik, a native of Kanem, of humble birth, but of superior talents and energy, rallied round him a band of bold spearmen, and, animating them by a pretended vision of the prophet, hoisted the green flag, and attacked the invaders. His success was such, that in ten months the Fellatas were completely driven out of Bornou, which they had never since re-entered, though desultory hostilities were still waged between the two nations. This leader, idolized by the army who had conquered under him, was now the real master of the country, yet the reverence of the nation for their ancient line of kings was too deep to allow the legitimate heir to be wholly superseded. He was drawn forth from obscurity, received the title of sultan, and was established in empty pomp at the city of 
Birnie ; while the successful soldier, under an humbler name, retained in his own hands all the real power of the kingdom.

After five days an invitation arrived from the sheik to visit him at Kouka, for which city the travellers immediately departed. In their way they passed the Yeou, the first river of any description which had crossed their path in this long journey, exciting considerable interest from being for a moment supposed to be the Niger flowing from Timbuctoo. The stream was fifty yards broad, and proceeded with some rapidity eastward into the Tchad: in the wet season its breadth became twice as great. On the bank, for the convenience of passengers, lay two large canoes, rudely put together, constructed of planks fastened by cords, and having the openings stuffed with straw. The men and goods were ferried over on these rafts, while the horses and camels, having their heads fastened to them, swam across.

In approaching Kouka Major Denham experienced considerable emotion, in consequence of the contradictory reports which he heard respecting the array and aspect of this great central court of Africa. Some told him that the sheik was surrounded by a mere handful of half-armed, halfnaked negroes, fit only for plunder; while, according to others, he was at the head of a numerous cavalry, highly equipped and well-discíplined. The Major pressed eagerly forward before the main body, and, emerging from the forest, had his curiosity gratified by seeing a body of several thousand horse drawn up in line, and extending on each side as far as the eye could reach. He now awaited the coming up of the Arabs; at sight of whom the Bornou troops, who had previously stood immoveable, raised a mighty shout or yell, which rent the air, followed by a sound equally loud of rude martial music. Then, forming detached parties, they galloped up full speed to the strangers, never pausing till they almost touched the horses' heads, when they suddenly wheeled round and returned, exclaiming, "Blessing! blessing ! sons of your country! sons of your country !" They had soon completely surrounded the party, and wedged them in so close, waving their spears over their heads, that it was impossible for the strangers to move. Boo Khalloom had nearly lost all patience at this vehement and incommodious welcome; but at length Barca Gana, the commander-in-chief, made his appearance, ro. 
stored order, and caused a way to be opened, by which the caravan, though somewhat slowly, at length made its way to the city.

But, after their arrival at Kouka, symptoms of jealousy appeared, and only twelve of the principal persons, the English included, were allowed to enter. They were led through a wide street, lined with spearmen, to the door of the sheik's residence. Here 'the principal courtiers came out in succession, and welcomed the party with cries of "Barca! Barca!" but as no one invited them to go in, the wrath of Boo Khalloom, who held himself scarcely inferior to the sheik, was kindled, and he declared that, unless immediately admitted, he would return to his tent. A chief merely waved his hand as a signal for patience; but at last Barca Gana appeared, and invited the Arab leader to enter alone. Another half-hour elapsed ere the gates were again opened, and the four Englishmen were called. They found, on the present as well as on other occasions, the etiquette of this barbarian court extremely rigid, and enforced too in a manner the most rough and unceremonious. They were allowed to walk only one by one, and, when thought to be going too fast, the guards grasped them by the leg so abruptly that they could with difficulty'avoid falling flat forward ; and when it was time to stop, instead of their being told so, spears were crossed before them, and the palm of the hand applied to their breast. At the close of all this ceremony, they found the sheik quietly seated on a carpet, plainly dressed, in a small dark room, ornamented solely with guns and pistols, which he had received in presents from crowned heads, and esteemed the most rare and precious of decorations. He appeared about forty or forty-five years of age, and his countenance was pleasing and expressive. He inquired their object in visiting Bornou; when, being informed that they had come merely to see the country, and to give an account of its appearance, produce, and people, he engaged to forward their views, and even to gratify their wishes to the utmost of his power. Such motives, however, afterward proved entirely incomprehensible to his illiterate mind.

Major Denham next day waited again on the sheik and delivered his presents. A double-barrelled gun and twr pistols, with powder-flask, and shot-cases, were exanined by the 
chief with the most minute attention; the other gifts, consisting of fine cloths, spices, and porcelain, were no sooner produced than the slaves carried them off. The African was particularly gratified on being old that the king of England had heard of him, and said, turning to his captains, "This must be in consequence of our having defeated the Begharmis ;" upon which Bagah Furby, a grim old soldier, who had made a figure in that war, came forward and asked, "Did he ever hear of me ?" Major Denham scrupled not to answer " Certainly ;" when the whole party instantly called out, "Oh! the king of England must be a great man."

The Major, in the course of his residence at Kouka, had frequent opportunities of visiting the sheik. One day he received a message that he must come instantly and exhibit a musical box playing tunes by itself, which the other understood to be in his possession. This great warrior, who had never before shown any interest unless about grave concerns, was quite enchanted on hearing its performance, and raised shouts of delight and astonishment. He examined minutely the different parts of the mechanism, declaring he would willingly give a thousand dollars in exchange for it. The Major, unable to misunderstand so broad a hint, presented the box to his highness. The display of sky-rockets also caused the utmost amazement and joy, and was even employed to strike the enemies of the sheik with superstitious awe. Finding that our traveller could speak Arabic, and give much information not attainable from any other quarter, Barca Gana became forid of his conversation, and invited him to pay frequent visits.

It remained that Major Denham should be introduced to the sultan in his royal residence at Birnie, where all the state and pomp of the kingdom, with none of its real power, were concentrated. On the 2d March, the English accompanied Boo Khalloom to that city, and, on their arrival there, the following morning was fixed for the interview. Fashion, even in the most refined European courts, does not always follow the absolute guidance of reason or taste, and her magic power is often displayed in converting deformities into beauties; but there is certainly no court of which the taste is so absurd, grotesque, or monstrous, as that to which Major Denham was now introduced. An enormous protruding belly and a huge misshapen head are the two features without which it is vain to aspire to the 
rank of a courtier or of a fine gentleman. This form, valued probably as a type of abundance and luxury, is esteemed so essential, that, where nature has not bestowed, and the most excessive feeding and cramming cannot produce it, wadding is employed, and a false belly produced, which, in riding, appears to hang over the pummel of the saddle. Turbans also are wrapped round the head, in fold after fold, till it appears swelled on one side to the most unnatural dimensions, and only one-half of the face remains visible. The factitious bulk of the lords of Bornou is still farther augmented by drawing round them, even in this burning climate, ten or twelve successive robes of cotton or silk, while the whole is covered over with numberless charms enclosed in green leather cases. Yet under all these encumbrances they do sometimes mount and take the field; but the idea of such unwieldy hogsheads being of any avail in the day of battle appeared altogether ridiculous,- and it proved accordingly, that, on such high occasions, they merely exhibited themselves as ornaments, without making even a show of encountering the enemy.

With about 300 of this puissant chivaliy before and around him, the sultan was himself seated near the gardendoor in a sort of cane basket covered with silk, and his face entirely shaded beneath a turban of more than the usual

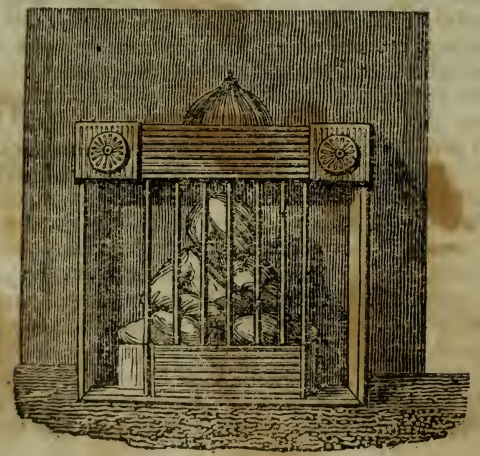


magnitude. The presents were silently deposited; nothing passed; and the courtiers, tottering beneath the weight of their turbans and their bellies, could not display that punctilious activity which had been so annoying at the palace of the sheik. This was all that was ever seen of the sultan of Bornou. The party then set out for Kouka, passing, on their way, through Angornou, the largest city in the kingdom, containing at least 30,000 inhabitants:

During his residence at Kouka and Angornou, Major Denham frequently attended the markets, where, besides the proper Bornouese, he saw the Shouaas, an Arab tribe, who are the chief breeders of cattle; the Kanemboos from the north, with their hair neatly and tastefully plaited; and the Musgow, a southern clan of the most savage aspect. A loose robe or shirt, of the cotton cloth of the country, often fine and beautifully died, was the universal dress; and high rank was indicated by six or seven of these worm one above another. Ornament was studied chiefly in plaiting the hair, in attaching to it strings of brass or silver beads, in inserting large pieces of amber or coral into the nose, the ear, and the lip; and when to these was added a face streaming with oil, the Bornouese belle was fully equipped for conquest. Thus adorned, the wife or daughter of rich Shouaa might be seen entering the market in full style, bestriding an ox, which she inanaged dexterously by a leathern thong passed through the nose, and whose unwieläly bulk she contrived even to torture into something like capering and curvetting. Angornou is the chief market, and the crowd there is sometimes immense, amounting often to èighty or a hundired thousand individuals. All the produce of the country is bought and sold in open miarket; for shops and warehouses do not enter into the system of African traffic. There is displayed an abundance of their principal grain, called gussub, a good deal of wheat and rice, an ample store of bullocks, and no small riumber of sheep and fowls ; but not a vegetable except à few onions, nor a single fruit of any kind, - the Bornouese not having attained to the production of these elegant luxuries. The objects most prized and rare are pieces of amber, coral, and brass, to adorn the countenances of the females; these are sold readily, and paid in money, while other articles are only exchanged for cloth. Anong other rarities are sometimes 
offered young lions, to be kept as domestic favourites. The Major found one of them enclosed by a circle of spectators, and was invited to step up and stroke it on the mane. He was about to comply, though with sensations which he admits himself unable to describe, when the animal suddenly brushed past him, broke through the circle, and rushed to another station. The sheik was afterward kind enough to send him a young lion as a pet, which the Major politely returned, expressing regret at not being able to find room for so fine a specimen of African zoology.

Bornou, taken altogether, forms an extensive plain, stretching 200 miles along the western shore of the immense lake already mentioned, and nearly the same distance inland. This sea periodically changes its bed in an extraordinary manner. During the rains, when its tributary rivers pour in thrice the usual quantity of water, it inundates an extensive tract of country, from which it retires in the dry season. This space, then overgrown with dense underwood, and with grass double the height of a man, contains a motley assemblage of wild beasts,--lions, panthers, hyenas, elephants, and serpents of extraordinary form and bulk. These monsters, while undisturbed in this mighty den, remain tranquil, or war only with each other; but when the lake swells, and its waters rush in, they of necessity seek refuge among the abodes of men, to whom they prove the most dreadful scourge. Not only the eattle, but the slaves tending the grain, often fall victims; they even rush in large bodies into the towns. The rest of the country, placed beyond the reach of this annual inundation, is in many places very fertile; and cultivation is so limited that land may always be had in any quantity by him who has slaves to employ upon it. This service is performed by female captives from Musgow, who, aiding their native ugliness by the insertion of a large piece of silver into the upper-lip, which throws it entirely out of shape, are coveted in no other view than for the quantity of hard work which they can execute. The processes of agriculture are extremely simple. Their only fine manufacture is that of tobes, or vestments of cotton skilfully woven and beautifully died, but still not equal to those of Soudan. In every other handicraft they are very inexpert, - even in works of iron, which are of the greatest use to a martial people. 
The Bornouese have, however, an ingenious mode, represented in the accompanying plate, of fishing with a very

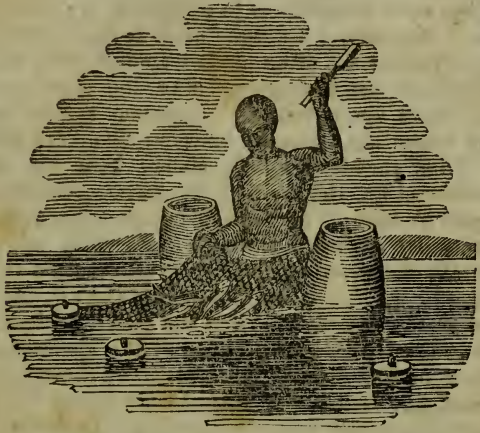

simple apparatus. They take two large gourds; and fasten them at each end to a stem of bamboo. The fisherman seats himself upon this machine, floats with the current, and throws his net. On drawing it up, he lays it before him, stuns the fish with a species of mace, and piles them into the gourds. They are afterward dried, and conveyed over the country to a considerable distance.

The Bornouese are complete negroes both in form and feature ; they are ugly, simple, and good-natured, but destitute of all intellectual culture. Only a few of the great fighis, or doctors, of whom the sheik was one, can read the Koran. A "great writer," indeed, is held in still higher estimation than with us; but his compositions consist only of words written on scraps of paper, to be enclosed in cases, and worn as amulets. They are then supposed to defend their possessor against every danger, to act as charms to destroy his enemies, and to be the main instrument in the cure of all diseases. - For this last purpose they are aided only by a few simple applications ; yet the Bornou practice is said to be very successful, either through the power of imagination, or owing to their excellent constitutions. In 
the absence of all refined pleasures, various rude sports are pursued with eagerness, and almost with fury. The most favourite is wrestling, which the chiefs do not practise in person, but train their slaves to exhibit in it as our jockeys do game-cocks, taking the same pride in their prowess and victory. Nations are often pitched against each other, the Musgowy and the Begharmi being the most powerful. Many of them are extremely handsome and of gigantic size, and hence the contests between them are truly terrible. Their masters loudly cheer them on, offering high premiums for victory, and sometimes threatening instant death in case of defeat. They place their trust, not in science, but in main strength and rapid movements. Occasionally the wrestler, eluding his adversary's vigilance, seizes him by the thigh, lifts him up into the air, and dashes him against the ground. When the match is decided, the victor is greeted with loud plaudits by the spectators, some of whom even testify their admiration by throwing to him presents of fine cloth. He then kneels before his master, who not unfrequently bestows upon him a robe worth thirty or forty dollars, taken perhaps from his own person. Death or maiming, however, is no unfrequent result of these encounters. The ladies, even of rank, engage in another very odd species of contest. Placing themselves back to back, they cause particular parts to strike together with the most violent collision, when she who maintains her equilibrium, while the other lies stretched on the ground, is proclaimed victor with loud cheers. In this conflict the girdle' of beads worn by the more opulent females very frequently bursts, when these ornaments are seen flying about in every direction. To these elegant recreations is added gaming, always the rage of uncultivated minds. Their favourite game is one rudely played with beans, by means of holes made in the sand.

Boo Khalloom, having despatched his affairs in Bornou, wished to turn his journey to some farther account, and proposed an expedition into the more wealthy and commercial region of Houssa or Soudan; but the eager wishes of his followers pointed to a different object. They called upon him to lead them into the mountains of Mandara in the south, to attack a village of the kerdies, or unbelievers, and carry off the people as slaves to Fezzan. He long 
stood out against this nefarious proposal; but the sheik, who also had his own views, took part against him; even his own brother joined the malecontents, and at length there appeared no other mode in which he could return with equal credit and profit. Influenced by these inducements, he suffered his better judgment to be overpowered, and determined to conduct his troop upon this perilous and guilty excursion. Major Denham, allowing his zeal for discovery to overcome other considerations, contrived, notwithstanding the prohibition of the sheik, to be one of the party. They were accompanied by Barca Gana, the principal general, a negro of huge strength and great courage, along with other warriors, and a large body of Bornou cavalry. These last are a fine military body in point of external appearance. Their persons are covered with iron plate and mail, and they manage, with surprising dexterity, their little active steeds, which are also supplied with defensive armour. They have one fault only, but that a serious one,- they cannot stand the shock of an enemy. While the contest continues doubtful, they hover round as spectators, ready, should the tide turn against them, to spur on their coursers to a rapid flight; but if they see their friends victorious, and the enemy turning their backs, they come forward and display no small vigour in pursuit and plunder.

The road that led to Mandara formed a continued ascent through a fertile country which contained some populous towns. The path being quite overgrown with thick and prickly underwood, twelve pioneers went forward with long poles, opening a track, pushing back the branches, and giving warning to beware of holes. These operations they accompanied with loud praises of Barca Gana, calling out, - "Who is in battle like the rolling of thunder? Barca Gana. In battle, who spreads terror around him like the buffalo in his rage ? Barca Gana." Even the chiefs on this expedition carried no provisions except a paste of rice, flour, and honey, with which they contented themselves, unless when sheep could be procured; in which case half the animal, roasted over a frame-work of wood, was placed on the table, and the sharpest dagger present was employed in cutting it into large pieces, to be eaten without bread or salt. At length they approached Mora, the capital of Mandara. 
This was another kingdom which the energy of $\mathrm{its}$ present sultan had rescued from the yoke of the Fellata empire; and the strong position of its capital, enclosed by lofty ridges of hills, had enabled it to defy repeated attacks. It consists of a fine plain, bordered on the south by an immense and almost interminable range of mountains. The eminences directly in front were not quite so lofty as the hills of Cumberland, but bold, rocky, and precipitous, and distant summits appeared towering much higher, and shooting up a line of sharp pinnacles resembling the needles of Mont Blanc. It was reported, that two months were required to cross their greatest breadth and reach the other side, where they rose ten times higher, and were called large moon mountains. They there overlooked the plain of Adamowa, through which the Quolla (or Niger) was said to flow from the westward. The hills immediately in view were thickly clustered with villages perched on their sides and even on their tops, and were distinctly seen from the plain of Mandara. They were occupied by half-savage tribes, whom the ferocious bigotry of the nations occupying the low country branded as pagans, and whom they claimed a right to plunder, seize, and drive in crowds for sale to the markets of Fezzan and Bornou. "The fires, which were visible in the different nests of these unfortunate beings, threw a glare upon the bold rocks and blunt promontories of granite by which they were surrounded, and produced a picturesque and somewhat awful appearance." A baleful joy gleamed in the visage of the Arabs as they eyed these abodes of their future victims, whom they already fancied themselves driving in bands across the Desert. A kerdy village to plunder was all their cry, and Boo Khalloom doubted not that he would be able to gratify their wishes. Their common fear of the Fellatas had united the sultan of Mandara in close alliance with the sheik, to whom he had lately. married his daughter; and the nuptials had been celebrated by a great slave-hunt among the mountains, when, after a dreadful struggle, three thousand captives, by their tears and bondage, furnished out the materials of a magnificent marriage-festival.

The expedition obtained a reception quite as favourable as had been expected. In approaching the capital they were met by the sultan with 500 Mandara horse, who, 
charging full speed, wheeled round them with the same threatening movements which had been exhibited at Bornou. The horses were of a superior breed, most skilfully managed, and covered with cloths of various colours, as well as with skins of the leopard and tiger-cat. This cavalry made of course a very brilliant appearance ; but the Major did not yet know that their yalour was exactly on a level with that of their Bornou allies. The party were then escorted to the capital, amid the music of long pipes like clarionets, and of two immense trumpets. They were introduced next day. The mode of approaching the royal residence is to gallop up to the gate with a furious speed, which often causes fatal accidents; and on this occasion a man was ridden down and killed on the spot. The sultan was found in a dark-blue tent, sitting on a mud-bench, surrounded by about two hundred attendants, handsomely arrayed in silk and cotton robes. He was an intelligent little man, about fifty years old, with a beard dyed sky-blue. Courteous salutations were exchanged; during which he steadily eyed Major Denham, concerning whom he at last inquired; and the traveller was advantageously introduced as belonging to a powerful distant nation, allies of the bashaw of Tripoli. At last, however, came the fatal question,-_" Is he Moslem ? -La! la! - no! no!- What! has the great bashaw Caffre friends?"-Every eye was instantly averted; the sun of Major Denham's favour was set; and he was never more allowed to enter the palace.

The bigotry of this court seems to have surpassed even the usual bitterness of the African tribes, and our traveller had to undergo a regular persecution, carried on especially by Malem Chadily, the leading fighi or doctor of the court. As Major Denham was showing to the admiring ehiefs the mode of writing with a pencil, and effacing it with Indian rubber, Malem wrote some words of the Koran with such force that the rubber could not wholly remove the traces of them. He then exclaimed with triumph, "They are the words of God, delivered to his prophet; I defy you to erase them." The Major was then called upon to acknowledge this great miracle ; and, as his countenance still expressed incredulity, he was viewed with looks of such mingled contempt and indignation as induced him to retire. Malem, however, again assailed him with the assurance that this 
was only one of the many miracles which he could show as wrought by the Koran ; imploring him to turn, and paradise would be his, otherwise nothing could save him from eternal fire. "Oh!" said he, "while sitting in the third heaven I shall see you in the midst of the flames, crying out to your friend Barca Gana and myself for a drop of water; but the gulf will be between as :" his tears then flowed profusely. The Major, taking the general aside, entreated to be relieved from this incessant persecution; but Gana assured him that the fighi was a great and holy man, to whom he ought to listen. He then held out not only paradise, but honours, slaves, and wives of the first families, as gifts to be lavished on him by the sheik if he would renounce his unbelief. Major Denham asked the commander, what would be thought of himself if he should go to England and turn Christian? "God forbid!" exclaimed he ; "but how can you compare our faiths ; mine would lead you to paradise, while yours would bring me to hell. Not a word more."-Nothing appears to have annoyed the stranger more than to be told that he was of the same faith with the kerdies or savages; little distinction being made between any who denied the Koran. After a long discussion of this question, he thought the validity of his reasoning would be admitted, when he could point to a party of those wretches devouring a dead horse, and appealed to Boo Khalloom if he had ever seen the English do the same; but to this, which was not after all a very deep theological argument, the Arab replied,- "I know they eat the flesh of swine, and, God knows, that is worse."- "Grant me patience," exclaimed I to myself,- " this is almost too much to bear and to remain silent."

The unfortunate kerdies, from the moment that they saw Arab tents in the valley of Mandara, knew the dreadful calamity which awaited them. 'To avert it, and to propitiate the sultan, numerous parties came down with presents of honey, asses, and slaves. Finally appeared the Musgow, a more distant and savage race, mounted on small fiery steeds, covered only with the skin of a goat or leopard, and with necklaces made of the teeth of their enemies. They threw themselves at the feet of the sultan, casting sand on their heads, and uttering the most piteous cries. The monarch, apparently moved by these gifts and 
entreaties, began to intimate to Boo Khalloom his hopes that these savages might by gentle means be reclaimed and led to embrace the true faith. These hopes were held by the latter in the utmost derision; and he privately assured Major Denham that nothing would more annoy this devout Mussulman than to see them fulfilled, whereby he must nave forfeited all right to drive these unhappy creatures in crowds to the markets of Soudan and Bormou. In fact, ooth the sultan and the sheik had a much deeper aim. Every effort was used to induce Boo Khalloom to engage in the attack of some strong Fellata posts, by which the country was hemmed in; and as the two monarchs viewed the Arabs with extreme jealousy, it was strongly suspected that their defeat would not have been regarded as a public calamity. The royal councils were secret and profound, and it was not known what influences worked upon Boo Khalloom. On this .occasion unfortunately he was mastered by his evil genius, and consented to the proposed attack ; but as he came out and ordered his troops to prepare for marching, his countenance bore such marks of trouble that the Major asked if all went well ? to which he hurriedly answêred, "Please God." The Arabs, however, who at all events expected plunder, proceeded with alacrity.

The expedition set out next morning, and, after passing through a beautiful plain, began to penetrate the mighty chain of mountains which form the southern border of the kingdom. Alpine heights, rising around them in rugged magnificence and gigantic grandeur, presented scenery which our traveller had never seen surpassed. The passes of Hairey and of Horza, amid a superb amphitheatre of hills, closely shut in by overhanging cliffs, more than two thousand feet high, were truly striking. Here, for the first time in Africa, did nature appear to the English to revel in the production of vegetable life. The trees were covered with luxuriant and bright green foliage ; and their trunks were hidden by a crowd of parasitical plants, whose aromatic blossoms perfumed the air. There was also an abundance of animal life of a less agreeable description : three scorpions were killed in the tent; and a fierce but beautiful panther, more than eight feet long, just as he had gorged himself by sucking the blood of a newly-killed negro, was attacked and speared. The sultan and Barca Gana 
were attended by a considerable body of Bornou and Mandara cavalry, whose brilliant armour, martial aspect, and skilful horsemanship gave confidence to the European officer, who had not yet seen them put to the proof.

It was the third day when the expedition came in view of the Fellata town of Dirkulla. The Arabs, supported by Barca Gana and about a hundred spearmen, marched instantly to the attack, and carried first that place, and then a smaller town beyond it, killing all who had not time to escape. The enemy, however, then intrenched themselves in a third and stronger position, called Musfeia, enclosed by high hills, and fortified in front by numerous swamps and palisades. This was likewise attacked, and all its defences forced. The guns of the Arabs spread terror, while Barca Gana threw eight spears with his own hand, every one of which took effect. It was thought, that had the two bodies of cavalry made even a show of advancing, the victory would have been at once decided; but Major Denham was much surprised to see those puissant warriors keeping carefully under cover behind a hill on the opposite side of the stream, where not an arrow could reach them. The Fellatas, seeing that their antagonists were only a handful, rallied on the tops of the hills, were joined by new troops, and turned round. Their women behind, cheering them on, continually supplied fresh arrows, and rolled down fragments of rock on the assailants. These arrows were fatal; they were tipped with poison, and wherever they pierced the body in a few hours became black, blood gushed from every orifice, and the victim expired in agony. The condition of the Arabs soon became alarming; scarcely a man was left unhurt, and their horses were dying under them. Boo Khalloom and his charger were both wounded with poisoned arrows. As soon as the Fellatas saw the Arabs waver, they dashed in with their horse ; at sight of which all the heroic squadrons of Bornou and Mandara put spurs to their steeds, the súltan at their head, and the whole became one mass of confused and tumultuous flight. Major Denham saw too late the peril into which he had wantonly plunged. His horse, pierced to the shoulder-bone, could scarcely support his weight; but the cries of the pursuing Fellatas still urged him forward. At last the animal fell twice, and the second time threw him against a tree, then, 
frightened by the noise behind, started up and ran off. The Fellatas were instantly up, when four of his companions were stabbed beside him, uttering the most frightful cries. He himself was fully prepared for the same fate; but happily his clothes formed a valuable booty, through which the savages were loath to run their spears. After inflicting some slight wounds, therefore, they stripped him to the skin, and forthwith began to quarrel about the plunder. While they were thus busied, he contrived to slip away, and though hotly pursued, and nearly overtaken, succeeded in reaching a mountain-stream gliding at the bottom of a deep and precipitous ravine. Here he had snatched the young branches issuing from the stump of a large overhanging tree, in order to let himself down into the water, when, beneath his hand, a large liffa, the most dangerous serpent in this country, rose from its coil, as in the very act of darting upon him. Struck with horror, Major Denham lost all recollection, and fell headlong into the water; but the shock revived him, and, with three strokes of his arm, he reached the opposite bank, and felt himself for the moment in safety. Running forward, he was delighted to see his friends Barca Gana and Boo Khalloom; but amid the cheers with which they were endeavouring to rally their troops, and the cries of those who were falling under the Fellata spears, he could not for some time make himself heard. Then Maramy, a negro appointed by the sheik to attend on him, rode up and took him on his own horse. Boo Khalloom ordered a burnouse to be thrown over him,very seasonably, for the burning sun had begun to blister his naked body. Suddenly, however, Maramy called out, "See, see! Boo Khalloom is dead!" and that spirited chief, overpowered by the wound of a poisoned arrow, dropped from his horse, and spoke no more. The others now thought only of pressing their flight, and soon reached a stream, where they refreshed themselves by copious draughts, and a halt was made to collect the stragglers. Major Denham here fell into a swoon; during which, as he afterward learned, Maramy complained that the jaded horse could scarcely carry the stranger forward, when Barca Gana said,-_"By the head of the prophet! believers enough have breathed their last to-day; why should we concern urselves about a Christian's death ?" Malem Chadily, 
however, so bitter as a theological opponent, showed now the influence of a milder spirit, and said,- "No, God has preserved him; let us not abandon him;" and Maramy declared,- "His heart told him what to do." They therefore moved on slowly till about midnight, when they passed the Mandara frontier in a state of severe suffering; but the Major met with much kindness from a dethroned prince, Mai Meegamy, who, seeing his wounds festering under the rough woollen cloak which formed his only covering, took off his own trousers and gave them to him.

The Arabs had lost forty-five of their number, besides their chief; the rest were in a miserable plight, most of them wounded, some mortally, and all having lost their camels and the rest of their property. Renouncing their pride, they were obliged to supplicate from Barca Gana a handful of corn to keep them from starving. The sultan of Mandara, in whose cause they had suffered, treated them with the utmost contumely, which perhaps they might deserve, but certainly not from him. Deep sorrow was afterward felt in Fezzan when they arrived in this deplorable condition and reported the fall of their chief, who was there almost idolized. A national song was composed on the occasion, which the following extract will show to be marked by great depth of feeling, and not altogether devoid of poetical beauty :-

"Oh! trust not to the gun and the sword! The spear of the unbeliever prevails?

"Boo Khalloom, the good and the brave, has fallen! Who shall now be safe? Even as the moon among the little stars, so was Boo Khalloom among men! Where shall Fezzan now look for her protector? Men hang their heads in sorrow, while women wring their hands, rending the air with their cries! As a shepherd is to his flock, so was Boo Khalloom to Fezzan!

"Give him songs! Give him music! What words can equal his praise? His heart was as large as the desert ! His coffers were like the rich overflowings from the udder of the she-camel, comforting and nourishing those around him!

"Even as the flowers without rain perish in the fields, so will the Fezzaners droop; for Boo Khalloom returns no more! 
"His body lies in the land of the heathen! The poisoned arrow of the unbeliever prevails !

"Oh! trust not to the gun and the sword! The spear of the heathen conquers! Boo Khalloom, the good and the brave, has fallen! Who shall now be safe?"

The sheik of Bornou was cronsiderably mortified by the result of this expedition, and the miserable figure made by his troops, though he sought to throw the chief blame on the Mandara part of the armament. He now invited the Major to accompany an expedition against the Mungas, a rebel tribe on his outer border, on which oceasion he was to employ his native band of Kanemboo spearmen, who, he trusted, would redeem the military reputation of the monarchy. Major Denham was always ready to go wherever he had a chance of seeing the manners and scenery of Africa. The sheik took the field, attended by his armourbearer, his drummer fantastically dressed in a straw hat with ostrich feathers, and followed by three wives, whose heads and persons were wrapped up in brown silk robes, and each led by a eunuch. He was preceded by five green and red flags, on each of which were extracts from the Koran, written in letters of gold. Etiquette even required that the sultan should follow with his unwieldy pomp, naving a harem, and attendance much more numerous; while frumfrums, or wooden trumpets, were continually sounded before him. This monarch is too dignified to fight in person; but his guards, the swollen and overloaded figures formerly described, enveloped in multiplied folds, and groaning beneath the weight of ponderous amulets, produced themselves as warriors, though manifestly unfit to face any real danger.

The route lay along the banks of the river Yeou, called also Gambarou, through a country naturally fertile and delightful, but presenting a dismal picture of the desolation occasioned by African warfare. The expedition passed through upwards of thirty towns, completely destroyed by the Fellatas in their last inroad, and of which all the inhabitants were either killed or carried into slavery. These fine plains were now overgrown with forests and thickets, in which grew tamarind and other trees, producing delicate fruits; while large bands of monkeys, called hy Arabs " enchanted men," filled the woods with their cries. 
Here, too, was found Old Birnie, the ancient but now desolate capital, evidently much larger than any of the present cities, covering five or six miles with its ruins. They passed also Gambarou, formerly the favourite residence of the sultans, where the remains of a palace and of two mosques gave an idea of civilization superior to any thing that had yet been seen in Interior Africa. There were left in this country only small detached villages, the inhabitants of which remained fixed to them by local attachment, in spite of constant predatory inroads by the Tuaricks, who carried off their friends, their children, and cattle. They have recourse to one mode of defence, which consists in digging a number of blaquas, or large pits: these they cover with a false surface of sods and grass, into which the Tuarick, with his horse, plunges before he is aware, and is received at the bottom upon sharp-pointed stakes, which often kill the one and the other on the spot. Unluckily, harmless travellers are equally liable to fall into these living graves. Major Denham was petrified with horror to find how near he had approached to several of them; indeed, one of his servants fell in, and was saved only by an almost miraculous spring. It seems wonderful that the sheik should not have endeavoured to restore some kind of security to this portion of his subjects, and to repeople those fine but deserted regions.

The troops, which had been seen hastening in parties to the scene of action, were mustered at Kabshary, a town which the Mungas had nearly destroyed. The sheik made a review of his favourite forces, the Kanemboo spearmen, 9000 strong. They were really a very savage and militarylooking host, perfectly naked, except a girdle of goatskin, with the hair hanging down, and a piece of cloth wrapped round the head. They carried large wooden shields, shaped like a Gothic window, with which they warded off the arrows of the enemy, while they pressed forward to attack with their spears. Unlike almost all other barbarous armies, they kept a regular night-watch, passing the cry every halfhour along the line, and at any alarm raising a united yell, which was truly frightful. At the review they passed in tribes before the sheik, to whom they showed the most enthusiastic attachment, kneeling on the ground and kissing his feet. The Mungas, again, were described as terrible 



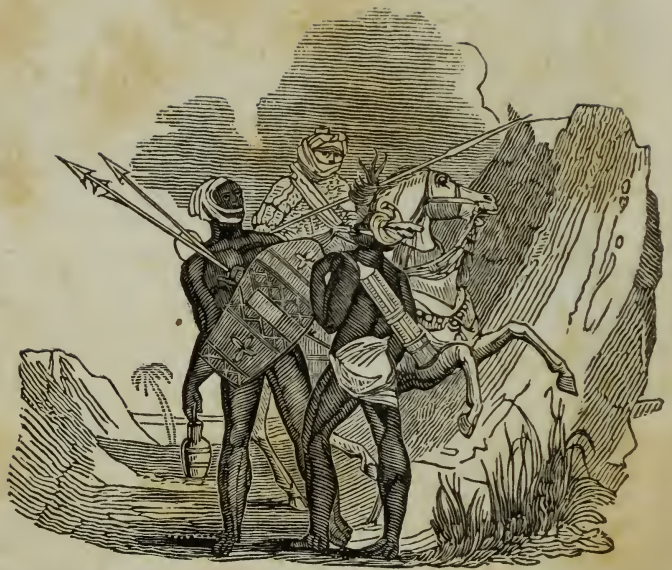

Bornou Horseman, Kanemboo Spearman, and Mungo Bowman. - [p.157.] 
antagonists, hardened by conflict with the Tuaricks, fighting on foot with poisoned arrows longer and more deadly than those of the Fellatas.* The sultan, however, contemplated other means of securing success, placing his main reliance on his powers as a Mohammedan doctor and writer. Three successive nights were spent in inscribing upon little scraps of paper figures or words, destined to exercise a magical influence upon the rebel host; and their effect was heightened by the display of sky-rockets, supplied by Major Denham. Tidings of his being thus employed were conveyed to the camp, when the Mungas, stout and fierce warriors who never shrunk from an enemy, yielded to the power of superstition, and felt all their strength withered. It seemed to them that their arrows were blunted, their quivers broken, their hearts struck with sickness and fear; in short, that to oppose a sheik of the Koran who could accomplish such wonders was alike vain and impious. They came in by hundreds, bowing themselves to the ground, and casting sand on their heads in token of the most abject submission. At length, Malem Fanamy himself, the leader of the rebellion, saw that resistance was hopeless. After vain overtures of conditional submission, he appeared in person, mounted on a white horse, with a thousand followers. He was himself in rags, and, having fallen prostrate on the ground, was about to pour sand on his head, when the sultan, instead of permitting this humiliation, caused eight robes of fine cotton cloth, one after another, to be thrown over him, and his head to be wrapped in Egyptian turbans till it was swelled to six times its natural size, and no longer resembled any thing human. By such signal honours the sheik gained the hearts of those whom his pen had subdued; and this wise policy enabled him, not only to overcome the resistance of this formidable tribe, but to convert them into supporters and bulwarks of his power.

Major Denham, who always sought with laudable zeal to penetrate into every corner of Africa, now found his way in another direction. He had heard much of the Shary, a great river flowing into the lake Tchad, and on whose banks the kingdom of Loggun was situated. After several delays,

* The group in the accompanying plate shows the three noted military charseters, - the Bornou horseman, the Kanemboo spearman, and the Munga bowman. 
he set out on the 23d January, 1824, in company with Mr. Toole, a spirited young volunteer, who, journeying by way of Tripoli and Mourzouk, had thence crossed the Desert to join him. The travellers passed through Angornou and Angala, and arrived at Showy, where they saw the river, which really proved to be a magnificent stream, fully half a mile broad, and flowing at the rate of two or three miles an hour. They descended it through a succession of noble reaches, bordered with fine woods, and a profusion of variously-tinted and aromatic plants. At length it opened into the wide expanse of the Tchad; after viewing which, they again ascended and reached the capital of Loggun, beneath whose high walls the river was seen flowing in majestic beauty. Major Denham entered, and found a handsome city, with a street as wide as Pall-Mall, and bordered by large dwellings, having spacious areas in front. $\mathrm{He}$ was led through several dark rooms into a wide and crowded court, at one end of which a lattice opened, and showed a pile of silk robes stretched on a carpet, amid which two eyes became gradually visible: this was the sultan. On his appearance there arose a tumult of homs and frumfrums; while all the attendants threw themselves prostrate, casting sand on their heads. In a voice which the courtfashion of Loggun required to be scarcely audible, the monarch inquired Major Denham's object in coming to this country, observing that if it was to purchase handsome female slaves, he need go no farther, since he himself had hundreds who could be afforded at a very easy rate. This overture was rejected on other grounds than the price; yet, notwithstanding so decided a proof of barbarism, the Loggunese were found a people more advanced in the arts of peace than any hitherto seen in Africa. By a studied neutrality, they had avoided involving themselves in the dreadful wars which had desolated the neighbouring countries. Manufacturing industry was honoured, and the cloths woven here were superior to those of Bornou, being finely died with indigo and beautifully glazed. There was even a current coin made of iron, somewhat in the form of a horse-shoe; and rude as this was, none of their neighbours possessed any thing similar. The ladies were handsome, intelligent, and of a lively air and carriage; but, besides pushing their frankness to excess, their general demeanour 
was by no means scrupulous. They used, in particular, the utmost diligence in stealing from Major Denham's person every thing that could be reached, even searching the pockets of his trousers ; and, when detected, only laughing, and calling to each other how sharp he had shown himself. But the darkest feature of savage life was disclosed, when the sultan and his son each sent to solicit poison "that would not lie," to be used against the other. The latter even accompanied the request with a bribe of three lovely black damsels, and laughed at the horror which was expressed at the proposal.

The Loggunese live in a rich country, abounding in grain and cattle, and diversified with forests of lofty acacias and many beautiful shrubs. Its chief scourge consists in the millions of tormenting insects which fill the atmosphere, making it scarcely possible to go into the open air at midday without being thrown into a fever; indeed, children have been known to be killed by their stings. The natives have a mode of building one house within another to protect themselves against this scourge; while some kindle a large fire of wet straw and sit in the smoke : but this remedy, if it be possible, seems worse than the evil which it is meant to obviate.

Major Denham was much distressed on this journey by the death of his companion Mr. Toole; and he could no longer delay his return when he learned that the Begharmis, with a large army, were crossing the Shary to attack Bornou. Soon after his arrival at Kouka the sheik led out his troops, which he mustered on the plain of Angala, and was there furiously attacked by 5000 Begharmis, led by 200 chiefs. The Begharmi cavalry are individually strong and fierce, and both riders and horses still more thoroughly cased in mail than those of Bornou; but their courage, when brought to the proof, is nearly on a level. The sheik encountered them with his Kanemboo spearmen and a small band of musketeers, when, after a sharp conflict, the whole of this mighty host was thrown into the most disorderly flight; even the Bornou cavalry joined in the pursuit. Seven sons of the sultan and almost all the chiefs fell; two hundred of their favourite wives were taken, many of whom were of exquisite beauty.

Mr. Tyrwhit, a gentleman whom his majesty's govern- 
ment had sent out to strengthen the party, arrived on the 20th May, and on the 22d, delivered to the sheik a number of presents, which were received with the highest satisfaction. In company with this gentleman, Major Denham, eager to explore Africa still further, took advantage of another expedition undertaken against the tribe of Shouaa Arabs, distinguished by the name of $\mathrm{La}$ Sala, - a race of amphibious shepherds who inhabit certain islands that extend along the south-eastern shores of the Tchad. These spots afford rich pasture; while the water is so shallow, that, by knowing the channels, the natives can ride without difficulty from one island to the other. Barca Gana led a thousand men on this expedition, and was joined by 400 of a Shouaa tribe, called Dugganahs, enemies to the La Salas. These allies presented human nature under a more pleasing aspect than it had yet been seen in any part of Central Africa. They despise the negro nations, and all who live in houses, and still more in cities; while they themselves reside in tents made of skin, collected into circular camps, which they move periodically from place to place. They live in simple plenty on the produce of their flocks and herds, celebrate their joys and sorrows in extemporary poetry, and seem to be united by the strongest ties of domestic affection. Tahr, their chief, having closely examined our traveller as to the motives of his journey, said, "And have you been three years from your home? Are not your eyes dimmed with straining to the north, where all your thoughts must ever be? If my eyes do not see the wife and children of my heart for ten days, they are flowing with tears when they should be closed in sleep." On taking leave, Tahr's parting wish was, "May you die at your own tents, and in the arms of your wife and family." This chief, it is said, might have sat for the picture of a patriarch : his fine, serious, expressive countenance, large features, and long bushy beard afforded a favourable specimen of the general aspect of his tribe.

The united forces now marched to the shores of the lake, and began to reconnoitre the islands on which the Shouaas with their cattle and cavalry were stationed; but the experienced eye of Barca Gana soon discerned that the channel, though shallow, was full of holes, and had a muddy, deceitful appearance. He proposed, therefore, to 
delay the attack till a resolute band of Kanemboo spearmen should arrive and lead the way. The lowing, however, of the numerous herds, and the bleating of the flocks on the green islands which lay before them, excited in the troops a degree of hunger as well as of military ardour that was quite irrepressible. They called out, "What! be so near them and not eat them? No, no, let us on; this night these flocks and women shall be ours!" Barca Gana suffered himself to be hurried away, and plunged in among the foremost. Soon, however, the troops began to sink into the holes or stick in the mud; their guns and powder were wetted, and became useless; while the eneiny, who knew every step, and could ride through the water as quickly as on land, at once charged the invaders in front, and sent round a detachment to take them in the rear. The assault was accordingly soon changed into a disgraceful flight, in which those who had been the most loud in urging to this rash onset set the example. Barca Gana, who had boasted himself invulnerable, was deeply wounded through his coatof-mail and four cotton tobes, and was with difficulty rescued by his chiefs out of the hands of five La Sala horsemen who had vowed his death. The army returned to their quarters in disappointment and dismay, and with a severe loss. During the whole night the Dugganah women were heard bewailing their husbands who had fallen, in dirges composed for the occasion, and with plaintive notes, which could not be listened to without the deepest sympathy. Major Denham was deterred by this disaster from making any farther attempt to penetrate to the eastern shores of the Tchad.

The Biddoomahs are another tribe who inhabit extensive and ragged islands in the interior of the lake, amid its deep waters, which they navigate with nearly a thousand large boats. They neither cultivate the ground nor rear flocks or herds, while their manners appeared to our traveller the rudest and most savage even of Africans, those of the Musgow always excepted. They are said to have adopted as a religious creed, that God, having withheld from them corn and cattle, which the nations around enjoy, has given in their stead strength and courage, to be employed in taking these good things from all in whose possession they may be found. To this belief they act up in the most devout $\mathrm{O} 2$ 
manner, spreading terror and desolation over all the shores of this inland sea; no part of which, even in the immediate vicinity of the great capitals, is ' for a moment secure from their ravages. The most powerful and warlike of the Bornou sovereigns, finding among their subjects neither the requisite skill nor experience in navigation, do not attempt to cope with the Biddoomahs on their watery domains; and thus gave up the lake to their undisputed sway.

While Major Denham was thus traversing, in every direction, Bornou and the surrounding countries, Mr. Clapperton and Dr. Oudney were proceeding through Houssa, by a route less varied and hazardous indeed, but disclosing forms both of nature and of society fully as interesting. They departed from Kouka on the 14th December, 1823, and, after passing the site of Old Birnie, they found the banks of the Yeou fertile, and diversified with towns and villages. On entering Katagum, the most easterly Fellata province, they observed a superior style of culture; two crops of wheat being raised in one season by irrigation, and the grain stored in covered sheds elevated from the ground on posts. The country to the south was covered with extensive swamps and mountains, tenanted by rude and Pagan races, who furnish to the faithful an inexhaustible supply of slaves. The practice of travelling with a caravan was found very advantageous, from the mutual help afforded, as well as from the good reports spread by the merchants respecting their European companions. In Bornou these last had been viewed with almost unmingled horror; and, for having eaten their bread under the extremest necessity, a man had his testimony rejected in a court of justice. Some young Bornouese ladies, who accosted Major Denham, having ventured to say a word in his favour, an attendant matron exclaimed,- "Be silent; he is an uncircumcised Caffre,-neither washes nor prays, eats pork, and will go to hell ;" upon which the others screamed out and ran off. But in Houssa this horror was not so extreme, and was mingled with the belief that they possessed surprising and supernatural powers. Not only did the sick come in crowds expecting the cure of every disease, but the ladies solicited amulets to restore their beauty, to preserve the affections of their lovers, and even to destroy a hated rival. The son 
of the governor of Kano, having called upon Mr. Clapperton, stated it as the conviction of the whole city and his own, that the English had the power of converting men into asses, goats, and monkeys, and likewise that by reading in his book he could at any time commute a handful of earth into gold. The traveller, having argued with him upon the difficulty he often found in procuring both asses and gold, induced him, with trembling hands, to taste a cup of tea; when he became more composed, and made a sort of recantation of his errors.

As the caravalı proceeded they met many other travellers, and found sitting along the road numerous females, selling potatoes, beans, bits of roasted meat, and water with an infusion of gussub grains; and when they stopped at any place for the night, the people crowded in such numbers as to form a little fair. Mr. Clapperton attracted the notice of many of the Fellata ladies, who, after examining him closely, declared, that had he only been less white, his external appearance might have merited approbation.

The travellers passed through Sansan, a great marketplace divided into three distinct towns, and Katagum, the strongly-fortified capital of the province, containing about 8000 inhabitants. Thence they proceeded to Murmur, where the severe illness under which Dr. Oudney had long laboured came to a crisis. Though now in the last stage of consumption, he insisted on continuing his journey, and with the aid of his servant had been supported to his camel, when Mr. Clapperton, seeing the ghastliness of death on his countenance, insisted on replacing him in his tent; where soon after, without a groan, he breathed his last. His companion caused him to be buried with the honours of the country. The body was washed, wrapped in turban-shawls, and a wall of clay built round the grave to protect it from wild beasts; two sheep also were killed and distributed among the poor.

Proceeding onwards, the traveller came to Katungwa, the first town of Houssa Proper, in a country well enclosed and under high cultivation. To the south was an extensive range of rocky hills, amid which was the town of Zangeia, with its buildings picturesquely scattered over masses of rock. He passed also Girkwa, near a river of the same name, which appears to come from these hills, and to fall into the Yeou. 
Two days after, he entered Kano, the Ghana of Edrisi, and which is now, as it was six hundred years ago, the chief commercial city of Houssa and of all Central Africa. Yet it disappointed our traveller on his first entry, and for a quarter of a mile scarcely appeared a city at all. Even in its more crowded quarters the houses rose generally in clusters, only separated by large stagnant pools. The inhabited part, on the whole, did not appear to comprise more than a fourth of the space enclosed by the walls, while the rest consisted of fields, gardens, and swamps ; however, as the whole circuit is fifteen miles, there is space for a population moderately estimated to be between 30,000 and 40,000 . Its market, the greatest scene of commercial transactions in Africa, is held on a neck of land between two swamps, by which, during the rains, it is entirely overflowed; but in the dry season it is covered with sheds, or stalls of bamboo, arranged into regular streets. Different quarters are allotted for the several kinds of goods; some for cattle, others for vegetables; while fruits of various descriptions, so much neglected in Bornou, are here displayed in profusion. The fine cotton fabrics of the country are sold either in webs, or in what are called tobes and turkadees, with rich silken stripes or borders ready to be added. Among the favourite articles are goora or kolla nuts, which are called African coffee, being supposed to give a peculiar relish to the water drunk after them; and crude antimony, with whose black tint every eyebrow in Houssa must be died. The Arabs also dispose here of sundry commodities that have become obsolete in the north; the cast-off dresses of the Mamelukes and other great men, and old swordblades from Malta. But the busiest scene is the slavemarket, composed of two long ranges of sheds, one for males and another for females. These poor creatures are seated in rows, decked out for exhibition; the buyer scrutinizes them as nicely as a purchaser with us does a horse, inspecting the tongue, teeth, eyes, and limbs, making them cough and perform various movements, to ascertain if there be any thing unsound; and in case of a blemish appearing, or even without assigning a reason, he may return them within three days. As soon as the slaves are sold, the exposer gets back their finery, to be employed in ornamenting others. Most of the captives purchased at Kano are conveyed across the Desert, during which their masters endea- 
vour to keep up their spirits by an assurance that, on passing its boundary, they will be set free and dressed in red, which they account the gayest of colours. Supplies, however, often fail in this dreary journey,-a want felt first by the slaves, many of whom perish with hunger and fatigue. Mr. Clapperton heard the doleful tale of a mother who had seen her child dashed to the ground, while she herself was compelled by the lash to drag on an exhausted frame. Yet when at all tolerably treated, they are very gay,-an observation generally made in regard to slaves; but this gayety, arising only from the absence of thought, probably conceals much secret wretchedness.

The regulations of the market of Kano seem to be good, and strictly observed. There is a sheik who regulates the police, and is said even to fix the prices,-which is going too far. The dylalas, or brokers, are men of somewhat high character; packages of goods are often sold unopened, and bearing merely their mark. If the purchaser afterward finds any defect, he returns it to the agent, who must grant compensation. The medium of exchange is not cloth as in Bornou, nor iron as in Loggun, but cowries, or little shells brought from the coast, twenty of which are worth a halfpenny, and 480 make a shilling; so that, in paying a pound sterling, one has to count over 9600 cowries. Our countryman admires this currency, as excluding all attempts at forgery; but really we should think its use very tedious and inconvenient. Amid so many strangers there is ample room for the trade of the restaurateur, which is occupied by a female seated on the ground, with a mat on her knees, on which are spread vegetables, gussub-water, and bits of roasted meat about the size of a penny; these she retails to her customers squatted around her. The killing of a bullock forms a sort of festival at Kano; its horns are died red with henna, drums are beat, and a crowd collected, who, if they approve of the appearance and condition of the animal, readily become purchasers.

Boxing in Houssa, like wrestling in Bornou, forms a favourite exercise, and the grand national spectacle." $\mathrm{Mr}$. Clapperton, having heard much of the fancy of Kano, intimated his willingness to pay for a performance, which was forthwith arranged. The whole body of butchers attended, and acted as masters of the ceremonies; while, as soon as 
the tidings spread, girls left their pitchers at the wells, the market people threw down their baskets, and an immense crowd was assembled. The ring being formed, and drums beat, the performers first came forward singly, plying their muscles like a musician tuning his instrument, and each calling out to the bystanders, - "I am a hyena; I am a lion; I can kill all that oppose me." After about twenty had shown off in this manner, they came forward in pairs, wearing only a leathern girdle, and with their hands muffled up in numerous folds of country cloth. It was first ascertained that they were not mutual friends ; after which, they closed with the utmost fury, aiming their blows at the most mortal parts, as the pit of the stomach, beneath the ribs, or under the ear: they even endeavoured to scoop out the eyes ; so that, in spite of every precaution, the match often terminated in the death of one of the combatants. Whenever Mr. Clapperton saw the affair verging to such an issue, he gave orders to stop; and, after seeing six pairs exhibit, paid the hire and broke up the meeting.

From Kano he set out under the guidance of Mohammed Jollie, leader of an extensive caravan intended for Sackatoo, capital of the sultan of the Fellatas. The country was perhaps the finest in Africa, being under high cultivation, diversified with groves of noble trees, and traversed in a picturesque manner by ridges of granite. The manners of the people, too, were pleasing and pastoral. At many clear springs gushing from the rocks young women were drawing water. As an excuse for engaging in talk, our traveller asked several times for the means of quenching his thirst. "Bending gracefully on one knee, and displaying at the same time teeth of pearly whiteness, and eyes of the blackest lustre, they presented a gourd, and appeared highly delighted when I thanked them for their civility, remarking to one another, "Did you hear the white man thank me?" But the scene was changed when the traveller reached the borders of the provinces of Goober and Zamfra, which were in a state of rebellion against Sackatoo. The utmost alarm at that moment prevailed; men and women, with their bullocks, asses, and camels, all struggled to be foremost, every one crying out, "Wo to the wretch that falls behind! he will be sure to meet an unhappy end at the hands of the Gooberites." There was danger even of being 
thrown down and trampled to death by the bullocks, which were furiously rushing backward and forward; however, through the unremitting care of the escort, Clapperton made his way safely, though not without much fatigue and annoyance, along this perilous frontier.

On the 16th March, 1824, after passing through the hilly district of Kamoon, the valleys began to open, and crowds of people were seen thronging to market with wood, onions, indigo, and other commodities. This indicated the approach to Sackatoo, which they soon saw from the top of a hill, and entered about noon. A multitude flocked to see the white stranger, and received him with cheers of welcome. The sultan was not yet returned from a ghrazzie or slave-hunt; but the gadado, or minister, performed handsomely the honours of the place. Next day the chief arrived, and instantly sent for Clapperton. The palace, as usual in Africa, consisted of a sort of enclosed town, with an open quadrangle in front. The stranger, on entering the gate, was conducted through three huts serving as guard-houses, after which he found Sultan Bello seated on a small carpet in a sort of painted and ornamented cottage. Bello had a noble and commanding figure, with a high forehead and large black eyes. He gave the traveller a hearty welcome, and, after inquiring the particulars of his journey, proceeded to serious affairs. He produced books belonging to Major Denham, which had been taken in the disastrous battle of Dirkullah; and, though he expressed a feeling of dissatisfaction at the Major's presence on that occasion, readily accepted an apology, and restored the volumes. He only asked to have the subject of each explained, and to hear the sound of the language, which he declared to be beautiful. He then began to press his visiter with theological questions, and showed himself not wholly unacquainted with the controversies which have agitated the Christian world ; indeed he soon went beyond the depth of his visiter, who was obliged to own that he was not versant in the abstruser mysteries of divinity.

The sultan now opened a frequent and familiar communication with the English envoy, in which he showed himself possessed of a good deal of information. The astronomical instruments, from which, as from implements of magic, 
many of his attendants started with horror, were examined by the monarch with an intelligent eye. On being shown the planisphere, he proved his knowledge of the planets, and even of many of the constellations, by repeating their Arabic names. The telescope, which presented objects inverted -the compass, by which he could always turn to the east in praying - and the sextant, which he called " the lookingglass of the sun," excited peculiar interest. Being desirous to see an observation performed with the latter instrument, Clapperton, who had lost the key of the artificial horizon, asked a dagger to break it open; upon which the sultan started, and half-drew his sword, trembling like an aspen leaf. The other very prudently took no notice of this excitement, but quietly opened his box, when the exhibition soon dispelled all unfavourable impressions. The sultan, however, inquired with evident jealousy into some points of English history that had come to his knowledge; as, the conquest of India, which the traveller endeavoured to represent as a mere arrangement to protect the natives, and particularly the Moslem population. The attack on Algiers, being also alluded to, was justly declared to have been made solely on account of her atrocious piracies.

Sackatoo appeared to Mr. Clapperton the most populous city he had seen in the interior of Africa. The houses stand more closely together than in most other towns of Houssa, and are laid out in regularly well-built streets. It is surrounded by a wall between twenty and thirty feet high, with twelve gates, which are punctually shut at sunset. The dwellings of the principal inhabitants consist of clusters of cottages and flat-roofed houses, in the Moorish style, enclosed by high walls. There are two mosques, one of which, then in progress of building, was 800 feet long, adorned with numerous pillars of wood plastered with clay, and highly ornamented.

Mr. Clapperton, desirous to accomplish what had all along been his main object, solicited a guide to the western countries and the Gulf of Benin. By this route he might investigate the course of the Niger and the fate of Park; he might also pave the way for a commercial intercourse, which would be of some benefit to Britain, and of great advantage to Africa. The sultan at first gave assurances of permission and aid in travelling through every part of his domi- 
nions; but when our countryman specified Nyffe on the banks of the Niger, Youri where the papers of Park were reported to be kept, Rakah and Fundah, where that river was said to fall into the sea, the courtiers began to demur. Professing tender solicitude for his safety, they represented that the season was becoming unfavourable, and that rebellion and civil war were raging to such a pitch in these countries as to make even the mighty protection of Sultan Bello insufficient for his security. Clapperton strongly suspected that this unfavourable change was produced by the machinations of the Arabs, and particularly of Mohammed Gomsoo, their chief, notwithstanding the warm professions of friendship made that personage. They apprehended, probably, that were a communication opened with the western coast, Interior Africa might be supplied with European goods by that shorter route, instead of being brought by themselves across the Desert. Perhaps these suspicions were groundless; for the state of the country was afterward found to be, if possible, worse than had been described, and the ravages of the Fellatas so terrible, that any one coming from among them was likely to experience a very disagreeable reception. Indeed, it may be suspected that the sultan must have been a good deal embarrassed by the simplicity with which his guest listened to his pompous boasting as to the extent of his empire, and by the earnestness with which he entreated him to name one of his seaports where the English might land, when it is certain that he had not a town which was not some hundred miles distant from the coast. To prevent the disclosure of this fact, which must have taken place had our traveller proceeded in that direction, might be an additional motive for refusing his sanction. In short, it was finally announced to Clapperton, that no escort could be found to accompany him on so rash an enterprise, and that he could return to England only by retracing his steps.

Here the traveller obtained an account of Mr. Park's death, very closely corresponding with the statement given by Amadi Fatouma. The Niger, it appears, called here the Quorra, after passing Timbuctoo, turns to the south, and continues to flow in that direction till it crosses the parallel of Sackatoo, at only a few days' journey to the westward ; but whether it reaches the sea, or, making an immense cir- 
cuit, becomes the Shary, and pours itself into the immense basin of the Tchad, are points on which his informants varied greatly.

Returning by a different route, Mr. Clapperton visited Zirmie, the capital of Zamfra, a kind of outlawed city, the inhabitants of which are esteemed the greatest rogues in Houssa, and where all runaway slaves find protection. He passed also through Kashna or Cassina, the metropolis of a kingdom which, till the late rise of the Fellata power, hail ruled over all Africa from Bornou to the Niger. In its present subject and fallen state, the inhabited part does not cover a tenth of the wide circuit enclosed by its walls; yet a considerable trade is still carried on with the Tuaricks, or with caravans coming across the Desert by the route of Ghadamis and Tuat. Here our traveller met with much kindness from Hadgi Ahmet, a powerful and wealthy Arab chief, who even took him into his seraglio, and desired him, out of fifty black damsels, to make his choice, - a complaisance, nothing resembling which had ever before been shown by a Mussulman. But our countryman, being indisposed, only picked out an ancient maiden to serve as a nurse.

Mr. Clapperton rejoined Major Denham at Kouka, whence they set out, and recrossed the Desert together in the latter part of the year 1824. They reached Tripoli in January, 1825, and soon after embarked for Leghorn; but being detained by contrary winds and quarantine regulations, did not reach London till the month of June.

\section{CHAPTER XIII.}

\section{Clapperton's Second Journey-Laing-Caillik.}

I $\mathrm{T}$ has appeared, that in spite of some occasional symptoms of jealousy, and even of alarm, the sultan of the Fellatas had manifested a very considerable inclination to cultivate intercourse with the English. He was even understood to have promised that messengers should be kept in waiting at Rakah and Fundah, or at some port on the coast, 
to conduct a new mission to Sackatoo. These promises, it is extremely probable, were mere inferences drawn from the empty boasts of the sultan; he being master neither of $\mathrm{Ra}$ kah nor Fundah, nor of any place within a great distance of the Gulf of Benin. Be this as it may, there seemed good ground to expect a welcome for the British envoys when they should reach his capital ; and in that direction, it was conjectured, were to be found the termination of the Niger, and also the most direct channel of trade with regions already ascertained to be the finest in Africa.

These were views to which the enterprising statesmen who conducted the naval government at home were never insensible. They equipped afresh Mr. Clapperton, now promoted to the rank of captain, and sent him to the Gulf of Benin ; naming as his associates, Captain Pearce, an excellent draftsman; and Mr. Morrison, a naval surgeon of some experience, whose skill, it was hoped, might be of great avail in preserving the health of the whole expedition.

The mission, in the end of 1825, reached its destination; but, as might perhaps have been anticipated, they could hear nothing of Rakah or of Fundah, of any messengers sent by Bello, nor of any town that was subject to him on this coast. They were not, however, discouraged; and having consulted Mr. Houtson, whom a long residence had made thoroughly acquainted with the country, they were advised not to attempt ascending the banks of the river, - - a circuitous track, and covered with pestilential swamps, - but to take the route from Badagry as the most direct and commodious, and by which, in fact, almost all the caravans from Houssa come down to the coast.

On the 7th December, 1825, the mission set out from Badagry on this grand journey into Interior Africa. But at the very first they were guilty of a fatal imprudence. During the nights of the 7 th and 9 th they slept in the open air, and on the last occasion in the public market-place of Dagmoo, without even their beds, which had been sent away by mistake. The consequence was, that in a day or two Morrison and Pearce were attacked with a dangerous fever, and Clapperton with fits of ague. It does not appear why they did not stop in one of the towns, and endeavour by rest to recruit their strength; on the contrary, they pushed on till the 22d, when Captain Clapperton, sceing the illness of his 
companions increase, urged them either to remain behind or return to Badagry. They insisted on proceeding; but next day Dr. Morrison could struggle no longer, and departed for the coast : he died before reaching it. Captain Pearce persevered to the last, and sunk on the road, breathing his last at nine in the evening of the 27th. Clapperton was thus left to pursue his long and adventurous journey in very painful- and desolate circumstances. He had only a faithful servant, Richard Lander, who stood by him in all his fortunes, with Pascoe, a not very trusty African, whom he had hired at Badagry.

After a journey of sixty miles, the travellers entered the kingdom of Yarriba, called also from its capital Eyeo. This country had long been reported on the coast as the most populous, powerful, and flourishing of all Western Africa, holding 'even Dahomey in vassalage. It answered the most favourable descriptions given of it; the fields were extensively cleared, and covered with thriving plantations of Indian corn, millet, yams, and cotton. A loom nearly similar to that used in England was busily plied; the women were spinning and dyeing the cloths with their fine indigo. These African dames were also seen going from town to town bearing large burdens on their heads, - an employment shared by the numerous wives of the king of Eyeo; their majesties having nothing to distinguish them from the humblest of their fellow-countrywomen. Amid these laudable occupations, they exercised their powers of speech with such incessant perseverance as to confirm the Captain in what appears to have been with him an old maxim, that no power on earth, not even African despotism, can silence a woman's tongue; yet, as this loquacity seems to have been always exerted in kindness, he need not, we think, have groaned quite so heavily under its stunning influence.

The English travellers were agreeably surprised by the reception which they experienced during this journey. In Houssa they had laboured under the most dire proscription as Caffres, enemies of the prophet, and foredoomed to hell; and, as black is there the standard of beauty, their colour was considered by the ladies a deep leprous deformity, detracting from every quality that might otherwise have been agreeable in their persons. With the negro and pagan Eyeos there was no religious enmity; and having under- 
stood, by reports from the coast, the superiority of Europeans in arts and wealth, this people viewed them almost as beings of a superior order, to see whom they felt an eager and friendly curiosity. A rumour had also spread that they came to do goỏd, and to make peace wherever there was war. On entering any town they were soon encircled by thousands, all desirous to see white men, and testifying respect, - the males by taking off their caps, the women by bending on their knees and one elbow. In some places singing and dancing were kept up through the whole night in celebration of their arrival.

The mission had now to cross a range of hills about eighty miles broad, reported to reach the whole way from behind Ashantee to Benin. The highest pinnacle was not supposed to exceed 2500 feet, which is a good deal lower than Skiddaw ; but its passes were peculiarly narrow and rugged, hemmed in by gigantic blocks of granite 600 or 700 feet high, sometimes fearfully overhanging the road. The valley varied in breadth from 100 yards to half a mile; but every level spot, extending along the foot of these mountains, or even suspended amid their cliffs, was covered with fine crops of yams, millet, and cotton. A large population thus filled these alpine recesses, all animated with the most friendly spirit. Parties met the travellers on the road, or were stationed on the rocks and heights above, which echoed with choral songs and sounds of welcome. After ascending hill over hill they came to Chaki, a large and populous town, situated on the very summit of the ridge. Here the caboceer had a house and a large stock of provisions ready for them : he put many questions, and earnestly pleaded for a stay of two or three days.

After descending to the plain, and passing through a number of other towns, the party came to Tshow, where a caboceer arrived from the king of Yarriba, with a numerous train of attendants both on foot and horseback. This chief, having shaken hands with them, immediately rubbed his whole body, that the blessing of their touch might be spread all over him. His people kept up through the night a constant hubbub, - singing, drumming, dancing, and firing; and, claiming free quarters, they devoured such a quantity of provisions that the party fared worse than in any other place. Next morning they set out with a crowded escort P 2 
of bowmen on foot, and of horsemen ill mounted but active, dressed in the most grotesque manner, and covered with charms. On reaching the brow of a hill, the great capital of Eyeo opened to the view, on the opposite side of a vast plain bordered by a ridge of granite hills, and surrounded. by a brilliant belt of verdure. On reaching the gate they entered the house of a caboceer, till notice was sent to the king, who immediately invited them to his palace. They had five miles to maich through this spacious capital, during which the multitude collected was so immense, and raised such a cloud of dust, that they must have stopped short, had not their escort, by a gentle but steady application of the whip and the cane, opened a way, and finally cleared a space in front of the throne. The king was sitting under a veranda, dressed in two long cotton tobes, and ornamented with three strings of glass beads, and a pasteboard crown covered with blue cotton, which had been procured from the coast. The mission, instead of the usual prostration, merely took off their hats, bowed, and presented their hands, which the king lifted up three times, calling out "Ako! ako!" (How do you do?) His wives behind, drawn up in a dense body, which the travellers vainly attempted to number, raised loud cheers, and smiled in the most gracious manner. After an interview of half an hour, the chief eunuch showed the party to handsome and commodious lodgings, where a good dinner was prepared. In the evening they were surprised by a visit from his majesty in plain patriarchal style, with a long staff in his hand, saying that he could not sleep without again inquiring after them.

Eyeo, or Katunga, capital of the kingdom of Yarriba, is fifteen miles in circumference, and supplied by seven large markets; but there are many open fields and spaces in this wide circuit, and hence the number of inhabitants could not even be conjectured. The population of the country must be very great, the whole being under cultivation, and the towns large and numerous. The government, in theory, is most despotic. The greatest chiefs, when they approach the sovereign, throw themselves prostrate on the ground, lie flat on their faces, and heap sand or dust upon their heads; and the same degrading homage is paid to the nobles by their inferiors. Yet the administration seems mild and paternal ; no instances of wanton cruelty were 
observed; and the flourishing state of the people showed clearly the absence of all severe oppression. The horrid and bloody customs, which produce such dark scenes in Ashantee and Dahomey, were mentioned here with detestation. At the death of the king only, a few of his principal ministers and favourite wives take poison, presented to them in parrots' eggs, that they may accompany and serve him in the invisible world. The first question asked by every caboceer and great man was, How many wives the king of England had? being prepared, it should seem, to measure his greatness by that standard; but when told that he had only one, thèy gave themselves up to a long and ungovernable fit of laughter, followed by expressions of pity and wonder how he could possibly exist in that destitute condition. The king of Yarriba's boast was, that his wives, linked hand in hand, would reachentirely across the kingdom. Queens, however, in Africa are applied to various uses, of which $\mathrm{Eu}$ ropeans have little idea. They were seen forming a large band of body-guards ; and their majesties were observed in every part of the kingdom acting as porters, and bearing on their heads enormous burdens ; so that whether they should be called queens or slaves seems scarcely doubtful.

The Eyeos, like other nations purely negro, are wholly unacquainted with letters or any form of writing; these are known only to the Arabs or Fellatas, who penetrate thither in small numbers; yet they have a great deal of extemporary poetry. Every great man has bands of singers of both sexes, who constantly attend him, and loudly celebrate his achievements in poems of their own composition. The convivial meetings of the people, even their labours and journeys, are cheered by songs composed for the occasion, and sung often with considerable taste. Their houses are mere clay-built cottages, yet studiously adorned with carving; the door-posts and every piece of furniture are covered with well-executed representations of warlike proces sions, and of the movements of huge serpents seizing their prey. They have also public performances, which do not indeed deserve the name of dramatic, as they consist of mere mimicry and buffoonery. The first act of a piece, witnessed by the strangers exhibited men dancing in sacks, who per formed their part to admiration. One of the bags opened, and there came forth the boa constrictor, fourteen feet long 
covered with cotton cloth, imitating the colour and stripes of the original. Though rather full in the body, it presented very nearly the form, and imitated well the actions, of that huge animal. The mouth was opened wide, probably by two hands, to devour a warrior armed with a sword, who had come forth to contend with this formidable creature, and who struck it with repeated blows, till it writhed in agony, and finally expired. Lastly, out of another sack came the white devil, a meager, shivering figure, and so. painted as to represent an European. It took snuff, rubbed its hands, and attempted, in the most awkward manner, to walk on its naked feet. The audience, amid shouts of laughter, called the particular attention of the Captain to this performance; which being really good, he deemed it advisable to join in the mirth.

As soon as our traveller was fixed at Eyeo, he began to negotiate in regard to the means of advancing into Houssa, anxious to pass through that country and reach Bornou before the rains should set in. The king had professed a determination to serve him in every shape; but this proved to be the very thing in which he was least inclined to fulfil his promise. All African princes seek to make a monopoly of the strangers who enter their territory. It was hinted, that one journey was well and fully employed in seeing the kingdom of Yarriba and visiting its great monarch. Captain Clapperton, having pleaded the positive command of his sovereign, was then informed that the direct route through Nyffe was much disturbed by civil war, the inroad of the Fellatas, and the insurrection of a great body of Houssa slaves,-reports suspected at the time to have been got up merely to detain the travellers, but afterward found to be correct. The king absolutely refused permission to proceed to Rakah, though situated on the Niger at the distance of only three days' journey; but he undertook to convey them to Houssa by a safer though somewhat circuitous route, through the kingdom of Borgoo.

After passing through a number of smaller places, the mission arrived at Kiama, capital of a district of the same name, and containing 30,000 inhabitants. Kiama, Wawa, Niki, and Boussa are provinces composing the kingdom of Borgoo, all subject in a certain sense to the sovereign of Boussa; but the different cities plunder and make war on 
each other, without the slightest regard to the supreme authority. The people of Kiama and of Borgoo in general have the reputation of being the greatest thieves and robbers in all Africa, - character which nothing in their actual conduct appeared to confirm. Clapperton was well received at Kiama; and the king soon visited him with the most singular train ever seen by an European. Six young girls, without any apparel except a fillet on the forehead, and a string of beads round the waist, carrying each three light spears, ran by the side of his horse, keeping pace with it at full gallop. "Their light form, the vivacity of their eyes, and the ease with which they appeared to fly over the ground, made them appear something more than mortal." On the king's entrance the young ladies laid down their spears, wrapped themselves in blue mantles, and attended on his majesty. On his taking leave, they discarded their attire; he mounted his horse, "and away went the most extraordinary cavalcade I ever saw in my life." Our traveller was visited by the principal queen, who had lost her youth and charms ; but a good deal of flirtation passed between him and the eldest daughter, who, however, being twenty-five, was considered in Africa as alcacty on the wane. Yarro, the king, was extremely accommodating, and no difficulty was found in proceeding onward to Wawa.

Wawa is a large city, containing 18,000 inhabitants, enriched by the constant passage of the Houssa caravans. The people spend the wealth thus acquired in dissolute pleasure, and have been denounced by our traveller the most complete set of roaring topers he had ever known. The festivitieg were usually prolonged till near morning, and the town resounded through the whole night with the song, the dance, the castanet, and the Arab guitar. The Wawa ladies paid a very particular and rather troublesome attention to the English party. The Captain complains of being pestered by the governor's daughter, who came several times a-day, always half-tipsy, painted and bedizened in the highest style of African finery, to make love to him ; and on meeting only with cold excuses, she departed usually in a flood of tears. But the most persevering suit was that of Zuma, an A rab widow, possessor of a thousand slaves, and the second personage in Wawa. Being turned of twenty, she was considered here as past her bloom, and a too ample 
indulgence in the luxuries which her wealth afforded had enlarged her dimensions till they could be justly likened to those of a huge water-cask ; yet she had still some beauty, and, being only of a deep-brown complexion, considered herself white, and was in the most eager search after a white husband. In this pursuit she cast her eyes first upon the servant, to whom our traveller hesitates not to assign the palm of good looks in preference to himself; and he gave Lander full permission to follow his fortune. But that sage person, unmoved by all her charms and possessions, repelled the overture in so decided a manner, that the widow soon saw there was nothing to be made of him. She then withdrew her artillery from Lander, and directed it entirely against his master, the Captain, to whom she laid very close siege. At length, in a frolic, he agreed to visit her. $\mathrm{He}$ found her surrounded by every circumstance of African pomp, seated cross-legged on a piece of 'Turkey carpet, with an English pewter mug for her goora-pot, and dressed in a rich striped silk and cotton robe of country manufacture. Her eyebrows were dyed black, her hair blue, her hands and feet red; necklaces and girdles of beads, coral, and gold profusely adorned her person. She made a display of additional finery lodged in her repositories, leading him through a series of apartments, one of which was ornamented with a number of pewter dishes and bright brass pans. After these preliminaries, she at once declared her wish to accompany him on his journey, and proposed to send forthwith for a malem, or holy man, to read the fatha, by which their fates would be indissolubly united. Clapperton, who seems to have been completely stunned by this proposal, stammered out the best apology he could, and hastened away. His conduct, however, does not appear to have been so decisive as to deter the lady from the most energetic perseverance in her suit. She even obtained his permission for his servant Pascoe to accept a wife from among her slaves; but he was not aware that, according to African ideas, she had thus acquired a sort of claim to himself.

Regardless of all these tender solicitations, our traveller had no sooner completed his arrangements than he set out for the Niger, leaving directions for his baggage to join him at the ferry of Comie, while he went round by way of 
Boussa. We shall follow him at present to the former place, where he did not find any of his baggage, but learned that the widow, having placed it under arrest, had left Wawa with drums beating and a numerous train; and besides, that she claimed a full right to his person, because his servant Pascoe had accepted a wife at her hand. It was whispered, moreover, that she was meditating to supplant the governor, - a scheme which, aided by the personal bravery of the strangers, she might probably realize,-and afterward she meant to invite the Captain to ascend the throne of Wąwa. "It would have been a fine end to my journey indeed," says he, "if I had deposed old Mohammed, and set up for myself, with a walking tunbutt for a queen." Scarcely had he received this account when a present from the widow intimated her arrival in a neighbouring village. Our author, however, insensible to all the brilliant hopes thus opened, set off full speed for Wawa to recover his baggage. On his arrival, -the governor refused to liberate it till Zuma's return,-Clapperton in vain protesting that his movements and hers had no sort of connexion. However, next day, the sound of drums was heard, and the widow made her entrée in full pomp, astride on a very fine horse, with housings of scarlet cloth, trimmed with lace. The large circumference of her own person was invested in a red silk mantle, red trowsers, and morocco boots; and numerous spells, sewed variously in coloured leather, were hung all round her. She was followed by a train of armed attendants, and precededyby a drummer decked in ostrich feathers. On the whole, the cene was so splendid, that our hero's resolution seems for a moment to have wavered. However, his part was soon taken. Pascoe was directed to return his wife, and thus extinguish all claim that could be founded upon her; and having received his baggage, our countryman set forward without even admitting the fond widow to any farther conference.

On his way to Comie, Clapperton had visited Boussa, a place chiefly interesting as the scene where the career of Park terminated in a manner so tragical. Every thing tended to confirm the report of Amadi Fatouma, and to dispel the skepticism with which it had been originally regarded. The king, however, and all the citizens, spoke of the event with deep grief and reluctance, and disavowed all 
personal concern in the transaction. One man gave as the reason of the attack on the discoverers, that the English had been mistaken for the advanced guard of the Fellatas, who were then ravaging Soudan. It was added, that a number of natives died in consequence, as was imagined, of eating the meat found in the boats, which was supposed to be human flesh. That the English have no abode but on the sea, and that they eat the flesh of the negroes whom they purchase, are, it seems, two ideas most widely prevalent over Africa. Even the king of Boussa could scarcely be brought to believe that they had a spot of land to dwell upon. The Captain and his party were received, however, with the same kindness and cordiality which they had experienced ever since they entered the country. Seven boats were here waiting for them, sent by the sultan of Youri, with a letter, in which he earnestly solicited a visit, and promised, on that condition, and on that only, to deliver up the books and papers of Park. It is deeply to be regretted that our traveller could not reconcile it with his plans to go to Youri at this time, proposing to visit it on his return, which, it is well known, never took place.

On crossing the Niger, Captain Clapperton entered $\mathrm{Nyffe}$, a country which had been always reported to him as the finest, most industrious, and most flourishing in Africa; but he found it, as iruleed he had been forewarned by the king of Yarriba, a prey to the most desolating civil war. The succession being disputed between two princes, one of them called in the Fellatas, and, by giving up his country to their ravages, obtained the privilege of reigning over its ruins. Our traveller, in his journey to the sansan or camp, saw only wasted towns, plantations choked with weeds, and a few remnants of a miserable populatione This African camp consisted of a number of huts like bee-hives, arranged in streets, with men weaving, women spinning, markets at every green tree, holy men counting their beads, and dissolute slaves drinking; so that, but for the number of horses and armed men, and the drums beating, it might have been. mistaken for a populous village.

Amid this desolation, two towns, Koolfu and Kufu, being walled and situated on the high road of the Houssa caravans, had protected themselves in some measure from the common calamity, and were still flourishing seats of trade. 
All the merchants halted for some time at Koolfu, and those from Bornou seldom went farther. The market was crowded with the same articles as that of Kano. The Moslem religion was the most prevalent; but it had not yet moulded society into the usual gloomy monotony ; nor had it succeeded in secluding or subjecting the female sex, who, on the contrary, were the most active agents in every mercantile transaction. Our traveller knew twenty-one female brokers living at the same time in one house, who went about continually from market to market. Many had amassed considerable wealth, and were persons of great consequence,-quite in their own right. Elated with this distinction, they claimed considerable latitude as to their deportment, and spent whole nights with the men in singing and drinking, - a species of indulgence very prevalent in all these entrepôts of African trade. The English, however, experienced here none of the bigoted enmity which they had encountered in other Moslem cities. On the contrary, they were the objects of much kindness; the principal people of the place sent presents, and the lower ranks sought to obtain a sight of them by mounting the trees which overlooked their residence. The Koran does not seem to have much embarrassed the Koolfuans. Their only mode of studying it was, to have the characters written with a black substance on a piece of board, then to wash them off, and drink the water; and when asked by our traveller what spiritual benefit could be derived from the mere swallowing of dirty water, they indignantly retorted,"What! do you call the name of God dirty water?" This mode of imbibing sacred truth is indeed extensively pursued throughout the interior of the African continent.

Captain Clapperton passed next through Kotongkora and Guari, two states which, united in a league with Cubbi and Youri, had shaken off the yoke of the Fellatas. Guari, strongly situated among hills, could bring a thousand horse into the field. He then entered Zeg-zeg, a Fellata country, which, especially around Zaria, its capital, seems to be one of the very finest in all Africa. It was beautifully variegated with hill and dale, like the finest parts of England, was covered with plentiful crops and rich pastures, and produced the finest rice grown in any part of that continent. Rows of tall trees, resembling gigantic avenues of poplar, 
extended from hill to hill. Zaria, like many other African cities, might be considered as a district of country surrounded with walls. "When the Captain entered, he saw for some time only fields of grain, with the tops of houses rising behind them; still such was its extent, that its population was said to exceed that of Kano, and to amount to at least 50,000 .

Setting out from Zaria, he soon reached his old quarters at Kano; but he unfortunately found that great city in a state of dreadful agitation. There was war on every side; hostilities had been declared between the king of Bornou and the Fellatas; the provinces of Zamfra and Goobur were in open insurrection; the Tuaricks threatened an inroad; in short, there was not a quarter to which the merchants durst send a caravan. Kano being nearly midway between Bornou and Sackatoo, Clapperton left his baggage there to be conveyed to the former on his return, and set out for the capital of Bello, bearing only the presents destined for that prince. On his way he found numerous bands mustering to form an army destined to attack Coonia, the rebel metropolis of Goobur. The appearance of these troops was very striking as they passed along the borders of some beautiful little lakes formed by the river Zirmie. These waters were bordered by forests of flowering acacias, with dark-green leaves, the shadows of which were reflected on the smooth surface of the lake like sheets of burnished gold and silver. "The smoking fires, the sounding of horns, the beating of their gongs or drums, the braying of their brass and tin trumpets, every where the calls on the names of Mohammed, Abda, Mustapha, with the neighing of horses and the braying of asses, gave animation to the beautiful scenery of the lake, and its sloping green and woody banks."

At length the army mustered to the number of 50,000 or 60,000 , chiefly on foot; a rude feudal host, arranging themselves according to their provinces and chiefs, without any military order. In a short time, they formed a dense circle around the walls of Coonia. Captain Clapperton 'expected to see some brilliant exploit performed by the united force of this great army, commanded by the sultan and Gadado in person. The whole, however, both horse and foot, kept carefully out of the reach of the arrows, which, with a 
sure and steady aim, the enemy directed against them. From time to time indeed a doughty warrior, well covered with armour, rode up, calling, "Shields to the wall! Why don't you come on?" but he instantly and quickly rode back, amid the derisive shouts of his countrymen. The only parties who exposed themselves to real danger were a few chiefs, in quilted armour, ornamented with gaudy robes and ostrich plumes, and of such weight that two men were required to lift them on horseback: several of them were brought down by the fire of one well-directed musket from the walls. Evening closed without any thing being effected by this band of heroes; and in the middle of the night, an alarm being raised of a sally from the garrison, the whole besieging army began a tumultuous flight, tumbling over each other and upsetting every thing in their way, thinking only how they might soonest escape from danger. The retreat was continued through the whole of the following day and night, no halt having taken place till ten of the second morning. Thus closed this memorable campaign.

Clapperton, at the sultan's suggestion, repaired to Sackatoo (which he now calls Soccatoo); the monarch himself remaining behind at Magaria, a neighbouring town, which he was raising into a new capital. The traveller's time was spent between the two places. He found, however, an entire change in the feelings of kindness and cordiality towards himself, which had been so remarkably displayed in the former journey. Jealousies had begun to fester in the breasts of the African princes. They dreaded some ambitious design in those repeated missions sent by England without any conceivable motive; for, that men should undertake such long journeys out of mere curiosity, they could never imagine. The sultan accordingly had received a letter from the court of Bornou, warning him that, by this very mode of sending embassies and presents, which the English were now following towards the states of Central Africa, they had made themselves masters of India, and trampled on all its native princes. The writer, therefore, gave it as his opinion that Clapperton should immediately be put to death. An alarm had, in fact, been spread throughout Sackatoo that the English were coming to invade Houssa. The panic was groundless; no European potentate would at present dream of attempting to conquer 
those vast and almost inaccessible regions of Interior Africa. However, with the imperfect knowledge possessed by these chiefs, and the facts before them relative to India, they had scarcely the means of judging as to the foundation of their apprehensions. The sultan, irritated doubtless at the shameful result of his grand expedition against Coonia, felt also another and more pressing fear. War had just broken out between himself and the king of Bornou; Clapperton was on his way to visit that prince, and had left six muskets at Kano, supposed to be intended as presents to him; and six muskets in Central Africa, where the whole Fellata empire could scarcely muster forty, were almost enough to turn the scale between these two great military powers. Under the impulse of these feelings, Bello proceeded to steps unworthy of a prince and a man of honour. He demanded a sight of the letter which Clapperton was conveying to the king of Bornou; and when this was of course refused, he seized it by violence. Lander was induced by false pretences to bring the baggage from Kano to Sackatoo, when forcible possession was taken of the six muskets. The Captain loudly exclaimed against these proceedings, declaring them to amount to the basest robbery, to a breach of all faith, and to be the worst actions of which any man could be guilty. This was rather strong language to be used to a sovereign, especially to one who could at any moment have cut off his head; and the minister even dropped hints as if matters might come to that issue, though, in point of fact, the government did not proceed to any personal violence. But, from other causes, the career of this spirited and hitherto successful traveller was now drawing to a close.

The strong constitution of Clapperton had till this period enabled him to resist all the baneful influences of an African climate. He had recovered, though perhaps not completely, from the effects of the rash exposure which had proved fatal to his two companions; but he had, when overcome with heat and fatigue, in hunting at Magaria, lain down on a damp spot in the open air, and was soon after seized with dysentery, which continued to assume more alarming symptoms. Indeed, after the seizure of the letter to the sultan of Bornou, he was never seen to smile, and in his sleep was heard addressing loud reproaches to 
the Arabs. Unable to rise from bed, and deserted by all his African friends, who saw him no longer a favourite at court, he was watched with tender care by his faithful servant Richard Lander, who devoted his whole time to attendance on his sick master. At length he called him to his bedside, and said-" Richard, I shall shortly be no more,-I feel myself dying." Almost choked with grief, Lander replied, "God forbid, my dear master,-you will live many years yet." But the other replied, "don't be so much affected, my dear boy, I entreat you ; it is the will of the Almighty, it cannot be helped." He then gave particular directions as to the disposal of his papers, and of all that remained of his property; to which strict attention was promised. "He then," says Lander, " took my hand within his, and looking me full in the face, while a tear stood glistening in his eye, said, in a low but deeply-affecting tone, ' $\mathrm{My}$ dear Richard, if you had not been with me I should have died long ago; I can only thank you with my latest breath for your kindness and attachment to me ; and if I could have lived to return with you, you should have been placed beyond the reach of want ; but God will reward you." He still survived some days, and appeared even to rally a little ; but, one morning, Lander was alarmed by a peculiar rattling sound in his throat, and, hastening to the bedside, found him sitting up, and staring wildly around; he laid his head gently on the dying man's shoulder; some indistinct words quivered on his lips ; he strove, but ineffectually, to give them utterance, and expired without a struggle or a sigh.

Bello seems to have repented in some degree of his harsh conduct, especially after news arrived of a great victory gained by his troops over the sultan of Bornou. He allowed Lander to perform the funeral obsequies with every mark of respect. He also supplied him with the means of returning home, allowing him to choose his road, though advising him to prefer that through the Great Desert; but Lander had already had too many dealings with the Arabs, and therefore preferred his old track through the negro countries.

On his arrival at Kano, Lander formed a spirited and highly-laudable design, which proves him to be possessed of a mind much superior to his station. This was nothing 
less than an attempt to resolve the great question respecting the termination of the Niger; which he hoped to effect by proceeding to Fundah, the place, every one admits, at which the point may most easily be determined,-whether it flows onward to the sea or turns eastward into the interior. Lander, in order to reach that city, proceeded due south, through a country diversified with rising ground, but still presenting the same fertile and luxuriant aspect as that through which he had just passed. He was told, however, that to the south there was a very elevated mountainous region, inhabited by a savage people called Yemyems. These are probably the Lamlam of Edrisi, reported to be devourers of human flesh, and who were said to have lately killed and eaten a whole caravan; since which time no one had been much inclined to go near them. The chief place through which Lander passed was Cuttup, composed of five hundred little villages, clustered together, and forming the market for a very great extent of country. The king's wives were vastly delighted to receive one or two gilt buttons from the traveller's jacket; and, imagin- ing them to be pure gold, fastened them to their ears. From Cuttup he proceeded to Dunrora, where he was informed that about half a day's journey eastward was the large city of Jacoba, near which flowed the Shary, in a continuous course between the Tchad and Fundah; which last place lay now in the direction of due west. Lander here promised himself the satisfaction, in ten or twelve days,' of finally solving the grand African problem, when suddenly four horsemen, with foaming steeds, galloped into the town. Their leader, followed by an immense multitude, rode up, and told the traveller that he must instantly return to the king of Zeg-zeg. Lander endeavoured to argue the point, but could get no answer, except that they must either bring him with them or lose their heads. It behooved him then, of necessity, to repair to Zaria, the capital, where, being introduced to the king, and having delivered his presents, that prince boasted of having done him the greatest possible favour, since the people of Fundah, being now at war with Sultan Bello, would certainly have murdered any one who had come from visiting and carrying gifts to that monarch. From this reasoning, sound or otherwise, Lander had no appeal, and found no 
alternative but to make his way back by his former path. In all the places through which he passed, anxious inquiries were made about " his father," as the people called Clapperton ; and when they heard of his death, they raised loud lamentations. He reached Badagry on the 21 st $\mathrm{No}_{0}$ vember, 1827; but, being detained some time there and at Cape Coast Castle, did not reach England till the 30th April, 1828.

The British government were still indefatigable in their exertions to explore every region of Africa. . At the same time that Clapperton proceeded on his second expedition, Major Laing, who had distinguished himself in the Ashantee war, and in the short excursion already mentioned towards the source of the Niger, undertook to penetrate to Timbuctoo, which, from the first era of modern discovery, has been regarded as the most prominent city of Central Africa. Tripoli was again chosen as the starting point, from which he directed his steps south-west across the Desert by way of Ghadamis. He set out under the protection of sheik Babani, who had resided twenty-two years at Timbuctoo, and proved now to be governor of Ghadamis ; but in the midst of the Desert, sixteen days after leaving Tuat, a band of ferocious Tuaricks surprised the cafila while Major Laing was in bed, and having inflicted twentyfour wounds, eight of them with a sabre, left him for dead. Through the care of his companions, however, he made a surprising recovery, numerous portions of bone having been extracted from his head and temples. After some farther delays he succeeded, on the 18th August, 1826, in reaching Timbuctoo, where he remained for upwards of a month. Several letters were received from him dated at that celebrated city, respecting which he stated, that, except in point of extent, which did not exceed the circuit of four miles, it had completely answered his expectation; that he had found its records copious and interesting; and had collected ample materials for correcting and improving the geography of this part of Africa. But his departure was hastened by the following circumstance: Labo, or Bello, sultan of Masina, having obtained the supremacy over Timbuctoo, sent a letter to Osman, the governor, with instructions that the Christian, who, he understood, was expected there, should be forthwith expelled in such a 
manner as to leave him no hope of ever returning. Laing, thus obliged to accelerate his retreat, made an arrangement with Barbooshi, a Moorish merchant, to accompany and protect him in the route by Sego to the coast, which he had determined to follow. Three days after leaving Timbuctoo, when the caravan was in the heart of the Desert, this wretch, instigated by the basest avarice, murdered, in the night-time, the individual whom he had undertaken to guard, taking possession of all his effects. Yet Major Laing's papers, it appears, were carried to Timbuctoo ; nay, the Quarterly Reriew has produced strong reasons for believing that they were actually conveyed back to Tripoli, and that it was owing to the vilest treachery, in a quarter where it ought least to have been apprehended, that they have not been forwarded to the British government. As, however, the light, which is still mucl wanted, may perhaps be hereafter thrown on this dark transaction, we wish not at present to allude to it in a more pointed manner.

Another journey was now announced, which, in the first instance, strongly excited the public expectation. The French savans proclaimed throughout Europe, that M. Caillié, their countryman, animated by the hope of a prize offered by the Society of Geography, had penetrated across Africa from Sierra Leone to Morocco, having passed through Jenne and Tímbuctoo, those two great seats of commerce which modern travellers had sought so long to reach, and whence none had ever returned. Caillié, rewarded with a pension and the cross of the Legion of Honour, was immediately classed with the first of modern travellers. These somewhat extravagant pretensions, contrasted with the defects of the narrative itself when laid before the public, gave rise in high quarters to a doubt whether there were any reality whatever in this expedition, and whether M. Caillié were not another Damberger. On a careful examination of circumstances we are inclined to believe the accuracy of the narrative. There seems good authority for admitting his departure from Sierra Leone ; for his having announced the intention to undertake this journey; and, lastly, for his arrival at Rabat in Morocco, in the condition of a distressed, way-worn traveller. His statement, too, with all its defects, bears an aspect of simplicity and good faith, and contains various minute details, including undesigned coin- 
cidences with facts ascertained from other quarters. His false reports of celestial phenomena might arise from his ignorance of such subjects ; while his inaccuracies in regard to Major Laing might proceed from the defective hearsay information on which he depended. Perhaps these last form rather a presumption in his favour, since, in composing a forgery, he would probably have brought his statements into a studious agreement with those of the Quarterly Review, well known as the only authentic source in this country.

Though disposed to consider M. Caillié's expedition as genuine and authentic, we regard it nevertheless as having made only a limited addition to our knowledge of Interior Africa. English travellers had already explored the country all around Timbuctoo, had traced the Niger far beyond that city, and had ascertained its position in respect to the surrounding regions. The object now is, to obtain a description of Timbuctoo by an intelligent and learned traveller, which M. Caillié is not. He certainly deserves commendation for his enterprise; but fortune has denied him education, and nature has not bestowed upon him any ample share of reflection or judgment. Nevertheless it was impossible to pass through such extensive and remarkable countries without gleaning some valuable information, of which we shall now endeavour to extract the most. important particulars.

René Caillié was born in 1800 , of poor parents, at Mauzé, in the department of the Deux Sèvres. The reading of voyages and travels, and especially of Robinson Crusoe, inspired him, he tells us, with such an unconquerable thirst for adventure as took away all relish for the sports and occupations of his age ; and, after some opposition from his friends, he was permitted to follow his inclination. Having got a sight of some maps of Africa, the vast spaces left vacant, or marked as unknown, excited in his mind a peculiar interest ; hence, in 1816, he sailed from Rochefort for the Senegal. Some time after his arrival, having learned the departure of Major Gray's expedition for the interior, he resolved to join it, and actually set out on foot for that purpose ; but the fatigue of walking over loose sand under a burning sun overpowered him, and he was happy to obtain a water conveyance to Goree. He even 
left Africa, but returned in the end of 1818. Finding at St. Louis a party setting out with supplies for Major Gray, he joined them, and arrived at Bondou, but only in time to witness and share the failure of that expedition.

M. Caillié's health having suffered severely from the fatigues of this journey, he returned and spent some years in France; but in 1824 he repaired again to the Senegal, and resumed his schemes of discovery. With the aid of M. Roger, the governor, he passed nearly a year among the tribe of Moors called Braknas, and conceived himself to have acquired such a knowledge of the manners and religion of that race as would fit him for travelling in the character of a converted Mohammedan on a pilgrimage to Mecca. Having returned to St. Louis, he solicited from two successive governors the sum of 6000 francs, with which he undertook to reach Timbuctoo; but a deaf ear was turned to his application. He then repaired to Sierra Leone, and made the same request to General Turner and Sir Neil Campbell ; but these officers could not be expected, without authority from home, to bestow such a sum on a foreigner possessing no very striking qualifications. They received him kindly, however, and gave him appointments out of which he saved about $80 l$.; when, stimulated by the prize of 1000 francs offered by the French Society of Geography to any individual who should succeed in reaching Timbuctoo, he formed the spirited resolution to undertake this arduous journey with only the resources which the above slender sum could command.

On the 19th April, 1827, M. Caillié set out from Kakundy with a small caravan of Mandingoes. His route lay through the centre of the kingdom of Foota Jallo, in a line intermediate between its two capitals of Teemboo and Laby. This was a very elevated district, watered by the infant streams of the Senegal and Niger, which descend from a still higher region towards the south. It was a laborious route to travel, being steep, rocky, traversed by numerous ravines and torrents, and often obstructed by dense forests. It presented, however, many highly-picturesque views; while the copious rivulets diffused a rich verdure over extensive tracts, on which the Foulahs fed numerous flocks, which, with a little rice they contrived to raise, sufficed for their subsistence. Fruits of various kinds, yams, and other 
vegetables, are also cultivated with success. Their rude agriculture, however, is conducted chiefly by slaves, who are in general well treated, living in villages by themselves, and having two days in the week allowed to provide for their own subsistence. Caillié, like other writers, describes the Foulahs as a fine and handsome people, attached to a pastoral life, but at the same time very warlike, and excessively bigoted in religion.

In his route through Foota Jallo, the traveller crossed the Bafing, not far from its source, where it was still fordable, though it rolled a rapid and foaming stream about 100 paces broad. It is said, at a little distance above, to form a very striking cataract. About 100 miles farther on, in the territory of Kankan, near the village of Couroussa, he came to the Joliba or Niger, already a very considerable river, eight or ten feet deep, and running at the rate of two miles and a half an hour.

Kankan, where the traveller spent some time, is described as an interesting place, with about 6000 inhabitants, surrounded by a beautiful quickset-hedge, answering the purpose of a wall for defence. The market, held thrice a week, is extremely well supplied, not only with the native commodities of cloth, honey, wax, cotton, provisions, cattle, and gold from the neighbouring district of Bouré, but also with European articles brought up from the coast, among which the chief are, firearms, powder, India calicoes, amber, beads, and coral. The adjoining country is fertile and highly cultivated. The Milo, a tributary to the Niger, runs close by the town. To the north is the province of Bouré, which our author represents as more abundant in gold than any other in this part of Africa. The metallic produce here, as well as in the districts visited by Park, is entirely alluvial, imbedded in a species of earth, from which it is separated by agitation in water.

M. Caillié remained more than a month at Kankan before he could find a caravan to guide him through Ouassoulo, a fine country diversified by numerous little villages surrounded by fields neatly laid out and highly cultivated. The people are industrious, mild, humane, hospitable, and, though pagans, feel no enmity towards their Mohammedan neighbours. The women weave a fine cotton cloth, which is exported to all the surrounding districts ; yet there was 
a want of that cleanliness which, in Kankan, had formed a pleasant feature. Beyond Ouassoulo is the town of Sambatikila, the inhabitants of which live in voluntary poverty, bestowing little trouble on the cultivation of the ground, which they allege distracts them from the study of the Koran, - a statement justly derided as only a specious cloak for their indolence. The traveller came next to Timé, situated in a favourable territory, fertile, and profusely irrigated, yielding abundantly various fruits and vegetables, which are scarce or unknown on the coast. Among these were the shea or butter-tree, and the kolla or goora nuts, which are esteemed a great luxury, and conveyed in large quantities into the interior. The victuals, however, were found insipid, owing to the almost total absence of salt, which can only be procured by the wealthy; nor could our traveller at all relish the plan of seasoning food by a sauce extracted from the flesh of mice.

He was detained at Timé upwards of five months by a severe illness. On the 9th January, 1828, he joined a caravan for Jenne, and proceeded through a district generally well cultivated, and containing a number of considerable villages, till, on the 10th March, he came in view, near the village of Cougalia, of the Niger, which appeared to him only about 500 feet broad, but very deep, flowing gently through a flat and open country. The caravan sailed across it, and, after travelling six miles, and passing, by rather deep fords, two smaller branches, they entered the city of Jenne, one of the most celebrated and important in Central Africa, and which had never before been visited by an European traveller.

Jenne is described by Caillié as situated at the eastern extremity of a branch of the Niger separating below Sego from the main current, with which, after passing the former city, it again unites. This delineation seems doubtful. Such a branch, had it existed, would probably have been observed by Park, who, on the contrary, describes the river which passes by Jenne as a separate stream, tributary to the Niger. The Arabic term, translated by us island, is of very vague import, being familiarly applied to a peninsula, and even to a space wholly or partially enclosed by riverbranches. The country around, as far as the eye could reach, formed only a naked marshy plain, interspersed with 
a few clumps of trees and bushes. The city was two miles and a half in circuit, surrounded by a wall of earth; the houses rather well built, composed of sun-dried bricks, two stories high, without windows in front, but lighted from interior courts. The streets are too narrow for carriages, but of such breadth that seven or eight persons may walk abreast. The population is reckoned by M. Caillie at 8,000 or 10,000 ; but upon this subject we suspect he is apt to form his estimates somewhat too low. The inhabitants consist of various African tribes, attracted by the extensive commerce of which Jenne is the centre. The four principal are the Foulahs, Mandingoes, Bambarras, and Moors, of whom the first are the most numerous, and are bigoted adherents to the Mohammedan faith, compelling the pagan Bambarras who resort to Jenne to conform to the rules of the Koran during their temporary residence. The trade is chiefly in the hands of thirty or forty Moorish merchants, who often unite in partnership, and maintain a communication with Timbuctoo, in barks of considerable size ranged along the river. The negro merchants also carry on business, but on a smaller scale, and chiefly in native articles. The markets are filled with the productions of the surrounding country, either for consumption or exportation, -cloth, grain, fruits, kolla-nuts, meat, fish, gold from Bouré, and unhappily with numerous slaves, who are paraded through the streets, and offered at the rate of from 35,000 to $4.0,000$ cowries each. These commodities draw in return from Timbuctoo, salt, Indian cloths, firearms, beads, toys, and all the variety of European articles. The merchants of Jenne were found more polished in their manners than any native Africans with whom Caillie had yet held intercourse : they were extremely hospitable, entertaining him at free quarters during his whole stay; but he considers them as having driven an exceedingly hard bargain for his goods. The mode of living, even of the most wealthy, was extremely simple. Their houses contained scarcely any furniture; and their clothes were deposited in a large leathern bag, generally suspended from the roof. The chief entertainment to which our traveller was invited consisted merely of a huge fragment of a sheep stewed in onions, and, as usual, eaten with the fingers, - four cups of tea concluding the repast. 
On the 23d March, M. Caillie left Jenne, near which he embarked on the Joliba, which was there half a mile broad, in a vessel of sixty tons burden, but of very slight construction, and bound together with cords. Such barks, impelled without sails, and deeply laden, cannot proceed with safety when the waters are agitated by a brisk gale; therefore much time is consumed in the voyage. The traveller passed first through the country of Banan, which presented a surface flat and monotonous, but abounding in flocks and herds. On the $2 \mathrm{~d}$ April, the river opened into the great lake Dibbie, here called Debo, in sailing across which, notwithstanding its magnitude, land was lost sight of in no direction except the west, where the water appeared to extend indefinitely like an ocean. Three islands, observed at different points, were, not very happily, named St. Charles, Maria Theresa, and Henri, after three individuals who, the author little suspected, would so soon be exiled from France.

After quitting this lake, the Niger flowed through a country thinly occupied by Foulah shepherds, and by some tents of the rude Tuaricks. On the 19th April, he arrived at Cabra, the port of Timbuctoo, consisting of a long row of houses composed of earth and straw, extending about half a mile on the bank of the river. The inhabitants, estimated at about 1200 , are entirely employed in lading and unlading the numerous barks which touch at the quay.

In the evening of the 20th April, Caillie, with some companions, rode from Cabra, and entered Timbuctoo, which he calls Temboctou. He describes himself as struck with an extraordinary and joyful emotion at the view of this mysterious city, so long the object of curiosity to the civilized nations of Europe. The scene, however, presented little of that grandeur and wealth with which the name has been associated. It comprised only a heap of ill-built earthen houses, all around which were spread immense plains of moving sand of a yellowish-white colour, and parched in the extreme. "The horizon is of a pale red,-all is gloomy in nature,the deepest silence reigns, - not the song of a single bird is heard ;" yet there was something imposing in the view of a great city, thus raised amid sands and deserts by the mere power of commerce.

Although M. Caillié resided above a fortnight in Tim 



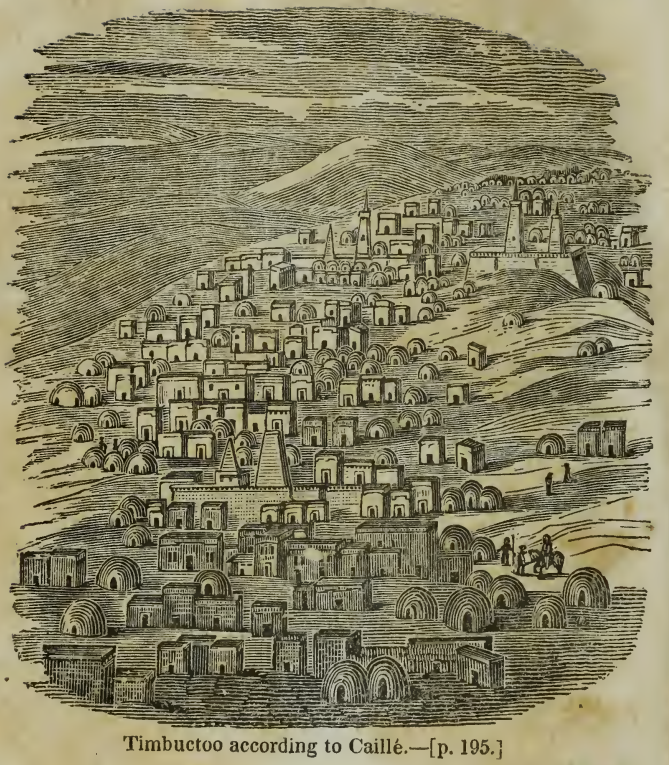


buctoo, his information respecting it is very defective. It appears, except in point of situation, to be nearly such a city as Jenne, consisting of large houses, chiefly tenanted by Moorish merchants, intermingled with conical straw-huts occupied by negroes. The author has given a croquis, or sketch of part of the city, which, though very deficient in perspective, is yet so curious as to merit a place in this publication. There are seven mosques, of which the principal one is very extensire, having three galleries, each two hundred feet long, with a tower upwards of fifty feet high. One part, apparently more ancient than the rest, and almost falling into ruin, was thought to exhibit a style of architecture decidedly superior to the more modern buildings.

Timbuctoo is entirely supported by commerce. It is the depot of the salt conveyed from the mines of Taudeny, and also of the European goods brought by the caravans from Morocco, as well as by those from Tunis and Tripoli, which come by way of Ghadamis. These goods are embarked for Jenne, to be exchanged for the gold, slaves, and provisions with which that city exclusively supplies Timbuctoo, the neighbourhood being almost a complete desert. The population is estimated at 10,000 or 12,000 , which, not being in proportion to a town three miles in circumference, is probably underrated. The people are chiefly negroes of the Kissour tribe, but bigoted Mohammedans. There appeared less bustle and activity than at Jenne,-a circumstance which does not seem very easily accounted for. Osman, the king, was an agreeable-looking negro of fifty-five, to whom the traveller was introduced, without being aware that he was only viceroy, or at least tributary, to the sultan of Masina. The country is much harassed by the wandering tribe of Tauricks, who, like the Bedouins in Arabia, levy a regular tax on the caravans.*

* The map constructed by M. Jomard, upon Caillie's routes, changes greatly the position of Timbuctoo, especially in respect to longitude, which it places four degrees to the west ward of the site assigned by Major Rennel. It seems impossible, however, to admit an alteration to this extent, which would throw Sego so far westward as to render Park's bearings from Jarra to Sego, and from Sego to Bammakoo, completely erroneous. Besides, it appears to us that M. Jomard has forced to the westward all the positions between Jenue and Timbuctoo, in a manner quite unwarranted by M. Caillié's own descriptions. This excess 
Caillie left Timbuctoo on the 4th May, and in six days arrived at Aroan or Arouan, which he found rather a wellbuilt town of 3000 inhabitants, supported solely by the passage of the caravans from Barbary, and from the salt-mines of Taudeny, which usually halt here before and after passing the desert that extends to the northwards. The environs of Aroan are of the most desolate aspect, and all its provisions are drawn from Jenne by way of Timbuctoo. The neighbourhood does not afford an herb or a shrub, and the only fuel consists of the dried dung of camels. The springs of water, which alone render it habitable, are abundant, but of bad quality. The town also carries on a considerable trade in light goods directly with Sansanding and Yamina. Walet was mentioned as a great emporium, situated to the west-south-west, in a position somewhat different from that assigned by Park ; but the data in both cases are very vague, and we do not see the slightest ground for M. Jomard's conjecture that there are two Walets.

Our traveller departed from Aroan on the 19th May, in company with a caravan of 120 camels laden with the productions of Soudan. He had the prospect of crossing a desert of ten days' journey, in which there was scarcely a drop of water. "Before us appeared a horizon without bounds, in which our eyes distinguished only an immense plain of burning sand, enveloped by a sky on fire. At this spectacle the camels raised long cries, and the slaves mournfully lifted their eyes to heaven." M. Caillié, however, departed in high spirits, animated by the idea of being the first European who should, from the southern side, have

becomes manifest in the line from Galia to the mouth of the Debo, $\mathbf{3 5}$ miles of which are stated to run north-east, without a single movement in a contrary direction; yet $M$. Jomard has manœuvred to make the last position the most westerly of the two. If the route from Jenne to Timbuctoo lies as much to the northward as M. Caillie represents, where, indeed, he in some measure agrees with the delineation of D'Anville, it must be somewhat farther west than our maps place it, but not nearly so far as $M$. Jomard fixes it. In regard to the nbservation of latitude attempted by the traveller, M. Jomard's claims are indeed very moderate, since he merely argues, that in the absence of any other, this is not. wholly to be neglected; yet even this seems too much, when he at the same time admits, that all the observations made by him in a similar manner are of no value whatever. Under these circumstances, we conceive that it would be premature to change, in our map, the position of Timbuctoo from that formerly fixed by Major Rennel. 
crossed this ocean of shingle. But his tone of feeling was soon lowered when he came to experience the sufferings arising from the intense heat, the blowing of the sand, and the scanty supply of water, which was allowed to the caravan only twice a-day leaving long intervals, during which the most tormenting thirst was endured. Some small wells, from which they had hoped for a little aid, were found dry; so that both men and animals were reduced to the last extremity, when they reached the copious springs of Telig, and relieved their thirst by repeated draughts.

During many succeeding marches, water again became scarce, and Caillié had much to suffer from the insult and neglect of his companions. El Drah, on the outer frontier of Morocco, was the first inhabited district; but it was poor, and occupied by inhospitable tribes of Moors and Berebbers. Turning somewhat eastward, they passed through the fine country of Tafilet, covered with noble woods of date-trees, and producing a valuable breed of sheep. They then crossed with labour a rugged limb of the Atlas, and arrived at Fez, whence the adventurer found his way, though in a somewhat poor plight, to Tangier. He arrived on the 18th August, 1828, and M. Delaporte, the vice-consul, received and forwarded him to France.

\section{CHAPTER XIV.}

\section{Western Africa.}

ThE whole coast of Western Africa within the tropics, forming a wide sweep around the Gulf of Guinea, has long been occupied by a chain of European forts, erected with a view to the commerce in gold, iron, and palm-oil, but above all in slaves; and since this last object has been finally abandoned by Great Britain, these stations have become to her of very secondary importance. The territory is in the possession of a number of petty states, many of which compose aristocratic republics, turbulent, restless, licentious, and generally rendered more depraved by their fre- 
quent intercourse with Europeans. The interior country, extending parallel to the great central chain of mountains, of which the principal branch is here called Kong, presents nothing of that desert and arid character which is stamped on so great a proportion of the African continent. The soil, copiously watered, is liable rather to an excessive luxuriance; but, where well managed, it is highly fruitful. There are found, too, in this tract, several very powerful kingdoms, better organized and more improved than any near the coast. They have not, however, the slightest tincture of European civilization; and their manners, in several important respects, are stained with habits and practices that belong to the very lowest stage of savage life.

Of these greater states the first to which Europeans penetrated was Dahomey, which had distinguished itself early in the last century by the conquest it then achieved of the flourishing kingdom of Whidah, on the slave-coast. The Dahomans committed the most horrible ravages that were ever witnessed,-reducing their country, the most fertile and beautiful then known in Western Africa, to almost utter desolation. As the king of Dahomey continued to hold sway over this province, Mr. Norris, in 1772, undertook a journey thither to observe the character and position of this extraordinary potentate, and to make arrangements for the benefit of the English trade. He passed through a fine country, abounding in the usual tropical productions, and rising by a gentle ascent about 150 miles inland to Abomey, the capital. $\mathrm{He}$ arrived at an appalling season, that of the annual customs, when the great men were assembled from every quarter of the kingdom; and he was truly astonished to see those fierce and warlike chieftains, whose very name spreads terror throughout Africa, prostrating themselves before the monarch, flat on the ground, and piling dust on their heads in token of the most abject submission. This homage is yielded, not from fear, but from a blind and idolatrous veneration, which makes them regard their king in the light of a superior being. In his name they rush to battle, and encounter their foes with Spartan intrepidity. One of them said to Mr. Norris, "I think of my king, and then I dare engage five of the enemy myself." $\mathrm{He}$ added, "My head belongs to the king, and not to myself; if he please to send for it, I 
am ready to resign it ; or if it be shot through in a battle, I am satisfied, since it is in his service." The main object contemplated in this national anniversary is, that the king may water the graves of his ancestors with the blood of human victims. These are numerous, consisting of prisoners taken in war, of condemned criminals, and of many seized by lawless violence. The captives are brought out in succession, with their arms pinioned; and a fetisheer, laying his hand upon the devoted head, utters a few magic words, while another from behind, with a large scimitar, severs it from the body, when shouts of applause ascend from the surrounding multitude. At any time when the king has a message to convey to one of his deceased relations, he delivers it to one of his subjects, then strikes off his head, that he may carry it to the other world; and if any thing farther occurs to him after he has performed this ceremony, he delivers it to another messenger, whom he despatches in the same manner.

Another grand object of this periodical festival is the market for wives. All the unmarried females throughout the kingdom are esteemed the property of the sovereign, and are brought to the annual customs, to be placed at his disposal. He selects for himself such as appear most beautiful and engaging, and retails the others at enormous prices to his chiefs and nobles. No choice on this occasion is allowed to the purchaser ; in return for his twenty thousand cowries, a wife is handed out, and, even be she old and ugly, he must rest contented; nay, some, it is said, have in mockery been presented with their own mothers. The king usually keeps his wives up to the number of three thousand, who serve him in various capacities,-being partly trained to act as a body-guard, regularly regimented, and equipped with drums, flags, bows and arrows, while a few carry muskets. They all reside in the palace, which consists merely of an immense assemblage of cane and mud tents, enclosed by a high wall. The sculls and jawbones of enemies slain in battle form the favourite ornament of the palaces and temples. The king's apartment is paved, and the walls and roof stuck over with these horrid trophies; and if a farther supply appears desirable, he announces to his general that "his house wants thatch," when a war for that purpose is immediately undertaken. 
Mr. M'Leod, during his residence at Whidah, in 1803 , found the country still groaning under the cruel effects of Dahoman tyranny. He particularly deplores the case of Sally Abson, daughter of the late English governor by a native female, who, trained in all European accomplishments, added to them the most engaging simplicity of manners. Suddenly, she disappeared, and Mr. M'Leod's eager inquiries were met by a mysterious silence; all hung down their heads, confused and terrified. At length an old domestic whispered to him that a party of the king's halfheads (as his messengers are termed) had carried her off in the night, to be enrolled among the number of his wives, and warned him of the danger of uttering a word of complaint.

A more pleasing spectacle was.presented to Messrs. Watt and Winterbottom, who, in 1794, ascended the Rio Nunez to Kakundy, and made an excursion to Foota Jallo, the principal state of the southern Foulahs. This people profess the Mohammedan religion, are orderly and well instructed, display skill in working mines of iron, and in carrying on the manufacture of cloth, leather, and other African fabrics. Caravans of 500 or 600 Foulahs were often met, carrying on their heads loads of 160 pounds weight. The article chiefly sought after is salt, which the children suck as ours do sugar; and it is common to describe a rich man by saying, he eats salt. The two principal towns, Laby and Teemboo, were found to contain respectively 5000 and 7000 inhabitants. The king could muster 16,000 troops, whom, unhappily, he employed in war, or at least hunts, against twenty-four pagan nations that surround his territory, chiefly with the view of procuring slaves for the market on the coast. When the travellers represented to him the iniquity of this course, he replied, "The people with whom we go to war never pray to God; we never go to war with people who pray to God Almighty." As they urged, that in a case of common humanity this ought to make no distinction, he quoted passages from the Koran commanding the faithful to make war on unbelievers. They took the liberty to insinuate that these might be interpolations of the Devil, but found it impossible to shake his reliance on their authenticity.

A more recent and memorable intercourse was that opened 


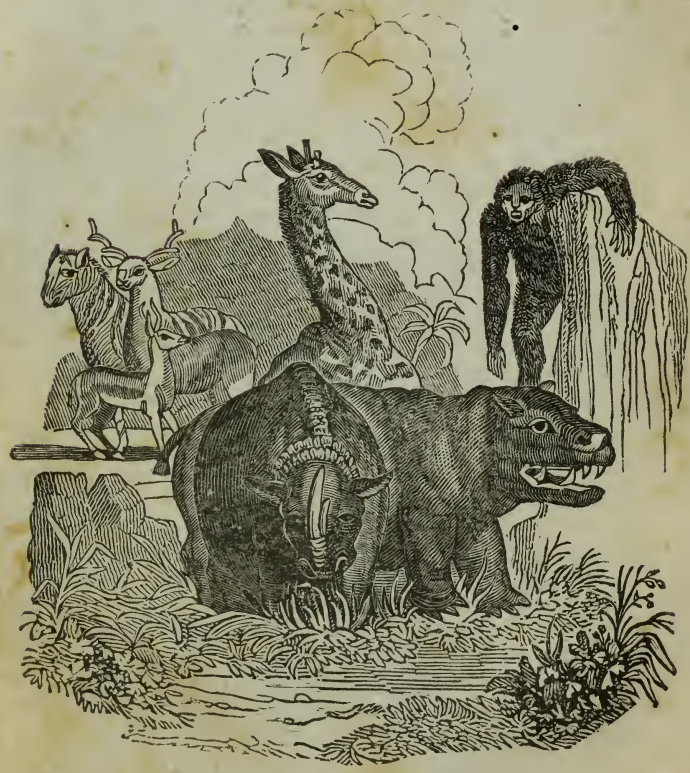

Group of African Animals-In front, in the centre, the Rhinoceros ; to the right, the Hippopotamus and Orang-outang. In the centre back ground, the Giraffe-to the left, Antelopes and Zebra,--[p. 200.] 

with the court of Ashantee. This people were first mentioned, in the beginning of last century, under the name of Assente or Asienti, and as constituting a great kingdom in the interior,- the same that was described to Mr. Lucas, at Tripoli, as the ultimate destination of those caravans which, proceeding from that city, measure the breadth of Africa. Being separated from the maritime districts, however, by Aquamboc, Dinkira, and other powerful states, they did not come inro contact with any European settlement. It was not, indeed, till the commencement of this century that these states were obliged to give way before the growing strength of the Ashantee empire, which at length extended to the borders of the Fantees, the principal people on the Gold Coast. These last were ill fitted to cope with such formidable neighbours. They are a turbulent, restless tribe, and extremely prompt in giving offence, but in battle they are equally cowardly and undisciplined. The king of Ashantee having, not unwillingly perhaps, received from them high provocation, sent, in 1808, an army of 15,000 warriors, which entered their territory, and laid it waste with fire and sword. At length they came to Anamaboe, where the Fantees had assembled a force of 9000 men; but these were routed at the first onset, and put to death, except a few who sought the protection of the British fort. The victors, then considering the British as allies of their enemy, turned their arms against the station, at that time defended by not more than twelve men. Yet this gallant little band, supported by slender bulwarks, completely baffled the fierce and repeated assaults made by this barbarous host, who were repulsed with considerable slaughter. Seized with admiration and respect for British prowess, the Ashantees now made proposals for a negotiation, which were accepted, and mutual visits were paid and returned. The English officers were peculiarly struck with the splendid array, the dignified and courteous manners, and even the just moral feeling, displayed by these warlike strangers. They, on their side, expressed an ardent desire to open a communication with the sea and with the British, complaining that the turbulent Fantees opposed the only obstacle to so desirable a purpose. A treaty was concluded, and a thoroughly good understanding seemed established between the two nations. The Ashan- 
tees, however, made several successful incursions in 1811 and 1816; and on the last occasion the Fantees were obliged to own their supremacy, and engage to pay an annual tribute. The British government judiciously kept aloof from these feuds; but in 1817 a mission was sent, under Messrs. James, Bowdich, and Hutchinson, to visit the capital of that powerful kingdom, and to adjust some triffing dissensions which had unavoidably arisen.

The mission having set out on the 22d April, 1817, passed over a country covered, in a great measure, with immense and overgrown woods, through which a footpath had with difficulty been cut, though in some parts it presented the most beautiful scenery. Being delayed by Mr. James's illness, they did not arrive at Coomassie, the capital, till the 19th May, when they were surprised at its unexpected splendour. It was four miles in circumference, built not indeed with European elegance, but in a style considerably superior to any of the maritime towns. The houses, though low, and constructed only of wood, were profusely covered

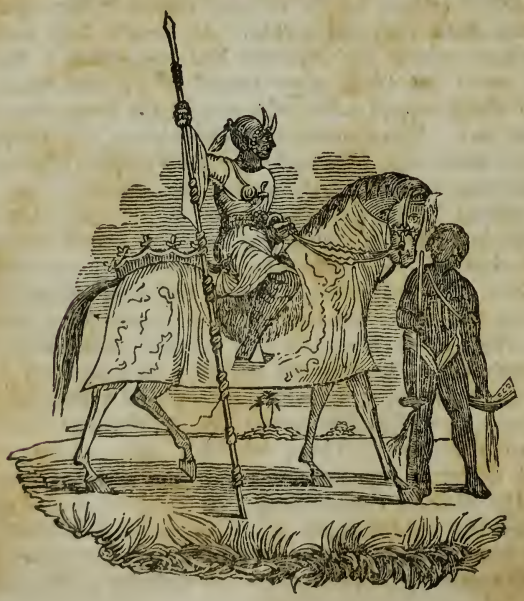


with ornament and sculpture. The array of the caboceers, or great war-chiefs, was at once brilliant, dazzling, and wild. They were loaded with fine cloths, in which variouslycoloured threads of the richest foreign silks were curiously interwoven ; and both themselves and their horses were covered with decorations of gold beads, Moorish charms, or amulets, purchased at a high price, and the whole intermingled with strings of human teeth and bones. Leopards' skins, red shells, elephants' tails, eagle and ostrich feathers, and brass bells were among the favourite ornaments. On being introduced to the king, the English found all these embellishments crowded and concentrated on his own person and that of his attendants, who were literally oppressed with large masses of solid gold. Even the most common utensils were composed of that metal. At the same time, the executioner, with his hatchet on his breast, and the execution-stool clotted with blood, gave a thoroughly savage character to all this pomp. The manners of the king, however, were marked by a dignified courtesy ; he received the strangers cordially, and desired them to come and speak their palaver in the market-place. On the presents being carried to the palace, he expressed high satisfaction, as well as great admiration of the English workmanship. After several other interviews, he entered on the subjects under discussion, which related to some annual payments formerly made to the Fantees for permission to erect forts, as well as for the ground on which they stood ; and the king now demanded, as conqueror of the country, that these payments should be transferred to himself. The claim was small, and seems, according to African ideas, to have been reasonable; but Mr. James thought himself bound to remain intrenched in the rules of European diplomacy, and simply replied, that he would state the demand to the governor of Cape Coast. The king then told them that he expected they had come to settle all palavers, and to stay and be friends with him ; but now he found that their object was to make a fool of him. Considering himself insulted, he broke through the ceremonious politeness which he had before studiously maintained. He called out, "The white men join with the Fantees to cheat me, to put shame upon my face." Mr. James having remained firm, the king became more incensed, and exclaimed, "The English come to cheat me; they come to spy the 
country ; they want war, they want war !" Mr. James merely replied, "No ; we want trade ;" but the monarch's wrath increased to such a degree, that he started from his seat, and bit his beard, calling out, "Shantee foo! Shantee foo !" and added, "If a black man had brought me this message, I would have had his head cut off before me." A singular manœuvre now took place in the diplomatic party. Mr. Bowdich, with two junior members, conceiving that Mr. James's too rigid adherence to rule was endangering the preservation of peace with this powerful sovereign, resolved to supersede him, and undertake the charge of the negotiation. They conducted it entirely to the satisfaction of his Ashantee majesty, who concluded a treaty with the English, and even made a proposal of sending two of his sons to be educated at Cape Coast Castle.

During their stay at Coomassie; the commissioners witnessed dreadful scenes, which seem to sink the Ashantee character even below the ordinary level of savage life. The custorns, or human sacrifices, are practised on a scale still more tremendous than at Dahomey. The king had lately sacrificed on the grave of his mother 3000 victims, 2000 of whom were Fantee prisoners; and at the death of the late sovereign the sacrifice was continued weekly for three months, consisting each time of two hundred slaves. The absurd belief here entertained that the rank of the deceased in the future world is decided by the train which he carries along with him, makes filial piety interested in promoting by this means the exaltation of a departed parent. On these occasions, the caboceers and princes, in order to court royal favour, often rush out, seize the first person they meet, and drag him in for sacrifice. While the customs last, therefore, it is with trembling steps that any one crosses his threshold; and when compelled to do so, he rushes along with the utmost speed, dreading every instant the murderous grasp which would consign him to death.

To cultivate the good understanding now established, the British government very judiciously sent out M. Dupuis, who, during his residence as consul at Mogadore, had acquired a great knowledge of Africa and its people. But, before his arrival, the ardour of their mutual affection had been cooled by the intervention of some clouds, which he had set out in the hope of dispelling. This mission, which. 
arrived at Coomassie early in 1820 , was well conducted, and succeeded in its object. The king renewed, in the most ample measure, his professions of desire to cultivate a friendly intercourse with the British nation; withdrew such of his demands as were shown to be inadmissible; and while he claimed full dominion over the coast, agreed that the English should exercise jurisdiction within, and even in the immediate vicinity of their own forts.

M. Dupuis found this monarch deeply impressed with respect for white men, and also with a desire to imitate and rival the pomp of European kings. He was erecting a palace, the outside of which consisted only of large logs of timber; but the interior was to be adorned with brass, ivory, and gold. He said, "Now white men know me, I must live in a great house as white kings do; then I shall not be ashamed when white people come ;"-and on another occasion, "I must have every thing suitable, and live like a white king." He had procured architects from Elmina to give instructions to his own subjects, who, however, performed the task in so awkward a manner, that he himself laughed at them, exclaiming, "Ashantees fools at work." But the want of skill was compensated by their numbers; and while engaged at work, they suggested to M. Dupuis the singular image of a legion of devils attempting to construct a tower of Babel.

The envoy had the unhappiness of being resident during the "Little Adai Custom," as it was called, and understood that in one day upwards of seventy victims had been sacrificed in the palace alone. He was not present; but waiting on the king immediately after, saw his clothes stained with blood, the royal death-stool yet reeking, various amulets steeped in gore, while a spot on the brow of his majesty and his principal chiefs indicated the work in which they had been engaged.

The government of Cape Coast Castle unfortunately did not ratify the treaty concluded by $M$. Dupuis, but undertook to support the Fantees in an attempt to throw off the Ashantee yoke. They were thus involved in hostilities with the latter people, whose sovereign, in January, 1824, entered Fantee with a force of 15,000 men. Sir Charles M'Carthy, newly appointed governor, being ill-informed as to the strength of the, enemy, marched out to meet him 
with a force of scarcely a thousand British, supported by a crowd of cowardly and undisciplined auxiliaries. The two armies met near the boundary stream of the Bossompra, where the English, soon deserted by their native allies in whose cause they had taken tho field, maintained the contest for some time with characteristic valour, till it was discovered, that through the negligence of the ordnancekeeper, the supply of powder was entirely exhausted. Thus deprived of the use of firearms, they were surrounded by the immensely superior numbers of a warlike and desperate enemy, and after a fearful contest, the particulars of which never fully transpired, the whole army either perished on the field, or underwent the more cruel fate of captivity in the hands of this merciless foe. Only three officers, all of whom were wounded, brought the dreadful tale to Cape Coast Castle. The Ashantees then overran the whole open country, laid siege to the castle, and pressed it closely for some months. Being repeatedly checked, however, and suffering under sickness and want of provisions, they retreated into their own country; nor has the king, distracted by the rebellion of some neighbouring states, ever since attempted to march down upon the coast.

Captain Adams, in the course of a trading voyage along the African shore, visited Benin, the capital of which is situated on a river coming from the north-east. The city is large, apparently containing about 15,000 inhabitants, and surrounded by a country extremely fertile, but not highly cultivated. The king of Benin is Fetiche,-worshipped by his subjects as a god, and must not on any account be supposed either to eat or sleep. Heresy against this creed is punished in the most prompt and summary manner, by instantly striking off the head of the unbeliever. With all his divine and royal attributes, however, the king does not disdain the occupation of a merchant, and drives a hard bargain while exchanging slaves and ivory for tobacco, which is a favourite luxury in this part of Africa. He is very accessible to strangers, provided they spread before him as a present a handsome piece of red silk damask. Human sacrifices are not practised to the same dreadful extent as in some other parts of Africa; yet a considerable number are offered on the graves of their great men, and four annually at the mouth of the river, as an amulet to attract vessels; 
but such is the pestilential character of the climate, that this bloody charm brings now comparatively few slave-merchants to Benin.

Captain Adams ascended also to Waree, an insular territory, enclosed by two branches of another stream flowing through this alluvial district. It is beautiful as well as fertile, is about five miles in circuit, and appears as if it had dropped down from the clouds; for all the surrounding shores consist of an impenetrable forest, rising out of a swamp. Even in the dry season the water stands on the ground a foot in depth, producing exhalations which prove excessively destructive to the European constitution, as well as to all the more delicate plants ard animals that happen to be removed from the drier soils of the interior. In other respects, this intelligent navigator did not make any material addition to the knowledge of Western Africa previously derived from other sources.

\section{CHAPTER XV.}

\section{Southern and Eastern Africa.}

THE southern extremity of Africa has long attracted the particular attention of modern navigators. To pass this mighty cape formed the main object of ambition with the Portuguese in their celebrated voyages of discovery along the African coast. After almost a century had been spent in successive endeavours to accomplish that undertaking, Diaz obtained a view of this great promontory ; but the stormy sky in which it was enveloped, and the fearful swell produced by the conflict of the contending oceans, appalled even that stout navigator. He named it the Cape of Tempests, and immediately return'd with his shattered barks to Portugal. The king, with a bolder spirit, substituted forthwith the name of Cape of Good Hope, which it has ever since retained; yet some years elapsed before the daring sails of Gama rounded this formidable barrier, and bore across the ocean to the golden shores of India.

The Portuguese, engrossed by the discovery and conquest. 
of the kingdoms of the East, and busied in lading their vessels with the produce of those vast and opulent regions, scarcely deigned to cast an eye on the rude border of Southern Africa, its terraces of granite, its naked Karroo plains, or the filthy and miserable kraals of the Hottentot. Their fleets, indeed, stopped occasionally for water and refreshments; but no attempts were made to occupy, and still less to colonize, this barren and unpromising country.

The Dutch, a prudent and calculating people, having pushed their way into the Indian seas, where they first rivalled and then supplanted the Portuguese, were not long in discovering the important advantage that might be derived from the Cape as a naval station. In 1650, they founded Cape Town,-a step which led to farther improvement ; for it thereby became necessary that supplies of grain and provisions should be drawn from the surrounding country. When, moreover, it was discovered that on some neighbouring hills the vine could be reared in high perfection, a new value was stamped upon the settlement. The natives, not then destitute of bravery, but ill-armed, undisciplined, and disunited, were easily driven back by the colonists, or reduced to an almost complete and hopeless bondage; and hence the country, for several hundred miles in every direction, so far as it afforded any herbage, was soon covered with extensive grazing farms under Dutch masters.

Peter Kolben, who resided some years at the Cape, published a narrative, which, though it be liable to a few exceptions, gives us by far the fullest account of the Hottentots, before that race was completely weighed down by European oppression. This unfortunate tribe has become noted and almost proverbial for presenting man in his lowest estate, and under the closest alliance with the inferior orders of creation. It must, indeed, be admitted, that they take particular pains to render their external appearance the most hideous that the human body can possibly present. Grease is poured over their persons in copious streams, which, being exposed to the perpetual action of smoke, forms on their skin a black and shining cake, through which the native colour, a yellowish brown, is scarcely ever perceptible. Grease in Africa forms the chief distinction of rank,the rich besmearing themselves with fresh butter, while the poorer classes are obliged to tear the fat from the bowels of 
slaughtered animals. They assign as a reason for this sin. gular practice an effect which has been readily admitted by judicious travellers, namely, that such a coating has in this climate a most salutary influence in defending them from the rays of the sun, and in averting many cutaneous disorders. Nature seems to have aided the task of disfiguring them, by covering the head with irregular tufts of hard and coarse hair, and causing singular prominences, composed of fat, to jut out in parts where they are least ornamental. Nor do their habits of life present any thing to redeem this outward deformity. Their kraals consist of a confused crowd of little conical hovels, composed of twigs and earth, in which large families sit and sleep, without having room to stand upright. The fire in the middle fills these mansions with thick smoke, the floors of which are deeply covered with every species of filth. At festivals, when an ox or a sheep is killed, the Hottentots rip open the belly, tear out the entrails, which they throw on the coals, and feast on them before the animal is completely dead. Y Yet they are a friendly, merry, hospitable race, living together in the greatest affection and harmony. The sluggish and senseless stupidity with which they have been so generally taxed, seems to have been in a great measure produced by their degrading subjection to the Dutch boors. In their free state they had a republican form of polity, and konquers or captains of the kraal, who led them to war, which they carried on with extreme fury. This commander usually sounded a pipe or flageolet, during which his men fought without intermission; but as soon as the music ceased they began to retreat. The Hottentots direct their darts and throwingsticks with a sure aim, surround and attack wild animals with skill and vigour, and evade their springs with a dexterity which no European can equal. They tan, dress, and shape skins; make mats of flags and bulrushes; also twist strings for their bows out of the sinews of animals; and even mould iron into cutting instruments with considerable expertness. In their free and happy state, they displayed the same passion for the dance and song which is general throughout Africa. A heavy reproach lies upon this race, as being destitute of all ideas of religion; and the atheist has even boasted of them as an exception to that universal belief of mankind, which is urged against his unnatural tenet. 
Supposing this assertion correct, such ignorance, which must have sprung from profound and stupid apathy, could not form any high authority on a subject so abstruse. But the faet itself, as in every similar case, has vanished before the light of more accurate observation. The Hottentot had neither temples, images, nor the pomp of a regular priesthood; but he believed in a supreme good Being, whom he viewed with distant adoration, and also in a little deformeu and malignant power, whom he sought to pacify by gifts and sacrifices. He had the usual superstitions of unenlightened men, hailing the new and full moon not only by offerings, but by shouts, cries, and dances, prolonged throughout the night. $\mathrm{He}$ attached a sacred character to certain woods, hills, and rivers, which he supposed haunted by departed friends or by the spirits of the ancient heroes of his tribe. Lastly, to come to the very lowest, the Hottentots had a little shining beetle which they had exalted almost into a deity.

About the close of the last century, Southern Africa excited a particular interest among the lovers of natural history, from the brilliancy of its floral productions, and from those remarkable forms of the animal kingdom, which, though generally diffused over that continent, could be most safely and easily studied in the vicinity of the Cape. In 1778, Captain Henry Hope, who, under the authority of the Dutch government, had penetrated into the interior of the colony with a caravan of eighty-nine persons, published at Amsterdam a work containing plates of the giraffe or camelopard, the zebra, the hippopotamus, the gnu, and other animals then almost unknown in Europe. Soon after, the whole region was carefully surveyed by two eminent naturalists, first Sparrman, and then Le Vaillant,the one distinguished by sound sense and accurate observation, the other by the splendid colouring which he succeeded in throwing over the narrative of -his personal adventures. These travellers viewed with admiration the elegant forms of the giraffe and the zebra, the light shape and bright eye of the spring-bok, the most beautiful of antelopes, and of which herds were seen covering these desert plains as far as the eye could reach. They were struck also with the odd shapes of the gnu and the quagga, combining as it were, the most opposite natures. Sparr- 
man's hunts were not very successful: he gave chase repeatedly to the gnu; but that animal, by its swift bounds, eluded pursuit. Herds of zebras were seen only at a distance; and of all the hippopotami which he attacked, he could carry off only one, three weeks old. He made a full examination, however, of the rhinoceros and the quagga, and brought to Europe the first precise account of that wonderful and destructive insect, the termes or white ant. Le Vaillant, more fortunate, conveyed to France the skin of the giraffe, as well as that of a full-grown hippopotamus. He brought also a rich collection of birds, and many specimens of those beautiful and flowering shrubs which spring up only amid the sands of the African desert.

Mr. Barrow, who, in 1797 , while private secretary to Lord Macartney, made a tour through the Cape territory, communicated more important information than any of his predecessors, and exhibited for the first time a view of the social condition of this remote colony. He found the Hottentots reduced almost universally to the condition of slaves, not transferable indeed, but attached to the soil, and not on that account the better treated. Frequent use is made of a heavy leathern thong, the lashes inflicted with which are measured not by number but time. Connecting this punishment with his favourite luxury, the Dutchman orders the flogging of the culprit to continue while he himself smokes a certain number of pipes. Even when a Hottentot engages for hire, the children born during this period of service are destined to become slaves. Nothing, in short, can more fully prove the cruel treatment of this unfortunate race, than the fact, that they do not keep up their numbers, but are gradually disappearing: at present there are not supposed to be more than 15,000 in the colony. The few kraals of independent Hottentots, which still remain on its outer border, may perhaps amount to 10,000 .

The Dutch planters or boors occupy lots of considerable extent, reaching usually to the extent of some miles in every direction; yet the nearest neighbours are engaged in almost constant feuds respecting the boundaries of these vast possessions. Their dissensions must doubtless be greatly fomented by the mode of measuring land according to the number of steps employed in walking over it. There is indeed an official pacer (felt-wagt-meester), who receives 
three dollars for every perambulation ; but this survey must always be more or less vague; and he is alleged sometimes to take partial steps in support of a favourite claimant. The boor, absolute master of these wide domains, covers them with flocks and herds, the care of which he commits to his Hottentots, - obtaining thus the entire disposal of his own time, which he devotes to the most listless indolence. He makes neither milk nor butter; nor does he produce either wine, fruits, or vegetables. The pipe never quits his mouth, except to take his sopie or glass of brandy, and to eat three meals of mutton soaked in the fat of the large-tailed sheep, without vegetables or even bread. The good lady of the house, equally disdainful of toil, remains almost as immoveable as the chair on which she sits, having before her a table, always covered with hot coffee. The daughters sit round with their hands folded, resembling articles of furniture rather than youthful and living beings. No diversion, no event, breaks the monotony of this insulated existence; nor does knowledge for them ever " unrol her ample page." XA schoolmaster, indeed, usually forms part of the establishment; but as it is thought too much to maintain one for teaching only, he is expected to make himself useful in sundry other capacities. Mr. Barrow even saw one of this learned fraternity yoked in a plough. Amid such varied avocations, these sage instructers cannot be expected to convey to their pupils more than the mere elements of reading and writing. At the same time, hospitality knows scarcely any limits. With the exception of their nearest neighbours, with whom they are probably involved in boundary feuds, any person, from any quarter, is welcome. The stranger opens the door, shakes hands with the master, kisses the mistress, sits down, and makes himself completely at home.

From Graaf-Reynet, at the eastern extremity of the colony, Mr. Barrow pushed forward without delay to the country of the Caffres, it being one main object of his journey to adjust some differences between that people and the European settlers. The first party he met after passing the boundary made the most favourable impression upon him. The females flocked and danced round the strangers, showing the utmost curiosity, and receiving with delight presents of tobacco and brass buttons, yet never trespassing 
on the limits of decorum. Their persons were somewhat short and stunted, and the skin of a dark glossy brown; but the features were almost European, and their dark sparkling eyes bespoke vivacity and intelligence. The men, again, were the finest figures that the traveller had ever seen, considerably above the middle size, robust, and muscular, yet marked with the most elegant symmetry. Their deportment was easy, and their expression frank, generous, and fearless. In reply to the complaints which were made of their encroachments upon the territory of the colony, they asserted, and seemed to prove, that much greater encroachments had been made by the colonists themselves, and expressed their readiness to accede to any arrangement which might obviate future dissension,- - stating, however, that nothing could be done but through Gaika, the great king of the Caffres. The umpires immediately proceeded towards his residence, through a beautiful, but uncultivated, and somewhat entangled country. $\mathrm{He}$ was absent at the moment, employed in pursuing a band of wolves; but his wife and mother, with fifty or sixty attendants, sat round the strangers, and conversed, through an interpreter, in the most agreeable manner. At length the monarch was seen approaching at full gallop, mounted on a handsome ox. Alighting from this singular charger, he graciously welcomed the strangers, and seating himself and his attendants under the shade of a mimosa, immediately entered upon business. He showed himself extremely reasonable in every respect, declaring, that whatever inroads had taken place on the frontier were without his knowledge or sanction, and he agreed at once to a code of regulations which might put an end to future aggression. It seems probable, indeed, that had the wise and conciliatory measures which Mr. Barrow suggested been steadily adhered to, all collision might have been avoided with this manly and warlike race.

The Caffres are perhaps the most completely pastoral people in existence. Their agriculture is very limited, owing to their roaming mode of life. Game is scarce, and they make no use of their extensive line of seacoast for fishing; but the management of cattle is thoroughly understood, being carried on by the men, who not only tend but milk the cows, and who, by a particular modulation of 
the voice, send out a herd to graze, or recall it at pleasure to the enclosures. A cow is never killed but on high occasions, milk, with roots, forming their standard diet. Skill is shown in several arts, such as making baskets of grass, sharpening iron by stones, without being able to smelt it, and dressing calf-skins for their apparel. Polygamy is lawful; but as a wife costs an ox, or two cows, the practice is confined to the rich.

After returning to Graaf-Reynet, Mr. Barrow passed across the Great Karroo, or desert, covered with scanty and useless vegetation, yet presenting spring-boks, ostriches, and other wild animals, which roam in large herds, and the most beautiful flowers, which spring up amid the sand. He then came to the borders of the Sneuwberg, or Snowy Mountains, the streams from which cover an extensive district with luxuriant herbage. The colonists there are kept in a state of greater activity than elsewhere, by the dread of wild beasts, and of the still wilder race of Bosjesman Hottentots, whose kraals occupy the intermediate valleys. They pursue and hunt down these unhappy creatures, as if they were the natural enemies of the human race. Mr. Barrow mentions a young fellow who had made a journey along part of that mountain-range ; and on his return, being asked if he had seen many Bosjesmans, replied, with a disappointed air, that he had only shot four. These savages, in their turn, carry off all the cattle they can find, and put to a cruel death every one who falls into their hands, whether he be Dutch or Hottentot. Each party throws upon the other the blame of this mutual hostility. Mr. Barrow took some pains to acquire information respecting that unfortunate race. His party having succeeded in surprising a kraal, the natives sprung out of their little mat-huts with cries resembling the war-whoop of savages, and flew to the top of a neighbouring hill. From inveterate habit it was impossible to prevent some bloodshed; but at length, by persevering kindness, several were induced to come forward and hold communication with the English. They proved to be the ugliest of human beings. Their hollow backs, projecting bellies, and prominent posteriors, caused the body to assume nearly the form of the letter $S$, which, though by some painters described as constituting the line of beauty, produces, in its application to the human shape, 
an effect very strikingly the reverse. In their condition, too, they are, of all rational beings, perhaps the most forlorn and wretched. Their only mode of obtaining food is by scrambling over the rocks after wild animals, digging the earth for some unsavoury roots, devouring the larvæ of ants and locusts, and, finally, in wild foray, carrying off the cattle from the adjoining plains. Yet the habits arising from this precarious subsistence create a degree of energy which does not arise when man slumbers in the lap of ease and abundance. Hence, this people indulge even in an extravagant gayety, which forms a striking contrast to the gloomy dejection of the enslaved Hottentots. On moonlight nights they dance without intermission from sunset till dawn ; and, on the prospect of fine weather, sometimes continue this exercise for several days and nights. Their little arrows, tipped with poison, are shot with surprising dexterity ; and the warriors bound from rock to rock with an agility which baffles all European pursuit. They endure long fasts, which render their bodies usually very lank and meager; but when they make a capture of cattle or sheep, they devour the flesh in a disgusting manner, and in the most amazing quantities. Mr. Barrow having given to three of them a sheep about five in the evening, saw it entirely consumed by twelve next day, when their formerly lank, lean bellies were distended to an extraordinary size. The pictures of animals, drawn on the rocks with no inconsiderable spirit and correctness, showed at least the rudiments of art and talent.

The knowledge of Europeans respecting the Cape territory had hitherto been confined by the Karroo Desert, and the formidable range of the Sneuwberg beyond it. In 1801, a scarcity of cattle being felt, Messrs. Trutter and Somerville undertook an expedition, with the view of obtaining a supply in some of the more remote districts. Having passed the Snow mountain and the country of the Bosjesmans, they came to the Orange river, a broad stream flowing westward to the Atlantic, and on the banks of which were the Koras or Koranas, a pastoral people with numerous herds. The information here received induced them to proceed into the country of the Boshuanas, which continued to improve as they advanced, till, to their utter surprise, in the midst of these savage wildernesses of Southern Africa, 
they found a regular city. Lattakoo was composed of two or three thousand houses, neatly and commodiously built, well enclosed and shaded from the sun by spreading branches of the mimosa. The country around was not only covered with numerous herds, but showed considerable signs of cultivation. The king, a venerable old man, invited them to his house, and introduced them to his two wives. The travellers met every where a kind and hospitable reception, and were the objects of an eager but friendly curiosity. Their report, in fact, encouraged the idea that the golden age had once more revived in the centre of Africa.

The Cape government afterward undertook to follow up this discovery. Lord Caledon sent Dr. Cowan and Lieutenant Denovan, at the head of a party of twenty men, with instructions to strike across the continent in a south-eastern direction, and by endeavouring to reach Mozambique, to connect the two great points of African geography. The travellers passed Lattakoo, and accounts were received from them nearly eleven days' journey beyond it, when they were in the midst of a richer and more beautiful country than they had yet seen in Southern Africa. A long and anxious interval had elapsed, when the governor sent a fastsailing vessel to Sofala and Mozambique, the captain of which was informed that the expedition had come to a most disastrous issue. It was stated that the party, having arrived in the dominions of the king of Zaire, between Inhambane and Sofala, had been attacked in the night, and all cut to pieces, with the exception of two individuals. Mr. Campbell was afterward assured, that the catastrophe had taken place among the $\mathrm{W}$ anketzen;, a nation immediately beyond Lattakoo, where the travellers, trusting to the friendly behaviour and professions of the people, had neglected the most common precautions. The officers went to bathe, leaving one party in charge of the wagons, and another to guard the cattle. Thus split into three divisions, they were successively attacked and destroyed by the treacherous barbarians.

Dr. Henry Lichtenstein, after surveying several of the Cape districts, extended his journey to the territory of this newly-discovered people, accompanied by one of the natives, named Kok, who had been for some time absent from his 
country. The first party whom they met accosted them with such demonstrations of kindness and cordiality, as impressed our traveller with the most favourable opinion of their character, and relieved some apprehensions under which he had laboured. The inhabitants, tor, of the first village at which they arrived received them in a manner quite frank and hospitable, though they showed rather an excessive eagerness to obtain a supply of t sbacco. Crossing the river Kuruhman, and proceeding by a winding path through a noble forest, they reached I/ttakoo. The curiosity excited by their arrival soon aitracted a crowd so immense, as to make it impossible for the wagons to proceed; but still the multitude appeared to be animated by the most friendly sentiments. The venerable old king next appeared, and promised to pay them an early visit. On a pipe of tobacco being presented, he began to inhale the smoke by large drafts, and after being satisfied, handed it to his prime minister, who transmitted it to the next in dig. nity ; thus it passed from mouth to mouth, till it reached the lowest of the attendants. The king afterward introduced the Doctor to his two wives, of whom the principal one, Makaitshoah, dazzled him by the beauty which had raised her from a low degree to the station that she now occupied. She was loaded with a profusion of African finery, - a mantle trimmed with rich furs, and fastened to the shoulder by a bundle of cats' tails, sundry necklaces of bone, copper, and cral, and on one arm no less than seventy-two copper rings, on which she seemed to set the highest value; she displayed, and saw them counted with peculiar delight. The ladies paid a very long visit, but showed little regurd for tea, which was at first presented as most suitable to their rank and sex ; while wine, and more especially brandy, were highly relished by them. In the course of a long conversation, the lot of European wives, in having each a husband to herself, became, as usual, the favourite theme ; but Makaitshoah, though she approved of the system in general, thought that in Africa, where the waste of war was so great, polygamy, to a certain extent, was necessary to keep up the numbers of the nation.

Dr. Lichtenstein had intended to proceed considerably farther into the interior; but his views were changed, by a proposal earnestly pressed upon him by the king to accom- 
pany, and assist with his firearms, an expedition which his majesty was about to undertake against his neighbour Makkrakka. Finding that he could not remain without involving himself in the deadly feuds of these African chiefs, he chose rather to return to the colony.

Mr. John Campbell, animated by the benevolent desire of imparting to this people the blessings of true religion, undertook, in 1813, a mission into Southern Africa. Passing the Sneuwberg in the same direction that had been followed by Messrs. Trutter and Somerville, he reached Lattakoo, which, by a change not unusual in Africa, had been moved about sixty miles to the southward of its original situation; but the new city had not yet attained more than half the dimensions of the old. His reception was at first marked by a peculiar caution and jealousy. Not a sound was heard in the city; and he walked through empty streets till he came to the great square in front of the palace, where several hundred men were drawn up armed and in battle array. All this precaution was found to have been suggested by the fear that he and his companions were sent to avenge the death of Dr. Cowan and Mr. Denovan; but no sooner were the inhabitants satisfied that he came with no commission from government, and with no hostile object, than they crowded round him with their usual frankness, and eagerly begged for tobacco. Soon after, Mateebe, the king, entered with a numerous train of attendants, bearing spears tipped with ostrich feathers. He did not, in passing, take any notice of the English strangers, but irimediately after admitted them to an interview, though without giving them quite so gracious a reception as they could have wished. He particularly demurred to the proposal of founding a mission at Lattakoo, on the ground or pretence that it would interfere with the tending of their cattle and other occupations; but this being Mr. Campbell's favourite object, he pressed it so earnestly, and represented, in such flattering terms, the superior wealth and industry of Europeans, that Mateebe at length gave his consent to the establishment of missionaries, and promised to treat them well.

Mr. Campbell's observations finally dissipated all that yet remained of the original illusion, which had represented this people as enjoying at once the innocence and the 
felicity of the primitive ages. There was, indeed, as not unfrequently happens in uncivilized life, a courteous, kind, and friendly spirit towards one another. But between neighbouring tribes the enmity is as deadly, and the laws and practices of war as barbarous, as among the rudest of African hordes. The missionary, with the view of paving the way for religious instruction, having asked one of them what was the chief end of man, received an immediate answer, "For commandos,"-the term by which they express their raids or forays undertaken for the purpose of stealing cattle. With the profit of carrying off the herds, they seek also to combine the glory of killing the warriors to whom they belong. The number of men whom they have slain forms their chief boast ; in which estimate they reckon one white equal to two blacks.

In 1820, Mr. Campbell, supported by the Missionary Society, undertook another journey into this district of Africa. $\mathrm{He}$ found the Christian establishment at Lattakoo in a somewhat flourishing state. There was a chapel capable of containing about 400 persons, and a row of good houses with gardens for the missionaries. But the friendly conduct of the natives towards that body had not been accompanied with any disposition to embrace, or even to listen to their doctrines. The Boshuanas, more perhaps than any other barbarians, seem to labour under a peculiar thraldom to the senses, and an utter disregard for all lofty and spiritual ideas. Beads for ornament, cattle for use, commandos or forays for the display of valour and activity, absorb their whole attention, and leave no room for any higher objects. The number assembled to see the missionaries dine was three times greater than could ever be induced to convene to hear them preach.

At Lattakoo Mr. Campbell met Kossie, king or chief of Mashow, and obtained permission to visit him, which, though expressed in rather cold and haughty terms, his zeal induced him to embrace. The road lay through a delightful country, consisting neither, like most parts of the Cape territory, of a naked desert, nor, like some others, of an impenetrable forest, but of a boundless meadow of luxuriant pasture, interspersed with numerous clumps of trees, appearing at a distance like a continued wood, but gradually opening as he approached. These fertile plains are 
tenanted only by a few roving Bushmen; for so incessant and destructive are the wars carried on, even among the Boshuanas themselves, that they are obliged to concentrate in the immediate vicinity of their towns. Of these, the first they came to was Meribohwey, the capital of a chief named Tammahoo, where the warriors rushed forth to meet them dressed in the skins of wild beasts, painted red, and furiously brandishing their spears and battle-axes,-rather an astounding welcome to the worthy missionaries, though it was found to be all meant in kindness. They came next to Mashow, beautifully situated on a hill surrounded by a number of lesser eminences. Within a circuit of twenty miles there were twenty-nine villages, with an almost uninterrupted cultivation. The inhabitants are estimated at 10,000 or 12,000 , and their houses and modes of life are somewhat superior to those of Lattakoo.

From Mashow Mr. Campbell passed through a country continually improving in richness and beauty, and intersected by several streams that appeared to direct their course to the Indian Ocean. At length he reached Kureechane, which is thought entitled to the appellation of a city; and, at all events, its construction, and the arts practised in it, were decidedly superior to any thing yet seen in Southern Africa. The natives smelted iron and copper in large clay furnaces; their houses were surrounded with good stone-enclosures; while the walls of mud were often painted, and moulded into pillars and other ornaments. Well-fashioned vessels of earthenware were used for holding their corn, milk, and other stores ; and considerable ingenuity was shown in the preparation of skins. A certain extent of land, immediately round the town, was under cultivation, while a larger portion beyond was devoted to pasturage; but it was necessary that the cattle should every night be brought within the protection of the town.

At Kureechane Mr. Campbell witnessed, on the largest scale, the peetso or African council, where the assembled chiefs act so extravagantly, yet speak with so much judgment, as makes it difficult to say whether they are sages or madmen. Even in their way to the meeting these savages indulge in strange gambols, making immense leaps into the air, brandishing their weapons, as if to attack and 
sometimes to stab an enemy. The circle being formed, they all join in a song, which the principal person often follows with a dance. Each chief, as he rises, prefaces his speech with three tremendous howls or yells, sometimes imitating the bark of a dog. Several of his attendants then spring forward and dance before him,-an accompaniment never omitted, even when the age and stiffened limbs of the performers render it altogether ludicrous. At length comes the speech, replete with frankness, courage, often with good sense, and even with a rude species of eloquence. On some occasions the speakers do not hesitate to pour the severest reproaches on the king, who retorts with bitterness, but never resents in any other shape. The females, meantime, stand behind, and take an eager interest in the debate, - cheering those whose sentiments they approve, or bursting into loud laughter at any that they consider ridiculous.

Mr. Campbell, on his return, took a direction somewhat to the westward, and found himself on the borders of an immense desert, which he thinks may be called the Southern Sahara. A party engaged in a plundering expedition were said to have spent two months in reaching Mampoor, its opposite extremity, which was found situated on the ocean. His conclusion, however, that this desert reaches nearly to the equator is very hasty, since the route which he mentions evidently extended, in a great measure, from east to west.

Mr. Burchell, in 1812, made a pretty extensive journey through this part of Africa. He did not reach quite so far as his predecessor ; and the account of his progress beyond Lattakoo has not yet appeared. At that city he spent a considerable time ; and his diligent observations of nature and society, animated by a fine vein of philosophical reflection, give a considerable interest to his narrative.

That rude equality which had been remarked among all the tribes of the Hottentot race was found here giving way to very marked distinctions, chiefly supported by wealth, which those in power sought the means of increasing, in their incessant wars and plunder; yet their dignity is not accompanied with that haughty separation from the inferior classes which exists in Europe. Mateebe, called here Mattivi, chief or king, used to squat himself $\mathrm{T} 2$ 
on the ground, chatting and exchanging pipes with the lowest of his people. Although, of course, their manners can boast no great refinement, they are neither boisterous nor vulgar; but a frank and easy deportment distinguishes all classes. Industry is held in honour; the chiefs tend and even milk the cows, while the women build the houses, cultivate the ground, and prepare clothes and furniture. On one occasion they gave good proof of their honesty; for, when the traveller's cattle had run away and mingled with immense herds of their own, they sought them out and brought them back to him. In begging, however, they are most ceaseless and importunate. At Mr. Burchell's first entrance they observed a certain degree of ceremony, and only one solitary cry for tobacco was heard; but this feeling of delicacy or decorum soon gave way. Mattivi himself made a private request that the presents intended for him should not be seen by the people at large, by whom they would soon be all begged away. They seemed to have more pride in what they procured by solicitation than in a thing of greater value if received as a spontaneous gift. There was hardly any appearance of police ; even murder passed with impunity, though among themselves it was not frequent. They had no temples, and nothing which Mr. Burchell thinks can be called religious worship; but, in return, they had every form of superstition, which is generally the sole substitute for religion in unenlightened societies.

The last visiter to Lattakoo was Mr. Thornpson, who, in 1823 , found that city in a state of great danger and alarm. Rumours poured in of an immense host of black warriors coming from the north and the east, who were said to be plundering and destroying every thing before them. They had already sacked Kureechane; and being repulsed from Melita, capital of the Wanketzens, were marching directly upon Old Lattakoo. whenee, it was apprehended, they would advance to the modern city. It was added that they were cannibals, and were led by a giantess with one eye ; but, amid all this exaggeration and falsehood, the reality of the dangee was undoubted. The Boshuanas immediately summoned a peetso, and formed the manly resolution of going out to meet the invader; but all who knew them were aware that they would fight only by ambuscade and under cover, anil wovild take to flight as soon as the enemy should make 
a serious attack. The missionaries, in this extremity, made great exertions to save the nation. One of them hastened back to implore the aid of the Griquas, a people bordering on the English colony, and who had learned the use of firearms from the Europeans. Mr. Thompson and another went out to trace and report the progress of this formidable inroad. On reaching Old Lattakoo they found it silent and uninhabited, like the most desolate wilderness ; while the pots boiing on the fires showed that'its desertion was recent, and that the enemy were probably at a very short distance. Notwithstanding, they continued to ride on, till, arriving at the top of a hill, their guide cried out, " the Mantatees !" who were in fact seen moving in an immense mass along the valley beneath. It was necessary to put spurs to their horses, in order to escape the hazard of being surrounded.

The arrival of Mr. Thompson at Lattakoo spread a general alarm; for so rapid was the Mantatee march, that only a little time could elapse before they would reach the city. The queen, with her female attendants and the principal chiefs, rushed into the house to ask the advice of the missionaries in this fearful crisis. The general opinion was in favour of flight. Even the warriors, who had been poisoning their arrows and dancing the war-dance whole nights without intermission, gave up all hopes of successful resistance, and were preparing to follow the long files of oxen, on which the inhabitants were already placing their most valuable effects. Suddenly a cloud of dust was seen in the south, which, on its nearer approach, announced the first division of Griqua horse coming to their aid. Hereupon, all who were endued with any portion of courage determined to remain and face the enemy. The allies were received with unbounded exultation; many oxen were killed and roasted, and even at this critical moment the two parties gave themselves up to feasting and jollity. Their security increased, when notice was received that the Mantatees still remained at Old Lattakoo, consuming the cattle and provisions which they had found in that place. Several of the missionaries then set out to endeavour to open a negotiation. On coming within sight of the enemy they rode forward in a peaceful manner, inviting them by sigms to a conference; when instantly that savage host 
raised a hideous yell, and rushed forward so rapidly, throwing their spears and clubs, that the Christian plenipotentiaries found the utmost difficulty in galloping out of their reach.

The allied force now came up, and on the following morning offered battle to the vast army of the Mantatees. Their aspect was truly frightful. They were almost quite black, with only a girdle round their loins; their heads were crowned with plumes of ostrich feathers ; they had numerous brass rings about their neck and legs, and were armed with spears, javelins, battle-axes, and clubs. Their whole body, which was supposed to amount to at least 40,000 , rushed forward in an extended line, endeavouring to enclose the little troop opposed to them. The Boshuanas gave way as soon as they were seriously attacked; the Griquas, on the contrary, kept up a close fire, which stunned the enemy, who still, however, continued to advance. The horsemen galloped back to some distance, then alighted, and again alternately fired and retreated, repeating this mancuvre for several miles. The Mantatees pressed on with the utmost fury, confident, if they could once come to close quarters, of annihilating in an instant the handful of troops opposed to them; but finding that all their efforts were vain, and seeing their bravest warriors falling rapidly, they paused, and began slowly to retire. The Griquas pursued, but were several times exposed to extreme danger by the enemy turning suddenly round and renewing the combat. At length the Mantatees set fire to Lattakoo, and retreated through the flames. The missionaries were now deeply shocked by the base and barbarous conduct of the Boshuanas, who, after their pusillanimous behaviour in the field, began not only to plunder, but to butcher the wounded as well as the women and children left on the field; nor was it without great difficulty that they succeedec in saving some of these defenceless objects.

The name Mantatee, which signifies wanderer, applies, it is said, in no other respect to this desolating horde. They appear to be a Caffre tribe, inhabiting the country near Cape Natal, along the lower course of the river Mapoota. They were impelled to this inroad, in consequence of having been driven from their own possessions by the Zoolas, a still more fierce and warlike race, who, on that occasion, were 



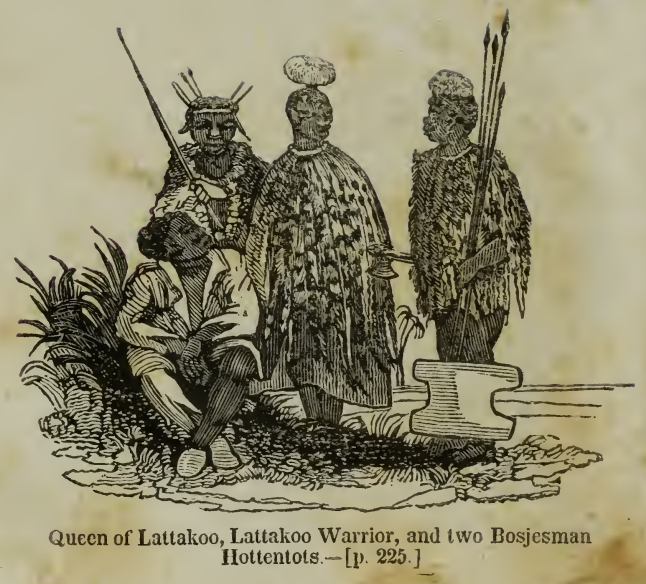


led to victory by their king, Chaka, who can arm 100,000 fighting men, and has 15,000 constantly ready for war. A small English settlement has been formed on his maritime border, which is encouraged by that powerful chief with a view to commercial advantages ; but of course much precaution is required in dealing with a potentate who commands so many savage bows and spears.

The Mantatees, after their defeat, separated into several detachments, one of which settled among the Kureechanes, while another advanced against the Caffres, whom they-defeated, and part of whose territory they have since continued to occupy and plunder. In 1826, they came within two days' journey of the British frontier, where there was nothing to prevent them from advancing upon the Scotch locations in Albany ; but measures have since been taken, by which these settlements are placed in full security.*

We possess only a very limited knowledge respecting the eastern coast of Africa, washed by the Indian Ocean,- - a region scarcely visited except by the Portuguese, who continued to throw a veil of mystery over all their discoveries. In 1498, when Vasco de Gama had rounded the Cape of Good Hope, he touched at Mozambique, Mombasa, and Melinda, where he found the ruling people Arabs and bigoted Mohammedans. His object was merely to obtain pilots to guide his fleet to India; but at the two former of these ports he met an inhospitable and treacherous reception; while, on the other hand, he experienced at Melinda the utmost courtesy, and readily found the means of continuing his voyage to the coast of Malabar. Cabral, who followed in the footsteps of Gama, likewise visited Quiloa, which he describes as the capital of an extensive kingdom, and the seat of a flourishing trade; but it was not till he, too, reached Melinda, that he could obtain any friendly assistance.

The Portuguese, engrossed for some time with the more brilliant objects presented by the shores of India, sought in African ports only refreshment and pilots, and made no attempt at conquest. As their empire, however, extended, resentment or ambition furnished motives for successively attacking those settlements. In 1505, Almeda, indignant

* The group in the annexed plate represents the Queen of Iattakoo, a Lattakoo warrior, and two Bosjesman Hottentots. 
at the reception given to him at Quiloa and Mombasa, landed and took possession of both these cities. In 1508, permission was obtained to erect a fort at Mozambique, by means of which the Portuguese soon expelled the Arabs, and became complete masters of the town. Attracted by its vicinity to the gold mines, and its convenience as a place of refreshment for their fleets, they made it the capital of their possessions in Eastern Africa. Melinda also, which had long shown such a friendly disposition to Europeans, became at last unable to endure the insulting spirit of the Mohammedans; a quarrel arose, and that city was added to the dominion of the Portuguese. They were now masters of an immense range of coast, fully 2000 miles in length, on which they held all the principal positions, "though without extending their sway to any distance into the interior.

About 1569, the Portuguese made two vigorous attempts, under Nugnez Barreto and Vasco Fernandez, to advance into the country behind Mozambique, chiefly with the view of reaching the mines of gold, the produce of which was brought in considerable quantities down the Zambese to Sofala. They penetrated a considerable way up the river, on the banks of which they erected the forts of Sena and Tete. Its upper course was found overhung by steep and precipitous rocks, belonging to the mountainous range of Lupala, which here crosses its channel. They arrived at Zimbao, the capital of Quiteve, or king of Motapa, and even at the gold mines of Manica; but, instead of the expected profusion of this precious metal, they found that, as in other parts of Africa, it was laboriously extracted in small quantities from the extraneous substances in which it is imbedded. On this expedition they had frequent encounters with the natives, who were always beaten in the field; but the Europeans were so harassed by long marches, and by the scarcity of provisions, that they finally returned in a very exhausted state, and without having been able to establish any permanent dominion over that vast extent of country.

As the energy of the Portuguese government declined, its sway over these colonies was reduced within limits which always became narrower. In 1631, the people of Mombasa rose, made a general massacre of the Europeans, and re-established their independence. About the end of the 
seventeenth century, the imam of Mascat, a powerful Arabian prince, drove them out of Melinda and Quiloa. Their possessions are now confined to Mozambique and Sofala, and are maintained even there on a very reduced scale. The former of these stations, when visited by Mr. Salt in 1808, was found to contain less than 3000 inhabitants, of whom only 500 were Portuguese ; and the fortifications were in so neglected a state, that an Arabian chief assured the traveller that with 100 stout followers he could drive the subjects of Portugal out of this capital of Eastern Africa. Yet the government-house, in its interior arrangements, still exhibits some remains of the ancient splendour of the viceroys. The entertainment of tea, which is open every evening to all the respectable inhabitants, is set out in a service of pure gold; and the negroes in attendance are absolutely loaded with ornaments of that metal. Mozambique has still a pretty considerable commerce in gold, ivory, and slaves, brought down from the regions of the Upper Zambese. These captives, since Britain shut against them the markets of the Cape of Good Hope and Mauritius, have been, to the number of about 4000 in the year, sent chiefly to Brazil.

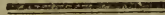 \\ CHAPTER XVI. \\ On the Social Condition of Africa.}

Having commenced this work by a general survey of Africa as it came from Nature's hand, we shall conclude with taking a rapid sketch of the changes made by man,the societies formed on its immense surface; its arts, its industry, its social and moral existence; noticing, finally, the few attempts which Britain has made to establish colonies on that continent.

A grand distinction must here be made between the native inhabitants of Africa and the foreign races from Arabia and other Asiatic countries, by whom so large a portion of its surface has been occupied. This distinction we shall 
rest, not upon supposed resemblances of form and figure, or faint analogies between the language of distant nations, but upon the introduction, within the limits of authentic history, of a people, manners, and religion belonging to another continent. The changes now mentioned were effected, in a great measure, by the inroads of the Arabs or Saracens, and afterward by the conquests of the Turks, events which have diffused over the northern half of Africa a social system every way different from that of the tribes by whom it was formerly inhabited. We shall begin, however, with considering the native races who at present people this quarter of the globe.

The native tribes of Africa exist generally in that stage of society which is denominated barbarian. They are elevated above the hunting or savage state, by the power of taming and subjecting the lower animals, and by a certain rude agriculture which the fertility of the soil renders productive. Yet few of them are nomadic and wandering like the Arabs or the Tartars : they generally have native seats, to which they cling with strong feelings of local attachment. Even the tenants of the Desert, who roam widely in quest of commerce and plunder, have their little watered valleys, or circuit of hills, in which they make their permanent abode.

Agriculture, including pasturage, forms the most important branch of industry in every society, and more especially in one where all the finer arts are yet in a state of infancy. In Africa, however, both the extent of cultivation and the processes employed are still extremely imperfect. This is particularly manifest from the fact that no private property in land has been any where established. Every city or village is encircled by an unoccupied domain of forest or waste, belonging to the king or the state, and of which a portion is ready to be granted to any one who will undertake the labour and expense of cultivation; while the remainder forms an immense common, on which all the inhabitants have the liberty of pasturing their cattle. There are in Africa no country-seats, no rural farms, such as embellish the aspect of an European landscape; and which, in fact, could not exist in safety, where each little state is begirt with hostile neighbours, and so many predatory bands are prowling in every direction. The population is col- 
lected in towns or large villages, round which a circle of cultivation is formed; while beyond are pasture-lands where numerous herds are fed, and watched by day as well as by night. The space within the walls forms a pretty wide district, where, even in the largest cities, the houses are interspersed with cultivated fields, and the low roofs are seen rising behind ears of corn. All the processes of preparing the ground, sowing, and reaping, are slight and simple. The plough has not passed the limits of Barbary; and perhaps, in tropical climates, the deep furrow which it lays open might expose the soil too much to the parching effects of a burning sun. Grain is raised only by means of the most profuse moisture, which of itself softens the earth. As soon as the periodical floods have deluged the ground, or the temporary river inundation has retired, the labourers walk forth; one slightly stirs the earth with a hoe, while another, close behind, deposites the grain. Frequently this toil is lightened, from being performed by the whole village in common, when it appears less a scene of labour than a gay festival, like our English period of reaping. The village musician plays the most lively airs; the labourers keep time to his tune; and a spectator at a little distance would suppose them to be dancing instead of working. Irrigation, in all tropical climates, is the grand source of fertility; and wherever industry has made any progress, very considerable pains are taken to collect and distribute the waters, which either fall in rain, or are conveyed by river channels. Egypt is well known to owe its fertility altogether to the canals which diffuse over its plains the water of the Nile; and in Nubia, where the current remains constantly sunk in its rocky bed, there is a succession of sakies or wheels, by which it is raised, and conducted over the adjoining fields. In this way a belt of cultivation, of about a mile in breadth, is perpetuated along the whole upper course of that great river.

In all the tropical and more arid regions, the prevailing grains are of inferior character, coarse, and small,-rather, as Jobson says, like seeds than grains, and fitted less for bread than for paste or pottage. The dhourra is the most common, extending over all Eastern Africa; while millet in the west, and teff in Abyssinia, are productions nearly similar. In the latter country and Houssa, both wheat and rice are 
raised, but only in favourable situations, and for the tables of the more opulent. Perhaps the greatest exertion of agricultural industry is that bestowed upon the culture of the manioc, which forms the main article of food in Congo and some of the insular territories. Considerable care is required in rearing it, and cleaning the ground round the plants; after the root, which is the valuable part, has been dug up, it must be ground in a species of mill, and dried in small furnaces, before it can be used as flour. The process is represented in the accompanying plate.

Manufactures, in a country where men are contented with the simplest accommodations, cannot attain any high importance. There are, however, certain fine fabrics peculiar to Central Africa; of which the most general is cotton cloth, produced in several districts of a very beautiful texture, dyed blue with fine indigo, and receiving from the processes employed a very brilliant gloss. Leather in Houssa is dressed and dyed in the same rich and soft style as in Morocco; and probably, in both cases, the manufacture is native. Mats, used both for sitting and sleeping on, are the staple manufacture in many parts of Westerm Africa. Gold and silver ornaments are made with some taste ; and iron is generally fabricated, though with a varying and imperfect degree of skill.

The tribes of Africa have scarcely in any instance arrived at the first rudiments of maritime commerce. The circuit of that continent presents no spacious inlets of the sea,-no deep bays to cherish the growth of infant navigation. Even the great lines of river-course are little if at all subservient to the purposes of inland communication, but are often so situated as to obstruct the career of the traveller, who crosses them in canoes hollowed out of a single tree, or on slight and dangerous rafts. Almost all the commerce of Africa is carried on by land. Caravans, kafilas, or coffles, cover all the routes, and connect the most distant extremities of the continent. These are formed by a union of traveliers, an arrangement strictly necessary for mutual aid amid the difficulties and perils by which almost every track is beset. The native traders do not employ camels, which have been introduced by a foreign race from Arabia into the northern deserts, for which they are perfectly adapted. The wagon, and indeed every species of 


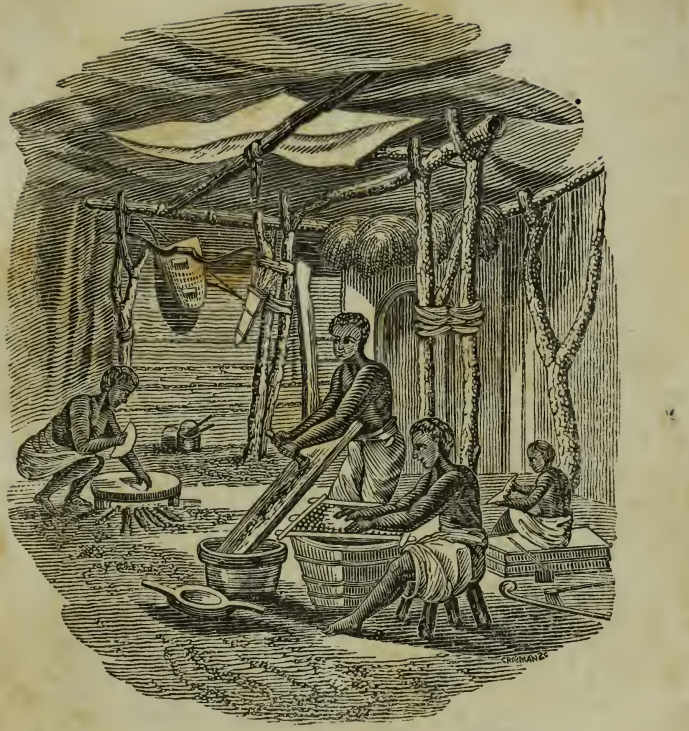

Negroes preparing the Manioc Root.-[p. 230.] 

draught, is nearly unknown, and would be ill suited to the African roads, the best of which are narrow paths cut through thick and entangled forests. In the hilly and central districts, either the back of asses, or the head of slaves and women, serves as the ordinary vehicle.

The largest branch of the native trade of Africa originates in the great demand for salt, and the longing desire which is felt for it in all the provinces to the south of the Great Desert. This commodity is chiefly brought from the seacoast ; from large pits in the Western Desert ; and also from the lakes or ponds of Domboo, in the country of the Tibboo. In like manner, from the west are sent up cowries or shells, the chief currency of the interior kingdoms, and goora or kolla nuts, a favourite luxury, which, on account of the agreeable taste they impart to the water drunk after them, are called African coffee. The returns are made in gold, ivory, fine cloths, and too often in slaves. The trade with Northern Africa across the Desert consists in foreign commodities. The chief imports are gaudy and glittering ormaments; for the power of distinguishing between the genuine and the false in finery does not seem to exist beyond the Sahara. Captain Lyon enumerates nine kinds of beads, silks, and cloths of bright colours, especially red, copper kettles, long swords, powder, and ball. Antimony to blacken the eyes, with cast-off clothes, and old armour, find also a ready market. The returns are the same as those sent to the shores of the Atlantic. The monetary system of the negro countries is most imperfect; for the shell currency, of which it requires several thousand pieces to make up a pound sterling, must be intolerably tedious. The only metallic form appears in Loggun, where it consists of rude bars of iron. In Bornou, and sereral countries on the coast, cloth, mats, or some other article in general demand, is made the common measure of value.

All the accommodations of life throughout this continent are simple and limited in the greatest degree. There does not, probably, without some foreign interposition, exist in Africa a stone house, or one which rises two stories from the ground. The materials of the very best habitations are merely stakes of wood plastered with earth, built in a conical form like bee-hives, and resembling the first rude shelter which man framed against the elements. Many of 
these mansions afford little facility for standing upright, and indeed are resorted to chiefly for sleep and shelter, while the court before the door, shaded by the family tree, is the scene of social intercourse, and of all meetings for the purposes of business and gayety. Greater efforts indeed are made to form a commodious state-room or public hall, called the palaver-house ; yet this, too, consists merely, as shown in the annexed plate, of a large apartment, raised

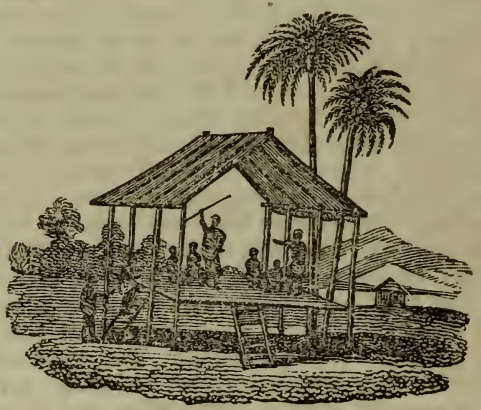

on posts fixed in the ground, and roofed with sloping planks, which leave the interior open to the air on every side. The houses and yards of persons in any degree opulent are enclosed by an outer wall or hedge, sometimes pretty high, serving the purposes both of privacy and defence. Even the palaces of the grandees, and of the greatest monarchs, consist of merely a cluster of these hovels or cottages, forming a little village, with large open spaces, and surrounded by a common wall. The state-hall of the sultan of the Fellatas, the greatest of the African princes, is an apartment to which, in Captain Clapperton's opinion, the term shed would in Europe be properly applied. Slender, however, as is the accommodation afforded by these edifices, they are liberally adorned, especially in the larger cities, both with carving and painting.

If African houses be of mean construction, the internal 
accommodations are equally scanty. Except the statechairs or thrones of the great monarchs, ascended only on very solemn occasions, there is not throughout native Africa a seat to sit upon. The people squat on the ground in circles; and if the chief can place beneath him the skin of a lion or leopard, he is at the height of his pomp. For a table there is at best a wooden board, whereon is neither plate, knife, fork, nor spoon; the fingers being supposed fully adequate to the performance of every function. If it be necessary to separate into parts a large joint, or even a sheep roasted whole, the dagger or sword of the warrior is drawn forth, and very speedily accomplishes the object.

The intellectual character of the natives of this continent presents a peculiar and remarkable deficiency. If we except the Ethiopic language, which is seemingly of Arabic origin, and the unknown characters, probably Phœnician, inscribed by the Tuaricks on their dark rocks, there is not a tincture of letters or of writing among all the aboriginal tribes of Africa. There is not a hieroglyphic or a symbol,-nothing corresponding to the painted stories of Mexico, or the knotted quipos of Peru. Oral communication forms the only channels by which thought can be transmitted from one country and one age to another. The lessons of time, the experience of ages, do not exist for the nations of this vast continent.

Notwithstanding so great a deficiency, the African must not be imagined as sunk in entire mental apathy. The enterprise of a perilous and changeful life developes energies which slumber amid the general body of the people in a civilized society. Their great public meetings and palavers exhibit a fluent and natural oratory, accompanied often with much good sense and shrewdness. Above all, the passion for poetry is nearly universal. As soon as the evening breeze begins to blow, the song resounds throughout all Africa, - it cheers the despondency of the wanderer through the desert,-it enlivens the social meeting, -it inspires the dance,-and even the lamentations of the mourner cre poured forth in measured accents. Their poetry does not consist in studied and regular pieces, such as, after previous study, are recited in our schools and theatres; they are extemporary and spontaneous effusions, in which the speaker gives 
utterance to his hopes and fears, his joys and sorrows. All the sovereigns are attended by crowds of singing men and singing women, who, whenever any interesting event occurs, celebrate it in songs, which they repeat aloud and in public. Flattery, of course, must be a standing reproach against this class of bards; yet from this imputation their European brethren are not exempted; while, from Major Laing's report, it appears that there is often present a sable Tyrtæus, who reproaches the apathy of the prince and people, and rouses them to deeds of valour. Specimens are wanting of the African muse ; yet, considering that its effusions are numerous, inspired by nature, and animated by national enthusiasm, they seem not unlikely to reward the care of a collector. The few examples actually given favour this conclusion. How few among our peasantry could have produced the pathetic and affecting lamentation which was uttered in the little Bambarra cottage over the distresses of Park! These songs, besides, handed down from father to son, contain evidently all that exists among these nations of traditional history. From the songs of the Jillimen of Soolimani, Major Laing was enabled to compile the annals of this small kingdom for more than a century.

In their religion, the negroes labour under the disadvantage of being left to unassisted reason, and that, too, very little enlightened. Man has, perhaps, an instinctive sentiment that his own fate and that of the universe are ruled by some supreme and invisible power; yet he sees this only through the medium of his wishes and imagination. $\mathrm{He}$ seeks for some object of veneration and means of protection, which may assume an outward and tangible shape. The negro reposes his faith in the doctrine of charms, which presents a substance stamped with a mystic and supernatural character, capable of being attached to himself individually, and of affording a feeling of security amid the many evils that environ him. The manitou of the native Americans is founded upon the same principle; and the similar use, by Catholics, of images, beads, and relics, pervertedly employed even under a pure and exalted religion, shows the strength of this propensity in the human mind. In all the Moorish borders, where writing is known, it forms the basis of feticherie; and its productions, rendered more brilliant and sensible by being enclosed in golden or orna- 
mented cases, are hung round the person as guardian influences. The very circumstance of the characters being unintelligible gives to them the power of exciting ideas more mysterious and supernatural. Where this art is unknown, a bow, a horn, a feather, the beaks and the claws of birds, even the most frivolous and insignificant object, is employed and relied on with the fullest confidence. Absurd, however, as are the observances of the negro, he is as stranger to the deadly bigotry of his Moslem neighbour. He neither persecutes, nor even brands as impious, those whose religious views differ the most widely from his own. There is only one point on which his faith assumes a savage character, and displays darker than inquisitorial horrors. The hope of an immortal destiny, dimly working in the blinded human heart, leads to the wildest errors. The despot, the object of boundless homage on earth, seeks to transport all his pomp, and the crowd of his attendants, to his place in the future world. His death must be celebrated by the corresponding sacrifice of a numerous band of slaves, of wives and of courtiers : their blood must water his grave; and the sword of the rude warrior, once drawn, does not readily stop; - a general massacre often takes place, and the capitals of these barbarian chiefs are seen to stream with blood. This horrid system is not exclusively African ; but it elsewhere exists on a smaller scale, and is attached to a state of society much more decidedly savage.

In regard to the social aspect of this continent, the unimproved condition in which it appears may be regarded as that perhaps in which violence and wrong have the widest field, and cause the most dreadful calamities to the human race. The original simplicity, founded on the absence of all objects calculated to excite turbulent desires and passions, has disappeared, while its place is not yet supplied by the restraints of law and the refinements of civilized society. War, the favourite pursuit, is therefore carried on with the most unrelenting fury ; and robbery, on a great and national scale, is generally prevalent. Brilliant and costly articles already exist; but these are distributed with an inequality which the needy warrior seeks by his sword to redress. African robbery is not perpetrated by concealed or proscribed ruffians, who shrink from the eye of man, and are the outcasts of social life. It is not even confined to the poor tribes of the Desert, who see caravans laden with immense wealth 
pass along their borders. Princes, kings, and the most distinguished warriors consider it a glory to place themselves at the head of an expedition urdertaken solely for the purposes of plunder.

Slavery seems also to belong to the barbarian state. Man has emerged from the limited wants of savage life. and sees productions of art, which he eagerly covets, without having acquired those habits of steady industry by which he might earn them for himself. His remedy is to compel those whom his superior strength, or any other advantage, enables him to bring under subjection, to labour in supplying his warts. Often the blind and spontaneous vereration of those tribes for their chiefs causes them to sink into voluntary slavery; many again are made captive in war ; and generally a great part of the population of every barbarous society is placed in a state of bondage.

From the two evils above described arises a third, still darker,-the stealing of human beings in order to make them slaves. This is perpetrated widely throughout $\Lambda$ frica, and attended with every circumstance of crime and horror. It is an enormity also in which the greatest sovereigns do not scruple to participate. Their troops surround a town in the dead of night, watching till the first dawn, when the gates are opened; - they then rush in, set fire to it, and while the victims, with shrieks and cries, are seeking to escape, bind and carry them off into slavery. It must be confessed, at the same time, that the unrelenting and atrocious spirit of this warfare has been in a great measure produced by foreign connexion, either with the European powers, or with Northern Africa, Turkey, and other Mohammedan states.

Notwithstanding so many evils, however, we may again repeat, that an unvaried cloud of moral darkness does not hang over Africa. The negro character appears to be distinguished by some features unusually amiable, by a peculiar warmth of the social affections, and by a close adherence to kindred ties. If some travellers have been illtreated and plundered, others have been relieved with the most signal and generous hospitality. The negro, unless when under the influence of some violent excitement, is, on the whole, more mild, hospitable, and liberal than the Moor; it is by the latter race that the atrocities against European travellers have been chiefly perpetrated.

In the political arrangements of the African states there 
occur some singular anomalies. A bold and independent spirit has been supposed to characterize man in a rude and uncivilized condition; and, accordingly, a number of petty communities here present an aristocratic, and sometimes even a republican form. But all the great kingdoms are subject to the most complete and abject despotism. Thousands of brave warriors bend down to one of their fellowmortals with a profound and servile abasement, never witnessed in polished or, as we call them, corrupted societies. Examples so frequent and striking have occurred in the course of this narrative, that we need not aduee any other illustration. It deserves particular notice that the nations in this degrading condition are the most numerous, the most powerful, and most advanced in all the arts and improvements of life; that, if we except the human sacrifices to which blind veneration prompts them, they display even a disposition more amiable, manners more dignified and polished, and moral conduct more correct, than prevail among the citizens of the small free states, who are usually idle, turbulent, quarrelsome, and licentious. Bad, therefore, as absolute power is in itself, there appears, nevertheless, in the disposition shown by man to submit to it in this uncultivated state, something salutary, and which even tends to his ultimate improvement.

The foreign races who have settled in Africa by migration and conquest are found fully established in the fine country along the Mediterranean. The inroad of the Arabs or Saracens, and the subsequent conquest by the sultans, have stamped completely their character on this vast region. The Turkish sabre and the Moslem creed lord it over these ancient seats of empire, light, and civilization. The remnants of the native tribes are either sunk in degradation, as the Copts, lurking in the recesses of the mountains, or wandering over desert plains, as the Brebers, the Tibboos, and the Tuaricks. The once-varied frame of society is now moulded into one gloomy monotony, such as is always produced by the influence of Mussulman habits. Turkish cities exhibit every where one uniform aspect; high walls of earth, without windows, border on narrow and dirty streets; and the nakedness and desolation of the exterior often form a striking contrast with the barbarian splendour within. A deep and grave solemnity, the absence of all gay and social 
meetings, and the entire seclusion of females, produce an effect wholly different from that of European society. In the country, the Arab population is simple and patriarchal; yet unhappily no strangers to violence and plunder in their very worst forms.

The two races, thus strikingly distinguished, native and foreign, Mohammedan and pagan, meet and mix in Central Africa, on the banks of the Niger, and on the other great rivers which water that region. Major Rennell considers the stream now named as the boundary between the Moors and negroes, as Pliny conceived it to separate the Africans from the Ethiopians; and the division, though not rigorously correct, is yet, in a general sense, conformable to fact. The Moors have made extensive conversions, and have introduced all that is known of letters or writing into the interior regions. Yet the lurid gleam thus shed over benighted Africa serves little more than to deepen the surrounding darkness. This sublime art is prized, not as the principal means of enlightening and enlarging the human mind, but as a tool of the magic art, - an instrument for manufacturing charms and fetiches, to be sold at high prices to the deluded natives. Only a few of the great sheiks and doctors read even the Koran. The most approved mode of imbibing its contents, as was formerly stated, is by tracing the characters on a smooth board with a black substance, then washing them off, and swallowing the water. Others, having enclosed the Koran in a large silver case, bear it constantly about, groaning under the burden, but expecting from it the greatest spiritual benefits.

Bigotry among these negro converts rises to a still higher pitch; and the future doom of the unbeliever is considered even more assured than on the shores of the Mediterranean. Meantime they subject him to the earthly miseries of foreign and distant bondage; for, while it is unlawful to enslave any true believer, the goods, the person, nay, the whole property of the Caffre are considered as rightfully belonging to the children of the prophet. This very circumstance causes a secret abatement in that eager spirit of proselytism which burns so fiercaly among the adherents of the Moslem creed. They cannot be insensible, that if the eyes of this host of unbelievers were enlightened, they themselves would forfeit the ground on which they rest their only claim, 
now in full exercise, of driving them by thousands to the markets of Kano and Tripoli.

In general we may observe, that while the Mohammedan converts in Central Africa are so intensely bigoted in respect to dogmas, they are more lax in practice than their brethren of Cairo and Tripoli. The females are not so closely immured; and the men seldom adhere to that precept of the Koran which enjoins abstinence from fermented liquors. The bouza, or acid beer, circulates briskly in Moslem as well as in pagan circles. It is true that the sovereigns, who are usually zealous Mussulmans, are occasionally seized with a paroxysm of zeal, and denounce dreadful penalties against all who indulge in this beloved liquor. But this proceeding, being extremely unpopular, causes only a transitory emotion, which soon subsides, and affairs resume their wonted course.

The Mohammedan religion, wherever it is established, has abolished the horrors of human sacrifice, - a great and important good. In all other respects, the introduction of this foreign race and foreign creed seems only to have deepened the evils under which Africa had formerly suffered.

Colonization, which in America has been carried to so vast an extent, filling that continent almost entirely with an European population, has never been attempted in Africa, except on the most limited scale. By much the largest colony is that founded by the Dutch at the Cape of Good Hope, which was transferred to the English by the events of the last war. In 1827, it was estimated to contain a population of 120,000 , being nearly double the amount in 1798 ; about 47,000 were Europeans, 28,000 Hottentots, and 35,000 slaves. Cape Town, which in 1824 comprised a population of 18,668 , has probably increased to upwards of 20,000 , and is now quite an English city, having newspapers, a "South African Journal" devoted to literature and science, and many intelligent inhabitants.

Ten years ago, under the severe pressure felt in Britain from the scarcity of employment and subsistence, several thousands were sent out to occupy the district of Albany in the eastern part of tire colony. This settlement has not been prosperous; and the expectation that it would prove a thriving agricultural station has, for the present, been dis- 
appointed. The severe droughts, and periodical inundations to which it is subject, have been found to render the raising of grain of every kind very precarious, and obliged the colonists to have recourse to pasturage; while the lots are too small to render the latter mode of industry sufficiently productive. They consist, according to Mr. Thompson, of only 100 acres, which are not capable of supporting above twelve oxen and cows. The Dutch settlers usually held 6000 acres, for which they paid merely the expenses of measursng and survey, amounting to between 300 and 600 dollars, with a quit-rent of from thirty to fifty. To obtain this quantity of land, the British settlers must carry out fiftynine servants (who it is true have their passage paid by government), depositing $10 l$. for each; which, with their support for three years, would exceed six times the value of the property. In 1825, after three unfavourable harvests, the distress of the colony became extreme, and a subscription of not less than $3000 l$. was raised in Cape T'own for their relief. A number then left the settlement; after which, the condition of those who remained gradually improved, and is now becoming comfortable. Mr. Thompson, however, recommends to emigrants who possess any capital to purchase land from the Dutch boors in the vicinity of the Cape; many of whom, possessing lots of nearly 100,000 acres, would willingly dispose of part of their grants for money.

To make head against the irruption of the Caffres, a body of military are stationed at the eastern boundary of the colony, who, in conjunction with the Albany settlers, have formed Graham's Town, the inhabitants of which amount to about 3000. Mr. Rose, who was lately there, describes it as " a large, ugly, ill-built, straggling place, containing a strange mixture of lounging officers, idle tradesmen, drunken soldiers, and still more drunken settlers." Its situation is romantic, being a deep hollow surrounded by high green hills, separated by glens overhung by steep and wooded precipices. These glens form the roads, which branch off like rays from a centre, and through them are seen labouring heavy wagons, drawn by oxen, frequently coming from very remote districts. They bring not only provisions and necessaries, but the rude products of the surrounding regions, $\rightarrow$ kins of the lion and leopard, horns of the buffalo, 
eggs and feathers of the ostrich, tusks of the elephant and hippopotamus, and rich fur mantles.

It would be improper to omit mentioning in this place the benevolent and persevering exertions of the Moravian and other missionaries, who, in that distant quarter of the continent, have made indefatigable exertions for the instruction and improvement of the miserable natives. They have not only communicated to them the light of true religion, but have successfully laboured to better their temporal circumstances, and communicate habits of order, cleanliness, and industry. The missionary stations now extend northward to Lattakoo, and eastward into the country of the Caffres; and they are daily assuming a wider range.

By far the most persevering attempt made by Britain to form a colony in Africa applies to that founded at Sierra Leone, originating in the most benevolent motives, and conducted under the patronage of highly distinguished characters. It had for its object the improvement of the continent, as well as the diminution and final abolition of the African slave-trade. In 1772 , a celebrated decision by Lord Mansfield established the principle, that a negro, from the moment he sets foot on British ground, becomes free. A strong interest was thus excited on the subject; and a great number of black servants having, in consequence of the above judgment, left their masters, were rambling in a somewhat desolate condition in the streets of the British metropolis. On learning their circumstances, Mr. Granville Sharp, an individual of unwearied benevolence, with the advice of Mr. Smeathman, who had spent a considerable time in Africa, formed the plan of transporting them into their native country, to lay the foundation of a colony. Government having concurred in the undertaking, the settlers were sent out in the Nautilus, Captain Thompson, and landed on the 9th May, 1787, upon a district of about twenty square miles, purchased from Naimbanna, the king of Sierra Leone. Unfortunately these negroes, as well as about sixty whites, chiefly females, sent along with them, were of mixed and very indifferent characters. A great proportion soon fell a sacrifice to the climate,- the others showed themselves destitute of all habits of industry, and were besides severely harassed by the hostility of the neigh bouring tribes ; 80 that, by the year 1791, the whole number 
was reduced to sixty-four. But the philanthropic zeal which prevailed in Britain for the colonization of Africa suffered no abatement. An association was formed under the titles of the St. George's Bay, and afterward of the Sierra Leone Company, with a capital of $250,000 l$., for the prosecution of this interesting object; and they soon found another quarter whence a supply of colonists might be drawn. During the American war, a number of negro slaves in the revolted colonies, on the invitation of the British government, had deserted their masters and joined her standard. After the unfortunate issue of the contest, these fugitives claimed the fulfilment of a promise said to have been made, that they should have lands allotted for their subsistence. The proffer now made of grants on their native shore, and in a more congenial climate, was cordially accepted. In March, 1792, they were landed at Sierra Leone, to the amount of 1131, in addition to 100 Europeans who had arrived in the preceding month. A fever, however, which the negroes had brought with them, aggravated by the unhealthy nature of the climate, carried off a considerable number; and to this latter cause of mortality half of the European settlers fell victims. The improvement of the colony was also much retarded by a very general spirit of insubordination; and, in 1794, it was barbarously plundered by a French squadron, which caused losses amounting to upwards of 50,000l. However, the settlement had gradually recovered, and was beginning to make some progress, when, in 1800 , it was recruited with 550 maroons, or insurrectionary negroes from Jamaica, who had been originally transported to Nova Scotia. They arrived at a very seasonable moment, when a disturbance had just broken out among the original body of negroes, which the British crews were busily employed in suppressing.

Notwithstanding all that had been done for the improvement of Sierra Leone, which had more than absorbed the original capital of the company, very little progress was yet made towards fulfilling its objects. No spirit of industry had been infused into the inhrabitants, and no amicable connexions forined with the neighbouring states. The company had scarcely the means of supporting it any longer; but there appeared reason to hope that the more energetic and influential efforts of government might vet 
overcome the obstacles which had hitherto baffled the most strenuous efforts of individuals. Accordingly, by mutual agreement, concluded on the 8th August, 1807, and carried into effect on the 1st January following, the settlement was surrendered into the hands of the crown, and placed on the same footing with the other British colonies.

From this time a new and much more copious source of population was opened. Since the year just mentioned, Britain had prohibited her own subjects from carrying on the slave-trade, and she had afterward obtained an assurance from other countries, that they would discontinue it along all the coast northward of the Line. She even received permission to treat as pirates such of their subjects as within those limits might be found employed in the conveyance of slaves. In her zeal for the abolition of this odious traffic, she has maintained a number of ships constantly watching those seas, and capturing every vessel thus unlawfully laden. The liberated negroes are brought to Sierra Leone, where they are located in the surrounding villages. For some time they receive rations, and are kept in pretty strict subordination; but, after a certain period, they obtain assignments of ground, from which to earn their own subsistence. On the 31st March, 1827, the slaves thus liberated amounted to 11,878 , of which there were 4701 males above and 1875 under fourteen ; $2717 \mathrm{fe-}$ males above and 1517 under that age ; besides 1068 settled in Freetown, or employed on the river in the timber trade. On the 31 st December, 1828, the number had been increased by new arrivals to 16,886 . Unfortunately, neither their progress in industry and civilization, nor the general prosperity of the colony, has answered the sanguine expectations once so fondly cherished. The efficiency of the government has been much impaired by various errors and unfortunate circumstances, and above all by the singularly deleterious influence of the climate on European constitutions. This, it is supposed, is owing not so much to the mere heat, as to the noxious exhalations arising from an ill-regulated town, and an uncultivated country, covered with such a mass of brush and jungle as to impede the necessary ventilation. The result is, a remittent fever, so malignant that almost all Europeans are attacked with it, and not one in three recovers. These circumstances have oftener than 
once led to the consideration whether Sierra Leone ought not to be entirely relinquished. An attempt has even been recently made to establish in its room a colony at Fernando $\mathrm{Po}$, a small island in the Gulf of Benin; but the expectations formed from its climate have also been entirely disappointed. Meantime, it is considered that the absolute abandonment of Sierra Leone would leave full scope for the contraband slave-trade, and frustrate all hopes of establishing a centre whence civilization might hereafter spread throughout Africa. The latest accounts from the governors, Colonel Denham, in 1827 and 1828, and Major Ricketts, in 1829, express a decided opinion that a spirit of improvement is at last beginning to be manifested,-that the inhabitants show a disposition to cultivate the ground, and an anxiety to be able to purchase European luxuries, - and that in the villages, particularly of Wellington and Waterloo, good churches, and a few stone houses, have been erected. The annual expenditure has been reduced to about $40,000 \mathrm{l}$, of which 17,000l. is for liberated Africans ; and government seems desirous to retain the settlement, till the natives shall be so far improved as to be able to conduct their own administration, and to afford an example of industry and order to the neighbouring states.

\section{- \\ CHAPTER XVII. \\ Geology of Africa.*}

Africa is distinguished from the other continents by its nearly insular form, being connected with Asia merely by an inconsiderable neck of land or isthmus, viz. that of Suez. It extends from the equator to about the average latitude of $35^{\circ}$ north, and also to the same degree of latitude south. The greatest length from north to south is from Cape Serrat in Algiers, in lat. $37^{\circ} 18^{\prime} \mathrm{N}$., to Cape

* According to some authors, the name Africa is derived from $a$, neg., and frigus, cold ; while others trace it from a small Carthaginian district, named Frigi-A-frike-a. 
Laguillas, in lat. $34^{\circ} 55^{\prime} \mathrm{S}$.; and the greatest breadth from Cape Verde, in long. $17^{\circ} 31^{\prime}$ W., to Cape Guardafui, in long. $51^{\circ} 15^{\prime} \mathrm{E}$. The northern portion of this continent is fully twice the size of the southern portion, and may be considered as about equal to South America; while the southern half is contracted to half the breadth of the northern part, and is nearly about the size of New-Holland. The shape of the corresponding coasts of Africa and America would induce us to infer that the two continents of Africa and America were once united,- the projecting or salient part of the former fitting exactly to the Gulf of Mexico; and the bulging part of South America, about Paraiba and Pernambuco, being about the size and shape to fill up the Gulf of Guinea. This great continent has but comparatively few gulfs, bays, arms of the sea, and promontories; and hence, notwithstanding its nearly insular form, its extent of coast is much less in proportion to its area, than in other quarters of the globe. The condition of man, the distribution of the lower animals and plants, even the climate of Africa, are intimately connected with this limited extent of coast.

On viewing Africa from its northern boundary on the shores of the Mediterranean, to its southern boundary at the Cape of Good Hope, the following natural divisions or regions present themselves to our attention :-

1. The northern region, formed by the Atlas range of mountains, hills, and plains, that extend from the coast of the Atlantic to the Gulf of the Syrtis, - and by the range of fertile hills and dales, and valleys mixed with deserts, in which are some insulated spots of verdure, known under the name oase, ${ }^{*}$ that extend from the termination of the Atlas to Egypt. $\dagger$

2. The eastern region, formed by Egypt, Abyssinia, Darfur, \&c.

* The word Oasis is Egyptian, and synonymous with Auasis and Hyasis (Strabo, 1xxiii. p. Alm. 1140). Abulfeda names the Oasis Al Wahat. In latter times the Cesars banished criminals to the Oases. They were sentenced to expiate their crimes on the islands of the Sandy Sea, as the Spaniards and English send their criminals to the Malouin islands and New-Holland. The latter could more easily escape by the ocean, than the former across the eurrounding deserts.

$\dagger$ The Atlas of Homer and Hesiod, according to Bory St. Vincent, is the Peak of Teneriffe; the Atlas of the Greek and Roman geographers, the African Atlas range of mountains. 
3. The Desert region, which is the flat, comparatively low tract of generally desert country, of which the principal portion is the Great Desert of Sahara, which lies between the 29th and 16th parallels, or about 780 miles in breadth, and extending across the continent from the Atlantic to the borders of Nubia.

4. The Region of Soudan, Nigritia, or the Country of the Negroes, extending in a belt across the continent as far as Abyssinia, and from the 16th to the 5th parallel, or about 600 miles in breadth. It is a rich and fertile region, yielding, with little labour, all the valuable productions of the tropical countries.

5. Great Table-land of Africa, or High Africa.-This, in all probability, very interesting part of Africa extends from the zone of Nigritia to the Cape of Good Hope. It appears to contain a lofty and extensive table-land, from which acclivities, supporting ranges of mountains, decline on the east and south towards the Indian Ocean; on the west to the Atlantic; and on the north to the Country of Soudan or Nigritia. Unfortunately the whole of this great region, with exception of the Cape of Good Hope and the Portuguese settlements on the east and west coasts, between which they are said to keep up a communication, is unknown to us ; so that there still remains a tract of country, at the least 30 degrees of latitude by 25 of longitude, or about 2,600,000 square geographical miles, of which nothing whatever is known. Now that the thirst for Arctic discovery has been quenched, and the public feeling has set strongly against expeditions to Central Africa, we trust that our government will be the first to engage in the exploration of the great table-land of Southern Africa.

Having premised this short account of the general features of Africa, we shall now state what is known of its geology and mineralogy, following in our account the great natural divisions already pointed out.

1. Geology of the Atlas, or Northern Region of Africa.*The northern division of Africa is principally characterized by the Atlas chain of mountain-ranges, on some of the loftiest points of which there is perpetual snow, which gives them a height of 12,000 to 13,000 feet above the level of

- The Egyptian, Abyssinian, and bondering African diseriots will be considered in orie of the succeeding volumes of this work. 
the sea. In it there are rocks of the primitive class, as granite, gneiss, mica-slate, and clay-slate. Copper and lead mines, said to occur in the primitive parts of the range, were worked by the ancients in Morocco and Algiers, but are at present neglected; and the same is also the case with the antimony and tin (?) said to have been discovered in these mountains. In Tunis, rock-crystals, graphite, or black-lead, and also iron and galena, are met with in the same kinds of rock. Although in extensive mountainranges the older rocks, or thase of the primitive class, generally predominate, such, according to travellers, is not the case with the Atlas, where the most extensive deposites are of a calcareous nature. This calcareous formation consists principally of secondary limestones, associated with deposites of sandstone. The limestone abounds with organic remains, as of shells, corals, and even fishes; and is said to be referable to the various limestones extending from the lias, or even the magnesian limestone, to chalk inclusive. Hence in this limestone-range there are magnesian limestones, oolite limestones, lias limestones, Jura limestones, and soft limestones resembling some kinds of chalk. Resting upon these limestones, or where they are wanting, as is the case at Algiers, there are deposites of tertiary rocks ; these are marly clays and limestones, with organic remains resembling those met with in the tertiary deposites on the north shore of the Mediterranean. Salt springs and gypsum are mentioned as eccurring in different parts of the range. These may be connected either with the secondary or tertiary, or with both classes of rocks.

Trap-rocks, of a modern date, also make their appearance among the rocks of the northern African zone. The most extensive display of these Plutonian masses is in the limestone in some districts to the south of Tripoli, where these rocks alter the position and change the characters of the limestone.

Age of the Atlas Mountains.-It is conjectured, by some geologists, that the great ranges of mountains of the earth have risen from below, through rents in previously existing strata, and not all at once, but at different times ; and further, that all mountain ranges having the same general direction have made their apperance from below at the 
same time. Thus the Pyrenees and Apennines, the mountains of Dalmatia and Croatia, and the Carpathians, which belong to the same system, - as may be deduced from the descriptions given of them by various geologists, - are all disposed parallel to an arc of a great circle, which passes through Natchez and the mouth of the Persian Gulf. Thus, whatever may have been the cause, the mountains in Europe, which have issued from the earth at the same period, form chains at the surface of the globe,-that is to say, longitudinal projections, all parallel to a certain circle of the sphere. If we suppose, as is natural, that this rule may be applicable beyond the limits within which it has been determined, the Alleghanies of North America,- - since their direction is also parallel to the great circle which joins Natchez and the Persian Gulf,-would seem to belong, in respect to date, to the Pyrenean system. Elie Beaumont has been able to verify the accuracy of this inference by a careful examination of the descriptions of American geologists. It would appear from this statement that we might venture to conclude that the mountains of Greece, the mountains situated to the north of the Euphrates, and the chain of Gates in India, which also come under this condition of parallelism already indicated, must have risen, like the Alleghanies, along with the Pyrenees and Apennines. If we apply this reasoning to the Atlas, which we find to have the same general direction as the Alps of Switzerland, from the Valais to Styria, and with that of the Caucasus, the Balkan Mountains, and the Himmaleh Mountains, we infer that these vast ranges, and also the Atlas, may have risen at the same period. But at what period did this elevation take place? This can be answered in a general way, by remarking, that in Switzerland the principal chain of the Alps appears to have upraised all the secondary, and also the tertiary strata; hence, according to the opinion already stated, these Swiss mountains, and consequently the Atlas and other ranges, already mentioned, may have risen from below at a comparatively recent period,-after the deposition of the tertiary rocks. Allowing this hypothesis to be plausible, it could be shown that an opinion of the ancients, - that, namely, which maintains that the whole country between the Syrtis and the 
Atlantic, over which the Atlas chain extends, was formerly insulated, and in that state formed the celebrated Atlantis, -is not destitute of geological probability.*

2. Geology of the Desert, or Sahara Region.-The second, or Sahara region, is eminently characterized by its vast desert of sand, the greatest and most frightful on the face of the earth. On the east it is bounded by a rocky limestone wall to the west of the Nile, and a series of oases and deserts extending from Darfur to the Libyan Besert : on the north by a range of oases and the flat and interesting country along the southern foot of the Atlas chain: on the west by the ocean : and, towards the south, it ceases in about $15^{\circ}$ N.lat., sloping gradually down to the fertile and well-watered country of Bornou on the east, Houssa in the centre, and the regions to the westward of Timbuctoo. Houssa and Bornou comprehend that region of Africa known by the name Soudan, or Land of the Blacks.

The Sahara may be considered as divided into an eastern and a western half. Its eastern and smaller halt is more varied by rocks, and cliffs, and oases, than the western and larger, which forms a vast sea of moving sand, well meriting the Arabian name, Sahara Bela-ma, or sea without water. The Western Sahara is bounded on the east in a line which passes through Fezzan, extending towards the south into Soudan, and towards the north to the Atlas. On many parts of the seacoast it extends under the sea, forming enormous sand banks; and along the coast there are extensive ranges of downs or sand hills. The coast is very dangerous, and much dreaded by seamen. Shipwrecks frequently take place, and the unfortunate survivors are carried off by the savages into a state of the most deplorable slavery. Cape Blanco, so well known to mariners, is not a rocky headland, but a flat sandy projecting white tongue of land, destitute of vegetation. The sand hills continue down to Cape Verde, - a promontory distinguished by its two lofty hills of sand, rising to a height of 600 feet, and overlooking the smaller surrounding downs, and forming a warning landmark, seen by sailors at a great distance.

* The particular geology of the Northern Region, which will include descriptions of Morocco. Fez, Algiers Tunis, and Tripoli, will appear in a future volume of this Library, the present volume being confined principally to the Central and Southern Regions of Africa. 
From the entrance of Gonzalo da Cintra, on the coast of Barbary, to Cape Verde, all the elevated points of solid rock are said to be of igneous origin: thus Cape Barbas, Cape Blanco, Cape Manuel, and Cape Verde are composed of basalt and lava. All the islands, too, along this west coast are of igneous origin.

In this vast waste there are a few oases and wadeys, or valleys, in which springs of water are found, and shrubby plants, chiefly acacias, and tufts of grass. It is inhabited only by pastoral tribes, who roam about from one oasis to another, where a little verdure may be found. Some of these tribes add to their scanty means of subsistence the plunder of such feeble caravans as they may venture to attack; and others are employed in collecting salt and natron for the markets of Bornou and Soudan. For hundreds of miles not an oasis is seen, the surface being one continued plain; in some places blown up into high ridges, in others presenting undulations like the waves of the sea. In parts of the Desert, insulated hills, or ridges of hills of naked sandstone, sometimes also of granite, rise through the sandy surface, appearing like so many islands in the ocean.

Account of the Line of Desert from Tripoli to the Lake Tchad. - The line of desert, extending from Tripoli by Mourzouk to Kouka, has been described by our former pupil the late excellent and intelligent traveller Dr. Oudney, and by his enterprising fellow-travellers Clapperton and Denham. As the account is novel and interesting, we shall now lay some details illustrative of it before our readers; occasionally, also, referring to the observations of another well-known African traveller, Captain Lyon.*

Subterranean Villages.-All around Tripoli the prevailing rocks are of limestone,-partly of secondary, partly, it is said, of tertiary formation. The Arab inhabitants of the Gharian limestone mountains in Tripoli live under ground, - a circumstance worthy of being particularly recorded, on account of its connexion with the ancient history of man,

* To those interested in Africals adventuro, we recommend an interesting little volume just published, entitled, "A Biographical Memoir of the late Dr. Walter Oudney and Captain Hugh Clapperton, both of the rnyal navy, and Major Alexander Gordon Laing, all of whom died amid their active and enterprising endeavnurs to explore the interior of Africa. By the Rev. Thomas Nelson, Member of the Wernerian Society, \& $c$ " $12 \mathrm{mo}$. Edinburgh, 1830, by Waugh and Innes. 
and also his present condition in some countries. Captain Lyon says,- "We stopped at a nest, I cannot call it a village, where all the habitations are under ground. The sheik, on hearing we were under the protection of the bashaw, came to welcome us, and gave us the only hut the place afforded, in which we placed our people and camelloads. As for ourselves, we preferred clearing part of the farm-yard, and pitching our tent in it, surrounded by our horses and camels. This place is called Beni-Abbās. As the natives live, as I have observed, under ground, a person unacquainted with the circumstance might cross the mountain without once suspecting that it was inhabited. All the dwelling-places bein $r$ formed in the same manner, a description of the sheik's may suffice for the rest. The upper soil is sandy earth, of about four feet in depth; under this sand, and in some places limestone, a large hole is dug, to the depth of twenty-five or thirty feet, and its breadth in every direction is about the same, being, as nearly as can be, a perfect square. The rock is then smoothed so as to form perpendicular sides to this space, in which doors are cut through, and arched chambers excavated, so as to-receive their light from the doors. The rooms are sometimes three or four of a side; in others, a whole side composes one,- - the arrangements depending on the number of inhabitants. In the open court is generally a well, water being found at ten or twelve feet below the base of the square. The entrance to the house is at about thirty-six yards from the pit, and opens above ground. It is arched overhead, is generally cut in a winding direction, and is perfectly dark. Some of these passages are sufficiently large to admit a loaded camel. The entrance has a strong: wall built over it, something resembling an ice-house. This is covered overhead, and has a very strong heavy door, which is shut at night, or in cases of danger. At about ten yards from the bottom is another door, equally strong; so that it is impossible to enter these houses should the inhabitants determine to resist. Few Arab attacks last long enough to end in a siege. All their sheep and poultry being confined in the house at night, the bashaw's army, when here, had recourse to suffocating the inmates, being unable to starve them out." Again, at page 29, he says,- "At noon, we arrived at a cluster of 
nests about six miles from Beni-Abbās : all the habitations of this place are of the same kind as those already described."

Cotonel Silvertop, in an interesting memoir on the Lacustrine Basins of Baza and Alhama, in the New Edinburgh Philosophical Journal, vol. ix., gives an account of a subterranean village called Benamaurel, in Granada in Spain, which is on a larger scale than those mentioned by Captain Lyon. It would probably be a difficult antiquarian investigation to trace the origin of these Spanish subterranean dwellings, inhabited by a considerable population of the poorer classes in various parts of the province of Granada. They may be observed in the outskirts of the cities of Granada, Guadiz, and Baza; but are most numerous in the villages of Benamaurel, Castillejos, Caniles, and Cullar, where they have been excavated in the marl strata, so extensively deposited in that basin, and in those of Benabra, and another in the valley of Guadiz. In Benabra, the entire population lives in caves,-the church, the curate's house, and the venta being the only edifices seen above ground. In the neighbourhood of Bagnovea, in the pope's territories, there is a village, of which an Italian traveller has observed, that a few stones for the purpose of closing the entrance of the cavern, a hole for the smoke to go out of, and an aperture to admit the light, suffice to complete each habitation. In the Isle of Ponza, near the Bay of Naples, is another town of the same description, the inhabitants preferring to reside in caves, although the island abounds in good building materials. In France, many villages of inhabited caverns still exist. Swinburne describes a village of the same kind, which occurs in the province of Andalusia in Spain. The natives of New-Holland and other countries still shelter themselves in caves and caverns, and in the hollows of trees. At an early period, the inhabitants of Europe appear also to have lived principally in natural caves and caverns, or in such as they dug in soft rocks.

The subject of caves has recently attracted considerable attention; but more on the part of the geologist than of the antiquarian. It has been ascertained that in caves in the south of France human remains had been found along with bones of quadrupeds, now no longer met with in a living 
state, either in Europe or elsewhere. The destruction of the forests in which they found shelter, the drying up of the lakes, on the borders of which they found their food, and partial convulsions of nature, sufficiently account, says Dr. Hibbert, for their extinction. In this view, the investigation of the caves in which human bones are found is as much the province of the antiquary as of the geologist. The same geologist assumes as an hypothesis, that the tribes inhabiting Europe, previous to the historical times, were in a state similar to that of the Fins described by Tacitus, - as leading an almost brutish life, destitute even of the earliest rudiments of the arts. Such beings might well be conceived to contend with the beasts, above whom they were so little elevated, for places of shelter they knew not how to construct; or, at all events, they might crawl like the beasts, or the New-Hollanders, into caves or caverns to conceal their dying agonies. At this period the bones could scarcely have been deposited in caves for the purpose of inhumation, the idea of sepulture belonging to a more advanced state. The rude fragments of earthenware found in the same caves belonged to an extremely rude and very early period. The Celtic and Gothic tribes, who supplanted the aborigines of Europe, seemed to have reached the agricultural state. The Germans are described as inhabiting houses built of gross and unhewn materials, constructed without the aid of mortar; and also caves, into which they retired for shelter from the inclemency of the winter, as do the inhabitants of some countries in Northern Asia at present. Traces of these ancient subterraneous habitations are still to be met with in Germany, but much more frequently in France and Italy, where the nature of the rock is more favourable to the task of excavation, and they are most numerous in the south of France. Each cave appears to have been entered by a low chink or fissure, situated almost half way between the floor of the cave and its roof, and differing as little as possible from the level of the avenue by which it was approached. Sometimes the eaves are isolated, sometimes they are found in groups. These caves continued to be used even during the feudal period, as could be proved by descriptions of caves met With in different parts of Europe, particularly in the south of France.

We recommend to the particular attention of travellers 
the examination of caves and caverns, being an investigation, as appears from the preceding details, not only intimately connected with the early history of man, and of his condition in a low state of civilization even at the present day, but also with the geological history of our species, and of that of several of the more powerful and interesting species of the class of quadrupeds.

In the route from Tripoli to Mourzouk, the first change of rock met with by Dr. Oudney was at Benioleed,* where he remarks there is a rich valley, the sides of which are of limestone hills 400 feet high, capped with greenstone and amygdaloid. The Jibel Gulat, 600 feet high, one of the highest hills he had met with since leaving Tripoli, is considerably to the south of Benioleed. It is composed of marls and limestones, containing fossil oysters and limpets, forming a deposite which is said to resemble the tertiary rock named calcaire grossière of the Paris basin, which occurs in Malta, Sicily, and on the norih side of the Mediterranean, on the shores of Italy and.France. These limestones continue onwards to the valley of Bomjem, $t$ which was found strewed with gypsum. Captain Lyon mentions gunflints as occurring in the road to Bonjem; while Dr. Oudney speaks of striped jaspers and cornelians, but does not mention gun-flints. These rocks continue onwards to Sockna. A short distance to the south of Sockna are the Soudah or Black Mountains. These, Captain Lyon says, rise to a height of 1500 feet, extend about 100 miles in breadth from N. to $S$., and as far as the eye can reach from E. to W. They are perfectly barren, of 1 very irregular forms, occasionally broken into detached masses, and sometimes rising into cones. They are composed of trap-rocks, said to be of the nature of basalt. After crossing this range, the route to Mourzouk leads across gravelly and sandy tracts, with frequent appearances of dolomite limestone, occasionally rolled masses of basalt, and agates, probably derived from amygdaloidal trap $\neq$ The road from

* The inhabitants of Benioleed are Arabs: The water is excellent, but some of the wells are 100 feet deep.-Lron.

$\dagger$ This is the northern boundary of the kingdom of Fezzan. There are here some perfect remains of a Roman foriress, built by order of Septimius Severus.-Lxon.

$\ddagger$ At Sebha, a town of 800 inhabitants, the population is no longer Arab. but black; hence Captain Lynn, in his may, says, "Sebha, N, lat. erio biack population conmences." 
Mourzouk, which our travellers left on the 29th of November, 1822, to Traghan, the former capital of Fezzan, presented frequent incrustations of salt. From Traghan to Maefen, the road lies over a mixture of clay and salt. The path, by which all the animals move for several miles, is a narrow space or stripe worn smooth, bearing a resemblance, both in hardness and appearance, to ice. Near Maefen, it assumes a new and more beautiful shape, being traversed by numerous fissures, from the sides of which, and from the roofs of cavities several feet deep, beautiful crystals of salt were observed shooting. The road extends more than twenty miles east and west. The water of Maefen, although impregnated with soda, is not disagreeable to the taste, or unwholesome. The continuation of the journey from Maefen to Gatrone, which occupied two days, was across the sand of the desert, which, it is said, was beautifully fine, round, and red.* This place is surrounded by sand hills and mounds of earth, covered with a tree called athali. Though encamped on the south side of the town, they had cold north and north-west winds ; and the temperature in the tent was from $43^{\circ}$ to $45^{\circ}$ in the mornings. On the 9th December reached Tegerhy. $t$ This place they found pleasantly situated. On the 13th left Tegerhy, and proceeded on the Desert : it was scattered with mounds of earth and sand, covered with various shrubs, which were greedily devoured by the camels. On the 16th reached Ghad. On the 17th continued their journey over a stony plain, without the least appearance of vegetation. The exposed rocks were sandstones of different kinds, red and black; fine specimens of petrified wood were found, in which were observed, in the centre, sap-vessels, and knots filled with calcareous matter, the woody fibre charged with a siliceous substance; beautiful rays were observed shooting from the centre to the circumference. The depth of a well they met with, named Meshroo, was from 15 to 20 feet; the water good, and therefore free from saline impregnations: the ground around it was strewed with human skeletons of the slaves who had arrived, exhausted with thirst and fatigue. "The horrid consequences of the slave-trade," says Dr. Oudney, "were strongly

* Caprain Lyon mentions gypsum and selenite as occurring in this quarter.

t This is the southernmost town in Fezzan. 
brought to our mind; and, although its horrors are not equal to those of the European trade, still they are sufficient to call up every sympathy, and rouse up every spark of humanity. They are dragged over deserts ; water often fails, and also provisions scantily provided for the long and dreary journey. The Moors ascribe the numbers destroyed to the cruelty of the Tibboo traders : there is, perhaps, ton much truth in this accusation. Every few miles a skeleton was seen through the whole day; some were partially covered with sand, others with only a small mound formed by the wind; one hand often lay under the head, and frequently both, as if in the act of compressing the head; the skin and membranous substance all shrivel up and dry, from the state of the air. The thick muscular and internal parts only decay." Ranges of hills were seen to the south and east. In the evening the party halted near a well, within half a mile of Meshroo. Around this spot were lying more than one hundred human skeletons, some of them with the skin still remaining attached to the bones, - not even a little sand thrown over then. The Arabs were amused at the horror expressed by the travellers at this sight, and said, they were only blacks; and began knocking about the limbs with the butt-end of their firelocks. "Our camels," says Denham, "did not come up until it was quite dark, and we bivouacked in the midst of these unearthed remains of the victims of persecution and avarice, after a long day's journey of twenty-six miles, in the course of which one of our party counted 107 of these skeletons." They continued journeying until the 21st, partly through sand and among sandstone hills, some of which were 600 feet high. On the $22 \mathrm{~d}$, they moved before daylight, passing some rough sand hills mixed with red sandstone, to the west, over a plain of fine gravel, and halted at the matten called El Hammar, close under a bluff-head, which had been in view since quitting their resting-place in the morning. During the last two days they had passed, on an average, from sixty to eighty or ninety human skeletons each day ; but the numbers that lay about the wells at El Hammar were countless; those of two women, whose perfect and regular teeth bespoke them young, were particularly shocking; their arms still remained clasped round each other as they had expired, although the flesh had long since perished by being exposed 
to the burning rays of the sun, and the blackened bones only left ; the nails of the fingers, and some of the sinews of the hand, also remained; and part of the tongue of one of them still appeared through the teeth. They had now passed six days of desert without the slightest appearance of vegetation. On the following (24th) day, they had alternate plains of loose sand and gravel, and a distant view of some hills to the west. "While," says Denham, "I was dozing on my horse about noon, overcome by the heat of the sun, which at that time of the day always shone with great power, I was suddenly awakened by a crashing under his feet, which startled me excessively. I found that my steed had stepped upon the perfect skeletons of two human beings, cracking their brittle bones under his feet, and, by one trip of his foot, separating a scull from the trunk, which rolled on like a ball before him. This incident gave me a sensation which it took some time to remove."

On the following day, 24th, the plain was observed covered with slight irregularities, and strewed with pieces of variously-coloured calcareous spar and selenite, and thick beds of gypsum were noticed. Halted in the evening at wells situated under a ridge of low white hills of sandstone, called Mafrasben-Kasaretta, where there are also beds and hills of limestone. The whole of the journey this day, 25th, was through hills of a rather bold and picturesque character, of dark-coloured sandstone. One day's journey was also through a tract partly plain, partly of sandstone hills, to a wadey named Izhya. Here the travellers had a gale of wind for three days; their tents were nearly buried with sand, and were obliged to roll themselves up in blankets nearly the whole time. They started again on the 30 th, and on the evening of the 31 st halted under some low brown sandstone hills. The journey from 1 st January to the 6th was partly along and across a ridge of sandstone hills, in no place more than 400 feet high. On the 6 th they halted at Tiggema, which is one of the highest points of the sandstone range, about 400 feet high, and hangs over the mud houses of the town. Its sides are nearly perpendicular, and it is detached from the other hills by a chasm. On the 8 th, the route still under the range of sandstone hills, they passed a salt lake, and farther east, at Dirkee, two natron lakes. In the centre of each of these lakes is a solid body 
or island of natron. In one lake the island is 15 feet high, and 100 feet in circumference. The natron is associated with muriate of soda, or common salt. On the 12 th they reached Bilma, after passing through a wadey the greater part of the way, which exhibited many patches of saline incrustations, also beds of red sandstone, containing numerous nodules of iron ore. The sandstone hills exhibit, on their summits, forms resembling ruins of towns and castles. Near to Bilma are several salt lakes that afford very pure and wellcrystallized salt.* About a mile from Bilma is a spring of beautiful clear water, which rises to the surface of the earth, and waters a space of two or three hundred yards in circumference, which is covered with fresh grass ; but, passing this, the traveller must bid adieu to every appearance of vegetable production, and enter on a desert. From Bil. ma, which was left on 16 th January, the route led over loose hills of fine sand, in which the camels sunk nearly kneedeep. In passing the desert wilds, where hills disappear in a single night by the drifting of the sand, and where all traces of the pussage, even of a large kafila, sometimes vanish in a few hours, the Tibboos have certain points in the dark sandstone ridges which from time to time raise their heads in the midst of this ocean of sand, and form the only variety, and by them they steer their course. They halted in the evening at Kaflorum, which is a nest of hills of coarse dark sandstone. On the 17th bivouacked under a head called Zow (difficult), to the east of which were found several wells. "This day, the 18 th," says Denham, "the sand hills were less high, but the animals sunk so deep that it was a tedious day for all. Four camels of Boo Khalloom's gave in; two were killed by the Arabs, and two were left to the chance of coming up before morning. Tremendously dreary are these marches; as far as the eye can reach, billows of sand bound the prospect. On seeing the solitary foot-passenger of the kafila, with his water-flask in

* Captain Lyon says,-- "I found no one who knew of the salt lakes of Domboo laid down in all the maps; but there is abundance of salt at Agram (which is four days' journey from Bilma, W.S.W.), and a large lake, on the borders of which this article is collected. The Tuaricks go there and carry away great quantities to Soudan. This agrees with the accounts of Domboo; and, from the circumstance of Tuaricks going to Agram, and the position of that place, I am led to imagine it may be the same Domboo, though under a different appellation." 
his hand and bag of zumeeta on his head, sink at a distance beneath the slope of one of these, as he plods his way alone, hoping to gain a few paces in his long day's work by not following the track of the camels, one trembles for his safety: the obstacle passed which concealed him from the view, the eye is strained towards the spot, in order to be assured that he has not been buried quick in the treacherous overwhelming sand." On the 20th, passed hills named Geisgal, of dark sandstone, and a table-shaped hill in the wadey Dibla, of sandstone and slate-clay. Here some fulgurites, or lightning-tubes, were observed in the sand. A number of - semi-vitrified small stones were found on the sands, which the people collected to use as bullets. The journey still across sandy deserts to an extensive wadey called Aghadem, which they reached on the 23d. Here are several wells of excellent water, and hills of sandstone. From thence crossed the sand desert of Tintuma. On the 27th, "we," says Denham, "appeared gradually approaching șomething like vegetation. We had rising sands and clumps of fine grass the whole way, and the country was not unlike some of our heaths in England." Towards evening the trees increased in number; and when the travellers halted, the animals found abundance of food. The spot where they halted is called Geogo Balwy. They continuel their route across sands and through valleys, bounded by low sandstone hills, and by some salt lakes. As they approached the great fresh-water lake Tchad, the country improved much in appearance, owing to the increase of soil, and consequently of vegetation. On the 4th February, they came in sight of this great lake. On February 5th, reached Lari, on the shore of the Great Lake. On the 6th, the freed slaves, natives of Kanem, left them for their homes, three days' journey to the eastward. One poor deaf and dumb woman, whom the rapacity of Mukni, the former sultan of Fezzan, who spared neither age, sex, nor infirmity, had induced him to march to Tripoli, had shed torrents of. tears ever since she had been made acquainted, by signs, that she was to go to Bornou. She had left two children behind her, and the third, which was in her arms when she - was taken by the Arabs, had been torn from her breast after the first ten days of her journey across the Desert, in order that she might keep up with the camels. Her expres- 
sive motions, says Denham, in describing the manner in which the child was forced from her and thrown on the sand, where it was left to perish, while whips were applied to her, lame and worn out as she was, to quicken her tottering steps, were intensely affecting. After travelling through a wooded and beautiful country, they, on February 17th, reached Kouka. This was to the travellers an important day, as they were now about to become acquainted with a people who had never seen, or scarcely heard of an European.

In a journey which was' undertaken to Mandara, the whole country to Affagay was found to be alluvial. Denham crossed part of a great range of mountains, named the Mandara hills, at the most southern limit of this journey. He says, "On all sides the apparently interminable chain of hills closed upon our view in rugged magnificence and gigantic grandeur, though not to be compared with the higher Alps, the Apennines, or even the Sierra Morena, in magnitude; yet by none of these were they surpassed in picturesque effect." This range of mountains was found to contain granite, mica-slate, hornblende rock, and ores of iron. There were observed on the southward lower ranges of newer formation, consisting of conglomerated rocks abounding in fossil oyster-shells.

On what Formation does the Sand of the Desert rest?-It is a question with geologists, on what formation or formations does the sand of the Desert rest? We have not data sufficient for a very satisfactory answer to this question. Judging, however, from the details of travellers, we would infer that the predominating formations are of the secondary class of rocks. The secondary formations met with are, red and variegated sandstone, with gypsum and salt, and white and gray sandstone sometimes disposed in fantastic forms. The salt in some places is seen in thick beds, along with red or variegated sandstones. Limestones of various lescriptions, that appear to belong to the Jura limestone formation, are met with. Besides those already enumerated, there occur other limestones, clays, and gypsums, belonging to the tertiary class, from which salt springs issue. But not only these softer rocks appeared rising through the sands of the Desert; also harder rocks, as greenstone, amygdaloid, and granite, in some places project, 
aithough rarely in isolated rocks, ridges, and cliffs. From these details it appears that the general basis of the Desert comsists of secondary rocks, principally sandstone and limestone.

Description of a Trona or Natron Lake.-Natron or trona, as already mentioned, is found in various parts of the Desert, but principally in its eastern half. Dr. Oudney describes, in the following terms, in a letter to us, afterward.printed in Denham's Travels, the wadey Trona he passed through in his journey from Tripoli to Mourzouk:- "Monday, July 8. - We entered the wadey Trona early this morning, on the north-east side. Near where we entered there are a cluster of date palms, and a small lake, from which impure trona is obtained. On the western side the trona lake is surrounded with date-trees, and its marshy borders are covered on almost all sides by grass and a tall juncas. It is about half a mile long, and nearly 200 yards wide. At present it is of inconsiderable depth, from the evaporation of the water; for many places are dry now, which are covered in the winter and spring. The trona crystallizes at the bottom of the lake when the water is sufficiently saturated; for when the water is in large quantities it eats the trona, as the people say. The cakes vary in thickness from a fine film to several inches (two or three). The thickest at present is not more than three-fourths of an inch; but in the winter, when the water begins to increase, it is of the thickness I have mentioned. The surface next the ground is not unequal from crystallization, but rough to the feel from numerous small rounded asperities. That next the water is generally found studded with numerous small, beantiful cubical crystals of muriate of soda; the line of junction is always distinct, and the one is easily removed from the other. When not covered with muriate of soda, the upper surface shows a congeries of small tabular pieces joined in every direction. When the mass is broken, there is a fine display of reticular crystals, often finely radiated. The surface of the water is covered in many places with large thin sheets of salt, giving the whole the appearance of a lake partially frozen over; film after film forms till the whole becomes of great thickness. Thus may be chserved, on the same space, trona and cubical 
crvstals of muriate of soda: and. on the surface of the water, films accumulating till the whole amounts to a considerable thickness. The soil of the lake is dark-brown muddy sand, approaching to black, of a viscid consistence and slimy feel ; and, on the lately uncovered surface. of the banks, a black substance, something like mineral tar, is seen oozing out. The water begins to increase in winter, and is at its height in the spring. In the beginning of the winter the trona is thickest and best ; but in the spring it disappears entirely. The size of the lake has diminished considerably within the last nine years, and, if care be not taken, the diminution will be still more considerable; for plants are making rapid encroachments, and very shallow banks are observable in many places. On making inquiry, I found the quantity of trona has not sensibly diminished for the last ten years. Perhaps it may appear so, from there always being sufficient to answer every demand. The quantity annually carried away amounts to between 400 and 500 camel-loads, each amounting to about 4 cwit.,-a large quantity, when the size of the lake is taken into account. It is only removed, from the lake when a demand comes. A man goes in, breaks it off in large pieces, and those on the banks remove the extraneous matter, and pack it in large square bundles. The water in the valley is good, being free from saline impregnatiơn."-Clapperton, Denham, and Oudney's Journal, p. 57.

Fulgurite and Meteoric Iron found in the Desert.-In some parts of the Desert, tubes of sand, resembling those found at Drigg, in Cumberland, and in different sandy districts on the continent of Europe, are met with. They are named fulgurites, or lightning-tubes, by naturalists, and are supposed to be formed by the lightning striking through the sand, and partially melting portions of it. Masses of meteoric iron also have been met with in the Desert. Golberry, in his journey through Western Africa, in the years 1805-7, mentions his having found a mass of meteoric iron in the Desert. Fragments of it were brought to Europe by Colonel O'Hara, and were analyzed by Mr. Howard, who found it composed of ninety-six parts of iron and four of nickel.

Observations on the Sand of the Desert.-Having now 
roticed the rocks and some of the minerals met with in the Desert, we shall next attend to the sand of which it is principally compased. The loose alluvial matter which forms the sand of the Desert is principally composed of particles of white and gray quartz of various sizes, generally very small, forming the sand, properly so called, seldom so large as to form gravel and pebbles. Some are of opinion that this sand is an original deposite ; others, that it is formed from previously existing rocks through the agency of water.

Moving Pillars of Sand in the Desert.-During the storms that often rage in this Desert, the sand is raised into clouds that obscure the horizon, or it is by whirlwinds raised into pillars. Bruce describes an appearance of this kind, which he witnessed in his journey through the eastern part of the Desert, in his route to Abyssinia, in the following terms : - "At one o'clock we alighted among some acacia-trees at Waadi-el-Halboub, having gone twenty-one miles. We were here at once surprised and terrified by a sight, surely one of the most magnificent in the world. In that vast expanse of Desert, from west to north-west of us, we saw a number of prodigious pillars of sand at different distances, at times moving with great velocity, at others stalking on with majestic slowness. At intervals we thought they were coming in a very few minutes to overwhelm us, and small quantities of sand did actualiy more than once reach us; again they would retreat, so as to be almost out of sight, their tops reaching the very clouds ; then the tops often separated from the bodies, and these, once disjoined, dispersed in air, and did not appear more ; sometimes they were broken in the middle, as if they were struck with large cannonshot. At noon they began to advance with considerable swiftness upon us, - the wind being very strong at north. Eleven ranged alongside of us, about the distance of three miles ; the greatest diameter of the largest appeared to me at that distance as if it would measure ten feet. They retired from us with a wind at south-east, leaving an impression on my mind to which I can give no name, though surely one ingredient in it was fear, with a considerable deal of wonder and astonishment. It was in vain to think of flying; the swiftest horse would be of no 
use to carry us out of this danger, and the full conviction of this riveted me to the spot." A similar account of these moving pillars of sand is given by M. Adanson, who had an opportunity of observing one of them crossing the river Gambia from the Great Desert. It passed within eighteen or twenty fathoms of the stern of the vessel, and seemed to measure ten or twelve feet in circumference, and about 250 feet in height. Its heat was sensibly felt at the distance of 100 feet, and it left a strong smell, more like that given out by saltpetre than sulphur, and which remained a long time.

Sand-wind.-The overpowering effects of a sudden sand-wind, when nearly at the border of the Desert, often destroy a whole kafila, already weakened by fatigue. "Indeed," says Denham, "the sand-storm we had the misfortune to encounter in crossing the Desert gave us a, pretty correct idea of the dreaded effects of these hurricanes. The wind raised the fine sand, with which the extensive Desert was covered, so as to fill the atmosphere, and render the immense space before us impenetrable to the eye beyond a few yards. The sun and clouds were entirely obscured, and a suffocating and oppressive weight accompanied the flakes and masses of sand which, I had almost said, we had to penetrate at every step. At times we completely lost sight of the camels, though only a few yards before us. The horses hung their tongues out of their mouths, and refused to face the clouds of sand. A parching thirst oppressed us, which nothing alleviated."

How the prevailing Winds affect the Sand of the Desert. -The prevailing winds in the Sahara are the easterly and westerly, - the first blows nine months, the second but three months. This circumstance is intimately connected with the motions and distribution of the sand of the Desert. In the eastern half of the Sahara the sind is more gravelly, and the general cover of sand shallower than in the western half; so that; in travelling towards the west, the depth of the sand and the completeness of the sandy covers increases. This distribution of the sand is probably owing to the easterly wind, which blows so much longer than the westerly, carrying the sand before it from the East Sahara. To the same cause we may refer the less frequent appearance of rocks, the gradual diminution in magnitude and of 
frequency of oases, even their total destruction by blowing Gand as we advance westward.*

What is the Geognostical Age of the Sahara?-Many are of opinion that the Sahara must at one time have been the bed of the ocean. The very frequent saline impregnation of the sand, the rolled pebble and sands mixed with seashells at the foot of the southerri acclivity of the Atlas and other parts of the Desert, are considered as in favour of this hypothesis. At what period did this great tract rise above the waves of the ocean? This can only be guessed at by an attentive examination of the junctions of the sandstones, limestones, \&c. with the bounding primary ranges of the Desert. If they are the same on the south side as on the north or Atlas side, then it would follow that the Desert rose above the sea at the time when the Atlas made its appearance from below; that is, after the deposition of the tertiary. rocks, - at a period when the earth and its animals and vegetables were nearly the same as at present.

3. Geology of the Region to the South of the Sahara, and. to the North of the Great Table-land.-This is the Land of the Negroes, called also Soudan or Nigritia. The high land on the west of this part of Africa is partly accumulated around the sources of the rivers Senegal, Gambia; Rio Grande, and Niger or Joliba. From the sources of the Niger the mountains run eastwards, under the name Kong Mountains, across Africa, when at length they are said to form a junction with the Mountains of the Moon, that range onward and join with the vast alpine land of Abyssinia. Parts of this boundary are very lofty, some mountains of the Kong chain attaining an elevation of 14,000 feet above the level of the sea. From the meager details of travellers in regard to this part of Africa, all we can infer is, that the mountains on the west and along the south of this zone contain primitive rocks of various descriptions, as granite, mica-slate, clay-slate, quartz rock, hornblende rock, limestone, \&c. In different parts these rocks seem traversed by augite greenstone or secondary traps. The secondary sandstones and limestones connected with these ranges not having been accurately described, we cannot venture any

* The long continuance of the easterly in comparison of the westerly wind, fnay explain how it happens that the whole country of Egypt has thet ere this been swallowed up by the sand-flood of the Desert. 
conjecture as to their geological nature. At Gambia there is only sand; but opposite the town there are islands of red decomposed granite. At Goree the rock is a fine basalt, which takes a regular prismatic form, similar to the Giants' Causeway.*

Vast tracts of flat country, partly rich and cultivated, partly desert and sandy, extend to the eastern limit, including Soudan, of which the great kingdoms are Houssa. and Bornou. In the flat and desert regions, salt lakes and natron lakes, and salt and natron springs, are met with. Beds of rock-salt occur in different places, as at Teleg, north of Timbuctoo, half a day's journey from Taudeny. From this place is exported all the salt from Timbuctoo to Jenne, and from that town to Soudan. The salt is there disposed in beds several feet thick : it is mined into large slabs, which are afterward sawn into blocks for the market. These mines form the riches of the country.

African Gold.-'This continent, as is well known, affords a considerable quantity of gold, which is found in the form of rolled pieces, or in minute grains, named gold dust, in the alluvium of rivers, lakes, valleys, and the wide-spreading sand of the vast Desert. The northern parts of Africa afford but little gold; while in the countries to the south of the Great Desert, there are tracts remarkable for the quantity of gold they contain. 'Thus the flat country, which extends from the foot of the mountains in which are situated the sources of the Gambia, Senegal, and Niger, has, from an early period, afforded gold. Bambouk, which is situated to the north-west of these mountains, furnishes the greatest part of the gold which is sold on the western coast of Africa, as well as that which is brought to Morocco, Fez, Algiers, Cairo, and Alexandria. The gold, as is often the case, is accompanied with grains of iron ore, probably the magnetic or black iron ore. Gold mines occur to the south of Timbuctoo. The people employed in these minesare Bambarra negroes, who become wealthy, as all the particles of gold under a certain weight (12 mizams) belong. to them. Pieces of gold, weighing several ounces, are sometimes found there. The country of Kordofan, to the south-east of the Great Desert, affords a considerable quantity

* Geol. Tr., vol.i., New Series, p. 418. 
of gold. The precious metal found in that country is brought to market by the negroes, in quills of the ostrich and vulture. This territory, it would appear, was known to the ancients, who regarded Ethiopia as a country rich in gold. Sulphur is said to occur in Darfur.

4. Great Table-land of Africa.-Of the table-land itself we know very little, - the geological details we are now to lay before our readers being principally illustrative of the mountain-ranges and acclivities that surround this elevated plateau.

Geology of the Coast from Sierra Leone to Cape Negro. -We shall trace the geological phenomena from Sierra Leone to Cape Negro. The hills around Sierra Leone are of granite, or rather of a porphyritic granitic syenite, in which tourmaline crystals occur.* We know nothing whatever of the geology of the Grain Coast and Ivory Coast of Guinea. The Gold Coast is so named from the great trade in gold dust carried on there, which has given rise to many European settlements. We are told that in the interior there are mountains of granite, gneiss, and quartz, and that the gold is collected from the alluvial sands and clays formed from these rocks. Nothing particular is known of the rocks or soils of the Slave Coast.

Our young friend and pupil, Thomas Park, son of the celebrated but unfortunate Mungo Park, possessing the enthusiasm and courage of his father, determined on traversing Africa, with the view of ascertaining the history of his father's fate, at that time in some degree unknown, and also of enlarging our knowledge of its natural history and geography. He was landed by order of government at Accra, on the west coast, in $5^{\circ} \mathrm{N}$. The last letter we received from this promising young traveller, - for shortly after the commencement of his journey he perished,-was as follows :- "Accra, 17th September, 1827.-I intend to set off to-morrow morning. I have been, as you know, three months here, during which time I have been principally busy with the study of the Ashantee language. Some time ago I made an excursion of about fifty miles into the interior, by way of experiment, and did not fail to look around me and notice the rocks and other natural produc. 
tions. I have only time to say, that the valley of Accra is about 12 miles in breadth, and 50 miles in length; the bottom is covered with a soft sandstone, and this sandstone, in one place, was observed resting upon clay-slate. The mountains forming the sides of this long valley, as far as I could observe, appear composed of quartz rock and clayslate, alternating with each other, and disposed in strata ranging S.S.W. and N.N.E., the dip from $30^{\circ}$ to $80^{\circ}$ (the direction of the dip not mentioned). The quartz rock contains grains of gold, as I ascertained by careful examination. In some blocks of rock (syenite) I noticed a good many crystals of sphene, and in one place saw what I considered to be black manganese ore. It is very hard and heavy, and is fashioned by the Ashantees into balls. The cover of alluvium, in the bottom of the valley and extending down to the seacoast, is of such a nature as to lead me to conjecture that it is of marine origin, and, therefore, that the sea formerly extended a long way inland. The bases of the hills are richly clothed with trees; but these diminish in number towards the coast, where there occurs only a bush here and there."

The occurrence of gold in the quartz rock, as ascertained by Mr. Park, is a very interesting observation, as it allows us to infer that probably much of the gold collected in Africa may have been derived originally from this kind of rock, which, in its broken down and disintegrated state, may have formed the sands and gravels in which gold dust is generally found,

In Benin there are mountains (those of Cameroon on the seacoast) said to be 13,000 feet high. The Congo district, through which the Zaire flows, was examined for some distance up the river. The rocks met with were granite, syenite, primitive greenstone, gneiss, mica-slate, clay-slate, and primitive limestone or marble.

The kingdom of Angola contains salt pits, from which are extracted large slabs of solid rock-salt. According to Battel, beds of rock-salt, three feet thick, extend over a considerable part of the province of Dembea.

The mines of Loango and Benguela furnish good iron. Copper and silver ores are said also to occur in Angola, particularly in the kingdom of Majomba. There are also some considerable mines of copper in Anziko. 
Bamba, situated on the coast, has large salt pits. Its mountains, rich in metals, extend as far as Angola. The province of Sandi contains ores of iron and of yellow copper ore.

'The coast from Cape Negro, in lat. $16^{\circ} \mathrm{S}$., to the mouth of the Orange River, an extent upwards of one thousand miles, consists of sand hills, without a tree or drop of water, having in this great space only three bays, which are completely, exposed to the north-west wind, viz. the Great Fish Bay, Walvisch Bay, and Angra Pequina. The geology of this coast is entirely unknown.

Cape of Good Hope District.-This district is bounded on the north and east by the Orange and Fish Rivers; on the west and south by the ocean. The country extends from S. lat. $26^{\circ}$ to $\mathrm{S}$. lat. $33^{\circ} 55^{\prime} 40^{\prime \prime}$, that of the Cape of Good Hope. It includes the country inhabited by the Hottentot race and the Boshuanas.

Distribution of the Chains of Mountains, Plains, and Valleys or Kloofs. - Two great chains of mountains run parallel with the western coast, having between them and the coast a sandy plain from five to ten miles in breadth. From the most easterly of these two chains branch off three others, running in a direction parallel with the equator, between which are the like number of terraces, including altogether a space of between two and three degrees of latitude. The two southernmost of these chains are united at several points with the western, and form the vast ridges which, under the names $Z$ wartebergen or Black Mountains, run like a steep wall from west to east, broken only at intervals by the streams which flow from them from the Karroo. The two principal of these chains terminate at Kromme-Rivers' Bay and at. Algoa Bay. Smaller branches run down to Mossel Bay and Plattenbergs Bay. The level country between the southern chain and the coast constantly decreases in breadth, from the spot where this. chain branches off from the western mountains till it is lost near Kromme Rivers' Bay. Towards the north several long and spacious valleys run between the chains of the Black Mountains, the principal of which are, the Kokman's Kloof, Kango, the Valley of the Elephant River, and Long Kloof. It is only at a few points, and even at these not without some danger and difficulty, that the Black Mountains can 
be crossed to the terrace north of them, and which is some thousand feet higher than the other two terraces, known under the name Great Karroo.* The tract enclosed between these two chains of mountains is partly fertile, but interspersed with tracts of arid clay-land called Karroo. This plain or terrace, forming the third terrace of Southern Africa, about 300 miles in length and 80 in breadth, and principally a parched desert, occupies the whole of that very large space lying between the Black Mountains, and the third great branch from the western hills, called the Nieuweveld Mountains. These latter again unite themselves, after running for a long extent from west to east, with another chain of mountains running from north to south, forming at their junction that remarkable group of mountains called the Sneuwbergen or Snow Mountains. The Nieuweveld and Sneuwberg Mountains are said to be the highest in Southern Africa, some of them being 10,000 feet above the level of the sea. The country, from this vast range of mountains to the northern boundary of the Cape Colony, may be con: sidered as a lofty plain, part indeed of the great Table-land of Africa, free from large mountains, but here and there varied with ranges and hills of moderate dimensions, having very few rivers, and all of these nearly dried up in-summer ? quite destitute of trees and grass, but every where covered with bushes springing out of a naked red soil, deprived of moisture during a great part of the year. The bushes are not more than a foot or two in height, excepting various kinds of lycium, and almost exclusively belong to the natural order of composite flowers. One general cast of fea: tures, not peculiar, however, to this district, pervades all these vegetables, - a minute and arid foliage. Yet on these all the cattle browse, and such wild animals as-are herbivoz rous. The mountains vary in form; the most prevalent shape is the tabular; and of these splendid displays occur in many parts of the country, which are well represented in the plates in Professor Lichtenstein's Travels, and alsa in those of Mr. Burchell. Deep and extensive cliffs are of frequent occurrence, exhibiting all the magnificent scenery so characteristic of the great sandstone or quartz formation,

* The word Karroo, written Karro by Burchell, belongs to the Hot tentot language, and signifies $d r y$ or arid. 
which predominates in Southern Africa. The mountainranges are in many places traversed by deep valleys, named kloofs. These are the passes that lead across from one part of the country to the other, and which appear to have been originally vast rents, which have become wider by the action of the atmosphere and running water. The inclined plain, or space between the most southern range of mountains and the seacoast, varies from 20 to 60 miles in brealth, and, reckoning from the interior of the country, forms the third terrace of Southern Africa. The flat tract enclosed between the southern chain and the Zwarteberg forms the second terrace. 'The vast tract, or the Great Karroo, contained between the Z $\mathbf{Z}$ warteberg and the Nieuweveld Gebirgte, is the first terrace. The second and first terraces, which contain so much Karroo ground, may formerly have been inland seas or lakes. The great bank of gravel, sand, and clay which ranges along the coast and under the sea, from the Cape of Good Hope to Natal, and to south lat. $37^{\circ}$, may be considered as another terrace.

Description of the Karroo Plains.-The Karroo ground, which forms so striking a feature in the external aspect of the Cape district, is loam or sandy clay, mixed with particles of ochre of iron. Lichtenstein says it is not more than a foot in thickness. This may apply to some, but by no means to the greater number of localities. From the nature of the soil, and other concomitant causes, the vegetation must at all times be very meager; and in summer, when the sun has dried the soil to the hardness of brick, it ceases almost entirely. The mesembryanthemum, and some other succulent plants ; some kinds of gorteria, of bergia, and of asters, whose roots, like the bulbs of lilacious plants, nature has fortified with a tenfold net of fibres under the upper rind, to protect them against the hardened clay : such plants alone resist the destructive nature of this inhospitable soil,

As soon as, in the cooler season, the rains begin to fall and penetrate into the hard layer of loam, these fibres im. bibe the moisture, and, pushing aside the clay, the germ of the plant, under their protection, begins to shoot, and in a few days the arid waste is covered with a delicate green covering. Soon after, myriads of flowers ornament the whole surface. "The mild midday sun," says Lichten. stein, "expands the radiated crowns of the mesembryan. 
themums and gorteriæ, and the young green of the plants is almost hidden by the glowing colours of their full-blown flowers, while the whole air is perfumed with the most fragrant odour. The odour is more particularly delightful, when, after a calm day, the sun declines, and the warm breath of the flowers rests quietly on the plain. At this time the whole dreary desert is transformed into one continued garden of flowers. The colonist, with his herds and his flocks, leaves the Snowy Mountains, and, descending into the plain, there finds a plentiful and wholesome supply of food for the animals; while troops of the tall ostrich and the wandering antelope, driven also from the heights, share the repast, and enliven the scene. But. how soon is the country again deprived of all its glory! It scarcely continues more than one month, unless late rains, which must not often be expected, call forth the plants again into new life. As the days pegin to lengthen, the increasing power of the midday ray checks once more the lately awakened powers of vegetation. The flowers soon fade and fall, the stems and leaves dry, and the hard coat of soil locks up the germs until the rains return; the succulent plants alone still furnish food for the herds and flocks. The streams soon begin to dry, the springs almost cease to flow, till at length the universal drought compels the colonists to return to the mountains; yet even then they quit the plain with reluctance, and the flocks, accustomed to endure thirst, still linger behind, feeding on the succulent plants, which afford at once food and drink, and are particularly salutary to those that bear wool. Every day, however, the Karroo becomes more and more solitary, and by the end of September it is wholly deserted. The hardened clay bursts into a thousand cracks, which evince to the traveller the great power of an African sun. Every trace of verdure is vanished, and the hard red soil is covered over with a brown dust, formed from the ashes of the dried and withered plants. Yet among these ashes is the seed nourished that is to produce future generations, and the relics of one year's vegetation furnishes manure that is to cherish the germs till the next year's rain again brings them forth."

Lichtenstein thus describes his first view of the Great Karroo:-"The space between the mountain-ranges is the Great Karroa, as it is called a parched and arid plain, 
stretching out to such an extent that the vast hills by which it is terminated are almost lost in the distance. The beds of numberless little rivers cross, like veins, in a thousand directions, this enormous space; the course of them might in some places be clearly distinguished by the dark-green of the mimosas which spread along their banks. Excepting these, nowhere, as far as the eye could reach, was a tree to be seen, nor even a shrub, or any signs whatever of life."

As the geology of the country in the vicinity of Cape Town is that best known to us of any part of Southern Africa, we shall first describe the arrangements observed in that quarter, and afterward notice what is known of the rocks of other parts of this division of Africa.

Geognosy of the Peninsula of the Cape of Good Hope:The peninsula of the Cape of Good Hope is a mountainous ridge, stretching nearly north and south for forty or fifty miles, and connected on the east side, and near its northern extremity, with the main body of Africa, by a flat sandy isthmus, about ten miles broad, having Table Bay on the north of it, and False Bay on the south. The southern extremity of this peninsula, extending into the sea, with False Bay on the east, and the ocean on the south and west, is properly the Cape of Good Hope, and is nearly the most southern point of Africa. At this point the chain of mountains which forms the peninsula, though rugged, is lower than at the north end, where it is terminated by Table Mountain and two others, which form an amphitheatre overlooking Table Bay, and opening to the north. The mountains of the ridges extending from the Cape to the termination of the peninsula in the north, vary in shape; but the most frequent forms incline more or less to sharp conical. The three mountains that terminate the peninsula on the north are, the Table Mountain in the middle; the Lion's Head, sometimes called the Sugar Loaf, on the west side; and the Devil's Peak on the east. The Lion's Head, which is about 2160 feet above the level of the sea, is separated from the Table Mountain by a valley that descends to the depth of 1500 or 2000 feet below the summit of the Table Mountain, which is itself 3582 above the level of the sea. On the west of the Lion's Head there is a lower eminence, named the Lion's Rump, 1142 feet high, 
from which the ground declines gradually to the sea. The amphitheatre formed by these three mountains is about five or six miles in diameter, in the centre of which is placed Cape Town.

The rocks of which this peninsula is composed are few in number, and of simple structure. They are granite, gneiss, olay-slate, greywacke, quartz rock, sandstone, and augitegreenstone, or dolerite. Of these the most abundant are granite and sandstone; the next in frequency are clay-slate and greywacke; and the least frequent are gnieiss and dolerite. In some parts, as at the Steinberg, the sandstone is traversed by veins of red iron ore. Abel mentions a vein six feet wide, and extending for upwards of one hundred feet.

The strata of the Neptunian rocks, or those whose formation is connected with the operation of water, generally range from west to east,- that is, across the peninsula. The southern and middle parts of the peninsula have been but imperfectly examined. Captain Hall remarks, that the same general structure and relations seem to occur all over the peninsula as in the mountains around Cape Town. The late Dr. Clarke Abel, in the account of his voyage to China, gives the following description of a fine display of stratification in a mountain that faces the sea, in the neighbourhood of Simon's Bay, which was pointed out to him by one of our pupils, an active and intelligent officer, Captain Wauchope, R. N. :- "The sandstone forming the upper part of the mountain is of a reddish colour, very crystalline in its structure, and approaching, in some specimens, to quartz rock. Immediately bèneath the sandstone is a bed of compact dark-red argillaceous sandstone, passing, in many places, into slate of the same colour. This bed rests upon another of very coarse loosely-combined sandstone, resembling. gravel. Under this is another layer of dark-red sandstone, terminating in a conglomerate, consisting of decomposed crystals of felspar, and of rounded and angular fragments of quartz, from the size of a millet-seed to that of a plover's egg, imbedded in a red sandstone base. Beneath the conglomerate commences a bed, which I at first took for granite, and which is composed of the constituents of granite in a decomposed state, intermixed with green steatite, and a sufficient quantity of the red sandstone 
to give it a reddish hue. The felspar of the bed is decomposed, and exactly resembles that of the conglomerate above it. The mica seems, in a good measure, to have passed into steatite. The quartz is in small crystals, frequently having their angles rounded. This bed is several feet in thickness, and gradually terminates in the granite; but the precise line of junction I was unable to trace. The appearances thus were in the following order :-

1. Horizontally-stratified sandstone.

2. Bed of compact dark-red sandstone, passing into slate.

3. A bed of coarse sandstone resembling gravel.

4. A second layer of compact dark-red sand stone, passing,

5. Into a conglomerate, consisting of decomposed crystals of felspar, and fragments of quartz in a sandstone basis.

6. A bed composed of the decomposed constituents of granite and red sandstone, passing,

7. Into granite."

The above is the only spot to the southward of the range of mountains near Cape Town which has been particularly described in a geognostical view. To the northward of Cape Town, it is said that the mountains are principally composed of the same rocks as those which occur throughout the peninsula, and whose characters and position have been exanined with considerable attention in the Lion's Rump, Lion's Head, Table Mountain, and Devil's Peak, by our pupils the late Dr. Clarke Abel, Dr. Adam, now of Calcutta, the late Captain Carmichacl, and also by Captain Basil Hall. From the observations furnished to us by these naturalists, and also from accounts published by them, we have drawn up the following description :-

Lion's Rump.-The Lion's Rump rises by an easy ascent, and, excepting at one or two points, is covered to the summit with a thin soil, bearing a scanty vegetation. Dr. Adam informs us that vegetables appeared to be most luxuriant over the sandstone of the peninsula, but less so on the soil formed by the decomposition of the granite, and, least of all, over clay-slate, as on the Lion's Rump, where clay-slate is the predominating rock. Although this latter hill has been cultivated in some places, yet it presents a 
stunted vegetation; while the upper part of Lion's Head and Table Mountain, though much more elevated, display tich and more vigorous shrubs.* It is composed of clay-. slate, greywacke, and sandstone. The clay-slate and greywacke appear to alternate, and the sandstone rests upon: the slate. The slate is distinctly stratified; the strata on one side of the hill dip to the north, on the opposite to the south, and in the middle or centre of the hill they are nearly perpendicular. Numerous veins of compact quartz traverse the strata in all directions. A quarry, which has been wrought to a considerable extent on the east side of the hill, exhibits a fine view of the structure of the clayslate, and in one place thiere is a bed of sandstone in the slate. The sandstone, which is of a yellowish-gray colour, is composed of grains of quartz, with disseminated felspar and scales of mica.

Lion's Head.-The strata of clay-slate continue to the base of the Lion's Head. Here they are succeeded by strata of compact gneiss, composed of gray felspar and quartz, with much dark-brown mica in small scales. It much resembles the gneiss interposed between granite and clay-slate in the transition mountains in the south of Scotland; as at Criffel, and near New Galloway in Kirkcudbrightshire. The gneiss is distinctly stratified, and the strata in some places dip under the next rock, which is granite; in others, they dip from it. Numerous transitions are observed from the granite into the gneiss; and in the same bed of compact gneiss, one part will be gneiss, while another will be granite. Beds of granite, in some places, appear to alternate with the gneiss. Veins of granite, from a few inches in width to several feet, traverse the gneiss and clay-slate, and are observed projecting from the body of the granite, and shooting among the neighbouring slaty strata.

* Constantia, so celebrated for its wine, is situated at the bottom of the range leading frorn Cape Town to Simon's Bay, where sandstone is the predominating rock; and the soil of the farms of the neighbouring ground appears to be composed of it, in a state of decomposition, and of vegetable mould. That it is the sandstone which essentially contribures to the excellence of the soil Dr. Adam is inclined to believe, from having observed several spots at the foot of the same range, nearer Cape Town, with a soil richer in vegetabe mould, but whose prodnce was held much inferior. The principal rock there was granite, and its superincumbent sandstone has suffered less decomposition than that adjoining to Con atantia, 
Granite forms a considerable portion of the Lion's Head. It is composed of pale-red felspar, gray quartz, and brownish-hlack mica. It is more frequently coarse granular than fine granular, and is often porphyritic. It is occasionally traversed by veins of quartz, or of felspar, or of granite. In some parts the granite is traversed by veins of dolerite or augite-greenstone, and one of these veins, as described by Dr. Abel, appears divided and shifted. This appearance is represented in No. 3 of Dr. Abel's Geological Views' at the Cape of Good Hope. As we ascend the mountain, we find the granite succeeded first by a reddish sandstone, and this, in its turn, is covered by a brown sandstone that reaches to the summit. These sandstones are principally composed of granular concretions of quartz, with a few disseminated grains of felspar and scales of mica. The sandstone is distinctly stratified, and the strata dip at a small angle all around the Lion's Head and the north-west side of the Table Mountain. On the opposite side of the latter, however, from the seabeach, we may see it, beyond the gorges, making an angle with the horizon of not less than $45^{\circ}$. Dr. Adams says, "During a ride to Constantia one day, I observed this high inclination more particularly on the ridge extending from the Devil's Peak by Simon's Bay: and, having afterward visited the spot on purpose, found the sandstone very much elevated in its position above the common level of the strata, and, at one place, nearly perpendicular to the horizon, running from north-east to south-west."

Table Mountain.-The next and highest mountain, the' Table Mountain, presents many interesting appearances. The lowest part of the mountain, on one side, is red sandstone; higher up, and apparently rising from under it, are clay-slate, greywacke, and gneiss. These rocks are disposed in strata, arranged nearly in a vertical position, with an east and west direction. They are intermingled with granite, which is the next rock on the ascent of the mountain. The granite, at its line of junction with the slate, both gneiss and clay-slate, is often much intermixed with them; and numerous veins of granite shoot from the mass of the granite rock itself into the bounding strata. At a higher level than the granite, sandstone makes its appearance, and continues upwards to the summit of the mountain. The lowest of the summit sandstone is of a reddish 
colour; the next above it is of a yellowish colour; and tho upper part, or that on the summit, is of a gray or beautifully white colour, and sometimes so coarsely granular as to appear in the state of conglomerate. In many places, the sandstone passes into quartz rock, and is rery highly crystalline. The sandstone is distinctly stratified, and nearly horizontal.

Devil's Peak.-The most easterly mountain of the group we are describing, named the Devil's Peak, agrees with Table Mountain in the nature and arrangement of the rocks of which it is composed. The lower part of the mountain exhibits strata of clay-slate; these, as we ascend, are succeeded by granite; and the upper parts and summit are of the usual varieties of sandstone.*

* The following particulars, in regard to the mountains near Cape Town, were communicated to us by Captain Carmichael. The Table Mountain and Lion's Head rest upon a base of granite; Green Point, Table Valley, and the Devil's Peak, on a base of slate, of which the whole of the Lion's Back or Rump is composed. The granite extends up to the. rocky crown of the Lion's Head,-an elevation of nearly 1500 feet; and the declivity of the mountain is strewed with enormous masses of it. On the side of the Table Mountain, the space on which the granite is visible is contracted to about 500 feet, and occupies the centre of the declivity. At the spot called Sea Point, the granite and slate come in contact. In the space of 200 yards along the shore, the reef is a mixture of these two rocks, each predominating in the mass as you approach its respective side, where it is pure and unmixed. In some parts they form alternating layers; in others, fragments of the slate, of all fgures and sizes, lie imbedded in the granite, which appears to have pervaded their minutest fissures. Between this mixed mass, however, and this pure s!ate, there is interposed a ramipart of granite, apparently different from the common sort, which, for about 200 yards, is unmixed; but, as it approaches the slate, becomes mingled with it in the same ma:ner as the granite. From this to Green Point, and extending through Robben Island, a distance of about twelve miles, the slate is pure, and disposed in nearly vertical strata.

Close to the path which leads from Cape Town to the summit of the Table Mfountain, there runs a stream, which, at the point where the granite and slate meet. has carried off the superincumbent earth, and exposed the surface of the rock from ten to twenty yards in fiameter, and about 200 yards in length, dipping at sn angle of about $30^{\circ}$. Along the whole of this space the slate is intersected by veins of granite, varying from three feet in width to as many lines. The veins branch off in all directions, some straight, others twisted in the most fantastic convolutions. In the face of the rampart which borders the channel on each side, the veins are equally conspicuous. In walking along the shore, from Campo Bay to Sea Point, we meet with numerous veins of augitegreenstone in the granite, rarying in breadth from an inch to ten feet, and branching in as many directions as those of the granite with the slate. Here also are to be seen numerous fragments of slate in the granite. 
To what Class of Rocks do those of the Cape Peninsula. belong?-To what class or classes of formations of the geognostical series are we to refer the rocks of the mountains just described? From the clay-slate containing beds of greywacke, we infer that the slate belongs to the transition class;-from the granite being intermingled with the slate, we consider it as probably belonging to the same epoch. The sandstone is generally considered as belonging to the secondary class, - an opinion, the accuracy of which may be questioned; because we find this rock in beds in the slate, and also passing into and alternating with beds of a transition rock, namely, quartz rock. This being the case, we are disposed to refer it also to the transition class; and the great mass of it to the newest or uppermost portion of the series.

At what Period did the Cape Rocks rise above the Level of the Sea? - This question has been variously answered, according to the geological creed of those who have considered the subject. The Neptunians maintain, on plausible grounds, that all these rocks are 'crystallizations and deposites from the ancient waters of the globe, which have taken place in succession,- - the granite being the first forn:ed, the slate and greywacke the next, and last of all, the principal portion of the sandstone; that, during the deposition of these different rocks, the level of the ocean gradually sunk; and that thus the mountains rose above its surface. The Plutonians, or the supporters of the igneous origin of the granular crystallized rocks, view the formation in a different manner. Some of the advocates of the igneous system maintain, that the slate was first deposited in borizontal strata, at the bottom of the sea,- that these strata were afterward softened by heat, and raised from their original horizontal to their present highly inclined position, by the action of fluid granite rising from the interior of the earth; and that in this way the granite and slate mountains were elevated above the sea: that the sea again invaded the land and covered it to a great depth; and that from this ocean was deposited the sandstone strata: that the sea again

The sandstone which forms the upper part of the Table Mountain, Lion's Head, and Devil's Peak lies on horizontal strata, intersected by vertical fissures. It is of a siliceous nature, and encloses rounded nodules of quartz. 
retired, and left exposed mountains, and chains of mountains of sandstone. Other Plutonians are of opinion that the slate, greywacke, and sandstone were deposited, in uninterrupted succession, at the bottom of the sea; and that the whole mass of stratified matter was raised gradually or suddenly above the level of the ocean, forming mountains, chains of mountains, and table-lands, by that igneous agency which sent up the granite, and probably also the augite-greenstone rocks. This, of the two Plutonian views, is the most plausible, and indeed is that explanation which may be viewed as most in accordance with prevailing geological hypotheses.

Vegetables incrustcd with Calcareous, Sand confounded with Coral, and adduced as a Proof of the very recent Emergence, from the Ocean, of the Lands supporting them.-Somewhat to the eastward of Simon's Town is a large bank, one hundred feet above the level of the sea, formed by an accumulation of sand and shells, brought there by the action of the wind. On this bank Abel observed a number of cylindrical calcareous bodies scattered about, which at first appeared like bleached bones. On a closer examination many of then are found to be branched, and others are discovered rising through the soil, and ramifying from a stem beneath, thicker than themselves. They are incrustations of sand and calcareous matter on vegetables. Similar bodies have been found by Vancouver, Flinders, and Perron, on the shores of New-Holland, at considerable elevations. The first-mentioned traveller considered them all as coral, and as proofs of the land having been lately withdrawn from the dominion of the waters. The last has described two kinds of substances ; the one he considers as coral, the other as incrustations on vegetables. Captain Flinders, at page 48, vol. i. of his Voyage Round the World, says, - "The appearance of this country along the coast resembles, in most respects, that of Africa about the Cape of Good Hope. The surface seemed to be chiefly composed of sand, mixed with decayed vegetables, varying exceedingly in point of richness, and, although bearing a great similarity, yet indicating a soil su perior in quality to that in the immediate neighbourhood of Cape Town. The principal component part of this country appeared to be coral; and it would seem that its elevation above the ocean is of modern date, not only from the shores and the bank which extends along the coast being, generally 
speaking, composed of coral, as was evident by our lead never descending to the bottom without bringing up coral on its return, but by coral being found on the highest hills we ascended, particularly on the summit of Bald Head, which is sufficiently above the level of the sea to be seen 12 or 14 leagues distant. Here the coral was entirely in its original state, particularly in one level spot, comprehending about eight acres, which produced not the least herbage on the white sand that occupied this space, through which the branches of coral protruded, and were found standing exactly like those seen in the beds of coral beneath the surface of the sea, with ramifications of different sizes, some not half an inch, others four or five inches in circumference. In these fietds of coral (if the term field be allowable), of which there were several, seashells were in great abundance,some nearly in a perfect state, still adhering to the coral, others in different stages of decay. The coral was friable in various degrees; the extremities of the branches, some of which were nearly four feet above the sand, were easily reduced to powder, while those close to or under the surface, required some small force to break them from the rocky foundation from whence they appeared to spring. I have seen coral in many places at a considerable distance from the sea; but in no other instance have I seen it so elevated and in such a state of perfection." Captain Flinders, at page 63, vol. i. of his Voyage to Terra Australis, has the following remarks on the same appearance:- "Captain Vancouver mentions having found, upon the top of Bald Head, branches of coral protruding through the sand, exactly like those seen in the coral beds beneath the surface of the sea,--a circumstance which should seem to bespeak this country to have emerged from the ocean at no very distant period of time. This curious fact I was desirous to verify, and his description was proved to be correct. I found also two broken columns of stone, three or four feet high, formed like stumps of trees, and of a thickness superior to the body of a man ; but whether they were of coral, or of wood now petrified, or whether they might not have been calcareous rocks, worn into that particular form by the weather, I cannot determine. Their elevation above the present level of the sea could not have been less than 400 feet."

Perron says, "On breaking the branches where the inA a 2 
crustation is recent, we observe the woody texture contained in a solid case, and without any remarkable alteration; but in proportion as the calcareous envelope increases, the wood becomes disorganized, and changes insensibly into a dry and black powder." From this state he supposes the centre gradually to increase in solidity till the whole mass becomes a mere sandstone, and nothing but an arborescent form indicates the ancient state of vegetation.

The incrustations near Simon's Town are of a similar na. ture to those found in New-Holland, because, says Dr. Abel, the descriptions of authors correspond with the appearances I have witnessed, and because I have compared a specimen brought from Bald Head in New-Holland, by Mr. Brown, with those I obtained at the Cape, and can trace no essential difference, either in the external characters or chemical composition. It follows from this statement, that Flinders and Vancouver have confounded vegetable in. crustations with true. corals; and hence the reasoning on their supposed submarine origin, and modern rising of the Bald Head, \&c. above the level of the ocean, is incorrect.

Geology of the North and South, and East and West Ranges of Mountains. - The ranges of mountains which run northward from the Cape Peninsula to Orange or Gariep River, in the points where examined, exhibited granite and slate, with vast deposites of sandstone or quartz rock with numerous table-shaped summits,-thus showing a similarity of composition in these mountains to those of the Cape Peninsula.

The three great ranges of mountains that run from east to west, according to the reports of travellers, are of the same general nature, and eminently characterized by the vast abundance of sandstone reposing in horizontal strata upon the granite and slate, forming the middle, and very often the higher parts of the chains.

Geology of the Table-land.-From the third range onwards to lat. $300 \mathrm{~S}$., the prevailing rock in the plains and hills is sandstone. At Dwaal River, the frontier of the colony, there are rocks of augite-greenstone and basalt, probably in veins traversing the sandstone. Rocks of the same description, disposed in beautiful globular concretions (not boulders, as stated by Burchell), occur near to Kaabes $\mathrm{Kraal}, 29^{\circ} \mathrm{S}$. lat., probably in veins traversing the horizontal sandstone of that district. The Karreebergen, or Dry 
Mountains, beyond the limits of the colony, form a range from five to ten miles broad, and range through the country to an unknown distance, from N.E. to S.W. These mountains are principally composed of sandstone, in horizontal strata, and every where exhibit beautiful tableshaped summits. According to Burchell, "The sandstone rock continues onward to lat. $30^{\circ} \mathrm{S}$., to near Modde or Mud Gap, where true quartz strata and vesicular trap-rocks make their appearance. In lat. $29^{\circ} 15^{\prime} 32^{\prime \prime} \mathrm{S}$., mountains, called the Asbestos Mountains, of clay-slate, disposed in horizontal strata, occur; there layers of asbestos occur in the slate. This asbestos is blue and yellow, and the fibres sometimes nearly three inches in length." In the same mountain, according to Burchell, green opal and pitchstone also occur. A range of black craggy mountains extends from the Kloof, in the Asbestos Mountains; the rocks are very probably trap. Further to the north, at Klaarwater, are vast beds of horizontally stratified limestone, without organic remains.

Account of the Sibilo of the Afrucans.-At Sensavan, or Blenk-Klip, nearly in S. lat. $28^{\circ}$, there is a ridge of quartz rock impregnated with micaceous iron ore, which, in many places, is collected into nests of considerable magnitude. This ore of iron is known throughout Southern Africa by the name Sililo. Hither all the surrounding nations repair for a supply of that ornamental and, in their eyes, valuable substance. It forms, in some degree, an article of barter with more distant tribes, and even among themselves; so that the use of it extends over at least $5^{\circ}$ of latitude. It is of a reddish colour, soft and greasy to the feel, -its particles adhering to the skin, and staining it of a deep red colour. The skin, says Burchell, is not easily freed from these glossy particles, even by repeated washing. The mode of preparing and using it is, simply grinding it with grease, and smearing it generally over the body, but chiefly on the head; and the hair is often so much clotted and loaded with an accumulation of it, that the clots look like lumps of the ore.

From the north of Sensavan to Lattakoo, the rocks are limestone without petrifactions, granite, and slate. In conclusion, it may be remarked, that as far as is known at present, the whole of the table-land of Southern Africa, to the 
north of the Orange or Gariep River, is composed of horizontal limestone without petrifactions, clay-slate, sandstone or quartz rock, granite, greenstone, serpentine, and potstone. The most remarkable geological feature of the country is the horizontality of the strata,--thus intimating their undisturbed state.

Geological Survey of the Karroo Ground recommended.To geological travellers we recommend a particular examination of the compact clay-ground called Karroo, which, if a deposite from ancient lakes, may prove to be a tertiary formation. The surface only of the Karroo ground has been described; for, as far as our information goes, no accounts have been published of its internal structure and arrangement. It is by the study of the structure and arrangement of its layers, and the careful examination of the minerals, rocks, organic remains (if any) it contains, and its chemical composition, that we can acquire a distinct conception of its true nature.

\section{RIVERS.}

The rivers of Africa, as far as connected with those regions of this continent described in the present volume, have been already particularly considered. As much, however, still remains to be known in regard to them, we may add, that the attention of travellers, in investigating their natural history, should, besides their geographical distribution, be directed towards the various circumstances connected with their fall, velocity, quantity of water they contain, their eddies, freshes, and bore, if any such occur; also, the nature of their beds, inundations, occultations, temperature at the surface, or at different depths; their cascades and rapids; their water, as to colour, transparency, and chemical composition; and they should not omit descriptions of the river scenery considered by itself, and also in reference to the surrounding country ; and, lastly, the climate, and effects of the climate, and of the scenery of the rivers, on man, ought also to form objects of inquiry.

\section{SOUTH AFRICAN LAKES.}

In Southern Africa, lakes are but seldom met with, and among these, some few are salt. The most considerable salt lake hitherto met with by travellers, is that near to 
Algoa Bay. It is resorted to by the inhabitants from very distant parts of the colony, for the purpose of procuring salt for their own consumption or for sale. It is situated in a plain considerably elevated above the level of the sea, is of an oval form, and about three miles in circumference. It is named Zoutpan or Saltpan, an appropriate name, as the sun and wind do here what is effected in salt-works by artificial heat. When Mr. Barrow examined it, the greatest part of its bottom was covered with one continued body of salt, like a sheet of iee, the crystals of which were so united that they formed a solid mass as hard as rock. The dry south-easterly winds of summer, agitating the water of the lake, produce on the margin a fine, light, powdery salt, like flakes of snow. This is equally beautiful as the refined salt of England. Another salt lake, according to Lichtenstein, occurs on the western coast of the colony near to Elephant River, from which the inhabitants of the district supply themselves with this necessary of life. A salt lake of considerable extent is said to occur in about $\mathbf{S}$. lat. $30^{\circ}$, in the upper part of the river-district of the Orange River. The most northern, of which I have been able to gain any intelligenee, says Burchell, is one about the $27^{\circ}$ S. lat., eastward of Lattakoo. The Karroo clay, as already mentioned, is probably a deposite from lake water, at a time when the tracts where it occurs were covered with water.

Particulars to be attended to in investigating the Natural History of Lakes.-Travellers, in examining and describing lakes, ought to ascertain their relations to rivers and springs, their magnitude, depth, temperature at the surface and at various depths, their colours, occultations, and agitations. The water of the lake ought to be submitted to chemical analysis, in order to ascertain whether it is fresh water, salt water, alkaline water, calcareous water, \&c. Their mode of formation ought also to be considered, and the peculiar characters of lake scenery and climate should be attended to.

SOUTH AFRICAN SPRINGS.

The springs of Southern Africa may be divided into com. mon, hot, and mineral.

Common Springs.-Although much rain falls in the Cape district, it affords but comparatively few springs, 
This paucity of springs may be explained, as Mr. Barrow remarks, by attending to the nature of the rocks, and their mode of arrangement. Where two of the formations of the district occur together, as sandstone and granite for example, and the sandstone lies upon the granite, whose upper surface is above the level of the neighbouring country, springs will occur abundantly around the line of junction of the two formations. In this case the water percolates through the sandstone, which is a porous rock; but its farther progress downwards is arrested by the granite, which is a dense and compact rock, and therefore, when it reaches the surface of the granite, it accumulates there, and either remains stationary, or flows along its surface, until it finds an opening at the surface, where it issues forth in the form of springs. On the contrary, if the sandstone deposite rests upon granite, whose upper surface is below the level of the surrounding country, the percolating water, on reaching the granite, will accumulate there, and flow off by rents into the lower and distant parts of the country, but few springs will be observed issuing from the sandstone.

Hot Springs.-The only hot springs particularly described by travellers are those of Brand Valley and Zwarte= berg.

Brand Valley.-The hot spring here is larger than that at $\mathrm{Z}$ warteberg. It forms a shallow pond of about fifty feet across, of the most transparent water, in the middle of which several strong springs bubble up through a bottom of loose white sand, and afterward flowing in a very copious stream, become a rivulet, which, for at least a mile and a half, continues so hot, that its course along the valley may, at any time of the day, but more particularly early in the morning, be traced by the steam which perpetually arises from it. The pond is sheltered by a small clump of white poplars, which thrive perfectly well, although growing at the very edge of the water, and bedewed with the hot steam, which ascends to their highest branches. No plant, it seems, can grow in the water itself; but the margins of the bank are thickly covered with sedge, particularly cyperus fascicularis. Royena glabra, a species of rhus, and a variety of plants, stand within the influence of its heat. The thermometer, when plunged into the pond, rose only to $144^{\circ} \mathrm{Fahrenheit,}$ put to the hand it felt nearly scalding hot; so that the 
immersion could scarcely be endured for a few seconds. The water is pure and tasteless, and is used for all domestic purposes. Nothing resembling a deposition is any where observable; nor are its banks or channel at all discoloured. The hill, from the foot of which it issues, has no remarkable appearance ; at least, there is none of that black ponderous iron ore, or earth, noticed at the $\mathrm{Z}$ warteberg baths. At the distance of about 300 yards from the source, two bath-houses have been built over the stream, the heat of which, even here, is almost greater than can be borne by a person not gradually inured to it. Between the spring and the bath, where the stream has run a sufficient distance in the open air to allow it time to become a few degrees cooler, the bottom of the rivulet is covered with a beautiful seagreen conferva, waving gracefully beneath the water, like long tresses of hair. Specimens of rocks from this district, sent me by Dr. Smith, show that the waters of this spring issue from quartz rock, containing grains of white felspar in the state of porcelain earth.

Warm Bath at Zwarteberg.-This is a short mountainous' ridge, running east and west, and of secondary height. From the lower part of its southern front projects a small flat hill, out of the upper part of which issue, in several places, hot springs, the waters of which raise the thermometer to $118^{\circ}$ of Fahrenheit. The water deposites, in the channels along which it runs, an orange-coloured ochre of iron ; but, after a course of 200 or 300 yards, ceases to discolour the ground. It contains iron and sulphur, and hence has a slightly chalybeate taste. Within three yards of these hot springs there rises another, the water owhich is pure and tasteless, but is not warmer than that of the common springs of the country. Probably the springs here, as at Brand Valley, issue from quartz rock. In the vicinity of the springs, as I observe by inspection of specimens from Dr. Smith, bog-iron ore occurs.

Warm springs also occur in the valley of the Western Elephant River; others near the Eastern Elephant River, in Kamnasi Land; and a third behind Kokman's (Kogman's) Kloof; but all are of lower temperature than those of the Zwarteberg and Brand Valley. There is also a warm spring on the northern side of the Gariep, in Great Namaqualand. 
Springs of mineral vaters, of the common temperature, have been noticed in various places; one near Graaf Reynet, and another not far from Uitenbage, and one also in the Tarka; but their chemical composition has not been accurately ascertained.

Remarks on the Importance of a Knoncledge of the Natural History and Chemical Composition of Springs. -The springs of the African continent have hitberto been almost entirely neglested by trarellers, and naturalists, either through indifference or ighorance. Now, however, that scientific men hare settled in different parts of that quarter of the globe, particularly in Southern Africa, accurate details may be expected in regard to their various kinds, whether temporary, perennial, intermittent, periodical, spouting, sublacustrine, subfluvian, or submarine; their magnitude and colour; the temperature of common springs, at different elevations above the level of the sea, and during different seasons of the year; and the range of temperature of warm and hot springs. But in order to complete the history of the springs of the country, we must, besides, describe not only the rock or rocks from which they flow, but also ascertain the various relations of these rocks to those of the neighbouring mineral formations. Chemical investigations will aftord the necessary details as to the different mineral matters that enter into their composition. The remarkable animal substance met with in some European springs, and probably of more frequent occurrence than is believed, and which may be derived from the strata containing animal fossil remains, through which the spring waters percolate, ought to be looked for, because its presence will afford to the chemist an opportunity of examining a substance of a very curious nature; to the geologist, data for interesting speeulation; and to the physician, the means of judging of the mode of action of those waters containi in scrofula and other diseases in which its use is said to be so beneficial. It may happen here, as in other countries, that the springs deposite around their sources, and at greater or less distances from them, much of the dissolved and suspended foreign matter they contained, and thus gire rise to mineral formations, the external aspect and mode of "arrangement of which will illustrate geological phenomena observed among the older rock-formations of which the crust. 
of the earth is composed. Lastly, when it is known that hot springs are intimately connected with subterranean igneous agency, - that power which formerly acted so extensively in forming and modifying the rocks of which the crust of the earth is composed, and which even now continues, although on a less extensive scale, to occasion considerable changes on the surface of the earth,- - their natural and chemical history becomes very interesting from the light they shed over many important geological phenomena.

Geology of Caffraria, Natal, \&c.-The geology of the countries of Caffraria and Natal is entirely unknown. In Sofala there are said to be mines of silver; and gold is collected from the sands and gravels of some districts. The kingdom of Monomotapa, as it is called, at the distance inland of about forty days' journey from Sofala, affords gold, topazes, and rubies. The geology of the country from Delagoa Bay, in lat. $26^{\circ} \mathrm{S}$., to Cape Delgado, in lat. $10^{\circ} \mathrm{S}$., is unknown; a small quantity of gold-dust is collected in it. From Cape Delgado to the equator, the country which is under the dominion of the imam of Mascat, is unknown in a geological point of view. The country from the equator to the Straits of Babelmandeb has never been visited by any geolugist.

\section{CONCLUSION.}

From the preceding details it results,

1. That of all the quarters of the globe, Africa has the most truly tropical climate.

2. That notwithstanding its nearly insular form, its extent of coast is much less in proportion to its area than in the other quarters of the globe.

3. That the peculiar condition of the human species, the distribution and even the aspect of the lower animals and plants, and many of the characters of the African climate, are connected with its comparatively limited extent of seacoast, its extensive deserts, and arid soil.

4. That from the maritime situation of Sierra Leone and its colonization by Britain, and the connexion of the southern parts of the Great Table-land with the British settlements on the southern coasts of Africa, we may conjecture that the civilization of the negroes (if that interesting race be not destined to extirpation, as has been the fate of the abori$\mathrm{B}$ b 
gines of the New World, will be effected from these two quarters, through the energy, enterprise, and perseverance of missionaries, well instructed in the various useful arts of life, and in the simple and pure principles of Christianity.

5. That its springs, lakes, rivers, bays, and arms of the sea are fewer in number, and present more uniformity of aspect than is generally the case in other parts of the world.

6. That it is eminently characterized by its vast central and sandy deserts, its great southern table-land, and the vast expanses of Karroo ground.

7. That of all the rock formations, those of limestone and sandstone are the most frequent and most widely distributed : that natron, a rare deposite in other countries, is comparatively abundant in Africa; that salt is very widely distributed, though in some districts it is wholly deficient; but coal is wanting. And the precious stones, so frequent in other tropical regions, are here of rare occurrence.

8. That the metals, although met with in different quarters, are nowhere abundant; and that, of all the different metals, gold is the most generally distributed.

9. That no active or extinct volcanoes have hitherto been met with.

10. Lastly, that Africa is less frequently agitated by earthquakes than the other continents.

\section{CHAPTER XVIII.}

\section{Natural History of the Quadrupeds of Africa.*}

A KNOWLEDGE of the geographical distribution of animals, and of the laws which regulate that distribution, has excited a considerable degree of attention since the time of Buffon, whose writings may fairly be regarded as the first to create an interest in favour of this branch of natural history. The

* I think it proper to apprize the reader that in the three following chapters, devoted to the Zoology of Africa, several well-known and interesting species, such as the Egyptian Ichneumon, the Fennec of Bruce, 
slight observance of the physical characters and other local peculiarities of countries, which prevailed prior to that period, rendered the precise induction of general views a matter of extreme difficulty ; and, as navigators and naval adventurers of every class were indifferent to the accuracy of science, and ignorant of the valuable results which might spring from a more correct record of the localities of species, our knowledge of these lccalities did not increase in the same proportion as the species themselves. Even at the present day our collections are frequently rendered of little avail for the purposes of zoological geography, by the products of one country being intermingled with those of another: thus, the splendidly-feathered tribes of Rio Janeiro are frequently combined with the scarcely less brilliant birds of New-Holland and Van Diemen's Land; while the student of Indian entomology labours under a similar chance of error, in finding the Asiatic insects arranged by the merchant along with an additional supply from the Cape of Good Hope. These and other sources of confusion have long retarded our knowledge of the geography of animals.

The habits and dispositions of animals result from their structure, and that structure is invariably adapted to the local circumstances under which they are naturally placed. It must not, however, be supposed that the geographical distribution of species can ever form a proper basis for their zoological classification. Many natural families and genera are so extensively distributed as to be almost equally characteristic of every quarter of the globe. The wolf and the reindeer are common both to Europe and America; and the lion occurs in the forests of Asia as well as among the African deserts. These, however, are exceptions to the general rule; for it will be found, on examination, that every great continent, or extensive tract of country, though possessed of features which, to a certain degree, assimilate it to those of other regions, is yet distinguished by many characters entirely peculiar to itself, and which constitute its zoologieal aspect. Thus the kangaroo and the ornithorynchus are characteristic of, because peculiar to, New-Holland; the lamas and vicunhas are only found in South America; the

the Sacred Ibis, \&c, are intentionally omitted, as being characteristic of certain portions of the African continent, the general history of which does not fall within the scope of the present volume.-J. W. 
ostrich and the camelopard are proper to Africa; the lemurs to Madagascar; the pongo, or gigantic orang-outang, to the great Asiatic islands; and the common toad to the western countries of Europe. So also, in the order of quadrumanous, or four-handed animals, such as apes and monkeys, the division called Platyrrhini, distinguished by the breadth of the partition which separates the nostrils, occurs only in South America; while another great division, named Catarrhini, of which the nosirils are contiguous, is found only in the Old World. A naturalist would therefore find no difficulty in determining, merely from a glance at the muzzle, whether a species of this order was native to the ancient continent or the new.

Wherever the observant traveller turns his steps, he finds in every country animals peculiar to itself ; and many of these, occupying the most remote and insulated spots, are the most inadequately supplied with the means of locomotion. The mode of their original dispersion, whether from a single position, or from multiplied centres of creation, has therefore been a theme which has not unfrequently exercised the ingenuity of naturalists. The subject, however, seems to be one which scarcely falls within the scope of human intelligence; although a most ample source of interesting and legitimate speculation may be made to flow from an accurate and extended record of facts illustrative of their present distribution, the amount of genera and species, the relation which that amount bears to the animal productions of other countries, and similar numerical details.

In the present chapter, we propose to exhibit a brief sketch of the natural history of the greater portion of the African continent ; and, although our limits will not. permit us to draw an extended parallel between the zoology of that country and the animal products of the other quarters of the globe, we shall yet have occasion, at an after-period of our series, to survey the characteristic features of all the other great divisions of the earth, - and, in so doing, may afford the means of an accurate comparison between these and the subjects of our present inquiry. In the mean time, however, we shall not abstain from an occasional reference to the analogous species of other countries, whenever we shall be thereby enabled to throw any additional light upon the his tory of the African tribes. 
Most nearly allied to the human race of all the species of the brute creation, the black or African orang-outang (Simia troglodytes of Linnæus) may be allowed to assume the foremost place in our enumeration. It is native to no other country than Africa, although we are as yet unacquainted with the extent of territory which it occupies in tilat continent. Angola, the banks of the river Congo, and all the districts which border the Gulf of Guinea, are the localities in which it has as yet most frequently occurred. Its history, like that of its Asiatic congener, the red orang-outang (Simia satyrus, Linn.), is still involved in considerable obscurity. Its habits, in the adult state, are extremely retired and wary; and the young alone have fallen into the hands of Europeans in modern times. Great exaggeration prevails in the narratives of all the earlier travellers regarding the sagacity of this singular animal. Its external figure and general conformation no doubt greatly resemble those of the human race, and hence its actions have to us much of the semblance of human wisdom. But a remarkable circumstance in the mental constitution of this tribe of animals disproves their fancied alliance to mankind,-the young are gentle, obedient, and extremely docile,-but as they increase in ycars their dispositions undergo a striking change, and their truly brutal nature is evinced by an unusual degree of untractable ferocity. In the wild state they are inferior both to the dog and the eiephant in sagacity, although their analogous structure never fails to impress the beholder with a belief that they resemble man in mental character as well as in corporeal form. Two species of African orang-outang seem to have been described by the earlier writers. These were probably the young and old of the same species seen apart at different times, for later researches do not lead to the belief of there being more than one.

"The greatest of these two monsters," says Battell, " is called pongo in their language; and the less is called engeco. This pongo is exactly proportioned like a man; but he is more like a giant in stature; for he is very tall, and hath a man's face, hollow-eyed, with long hair upon his brows. His face and ears are without hair, and his hands also. His body is full of hair, but not very thick, and it is of a dunnish colour. He differeth not from a man but in his legs, for they have no calf. He goeth always upon his legs, $\mathrm{B}$ b 2 
and carreth his hands clasped on the nape of his neck when he goeth upon the ground. 'They sleep in the trees, and build shelters from the rain. They feed upon fruit that they find in the woods, and upon nuts; for they eat no kind of flesh. They cannot speak, and appear to have no more understanding than a beast. The people of the country, when they travel in the woods, make fires where they sleep in the night; and in the morning, when they are gone, the pongos will come and sit about the fire till it goeth out; for they have no understanding to lay the wood together, or any means to light it. They go many together, and often kill the negroes that travel in the woods. Many times they fall upon the elephants which come to feed where they be, and so beat them with their clubbed fists, and with pieces of wood, that they will run roaring away from them. Those pongos are seldom or never taken alive, because they are so strong that ten men cannot hold one of them; but yet they take many of their young ones with poisoned arrows. The young pongo hangeth on his mother's belly, with his hands fast clasped about her; so that, when the country people kill any of the females, they take the one which hangeth fast upon its mother, and, being thus domesticated and trained up from their infant state, become extremely familiar and tame, and are found useful in many employments about the house."

Purchas informs us, on the authority of a personal conversation with Battell, that a pongo on one occasion carried off a young negro, who lived for an entire season in the society of these animals ; that, on his return, the negro stated they had never injured him, but, on the contrary, were greatly delighted with his company; and that the females especially showed a great predilection for him, and not only brought him abundance of nuts and wild fruits, but carefully and courageously defended him from the attacks of serpents and beasts of prey.

With the exception of such information as has been drawn from the observance of one or two young individuals sent alive to Europe, our knowledge of this species has not increased. We have become aware of the inaccuracy and exagreration of previous statements, but have not ourselves succeeded in filling up the picture. It is indeed singular, that when the history of animals inhabiting New- 
Holland, or the most distant islands of the Indian Ocean, are annually receiving so much new and correct illustration, the most remarkable species of the brute creation, inhabiting a comparatively neighbouring country, should have remained for about 2000 years under the shade of an almost fabulous name, and that the "wild man of the woods" should express all we yet really know of the African orangoutang in the adult staie. .

Africa produces many other species of the monkey tribe. The promontory most familiar to the Mediterranean voyager, called Apes' Mountain, not far from the opposing point of Gibraltar, is so called from the occurrence of these animals ; and the rock of the last-named fortress is itself the only strong-hold which they possess in Europe. They do not, however, occur in desert countries, commonly so called ; that is, the open sandy plains of Africa are altogether unfitted for the dwellings of these pigmy people. Apes of all kinds are a sylvan race. Their structure being such as to render them unfit for the exercise of rapid movements, either on all-fours or in an upright position, the inclined and densely intermingled branches of trees are their favourite places of resort. Their feet in climbing being equally useful with their hands, great additional power and activity are thus derived. Among the shady and otherwise unpeopled arbours which skirt the banks of the yet mysterious rivers of Africa, they dwell in single pairs or in congregated troops, according to the instincts of each particular kind; and seated on the tops of ancient trees, or swinging from pendant boughs, they play their fantastic tricks, secure alike from the wily serpent during the day, and the panther which prowls by night.

The pigmy of the ancients is a small Ethiopian species, resembling the Barbary ape, but smaller in size, not much exceeding the dimensions of a cat. Its tribes were formerly alleged at certain seasons to wage a bloody war with cranes.

The callithrix, or green monkey (Simia Sabaa), is not unfrequently exhibited in menageries, where, however, its beautiful colour usually fades into a dingy olive. It occurs in various parts of Africa, both along the western and eastern shores. The name of callithrix, which signifies beautiful hair, was employed by Homer to denote the more ornamental 
colouring of the coat of various animals. It was applied by Greek authors, some centuries posterior to the time of Homer, to certain monkeys, and is now used specifically to distinguish the species in question. M. Adanson informs us that the woods of Podor, along the river Niger, are filled with green monkeys. He could discover them only by the branches which they cast down from the tops of the trees; for they were otherwise so silent, as well as nimble, that he could scarcely obtain a glimpse of them in their natural positions. After he had shot two or three, the rest became alarmed, and endeavoured to shelter themselves behind the trunks and larger branches. Some descended to the ground; but the greater number of those that remained unwounded, sprung with great activity from the top of one tree to another. "During this operation," says the traveller, "I continued to shoot, and in the space of twenty fathoms I killed twenty-three in less than an hour, and not one of them uttered the smallest cry, though they frequently assembled in troops, grinded their teeth, and assumed a threatening aspect, as if they meant to attack me."

The white-nosed monkey (Cercopithecus petaurista of Desmarets) inhabits the coast of Guinea. When taken young it is easily tamed, and is then exceedingly lively and diverting. The adult animals in the wild state are cunning and fierce, and aroid the vicinity of mankind.

The amount of species in this order of animals is so great, that, even confined as we are to those of a single continent, a volume would scarcely suffice for the most superficial sketch of their history, were we to include the whole of the African species. We must therefore be very brief in what remains to be told of one or two additional kinds. Next to the magot or Barbary ape, one of the best known in Europe is the mona or varied monkey. It is native to the northern parts of Africa, and appears to have been known to the Greeks under the name of kebos. This species is of an affectionate nature in confinement, and is more than usually susceptible of education. Some consider him synonymous with the Abyssinian ape described by Ludolphe, which that author saw in great troops turning over stones, with entomological zeal, in search of worms and insects.

It was probably a species allied to that last mentioned in 
its habits, of which an amusing though tragical account is given by Le Vaillant. In one of his excursions he killed a female monkey which carried a young one on her back. The young one continued to cling to her dead parent till they reached their evening quarters, and the assistance of a negro was even then required to disengage it. No sooner, however, did it feel itself alone than it darted towards a wooden block, on which hung the peruke of Le Vaillant's father. To this it clung most pertinaciously by its forepaws ; and such was the strength of this deceptive instinct, that it remained in the same position for about three weeks, all this time evidently mistaking the wig for its mother. It was fed from time to time with goats' milk, and at length emancipated itself voluntarily, by quitting the fostering care of the peruke. The confidence which it ere long assumed, and the amusing familiarity of its manners, soon rendered it the favourite of the family. The unsuspecting naturalist had however introduced a wolf in sheep's clothing into his dwelling; for one morning, on entering his chamber, the door of which he had imprudently left open, he beheld his young favourite making a hearty breakfast on a very noble collection of insects. In the first transports of his anger he resolved to strangle the monkey in his arms; but his rage immediately gave place to pity, when he perceived that the crime of its voracity had carried the punishment along with it. In eating the beeties, it had swallowed several of the pins on which they were transfixed. Its agony consequently became great, and all his efforts were unable to preserve its life.

Baboons are fully more characteristic of Africa, as a generic group, than any other of the quadrumanous order. With the exception of the dog-faced baboon (Cynocephalus hamadryas), a native of the environs of Mocha, and other eastern shores of the Red Sea, we are not acquainted with any species of the genus which is not of African origin. They are, without doubt, notwithstanding their approximation in some respects to the human form, the most disgusting of the brute creation. Perhaps it is this very resemblance which excites our dislike. In spite of their occasionally brilliant colouring, and the length and beauty of their fur, there is an expression of moral deformity in their aspect which is exceedingly revolting, and they seem pos 
sessed of all the most odious and degrading propensities of the most God-forsaken of the human race. No other species exhibit so strong a concentration of the animal propensities. They are the most sensual of the brute creation.

The strength of some baboons is enormous. By muscular energy alone, and without the assistance of their huge tusks, they will tear the strongest dog to pieces in a few minutes. During one of Mr. Burchell's hunting parties, two of his dogs were seized by baboons (Cercopithecus ursinus); one of them was killed on the spot by having his jugular artery bit through, and the other was severely disabled, and a part of his ribs laid bare. Fortunately, with all their fierceness, their propensities are not carnivorous, otherwise the most dreaded of the feline race would prove less formidable foes. In a state of nature they feed principally on roots and fruits, although the eggs and young of birds probably also form a part of their sustenance.

As in the present summary we are guided rather by zoological than geographical principles, with a view chiefly to avoid the repeated mention of the same animal, a necessity from which we could scarcely escape were we to trace successively the natural history of each African district, instead of that of the species or genera themselves in systematic progression,-we shall proceed to the next group in our scientific arrangements, that of the LEMURS.

This singular tribe of animals inhabits the great island of Madagascar, and the not distant island of Anjouan, one of the group of the Comora archipelago,-countries usually regarded as belonging to the African division of our globe. In common with apes and monkeys, they are quadrumanous animals, - that is, possessed of the power of prehension both with their fore and hind feet. They differ, however, among other characters, in having a rather long and pointed nail, instead of a flattened one, on the first finger of the hind foot.

The ring-tailed lemur ( $L$. catta, Linn.) is the most beautiful of the genus. Its motions are characterized by a great degree of elegant lightness : its manners are mild, and its nature very harmless. Its size is equal to that of a large cat, and its wool is extremely soft and fine. The tail is about twice the length of the whole body, and is marked 
by numerous rings of alternate white and black. In the wild state it is gregarious, travelling in small troops of thirty or forty. When taken young, it is easily tamed. It delights in sunshine; and in a state of domestication prefers the fireside to most other places. Its general attitude resembles that of a squirrel; and it feeds on fruits. In captivity it becomes more omnivorous, and shows no distaste to animal food. The voice of the ruffed lemur is remarkable for its extraordinary strength, which strikes with fear and astonishment those who hear it for the first time. It may be likened to that of the Beelzebub or howling monkey, which fills the woods of Guiana with its dreadful cries. The power of voice in both cases no doubt proceeds from a peculiar structure of the larynx.

Allied to the lemurs, and till lately generically classed with these animals, is the indri, which, according to Sonnerat, the natives of Madagascar domesticate and train up as we do the dog to the sports of the field. It is a large animal, measuring about three feet and a half in length; its prevailing colour is blackish, with the visage and lower part of the abdomen gray, and the rump white. It is distinguished by having no tail. Its voice resembles the crying of an infant, and its manners, like those of its congeners, are mild and docile.

The last of the quadrumanous tribe peculiar to Africa, which we shall take occasion to mention, ate the galagos. The Senegal galago is about the size of a common rat. They dwell on trees like monkeys and squirrels, are mild in their manners, and feed on insects, which they catch in their fore paws, and devour with great avidity. The great galago inhabits the eastern coast of Africa, and a species occurs in the island of Madagascar.

We now approach the more carnivorous tribes; and, passing over the genus Galeopithecus, the distribution of which is confined. to Asia and its islands, we enter upon the Vespertiliones, or great family of the bats, now divided into many genera. Of these the greater proportion belong to South America and the East Indies; so that our notice of the African species may be short, without being really much curtailed. Several species occur along the western shores; but the most remarkable is the great bat of Madagascar, described by Edwards, and regarded by some as 
synonymous with the vampyre. A vampyre is in many respects an imaginary monster, whose chief amusement consists in sucking the blood of sleeping persons. The name is connected with a superstition absurd in itself, though sufficiently fearful to such as believed in it, which prevailed in Poland and Hungary about the year 1732. According to this wild belief, certain individuals were supposed to rise from the grave and suck their friends and relations to death. Lord Byron has alluded to the fantasy in the following well-known lines :-

"But first, on earth as vampyre sent,

Thy corse shall from its tomb be rent:

Then ghastly haunt thy native place,

And suck the blood of all thy race;

There from thy daughter, sister, wife,

At midnight drain the stream of life;

Yet loathe the banquet which perforce

Must feed thy livid living corse :

Thy victims ere they yet expire

Shall know the demon for their sire,

As cursing thee, thou cursing them,

Thy flowers are withered on the stem.

But one that for thy crime must fall,

The youngest, most beloved of all,

Shall bless thee with a father's name-

That word shall wrap thy heart in flame !-

Yet must thou end thy task, and mark

Her cheek's last tinge, her eye's last spark,

And the last glassy glance must view

Which freezes o'er its lifeless blue;

Then with unhallowed hand shalt tear

The tresses of her yellow hair,

Of which in life a lock when shorn,

Affection's fondest pledge, was worn;

But now is borne away by thee,

Memorial of thine agony :

Wet with thine own best blood shall drip

Thy gnashing tooth and haggard lip;

Then stalking to thy sullen grave,

Go-and with Gouls and Afrits rave;

Till these in horror shrink away

From spectre more accursed than they '"

Some vague allegations of a somewhat similar nature (excepting the resurrectionary faculty) having been adduced against certain of the bat tribe, Linnæus named one of them Vespertilio vampyrus. The general colour of the body is deep reddish brown, brighter on the neck and shoulders. The teeth are large and shary; the wings 
black, and measuring several feet in extent, and the tail is wanting. This apparently formidable animal was supposed to perform its deadly operations by inserting its sharppointed tongue into the vein of a sleeping person, and in so delicate and peculiar a manner as to occasion no pain. The sleep of the victim was not even disturbed, and the bat, by the fanning motion of its wings, produced a delicious coolness around, which rendered repose the deeper, till the sufferer awoke in eternity.

-Whatever may be the case as regards the propensities of some of the South American species, of whose bloodsucking disposition Humboldt does not seem to doubt, it appears to be the opinion of naturalists that the vampyrebat of Linnæus is a frugivorous animal, of perfectly innocuous habits. According to Edwards, it is a native of Madagascar.

Among the smaller insectivorous quadrupeds, several kinds of shrew mice (Sorex) inhabit different quarters of Africa. The Cape shrew (S. Capensis) dwells in caverns, and occurs at the Cape of Good Hope.

The chrysoclore, or Cape mole, is remarkable for the brilliant metallic colours which adorn its fur. Its size is rather less than that of the common mole of Europe, and there is a resemblance to that species in its general form. The fore feet have only three claws, of which the exterior is the largest : the hind feet are furnished with five weaker claws. Its true country is the Cape of Good Hope, though naturalists have been led into error regarding its locality by a false indication in the Thesaurus of Seba, by whom Siberia is assigned as its native region.

The tenrec (Setiger of Cuvier), an animal formerly classed with the hedgehogs, inhabits the island of Madagascar, and may be mentioned as the only known instance of a hibernating species indigenous to a warm climate. It burrows in the ground, and remains torpid for about three months in the year. It usually lies concealed during the day, and ventures abroad after sunset in search of fruits and herbs. Its body is generally very fat, and is eaten by the natives of Madagascar. There are several species of the genus, all confined to that island, where, from their grunting voices, they are called ground-hogs. One of these C c 
(S. ecaudatus) is defended by spinous projections, and is known to Europeans under the name of the pig-porcupine.

The ratel, or honey-eater (Mellivora Capensis), is peculiar to the southern extremity of this continent. The general colour of the upper surface of the body is gray - of the under, black, -an unusual contrast, as the inferior parts of the fur of most animals are paler than those of the dorsal region. Its fore claws are very long. It lives on honey, and digs up the nests of wild bees from the deserted burrows of different animals. It is said to watch the flight and motions of a species of cuckoo (the Cuculus indicator) which preys on bees. The Hottentots indeed follow the same guide, and are also alleged to discover wild honey lodged in trees, by observing the bark gnawed around the base by the spiteful ratel, which cannot climb.

We are not acquainted with any animal of the otter kind, strictly so called, inhabiting Africa; although Europe, Asia, and America are well supplied with several sorts. The nearest approach, among the African forms of animal life, is presented by the Aonyx Delalandi, remarkable for its feet being either without nails, or for the existence of these appendages in a merely rudimentary state on one or two toes of the hind feet. It is named Lutra inunguis by some naturalists, on account of that peculiarity. This animal measures about three feet in length, exclusive of the tail, which extends about ten inches; the fur is soft and thick, of a chestnut-brown colour, paler on the flanks, with a mixture of gray about the head. It preys on fish and crustacea, and inhabits the salt pools along the borders of the sea in the vicinity of the Cape.

Canine animals are very generally distributed over the surface of our globe. Under that appellation naturalists include not only domestic dogs, and all their interminable varieties, but wolves, foxes, and jackals. Wolves are characteristic of the temperate and northern parts of Eurcpe and America. Foxes have a somewhat similar distribution, but are more extended in a southern direction; while jackals abound in most of the warmer regions of the Old World, but, unlike the other two, are unknown in America. There are three species of jackall. The Asiatic species (Canis aureus) characteristic of, but not peculiar to the continent of Asia, is the most widely spread. It occurs 
over a great extent of country from India to Palestine, and from Egypt and Barbary along the shores and through the central deserts of Africa to the Cape of Good Hope. This is the species commonly called the lion's provider. It hunts in packs ; and the king of beasts, when roused from his slumbers by the yells of these creatures in pursuit of prey, probably follows the hue and cry, and ere long comes in for his share of slaughtered deer or antelope. Tho Cape jackall, commonly so called (Canis mesomelanis), resembles a fox, and is characterized by a triangular mark of blackish gray upon the back, broader at the shoulders, and finishing in a point at the origin of the tail. It inhabits the Cape of Good Hope. Another species (C. anthus) is found in Senegal.

Intermediate between the dogs and hyenas may be placed a curious African animal, long known to the Cape colonists by the name of wild dog. "In the morning," says Mr. Burchell, "Philip returned with the oxen; but reported that, in consequence of Abram Abram's neglecting on the night before to seture them as usual in the cattle-pound, the wilde honden (will dogs) had bitten off the tails of three. One had only lost the brush, but the others were deprived of the whole." This species hunts in regular packs, both during the night and day; and it is so rapid in its movements that none but the fleetest animals can ensure their safety. Sheep fall an easy sacrifice, though the larger cattle are seldom attacked, except stealthily from behind for the sake of snapping off their tails. The want of a tail, in a warm country swarning with flies, is a source of the most serious annoyance to any quadruped; and the visits of this hyenadog are therefore much dreaded and suitably guarded against. The animal in question is of a more slender form than either the striped or the spotted hycna. Its general colour is a sandy bay or ochrey yellow, shaded with darker hairs; and the whole body is blotched and brindled with black, with here and there a spot of white. Mr. Burchell's specimen, which he kept for thirteen months chained up in a stable-yard, was extremely ferocious in its nature. It became at length in some degree attached to a common dog, with which it used to gambol; but even the keeper by whom it was fed never ventured to touch it with his hand.

Africa is the country of hyenas. The spotted species 
(H. Capensis, Desm., Canis crocuta, Linn.) is peculiar to that continent, and abounds in its southern extremity. The striped species (H. vulgaris, Desm., C. hyana, Linn.) is more characteristic of the northern districts. It is frequent in Egypt, Abyssinia, and Nubia, and extends into Syria and Persia. It is a risgusting and troublesome animal wherever it occurs. It haunts the suburbs, and even penetrates into the streets of some eastern cities after sunset, preying on offal and stealing the remains of dead carcasses, which it prefers to living prey. One of them robbed Bruce the traveller of some pounds of tallow candles, by entering his tent under cloud of night.

The animals called civets are found both in Asia and Africa.

We now enter upon the consideration of the feline tribes, the most ferocious and bloodthirsty of the bruie creation. Though the tiger is unknown to Africa, the lion, the king of beasts, here reigns with undisputed sway, anc is not only more numerous, but also more magnificent in his proporions, than in any other country. Celebrated fom the most :emote antiquity for his courage and magnanimity, this iruly majestic creature has long been held as srmbolical of joldness; and his countenance and general jearing cer:ainly imbody our liveliest conceptions of warlike grandeur, sombined with a certain dignity of aspect not unbefitting jis assumption of regal sway. The painter, the poet, the sculptor, and the rhetorician have alike tried in vain to depict the terrors of this grisly king.

The southern parts of Africa present a variety of the iion, of which the mane is nearly black. The Barbary lions are brown, with a very thick mane covering the neck and shoulders of the male. Those of Senegal are of a more yellow hue, with thinner manes. It is unnecessary to enter into any minute descriptive details of this familiarly-known animal.

The ancients sculptured a lion without a mane, which some modern writers regard as an extinct, others as a fictitious species. It occurs on the hieroglyphical monuments of Upper Egypt ; and a curious confirmation of its existence has been received from Nubia, where, it is alleged, a very large and maneless lion has been recently discovered. 
Although the life of the lion is limited by Buffon to about twenty years, there is no doubt that it usually attains to a much greater age.' Pompey, who died in the year 1760, had been confined in the Tower above seventy years, and another was known to have died there at the age of sixtythree. Sparrman and others have impugned the character of this noble animal, and alleged that a greater degree of timidity exists in his constitution than is compatible with courage. It may, however, be given as a piece of safe advice to the inexperienced emigrant, not to place too much confidence in the cowardice of lions.

The geographical boundaries of the lion appear to have been greatly circumscribed within these last two thousand years. Even where it still exists in comparative abundance, it is an animal of rare occurrence ; and, from many districts where it once abounded, it has now entirely disappeared. According to Herodotus, they were once sufficiently common both in Thrace and Macedonia; and they are known to have formerly abounded in Asia, from the shores of Syria to the banks of the Ganges and the Oxus. By what means the Romans contrived to assemble those vast troops which they sometimes exhibited at their games, it would now be difficult to determine; but we know that Sylla fought together one hundred males, and Pompey three hundred and fifteen. Those of Sylla were sent by Bpochus, king of Mauritania; but at present a brace of lions would be thoug', it a very princely. gift from any of the Moorish kingdoms. Even in the time of Probus, about the middle of the third century, one hundred male lions, and the like number of females, were exhibited. We may however presume that even prior to this period they were considered as rather scarce, as the hunting of the lion was forbidden to the vulgar, lest the supply required for the circus should be diminished. This law was abrogated in the time of Honorius ; though their entire destruction in so many districts was probably not achieved till after the introduction and general use of firearms.

As the northern parts of Africa are known to have been thickly peopled during the time in which lions so greatly abounded there, we may hence infer that the co-existence of the larger carnivorous animals along with the human. race, is not, as many philosophers have imagined, altogether C c 2 
incompatible. They imagine themselves to have seen, in the limited actual number of lions and tigers, a guarantee of nature, as it has been called, for our preservation, and that of animal life, throughout the world. But the truth is, as Azara and others have remarked, that these tremendous creatures rarely attack the human race, except in cases of great necessity, or in self-defence.

Africa produces two other fine feline animals, the panther and the leopard, on the history of which we shall not at present enter. Although they are both well known, and frequently exhibited in our menageries, considerable confusion still exists regarding their natural history and localities in the works of zoological writers. Lynxes also occur in Africa.

Passing over the seals and other amphibious quadrupeds, of which we know of none characteristic of this continent, we come to the order called Glires by naturalists, more familiarly named gnawers. Of these the first and most beautiful tribe which presents itself is that of the squirrels.

Few of these inhabit the country now under discussion. The forests of America are their familiar homes, and many species also occur in India and the Asiatic islands. But the African woods are likewise, though to a more limited extent, enlivened by the gambols of these graceful creatures.

The palm-squirrel is somewhat larger than our British species. It inhabits the warmer regions of A sia and Africa, and dwells on palm-trees. The Madagascar squirrel is found in the island of that name ; and the Gingi squirrel, so called from its Indian locality, is also alleged to occur at the Cape of Good Hope.

Of the marmot tribe, numerous in the north of Asia and America, and represented in Europe by the Alpine species, so famous for its long-continued winter sleep, Africa produces very few examples. The only one indeed with which we are acquainted is the marmot gundi (Arctomys gundi of Gmelin), a species resembling the European kind in its form, but characterized by having only four toes to each foot. The size is that of a rabbit ; its colour reddish ; its ears very short, but broad in their openings ; and its locality Mount Atlas. 
We may here notice the genus Bathyergus, peculiar to the south of Africa. The sand mole (B. maritimus), as the larger species is usually called, occurs in abundance along the sandy shores of the Cape of Good Hope, where it frequently renders the ground hollow by its excavations, and consequently inconvenient, if not dangerous, to horsemen. It feeds principally on bulbous roots, such as those of ixiæ and antholyzæ. This animal is of the size of a rabbit. It runs awkwardly on the surface, but burrows and makes its way under ground with great facility. The other species is known by the name of Cape rat (B. Capensis). Its habits are similar to those of the species just mentioned, but it is considerably smaller. It is destructive to gardens and ornamented pleasure grounds, by throwing up the earth, like our European mole, in the course of its subterranean excavations. A third species has been lately described under the name of Bathyergus Hottentotus, by MM. Lesson and Garnot.

Another genus found in Africa, though not peculiar to that continent, is the Dipus or gerboa. The Egyptian gerboa inhabits the environs of Memphis and the Pyramids. This species appears to have been known to the ancients under the name of two-footed mouse. It is a beautiful little animal, remarkable for its extended tail and the great length of its hind legs. It is hunted with greyhounds by the Arabs of the kingdom of Tripoli. The Prince of Tunis presented Bruce with a trained greyhound, which afforded him excellent sport in that way.

The Cape gerboa (D. Cafer), now referred by naturalists to the genus Helamys, is the largest of the tribe. It measures one foot two inches from nose to tail, and the tail is fifteen inches long. This species is remarkable for its great strength and activity. It will spring from twenty to thirty feet at a single bound, and inhabits the mountainous countries to the north of the Cape of Good Hope. It is called the springen haas, or jumping hare, by the Dutch colonists.

Rats and mice, like many other domestic nuisances, are now very generally distributed over the globe. Wherever European nations have colonized, these small but adventurous creatures have accompanied the merchant or the 
mariner ; and from the forlorn settlements of the fur traders of North America to the populous cities of the south of Asia, their furtive habits of destruction are the source of equal annoyance. The common brown rat (Mus decumanus) is a native of India, and only made its appearance among the western nations of Europe from the beginning to the middle of last century. The original country of its predecessor, the black rat (M. rattus), if not unknown, is at least doubtful. It is not mentioned by any ancient writer, and appears to have been introduced into Europe during the middle ages. Within the last half century it has been nearly extirpated from most of the great European cities by its larger and more powerful rival.

Africa produces several species of murine animals, not hitherto recognised in any other region of the earth. A beautiful small,species, discovered and described by Sparrman, is native to the forest countries of the Slangen River, eastward from the Cape of Good Hope. It appears, however, to be nearly allied to the genus arvicola, which includes the water-rats.

The dormice (genus Myoxus) are also represented in Africa by a species communicated by Pennant to Sir Joseph Banks, and said to have been discovered among the mountains of Sneuwberg, above 800 miles beyond the Cape. Its size is that of a squirrel; but its shape is broader and more flattened. . Nothing is known of its habits or history, or whether, as Martial supposed of another species of dormouse, it not only hibernates but is fattened by repose, -

Tota mihi dormitur hiems; et pinguior jllo

Tempore sum quo me nil nisi somnus alit.

We have seen, even in the course of the slight view which we have hitherto taken of the quadrupeds of Africa, that some genera are entirely restricted to that continent, while others are distributed likewise over Europe and Asía. The genus Hystrix, which contains the porcupines, as formerly constituted was remarkable for its dispersion over all the four quarters of the globe ; but, as the American species are classed by recent systematists in a separate genus, the true porcupines may be said to be confined to the Old World.

The common porcupine (Hystrix dorsata) inhabits two 
very distant points of Africa, Barbary and the Cape of Good Hope. It is also found in India, Persia, Greece, Italy, and Sicily. Mr. Brydone informs us, in his Tour, that it is frequent in that island in the district of Baiae, and that he killed several during a shooting party on the Monte Barbaro. He dined upon his game, but found it luscious and soon palling upon the appetite. The singular aspect of this animal seems to have attracted the attention of the lovers of nature at a very early period, and many fabulous properties were added to the true character of a creature in itself sufficiently curious. It was said to possess the power of darting its quills at pleasure with great force, and to a considerable distance, against its enemies. There is no doubt, that when agitated either by fear or anger, it bristles up its quills, rattles them against each other as an Indian warrior might his quiver full of arrows, and that in this temporary agitation a quill may be occasionally thrown out, and might even settle itself in the body of an adversary; but they are essentially fixed, though not immoveable organs, and can no more be parted with in self-defence than the spines of the hedgehog. Claudian, however, observes, that the porcupine is himself at once the bow, the quiver, and the arrow, which he employs against the hunters,-

Ecce, brevis propriis munitur bestia telis,

Externam nec quærit opem, fert omnia secum,

Se pharetra, sese jaculo, sese utitur arcu !

The porcupine feeds chiefly on roots, fruits, and other vegetable produce. It dwells in subterranean retreats, and comes abroad more frequently during the night than the day.

We come now to the hares and rabbits, a genus widely distributed from the shores of Hudson's Bay to the Straits of Magellan, and from Siberia to Bengal. The common rabbit (Lepus cuniculus) is supposed to have been originally introduced from Africa into Spain, and to have been extended from the latter country over the rest of Europe.

The Egyptian hare (Lepus Egyptius) occurs also at the Cape of Good Hope. The ears and hind legs are proportionally longer than those of the European species. The anterior legs appear to have only four toes, owing to the thumb or inner toe being very small. Its fur, though not 
entirely similar, does not greatly differ from that of our own species. Those from South A frica are of large size.

A small species ( $L$. arenarius) about one-fourth less than a rabbit, was lately discovered by $M$. Delalande, inhabiting sandy districts in the country of the Hottentots.

The singular family of the armadilloes would require no mention in our present sketch, were it not that the laborious though inaccurate Seba has represented one of them under the name of the $\Delta$ frican armadillo. Suffice it to say, that no species of the genus is found elsewhere than in America.

An animal peculiar to Africa is the Cape ant-eater (Orycteropus Capensis). The ant-eaters, properly so called (genus Myrmecophaga), are peculiar to America; so that the species now under consideration may be regarded merely as their African representative. It is an animal of large dimensions, measuring between three and four feet in length, exclusive of the tail, which is nearly two feet long. Its habits are nocturnal and subterraneous, and its food consists of ants and termites, which it seizes with its long and glutinous tongue, after having disarranged their dwellings with its paws. It occurs in the neighbourhood of the Cape of Good Hope.

The animal kingdom scarcely presents us with quadrupeds of a more marked and peculiar aspect than the pangolins or manis tribe. Instead of hair, they are covered with a scaly armour, consisting of numerous leaf-like plates, lying over each other after the manner of tiles; and their slender cylindrical bodies and lengthened tails give them so much the aspect of reptiles, that they are very generally known under the name of scaly lizards. They are harmless animals, feeding like the ant-eaters on insects, particularly ants, which they collect by thrusting their long tongues into the dwellings of these industrious creatures. They inhabit both India and Africa. The species called, par excellence, the long-tailed (Manis tetradactyla, Linn.), inhabits Senegal and the coast of Guinea.

We now arrive at the pachydermatous, or thick-skinned animals, corresponding to the order BELLU se of Linnæus. 
In this division are included the elephant, the tapir, the rhinoceros, the hyrax, or Cape marmot, the pecaris, the babyroussa, the wild boar, the African boar, the hippopotamus, and the horse.

The most gigantic of all living terrestrial animals, the elephant, combines superhuman strength with almost human wisdom, in a manner otherwise unequalled among the brute creation. Many instances are on record of its retentive memory, its grateful and affectionate disposition, and its general intelligence as a discriminating, if not 'reflecting creature. From the earliest ages its stupendous size and unexampled sagacity have formed a theme of wonder and admiration to mankind. Elephants in the wild state are gregarious and herbivorous. They are naturally averse to the extremes of heat and cold; and, although inhabitants of some of the most sultry regions of the earth, they shelter themselves from the overpowering heat of the midday sun in the comparative coolness of those umbrageous forests which, both in Africa and Asia, are their chosen places of abode.

Of the Asiatic elephants, the Ceylonese are the most celebrated. Indeed, the torrid zone seems the most favourable for the production of the largest races. Along the coast of Malabar, elephants occur as far north as the territories of Coorgah Rajah ; but these, according to Mr. Corse (Scott), are inferior to the breed from Ceylon.

The African elephant is easily distinguished from the Asiatic, by his rounder head, his convex forehead, his enormous ears, and the lozenge-marked surface of his grinders. His tusks are also longer, and those of his female are equally great; whereas the female of the Asiatic elephant has very small tusks. He inhabits a wide extent of Africa, from Senegal to the Cape, and abounds in the forests of the interior. The African elephant has not been rendered serviceable to man, like that of Asia. This, however, arises from no defect in the docility of the animal, but rather from a difference in the social and political conditions of the human tribes of Africa, and their inferior civilization. The ancient Carthaginians made use of elephants, which there is no reason to suppose were otherwise than of African origin, in like manner as the Asiatic variety was used by Porus and the Indian kings. In modern times, the inven- 
tion and extended use of firearms have rendered the warlike services of these huge creatures of comparatively little avail ; but their great strength and sobriety of conduct render them highly efficient, indeed indispensable, in eastern countries as beasts of burden, and as accessaries in the sports of the field.

It is not yet clearly ascertained whether the elephants of the eastern shores of Africa are the same as those of the interior and western districts, or whether they do not exhibit a closer approximation to the Asiatic species. We shall conclude by observing that the size of the elephant has been much exaggerated. Dr. Hill, for example, asserts, that, when full grown, it is from seventeen to twenty feet high. One-half of the latter height is probably nearer the truth, even for an individual of more than usual size, and twelve feet may be stated as the extreme dimensions.

Second in size, though widely distant in sense, is the rhinoceros, an animal of a sour and stubborn disposition, and in every way less trustworthy than the elephant. Of this genus there are several species, two of which (if $R$. Burchellii is entitled to specific distinction) inhabit Africa. The others are native to India, and the great islands of Java and Sumatra. The African species $(R$. Africanus) is armed with a couple of horns ; its coat is not distinguished by voluminous folds, and it wants the incisive teeth. The sense of sight is said to be rather defective in the rhinoceros: those of smell nnd hearing are acute.

Another animal, characteristic of, though not entirely peculiar to Africa, is the hyrax or Cape marmot. This species is supposed by some biblical annotators to be the cony of the Scriptures. It inhabits the rocky territories of many parts of Africa, and occurs, with little variation in its external aspect, in Syria. With the exception of the horns, it bears a strong resemblance to a-rhinoceros in miniature.

The Ethiopian hog (Phascocharus Africanus) is a fierce and savage animal, allied to the wild boar in its habits, but distinguished by a pair of large lobes or wattles placed beneath the eyes. The tusks of the upper jaw bend upwards in a semicircular manner towards the forehead. When attacked, it is apt to become furious, and, rushing on its 
adversary with great force and swiftness, inflicts the most desperate, and sometimes fatal wounds. It inhabits a wide extent of country along the western side of Africa, from Senegal to the Cape ; and it also occurs specifically the same in Ethiopia. A new species of this genus has been recently discovered in the north of Africa by M. Rüppell. It is named Phascochorus barbatus. The ascertainment of the latter animal is a proof, among many others which might be adduced, of the impropriety of denominating a species from the continent which it inhabits. Few species are so isolated in the animal kingdom as to exist alone over a great tract of country, without claiming kindred with any other; and we may fairly infer, à priori, that when one of a genus is discovered, a second or a third will ere long make its appearance. When this happens, such specific names as Africanus, Americanus, \&c. cease to be of a discriminating or exclusive nature, and consequently lose their value.

Next to the elephant and rhinoceros, perhaps the most bulky land animal with which naturalists are acquainted, is the hippopotamus or river-horse. It is peculiar to Africa, and inhabits the fresh waters of that continent. It formerly existed in Lower Egypt, but has long since disappeared from that district. Mr. Bruce makes mention of hippopotami as existing in the Lake Tzana, exceeding twenty feet in length. It would be hard to limit the growth of this naturally gigantic species ; but the largest ever killed by $\mathrm{Co}$ lonel Gordon, an experienced hippopotamist, did not exceed eleven feet eight inches. M. Desmoulins regards the species of Senegal as differing from those of the more southern parts of Africa. These animals are chiefly valuable on account of their ivory tusks, which, being harder than those of elephants, and not so subject to turn yellow, are much esteemed by dentists. Their hides are formed into bucklers by several of the African tribes.

We now arrive at the genus Equus, or horse tribe, which consists of six species, three of which are peculiar to Africa, viz. the mountain-zebra ( $E$. zcbra, Linn., E. montanus, Burchell), the zebra of the plains ( $E$. zcbra, Burchell), and the quagga, (E. quagga, Linn.) Neither the ass nor the common horse are aboriginal inhabitants of this continent. D d 
The aspect of the zebra is too familiarly known to require description. It is one of the most fancifully adorned of all known quadrupeds; but the beauty of its external appearance is its chief merit, as its disposition is wayward and capricious in the extreme. With the exception of one or two instances, in which persevering individuals have succeeded in subduing the stubbornness of its nature, it has not been rendered subservient to the purposes of the human race. It is a mountain-animal, called daur by the Hottentots, and is scarcely ever seen on the plains.

The zebra of the plains, although only recently characterized as a distinct kind, is in fact a better known and more abundant species than the other. It is chiefly distinguished by the want of rings upon the legs. "I stopped," says Mr. Burchell, " to examine these zebras with my pocket telescope: they were the most beautifully marked animals I had ever seen; their clean sleek limbs glittered in the sun, and the brightness and regularity of their striped coat presented a picture of extraordinary beauty, in which probably they are not surpassed by any quadruped with which we are at present acquainted. It is indeed equalled in this particular by the dauw, whose stripes are more defined and regular, but which do not offer to the eye so lively a colouring."

The quagga is more nearly allied to the zebra of the plains than to that of the mountains. It lives in troops in the neighbourhood of the Cape, and, in common with the zebra, is frequently found in company with ostriches. The wary disposition of these birds, and their great quickness of sight, are supposed to be serviceable to the congregated group in warning them of the approach of their enemies.

The next great tribe of animals which falls under our consideration, is that of the ruminating class (order PECoR., Jinn.); and of that tribe the most important member, and the most influential on the destinies of Africa, is the camel, or "ship of the desert," as it is beautifully called in the figurative language of the Arabs. "Of all animals," says Buffon, "the camel is the most ancient, the completest, and most laborious slave. $\mathrm{He}$ is the most ancient slare, because he inhabits those climates where men were first polished. He is the most complete slave, because in the other species of domestic animals, as the horse, the dog, the ox, the sheep, 
the hog, \&cc. we still find individuals in a state of nature, and which have not submitted to man. But the whole species of the camel is enslaved; for none of them exist in their primitive state of liberty and independence. Lastly, he is the most laborious slave, because he has never been nourished for pomp, like most horses, nor for amusement, like most dogs, nor for the use of the table, like the ox, the hog, and the sheep; because he has always been made a beast of burden, whom men have never taken the trouble of yoking in machines, but have regarded the body of the animal as a living carriage, which they may load or overload, even during sleep ; for when pressed, the load is sometimes not taken off, but the animal lies down under it, with his legs folded, and his body resting on his stomach."

There are two species of camel. The Bactrian species, or camel properly so called (Camelus Bactriamus), is characterized by a couple of humps, - one on the rump, and another above the shoulders. It is an Asiatic animal, and is said still to roam wild in the desert of Shamo, on the frontiers of China. It is capable of being acclirnated, without much difficulty, in comparatively northern countries, and was introduced into Tuscany by the Grand Duke Leopold, where it stil! breeds in the maremmas of the Pisan territory. It has, however, neither spread over the country, nor become at all extensively useful for the general purposes of rural labour. This is chiefly attributed to the improvident calculations of the minister Salviati, who, on their first introduction demanded about a thousand francs a-piece from such as inclined to purchase these animals for the sake of extending the breed. They are frequently seen in the streets of Pisa, carrying firewood, or other articles of domestic consumption, from the present Grand Duke's farms. It is this species which is employed in Thibet and 'Turkistan.

The other species of camel (C.dromedarius) has only a single hump on its back. It has spread from Arabia all over the northern parts of Africa, and has long been essential to the commerce of those dry and desert regions. It is also found in Syria, Persia, \&c., and was known under the name of Arabian camel to the ancient writers. The term

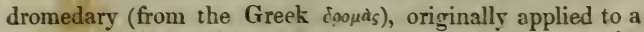
variety of this species, remarkable for its swiftness, as the 
name imports, is now for the most part bestowed on the species itself.

"To the wild Arab of the desert, the camel is all that his necessities require. He feeds on the flesh, drinks the milk, makes clothes and tents of the hair; belts, sandals, saddles, and buckets of the hide; he conveys himself and family on his back, makes his pillow of his side, and his shelter of him against the whirlwind of sand. Couched in a circle around him, his camels form a fence, and in battle an intrenchment behind which his family and property are obstinately, and often successfully defended. All these advantages are a necessary result of the constitutional faculties and structure of the camel when residing in the locality assigned him by nature : under another atmosphere, his qualifications become less important, and his conformation less applicable. In Tartary and Southern Russia, where the Bactrian species (longer of body and shorter of limb than the Arabian) is harnessed to wheel-carriages, and even to the plough, the elevation of his shoulders evidently produces a waste of strength; and, in a country where herbage and water are proportionally abundant, his sobriety is not required. If the camel is transferred to rocky and mountainous regions, his feet soon wear, and he ascends and descends with great awkwardness. If he be brought into temperate regions, the frequent mud, and above all, the thawed snows, soften his feet, and he is unable to work; as is at least partially experienced in Central and Northern Asia, notwithstanding that the Bactrian camel, again provided by nature for his particular locality, has soles of greater hardness than the Arabian, and the dissolution of the snow is excessively rapid when once begun."-Griffith's Animal Kingdom, vol. iv. p. 40.

The ancient authors do not seem to take notice of the camel as an inhabitant of Northern Africa. It is, however, mentioned in Genesis (chap. xii. ver. 16) as among the gifts bestowed by Pharaoh on Abram, and must therefore have been well known on the banks of the Nile at a period anterior to the oldest of the Greek or Roman writers. It has indeed been remarked as a singular circumstance, that the Romans, who carried on such frequent wars in Africa, should not have thought of mentioning these animals, till Procopius noticed camel-riding Moors in arms against Solomon, 
the lieutenant of Belisarius. Their uses in modern times are so well known, and all books of African travel are so frequent in their description of these docile beasts of burden that we deem it unnecessary to dwell any longer on the subject.

Very few animals of the deer kind, properly so called, are found in Africa. The red deer, however (Cervas elaphrus), one of the noblest of the tribe, and the most stately.of all the wild animals still indigenous to Britain, occurs in some of its northern quarters. But to these it was not improbably imported, at some unknown period, from Europe.

Before proceeding to the more abundant family of the antelopes, of which Africa is the great emporium, we shall mention, as a species entirely peculiar to this continent, the giraffe or camelopard, the tallest and, in every other respect, one of the most singular of quadrupeds. Its appearance is too familiar to our readers to require description. We shall merely state that it is a timid and gentle animal, feeding principally on the leaves of trees (especially those of the genus Mimosa), and inhabiting the plains of Central and Southern Africa. Its gatt, or mode of progression, is described as extraordinary by Mr. Lichtenstein. "We had scarcely travelled an hour when the Hottentots called our attention to some object on a hill not far off on the left hand, which seemed to move. The head of something appeared almost immediately after, feeding on the other side of the hill, and it was concluded that it must be that of a very large animal. This was confirmed, when after going scarcely a hundred steps farther, two tall swan-necked giraffes stood almost directly before us. Our transports were indescribable, particularly as the creatures themselves did not perceive us, and therefore gave us full time to examine them, and to prepare for an earnest and serious chase. The one was smaller and of a paler colour than the other, which Vischer immediately pronounced to be a colt, the child of the larger. Our horses were saddled, and our guns loaded in an instant, when the chase commenced. Since all the wild animals of Africa run against the wind, so that we were pretty well assured which way the course of these objects of our ardent wishes would be directed, Vischer, as the most experienced hunter, separated himself from us, and D d 2 
by a circuit took the animals in front, that he might stop their way, while I was to attack them in the rear. I had almost got within shot of them when they perceived me, and began to fly in the direction we expected. But their flight was so beyond all idea extraordinary, that, between laughter, astonishment, and delight, I almost forgot my designs upon the harmless creatures' lives. From the extravagant disproportion between the height of the fore to that of the hinder parts, and of the height to the length of the animal, great obstacles are presented to its moving with any degree of swiftness. When Le Vaillant asserts that he has seen the giraffe trot, he spares me any farther trouble in proving that this animal never presented itself alive before him.* How in the world should an animal, so disproportioned in height before and behind, trot? The giraffe can only gallop, as I can affirm from my own experience, having seen between forty and fifty at different times, both in their slow and hasty movement, for they only stop when they are feeding quietly. But this gallop is so heavy and unwieldy, and seems performed with so much labour, that in a distance of more than a hundred paces, comparing the ground cleared with the size of the animal and of the surrounding objects, it might almost be said that a man goes faster on foot. The heaviness of the movement is only compensated by the length of the steps, each one of which clears, on a moderate computation, from twelve to sixteen feet." A tolerably good horse overtakes the giraffe without difficulty, especially over rising ground.

Camelopards were known to the Romans, and were exhibited in the Circæan Games by Cæsar the dictator. The Emperor Gordian afterward exhibited ten at a single show ; and tolerably accurate figures of this animal, both in a browsing and grazing attitude, have been handed down by the Prænestine pavement. During the darker ages, and for some centuries after the revival of learning, it seems to have remained unknown to Europeans ; but, about the middle of the sixteenth century, the emperor of Germany, Fre-

* It would be more proper, and equally logical, rather to infer that Le Vaillant misapplied the term which he made use of to designate the movements of the camelopard, thar that he imagined himself to have seen an animal alive which had never presented itself to him in that condition.-ED. 
dericus Enobarbus, received one from the sultan of Babylon. Lorenzo de Medicis was also presented with a live camelopard by the bey of Tunis; and in our own times they have been received by the kings both of France and England from the (late) dey of Algiers.

Africa is the country of antelopes. These creatures are the most lively, graceful, and beautifully proportioned of the brute creation. Wherever known, they have attracted the attention and admiration of mankind from the earliest ages ; and the beauty of their dark and lustrous eyes affords a frequent theme to the poetical imaginings of the eastern poets. Their names are of frequent occurrence in the most ancient of the eastern mythologies, and their figures occur among the oldest of the astronomical symbols. Naturalists are more or less acquainted with about fifty species, the greater proportion of which are peculiar to the African continent.

The blue antelope (Antilope leucophaa), formerly met with in the Cape colony, is now so rare in South Africa, that no specimen has been killed there since the year 1799. Its history and manners are little known. The roan antelope ( $\boldsymbol{A}$. equina) is a very large animal, measuring nearly eight feet in length. It was found by Mr. Burchell among the mountainous plains in the vicinity of Lattakoo. The Caffrarian $\operatorname{oryx}(A \cdot \operatorname{ory} x)$ is an animal equally remarkable for the vigour as the beauty of its form. It inhabits elevated forests and the rocky regions of Southern Africa, and is exceedingly fierce during the rutting season, especially when wounded. A friend of Major Smith's having fired at one of these antelopes, it immediately turned upon his dogs, and transfixed one of them upon the spot. They afford the best venison of any of the species found in the south of Africa. The small white buffalo mentioned by Captain Lyon as occurring in the Great Desert south of Tunis, was no doubt a species of oryx. Another animal of very showy aspect belonging to this tribe is the addax, recently transmitted from Nubia by M. Rüppell. They reside in pairs on the barren deserts, and, extending over the whole Sahara, are found as far west as Senegal. The white-faced antelope ( $A . p y$ garga) is inferior in size to the stag of Europe. According to Major Smith, this species does not seem to be known in 
Central Africa. It is found in the regions which border the colony of the Cape, and is called blessbock by the Dutch. In manners it resembles the gnu, and lives in small families of seven or eight.

The springer antelope (A. euchon) is named springbock by the Dutch. It inhabits the plains of Southern and Central Africa, and assembles in vast flocks during its migratory movements. "These migrations, which are said to take place in their most numerous form only at the intervals of several years, appear to come from the north-east, and in masses of many thousands, devouring, like locusts, every green herb. The lion has been seen to migrate, and walk in the midst of the compressed phalanx, with only as much space between him and his victims as the fears of those immediately around could procure by pressing outwards. The foremost of these vast columns are fat, and the rear exceedingly lean, while the direction continues one way; but with the change of the monsoon, when they return towards the north, the rear become the leaders, fattening in their turn, and leaving the others to starve, and to be devoured by the numerous enemies who follow their march. At all times when impelled by fear, either of the hunter or the beast of prey darting among the flock, but principally when the herds are assembled in countless multitudes, so that an alarm cannot spread rapidly and open the means of flight, they are pressed against each other, and their anxiety to escape impels them to bound up in the air, showing, at the same time, the white spot on the croup dilated by the effort, and closing again in their descent, and producing that beautiful effect from which they have obtained the name of Springer and Showy-bock."-Griffith's Animal Kingdom, vol. iv. p. 209.

The kevel $(A$. kevella $)$ is nearly all ied to the dorcas, but does not appear to occur to the north of the Atlas, with the exception, perhaps, of the western coast of Morocco. In Central Africa, across the banks of the Congo, and southwards as far as the country of the Caffres, it forms numerous flocks. The pallah (A. melampus) is a beautiful species, mentioned by Lichtenstein. It is described as a model of elegance and vigour, and is a native of Caffraria, especially the Boshuana country. It never appears to the south of the Koorges Valley. The klipspringer (A. orea- 
Eragus) was formerly very abundant near the Cape, but is now rare, except in the interior of the country. They dwell among rocky precipices, and spring from cliff to cliff with surprising strength and agility. The steenbock (A. rupestris) likewise dwells among the rocks. It is found near Algoa Bay, but is now rare in the Cape colony. The vlackti steenbock ( $A$.rufescens) is among the most beautiful of the smaller antelopes of Africa. The name of vlackti is bestowed upon it, in consequence of its inhabiting the plains or open country. The bush-antelope ( $A$. silvicaltrix) is found at Sierra Leone, where it is called the bush-goat. It usually quits its cover in search of food about sunrise. The four-tufted antelope ( $A$. quadriscopa) is a native of Senegal. The duicker bock (A. mergens) is a timid species, fearful of thunder and other unaccustomed sounds. It inhabits bushes, and rises every now and then upon its hind legs for the sake of surveying its vicinity. It then stoops down and darts under cover, from which custom it has no doubt obtained the name of duicker, or the stooper. The guevei (A. pygmaa) consists of two well-rnarked varieties, if two distinct species have not been confounded under a single name. At present we shall allude only to the smaller, which is remarkable for its diminutive size. A female in Bullock's Museum scarcely exceeded the general dimensions of a Norway rat, and the legs were no thicker than a goose's quill. 'The gueveis are brought from the coast of Guinea, and are sometimes observed to occur in the vicinity of the Cape of Good Hope.

One of the largest of the African antelopes is the bubale (A. bubalis of Pallas), equal in size to a stag. It congregates in troops, among which frequent and sometimes fatal combats take place. This species was well known to the ancients, and is represented among the hieroglyphical figures of the temples of Upper Egypt. It inhabits Barbary and the Great Desert of Northern Africa.

We may here mention the gnu, as an animal classed by Sparrman and others among the antelopes. It assembles in large herds among the southern, and probably the central deserts of Africa. It is not now found nearer the Cape than the great Karroo district. Of this animal there appears to be more species than one. 
The next group which demands our notice is the bovine tribe, including all the larger kinds of horned cattle. Of these, the only species peculiar to Africa is the Bos caffer, or Cape buffalo, the qu'araho of the Hottentots, a fierce and vindictive animal of great strength. This species is characterized by the dark rufous colour of its horns, which spread horizontally over the summit of the head, with their beams bent down laterally, and the points turned up. They are from eight to ten inches broad at the base, and divided only by a slight groove, extremely ponderous, cellular near the root, and five feet long, measured from tip to tip along the curves. The hide is black and almost naked, especially in old animals. This buffalo lives in herds, or small families, in the brushwood and open forests of Caffraria. According to Sparrman, he is not content with simply killing the person whom he attacks, but he stands over him for some time in order to trample him with his hoofs and heels, at the same time crushing him with his knees, and tearing to pieces and mangling his whole body, and finally stripping off the skin with his tongue. The surest way to escape is, if possible, to ride up a hill, as the great bulk of the buffalo's body, like that of the elephant, is a weight sufficient to prevent his vying with the slender and fine-limbed horse in swiftness. It is said, however, that in going down hill, this formidable animal gets on much faster than the horse.

The goat and sheep tribe, so valuable, especially the latter, to the human race, present respectively a species peculiar to the continent of Africa. The Egyptian goat, by some however regarded as nothing more than a variety of the domestic breed, is distinguished by the great convexity of its facial line, and a depression between the face and the forehead. The lower jaw projects beyond the upper; the ears are long and flat, and the horns are either very small, and arched slightly backwards, or are entirely wanting. The female scarcely differs from the male in external appearance, with the exception of the straighter outline of the face. It inhabits Upper Egypt. The other animal above alluded to is called the bearded sheep (Ovis tragelaphus). It inhabits the desert steeps of Barbary and the mountainous portions of Egypt. 
We have now enumerated, with occasional brief descriptions and interspersed notices of their history and habits, the greater proportion of the more remarkable quadrupeds of Africa. To extend the list would have been both easy and agreeable; but we trust that the preceding sketch will suffice to exhibit the prevailing and peculiar features of this branch of African zoology, even though our confined limits should have axcluded many minor details, not in themselves devoid of interest, though unessential to our present undertaking. The great preponderance of the antelope tribe, the existence of the giraffe and the hippopotamus, and the numerous troops of equine animals, such as the zebra and the quagga, may be stated as forming the principal zoological characters of this extensive continent.

\section{CHAPTER XIX.}

\section{Natural History of the Birds of Africa.}

WE shall next take a rapid survey of some other departments of the natural history of Africa; and continuing, as we have commenced, with a certain degree of systematic arrangement, the second great class which attracts the attention of the traveller is that of birds.

The arid and wide-spread plains which compose so large a portion of this continent, are unfavourable to the existence and multiplication of the feathered race. Yet the more umbrageous banks of rivers, the extensive forests which here and there prevail to check the drifting of the desertsand, and those green and grateful oases which towards evening cast their far shadows across a waterless land, harbour in their cool recesses many a gorgeous form of feathered life. Nor can we suppose that the mountain-summits, and those Sicrras which occasionally interrupt the horizontal view of the bleached wilderness, are uninhabited by birds of prey, eagle-eyed and swift of wing, there perched securely amid their rocky fortresses, but ever ready to descend with eager cry, when the blast of the simoom overwhelms the 
exhausted caravan, or the weary camel "ship of the desert" is seen to stoop its mast-like neck, and the glassy hue of death suffuses its gentle eye, not from the turbulence, but the want of waves. And if, as has been supposed, some of the great African rivers empty their translucent streams into an interior and sea-like lake, many an unknown but beautiful aquatic bird must haunt its mysterious and long-sought-for shores, and revel in the crystal depths of those delusive waters which have already led on to death so many of our brave and devoted countrymen. To these, however, so long as heroic enterprise is valued, they will likewise prove the waters of immortality, though, to their surviving and deploring friends, bitter as the fountain of Marah.*

If the multiplicity of species, even in the class of quadrupeds, be found an insuperable obstacle to a detailed account in such a publication as the present, far more must we curtail our remarks when treating of the feathered race, the number of which, not unfamiliar to the ornithologist, does probably not fall far short of 6000 species. Let us commence with the carnivorous tribes.

Several species of vulture occur in Africa, where, as in other countries, they follow troops of armed men,

"Sagacious of their quarry from afar,"

in the hope of ere long preying on their slaughtered bodies. It is, however, by the sense of sight, and not by that of smell, that these birds so quickly discover and assemble round their victims on the battle-field.

The eared vulture (l'oricou of Le Vaillant) is a gregarious species which inhabits the southern parts of Africa. Their nests are placed very near each other, and the birds are seen sitting in vast numbers about the caverns of the rocky mountains where they breed.

A doubtful species called the armed vulture, is mentioned

* The writer of these notices dwelt at one time, during his boyhood, for many months in the family, and constant companionship of the late lamented Major Laing, and was in habits either of personal intimacy or correspondence with the unfortunate Bowdich, Oudney, Clapperton, and the younger Park, who so lately perished following his father's footsteps. 
by Browne in his African Travels, and is said to be extremely frequent in the country of Darfur, where it flies about in thousands.

The African snake-eater (Falco serpentarius, Linn.) is usually placed between the rultures and hawks. It is a longlegged species, of peculiar aspect, resembling in some respects rather a wader than a bird of prey. It inhabits dry open plains in the lower parts of Southern Africa, and feeds on reptiles. Le Vaillant found in the craw of a single bird twenty-one young tortoises, three snakes, and eleven lizards, and, besides these, there was a large ball in the stomach formed entirely of the scales of tortoises, the vertebræ of snakes and lizards, the legs of locusts, and the wing-cases of coleopterous insects.

Of more noble habits are the eagles, hawks, and other birds of. prey, which, for the most part, disdaining the corrupting carcasses, whether of man or beast, overcome by speed of wing, and pounce with their talons on all such living creatures as they are able to subdue.

Among the eagles of Africa may be mentioned the griffard eagle (Falco armiger), native to the country of the $\mathrm{Na}$ maquas, and the imperial eagle ( $F$. imperialis of Temm.) described by Savigny in the splendid French work on Egypt. This latter species also inhabits the mountains of the southern parts of Europe.

Of the numerous hawks, or smaller species of the falcon tribe which inhabit this continent, we shall mention in the first place, the chanting falcon ( $F$. musicus, Daudin). We must not suppose, from the name of this species, that its notes in any way resemble the harmonious tones of the nightingale, or those of even our less celebrated songsters. Its voice is merely a little clearer than usual, although it seems impressed with a high idea of its own powers. It will sit for half a day perched upon the summit of a tall tree, uttering incessant cries, which the darkness of the night is sometimes insufficient to terminate. It builds in woods in the interior of Caffraria, and commits great havoc among quails and partridges. The crested African falcon ( $F$. galericulatus) resembles the peregrine falcon of Europe. It dwells by the seashore and the borders of lakes, and feeds on fish, crabs, and the testaceous tribes. The ranivorus, or frog-eating falcon ( $F$. ranivorus) is a native of the Cape of 
Good Hope. It appears to be allied to the moor-buzzards in its manners. It builds its nest among rushes, with the stalks of the leaves of water-plants, and feeds chiefly on frogs and young waterfowl.

The next family of carnivorous birds are the nocturnal tribes called owls, which may be said to bear the same relation to the more active and elegant hawks that moths do to butterflies. Africa is by no means rich in owls, at least very few have attracted the notice of travellers in that country. We shall here mention only the very beautiful falconian owl of Latham (Strix Africana), which appears during the short-lived twilight, and moves with rapid flight.

We may place, as intermediate between the regular birds of prey and the passerine species, those called butcher-birds, of which Africa produces a great variety of kinds. The habits of the collared shrike (Lanius collaris) are described by Le Vaillant. When it sees a locust, a mantis, or a small bird, it springs upon it and immediately carries it off, in order to impale it on a thorn, which it does with great dexterity, always passing the thorn through the head of its victim. Every animal which it seizes is subjected to the same fate; and it thus continues all day long its murderous career, apparently instigated rather by the love of mischief than the desire of food. Its throne of tyranny is usually a dry and elevated branch of a tree, from which it pounces on all intruders, diriving off the stronger and more troublesome, and impaling the inexperienced alive. When hungry, it visits its shambles, and helps itself to a savoury meal. The Hottentots assured Le Vaillant that it does not love fresh food, and therefore leaves its prey on the gibbet till it becomes putrescent. But beneath the scorching sun of Africa this process of decomposition sometimes does not take place, from the rapid exhalation of the animal fluids in a warm and arid atmosphere ; and, consequently, whatever spiny shrub may have been chosen by the butcherbird as the place of execution, is frequently found corered not with sweet-smelling and many-coloured blossoms, but with the dried carcasses of singing-birds, and the bodies of locusts and other insects of the larger size. This unamiable and irascible bird is figured and described in the fourth 
part (plate 52) of the valuable "Illustrations of Ornithology," so well conducted by Sir William Jardine, Bart., and Mr. Selby. Several species of shrike likewise occur in the island of Madagascar.

With species pertaining to the beautiful and melodious family of the thrushes, Africa is by no means abundantly supplied. The Cape thrush (genus Brachypus, Swainson) is found, as its name imports, in Southern Africa, and another species (T. Phanicopterus, Temm.) occurs in Senegal. Its plumage is of a fine bronzed black, glossed with blue and violet; the wings and tail are dull black, with all the feathers edged with metallic green ; the wing-coverts are bright red ; the beak and legs are black. If, however, we were to regard the genus as formerly constituted, we should here name some of the most splendid of the feathered race ; for example, the shining thrush, and that other species called the blue and green daw by Edwards, both of which probably belong to the genus Lamprotornis, the greater proportion of which seems peculiar to Africa. The rose-coloured ouzel, one of the rarest and most beautiful of British birds, is also found in Africa, where its love of locusts is more amply gratified than we hope it will ever be in this cold and cloudy clime.

Passing over the extensive family of the sylviada, which includes the finest song-birds of temperate countries, we shall here present the remark that the feathered tribes of tropical and other sultry regions are in general more distinguished for their gorgeous plumage than the harmony or varied intonation of their voices. It is chiefly among the obscure and monotonously-plumed species that we find the most accomplished warblers, such as the sombre nightingale, which in the leafy arbours of France and England makes such rich amends for his unadorned and quaker-like attire :

" The wakeful bird

Sings darkling, and, in shadiest covert hid, Tunes her* nocturnal notes."

Among the Fringillida we may notice the buntings, of which the Whidah-bird, or long-tailed bunting (genus Vidua,

* We are not aware that the female nightingale sings,--but the words of Milton are sacred. 
Cuvier), is remarkable for the changes which the male bird assumes at certain seasons of the year, and which, from the dropping away of the lengthened feathers of the tail, and the alteration in the colours of various parts of the plumage, produce a total difference in the appearance of that sex. Angola is its native country. There is a nearly-allied species from the Cape of Good Hope.

The Greeks applied the name Kodowos to a small species of crow, probably the jackdaw. The same term has been used in later times to designate a genus of birds found in Africa, though not peculiar to that continent,- the genus Colius. These birds, though the structure of their feet offers no analogous formation, climb trees like parakeets, dwell in large troops, build together numerous nests on the same bushes, and are sometimes found sleeping together in masses, suspended by the feet, with their heads downwards They live on fruits, and occur both at the Cape of Good Hope and in Senegal.

Of the genus Buphaga, peculiar to Africa, there are only two species, called the African and the red-billed beefeaters. The former is a singular bird, both in its aspect and manners. It is frequent in Senegal, and its food consists of the larvæ of œstri or gadflies, which it picks from beneath the skin of the larger cattle. Le Vaillant also observed it in the country of the Namaquas, and he states that it is usually seen in flocks of six or eight together.

Several species of roller inhabit the African continent. The European roller, commonly so called (Coracias garrula), is in fact an African species, although it sometimes beautifies the woods of more northern countries with its azure hues. Other species are found in the Angolese and Abyssinian territories.

Of the goat-sucker tribe, generically distributed over almost every country of the world, Africa also possesses a few species, of which one of great beauty was lately discovered by Rüppell, the Frankfort traveller, in Nubia and Sennaar. It is the Caprimulgus eximius of M. Temminck.

The last-named genus conducts naturally to the swallow tribe, of which Africa, if not the native country, is at least supposed to share with us the society for one-half the year. Besides its migratory species, it possesses several of a less restless character, which dwell there throughout the entire 
season, and remain for ever in ignorance of those cool and refreshing waters into which our own delightful visitants are so often seen to dip their slender wings.

The hoopoes resemble the swallows in their migratory movements, but they are classed with the Tenuirostres, on account of their slender bills. The conmon hoopoe, though an African bird, has been several times shot in Britain; and the marcheur largup of Le Vaillant appears to belong to the same genus, and inhabits the country of the Caffres.

Nearly united to the last-named species are the promerops, a limited but magnificent group, different species of which are found in Africa, India, and New-Guinea. The most remarkable of the African kinds is the red-billed promerops ( $P$. erythrorhynchus), probably first described by Dr. Iatham, from a specimen in the collection of the Dutchess of Portland. Its length, including the tail, is 15 inches. The general colour is black, glossed with red, violet, and golden-green; the red predominates on the head, the golden-green on the wing-coverts, and the violet on the back and tail. All the tail-feathers, except the two in the centre, are marked near the tip by an oval white spot on each side the web ; and several of the quill feathers of the wings have also a white spot on their inner webs, near the tip. The bill is long, slender, moderately curved, and of a red or orange colour. The legs are also red.

Although Africa cannot boast of possessing any of those jewels of urnithology, the fairy humming-birds, which dart like sunbeams among the flowery parterres of the western world,-

\section{"And on their restless fronts}

Bear stars, illumination of all gems ;"

yet the eye of the naturalist who has studied the unsurpassed splendour of the soui-mangas, or sugar-eaters, will scarcely desiderate any other beauty. These birds, belonging to the genus Cynniris of Baron Cuvier, were formerly classed with the creepers. They are distinguished by their long and slender bills, the mandibles of which are finely toothed or serrated on their edges ; and their tongues, which are capable of considerable extension, are terminated by a small fork. Several of the species occur in the Indian archipelago, but the greater proportion are of African $\mathrm{E}$ e 2 
origin, and may be said to form the most signal and admired feature in the ornithology of that country.

The superb creeper is an elegant bird, described and figured in the magnificent work of $\mathrm{M}$. Vieillot. Its length is six inches: the crown of the head, upper part of the neck, smaller wing-coverts, back, and rump, are bright greenish-gold; the throat is violet-blue, glossed with gold; across the upper part of the breast runs a bar of bright gilded-yellow, beneath which the whole upper parts are deep-brownish crimson; the wings and tail are blackishbrown; the legs are also brown, and the bill is black. This species was discovered in Malimba, by M. Perrien, and is one of the rarest as well as most beautiful of the genus.

Another highly-adorned species, such as

"Limners love to paint, and ladies to look upon,"

is called, par excellence, the African creeper. It is a native of the Cape of Good Hope, and is found in woody situations. In addition to a splendid plumage, it is highly admired for its musical powers, and its song is by some esteemed equal to that of the nightingale.

The spotted-breasted creeper (C. maculata) dwells in the forests of Malimba, and frequently approaches the habitations of the natives, allured by the flowers of the cytisus cajan, commonly called the Congo pea, which, according to Dr. Shaw is much cultivated by the negroes. The violetheaded creeper (C. violacea) is a native of the Cape of Good Hope. It likewise dwells in woods, and is said to build a nest of singularly elegant and ingenious structure. Our restricted limits will not admit of our expatiating on this delightful tribe.

The next African genus which claims-our attention is Merops, which includes the bee-eaters, a group not more remarkable for beauty of colour than gracefulness of form. These birds feed on insects, and build their nests in the holes of banks. The common bee-eater (Merops apiaster), notwithstanding its designation, is one of the rarest of European birds, and is certainly one of the most beautiful. It occurs in Africa, and spreads from thence into Greece and the Mediterranean Archipelago. Many other species of 
bee-eater inhabit this continent; but for these we must refer the reader to Le Vaillant and other writers.

Amid the intinitely varied forms and colours which characterize and adorn the feathered race, we know of none more worthy of admiration than those exhibited by the great family of the kingfishers. The size and length of the bill are indeed somewhat disproportioned to the dimensions of the body; but the shining silky lustre of the plumage, and the finely varied hues of the most brilliant green and blue, contrasted with different shades of orange, black, and brown, render this genus one of the most showy and attractive within the range of the ornithological system. The continent which forms the subject of our present disquisition is rich in the genus. We shall at present, however, mention only the Smyrna kingfisher ( $A$. Smyrnensis), which, when in perfect plumage, is one of the most brilliant of the feathered race.- "The lucid blue of the wings," says Dr. Shaw, "scarcely yielding in lustre to those of the splendid butterfly called Papilio Menelaus." Its colours seem to vary in different individuals. Several fine species of this extensive genus occur in the island of Madagascar.

Among the more remarkable of the African birds we must not omit to mention the species of the genus Buceros, commonly called hornbills. These occur also in Celebes and the Philippine Islands, but many species are peculiar to Africa. The hornbills may be said to occupy the same station in the old world as the toucans do in the new. Both are alike distinguished by the enormous size of their bills, and by a mixture in their dispositions of the carnivorous with the frugivorous propensities. The African hornbill ( $B$. Africanus) is entirely black, and nearly as large as a turkey. The only other species of this singular genus which we shall mention, is the crowned hornbill ( $B$. coronatus). Compared with the preceding it is a very small bird, scarcely equalling the dimensions of a magpie. Le Vaillant saw a flock of more than five hundred of these birds assembled in company with crows and vultures, and preying on the remains of slaughtered elephants. The crowned hornbill is figured by Mr. Swainson in the third volume of his beautiful illustrations.

We shall now take a brief view of the scansorial or 
climbing birds of Africa. Several woodpeckers inhabit this continent. The double-bearded woodpecker (Picus drophrys) inhabits Southern Africa; and the crested woodpecker (P. minutus, Temm.) is found in Senegal. The gold-shafted woodpecker (now placed in the genus Colaptes) is likewise an African species.

Many kinds of cuckoo occur in Africa. The old Linnæan genus Cuculus has been greatly subdivided by modern writers. The group included under the genus Centropus are remarkable for the long claw with which the inner hind toe is furnished. They are found in India, Africa, and the island of Java. The didric or shining cuckoo (Cuculus auratus) is probably the most beantiful of the tribe. The upper parts of the plumage are of a rich golden-green; on the head are five stripes of white, two above the eyes, like eyebrows, passing behind ; two more, shorter and narrower, beneath the eyes; and one on the middle of the forehead. The wing and tail coverts, and the secondary quills are tipped with white. Most of the under-parts are likewise white. This bird was found by Le Vaillant, inwards from the Cape, near Kok's Kraal. He named it didric, from its continually uttering these syllables in various modulations, when perched on the extremities of large trees.

While recording the names of so many species remarkable for their lustrous plumage, we must not here omit to mention others not less notable for their singular instincts and modes of life. Among these the indicators or honeyguides, by some authors classed with the cuckoos, are deserving of special notice. One species described by Dr. Sparrman is said to attract the notice of the Dutch and Hottentots by a shrill cry of cher, cher; and when it perceives itself observed, it flutters onwards to the hive of a wild bee, in hopes of partaking of the plundered honey. "I have had frequent opportunities of seeing this bird, and have been witness to the destruction of several republics of bees, by means of its treachery. I had, however, but two opportunities of shooting it, which I did to the great indignation of my Hottentots."

We may here observe, that naturalists themselves seem occasionally to belong to that irritabile genus, of which poets are said to form the principal cumponent parts. Though Sparrman asserts that he was a frequent eyewit- 
ness of the curious instinctive habits of the honey-guide, yet Le Vaillant doubts if that traveller ever saw the bird at all. He says that the account is merely a repetition of a fable that is known and believed by credulous people at the Cape, and that it is false to suppose that the bird seeks to draw man after it for the purpose of sharing the plundered sweets ; the fact being that the bird calls not the man, but that the man knows by attending to the natural cry of the bird in search of food, that he will be sure ere long to find the stores of the bee. According to Bruce, the moroc, for so this singular species is sometimes named, occurs in Abyssinia; but he also throws discredit on Sparrman's relation. We have seen, in the preceding chapter, that Lichtenstein doubted the truth of Le Vaillant's account of the camelopard; we now find Le Vaillant himself equally skeptical of the accuracy of the Swedish traveller, and joined therein by Bruce, whose own statements were at one period scarcely credited at all. However, to conclude a subject which has already too long detained us, we shall observe that Mr. Barrow, a most careful and accurate inquirer, though not a professed zoologist, confirms Dr. Sparrman's account, as follows:- "Every one in that country (the interior of the southern extremity of Africa) is too well acquainted with the moroc to have any doubts as to the certainty either respecting the bird or its information of the repositories of the bees."

The sagacious and imitative family of the parrots (Psittacida) is the next to demand a brief record. Though one of the most numerous groups of the feathered creation, it is by no means abundant in species, when considered merely in reference to its African relations. The gorgeous maccaws are peculiar to South America, the cockatoos to New-Holland and the Eastern Islands, the lories to the East Indies and the Moluccas ; and the greater proportion of parrots and parakeets, commonly so called, are more truly characteristic of the tropical regions of other countries than of Africa. Yet here also this noisy and loquacious race are not unknown, although the far-spread forests are its chosen dwelling-places rather than the barren sands. Africa, however, has also her shady bowers as well as thirsty Saharas ;

"For $\mathrm{He}$, at whose command the parched rock Was smitten, and poured forth a quenching stream, 


\section{Hath softened that obduracy, and made \\ Unlooked-for gladness in the desert place \\ T'o save the perishing."}

The Greeks and Romans became acquainted with the parrot kind, in consequence of certain species of these birds having been imported from the East soon after Alexander's Indian expedition. The Alexandrian parrot, especially, so remarkable for its elegant form and docile disposition, is generally supposed to have been brought to Europe about that time from the island of Ceylon, the ancient Tabrcbane. In the reign of Nero, the Romans introduced other species from different quarters of $A$ frica. They were highly prized by that luxurious people, who lodged them in superb cages of silver, ivory, and tortoise-shell ; and the price of a patrot in those days frequently exceeded that of a slave. Nor did Ovid think it beneath him to write a lengthened elegy on the death of Corinna's parrnt, - a bird, which, in the love it bore its mistress, seems to have emulated that of the dying Greek for his country :-

\section{"Clamavit moriens lingua, Corinna, vale!}

It is only in these degenerate days that the keeping of a cockatoo is brought forward in a court of justice in proof of an alienated or imbecile mind.* We trust, that in some instances, at least, such inference may be fairly classed as a " non sequitur."

One of the earliest imported of the African species appears to have been the gray or ash-coloured parrot ( $P$ sittacus erithacus), still renarkable for its easy loquacity and general imitative powers. To this species probably belonged the individual mentioned by Cælius Rhodoginus, and which belonged to Cardinal Ascanius. "I cannot," says that author, "omit an extraordinary wonder seen in our times. This was a parrot at Rome, belonging to Cardinal Ascanius, who purchased it for a hundred gold pieces, and which, in the most articulate and uninterrupted manner, recited the Apostles' Creed as well as the best reader could have done, and which, as a most extraordinary and wonderful thing, I could not pass unnoticed."

* See the case of Dundonald versas Roy, as lately reported at length in the Scoteh newspapers. 
We shall mention only two other African species of this tribe, viz. the damask parrot ( $P$. infuscatus), of which an interesting account is given by Le Vaillant, and the Guinea parrot ( $P$. pullarius), apparently figured on the 40th plate of the second volume of Seba's "Thesaurus.

That division of the Linnæan genus Bucco now called Pogonias, is peculiar to Africa. It contains about six species, of which the manners are little known. That called the Abyssinian barbican by Latham, was observed to cling to the branches of trees like a woodpecker.

Of the Trogons, an extensive tribe, of brilliant plumage but ungraceful forms, the greater part are proper to A sia and America. We are indebted to Le Vaillant for the figure and description of an African species discovered by him in the country of the Caffres, and called Narina, which, it seems, in the Hottentot language signifies a flower. It is the Trogon narina of systematic writers.

We come now to a limited tribe, entirely peculiar to Africa,- the plantain-eaters, genus Musophaga. These are large birds, elegantly shaped, and richly coloured. The species are few in number, and their history is still obscure. Allied to the preceding are the Touracos, likewise characteristic of the African continent. One of the most beautiful was classed by Linnæus with the cuckoos, - the Cuculus persa of that great observer. Le Vaillant says that there are great numbers of tourncos in the country of the Kottinquas, - that they are very difficult to shoot, as they perch only on the summits of the tallest trees, and rarely suffer any one to come within gunshot,-but that they are easily caught alive by snares, baited with such fruits as are in season. He adds that they are excellent eating. Another species of this genus which it is delightful to look upon, is the Pauline touraco, Corythaix Paulina. It inhabits Southern Africa. M. Vieillot had one alive, and he informs us that its manners were mild and familiar: it lived on succulent fruits, and was fond of sugar; its habits were active, and its voice sonorous and apparently ventriloqual.

The different tribes and genera belonging to the great order of gallinaceous birds are the next to claim our regard. The sympathies of such of our readers (if such there be) as are regardless of that beauty of form and splendour of 
colour to which we have already so often attracted their attention, would probably yield more readily to certain culinary associations connected with poultry, turkeys, pheasants, grouse, \&c.; all of which, and many more equally dear to the late Dr. Kitchener, belong to the present extensive division of our subject. It happens, however, that cocks and hens are of eastern origin, that turkeys are native only to America,-that pheasants come from the banks of the Phasis, - and that grouse are peculiar to northern countries. We must therefore, in the mean time, be contented with a few pigeons.

The genus Columba is widely diffused over both the temperate and tropical regions of the eartl. Its species abound in Europe, Asia, Africa, and America; and, even in the ferests of the far-distant islands of the Southern Ocean, their radiant plumage

"Fills many a damp obscure recess
With lustre of a saintly show."

One of the most magnificent of the tribe is the hackled pigeon (C. Francice). It is distinguished from all others by the irregular form of the feathers on the head, neck, and breast, which are long and narrow, and terminate in a shining appendage resembling in consistence, though not in colour, that with which the wing-feathers of the Bohemian chatterer are furnished. The species inhabits Southern Africa and the island of Madagascar. A still more singular bird is the parabolic pigeon ( $C$. arquatrix). It was discovered by Le Vaillant, and is figured in his splendid work on the birds of Africa. The flight of this species is very remarkable. It never proceeds in a straight line, but on commencing its route it describes a parabola, and continues forming a series of ares during the whole time, frequently uttering a peculiar cry. It inhabits the forests of Anteniquois, and is a great enemy to the white eagle.

The Guinea fowls, or pintados, are entirely peculiar to Africa as native species, though they now breed freely as domestic birds both in Europe and America. There are three kinds of this bird known to naturalists, viz. the Guinea pintado (Numida meleagris), common in our poultry-yards; the mitred pintado ( $N$, mitrata); and the crested pintado (N. cristata). 
Quails are remarkable for a certain compactness of form and neatness of plumage, which, in the absence of brilliant colouring, produces a highly pleasing effect. In regard to the African species, we shall content ourselves with naming the Madagascar quail (Coturnix perlata), which is about twice the size of our British visitant. It is also distinguished from the others by the strength of its beak.

Very few partridges, properly so called, occur in this sandy continent. The Barbary partridge (Perdrix petrosa) is abundant along the African shores of the Mediterranean. It also occurs in Teneriffe, and along the western coast as far as Senegal. Of the genera Pterocles, Francolinus, and Turnix, there are likewise representatives in this country. Cranch's Francolin ( $F$. Cranchii) was discovered by the indefatigable and unfortunate collector whose name it bears, during the ill-fated expedition to explore the source of the Congo under Captain Tuckey. It is described by Dr. Leach in the appendix to the published narrative of that disastrous voyage.

Of the African grouse, we may say, as Horrebow says, in his brief chapter "On the Rats of Iceland,"-_"There are no rats in Iceland;" so neither are there any grouse in Africa.

A few lines may now be devoted to a species which not only forms the most remarkable character in the ornithology of Africa, to which country it is now believed to be entirely peculiar, but presents in itself the most singular example of the feathered race. This extraordinary bird is the ostrich, the tallest of its class, and probably the swiftest of all running creatures. It is distinguished from every other bird by having only two toes on each foot. It inhabits the open and sandy plains of a great extent of Africa, from Barbary to the Cape of Good Hope; and being consequently native to one of the most ancientlypeopled countries of the earth, it has excited the attention of mankind from the remotest periods of antiquity. It is frequently mentioned in the Book of Job, and in other portions of the Old Testament. Herodotus, among the early Greek writers, was acquainted with its history and appearance; and in after-times it was not only frequently exhibited by the Romans in their games, but the brains of F f 
hundreds at a time were scooped out, and served up as a choice delicacy on the luxurious table of Heliogabalus.

To exemplify the great strength and swiftness of this gigantic biped, we shall transcribe the following circumstance, narrated by Adanson, as having taken place at Podor, a French factory on the southern bank of the river Niger:- "Two ostriches which had been about two years in the factory, and, although young, were nearly of their full size, were so tame that two little blacks mounted both together on the back. of the largest: no sooner did he feel their weight, than he began to run as fast as possible, and carried them several times round the village, as it was impossible to stop him otherwise than by obstructing the passage. This sight pleased me so much that I ordered it to be repeated; and, to try their strength, directed a fullgrown negro to mount the smallest, and two others the largest. This burden did not seem at all disproportioned to their strength. At first they went at a tolerably sharp trot, but when they became heated a little, they expanded their wings as though to catch the wind, and moved with such fleetness that they scarcely seemed to touch the ground. Most people have, one time or other, seen a partridge run, and consequently must know that there is no man whatever able to keep up with it; and it is easy to imagine that if this bird had a longer step, its speed would be considerably augmented. The ostrich moves like the partridge, with this advantage; and I am satisfied that those I am speaking of would have distanced the fleetest race-horses that were ever bred in England: it is true they would not hold out so long as a horse, but they would undoubtedly be able to go over the space in less time. I have frequently beheld this sight, which is capable of giving one an idea of the prodigious strength of an ostrich, and of showing what use it might be of, had we but the method of breaking and managing it as we do a horse."

Greatly inferior in size, but not very dissimilar in form, are the bustard tribe, of which the most recently discovered African species is designated Otis Denhami by Mr. Vigors, in honour of the late intrepid and accomplished traveller of that name.

We now arrive at the Grallatores, or long-legged birds, 
commonly called waders, on account of the semi-aquatic propensities by which so many of them are distinguished. Of these the most gracefully formed are the demoiselles, or lady-birds (Ardea pavonia and Ardea virgo, Linn.), both of African origin. They are not unfrequently exhibited in menageries under the name of crown-birds, or Balearic cranes.

The flamingo tribe are remarkable for the length of their legs. The species occasionally found in Europe (Phœnicopterus ruber) is native to the warmer regions of -Asia and Africa. The bird described under that name by Alexander Wilson, in his American Ornithology, is a distinct species, mentioned as such long ago by Molina, in his Natural History of Chili. It is alluded to by Thomas Campbell in his Gertrude of Wyoming :-

"Then, where of Indian hills the daylight takes His leave, how might you the flamingo see Disporting like a meteor on the lakes."

The lesser flamingo ( $P$. minor of Vieillot and Temminck) is a species discovered of late years as an inhabitant of various parts of Africa, from Senegal to the Cape of Good Hope.

The gigantic stork (Ciconia argala) though well known in Bengal, is likewise an African species. This bird is sometimes upwards of six feet in height. It is very common in many of the interior parts of Africa, and is called marabou in Senegal. According to Major Denham, it is protected by the inhabitants on account of its services as a scavenger. Its appetite is most voracious, and nothing comes amiss to its omnivorous propensities. Smeathman has given a long account of a tame bird of this species. It regularly attended the hall at dinner-time, and placed itself behind its master's chair. It frequently helped itself to what it liked best; and one day darted its enormous bill into a boiled fowl, which it swallowed in an instant. It used to fly about the whole country, and generally roosted high among some silk-cotton trees. From this station, at the distance of two or three miles, it could see when the dinner was carried across the court, when it immediately took wing, and flying with great swiftness, arrived in time to enter the house with some of those who carried the dishes. 
It sometimes remained in the room for half an hour after dinner, turning its head alternately from side to side, with an appearance of unusual gravity, as if listening to the conversation. It one day swallowed a cat. Is this the Ardea dubia of Gmelin?

Let us here insert the name of the umber (Scopus umbretta, Linn.), an African species, - the only one of it genus, of the manners of which we are still entirely ignorant.

Of the snipe and woodcock kind several species irhabit Africa. Of these we shall mention no more than the Cape snipe (Rhynchia Africana of Lesson), which occurs specifically the same, or at least apparently identical, in Bengal.

Of the sandpiper tribe (Pelidna, Cuvier) a few occur along the African shores, and a new species of phalarope ( $P h$. Fimbriatus) has been recently described by M. Temminck as native to Senegal.

The genus Cursorius is found in all the quarters of the globe, with the exception of America. The double-collared courier (C. Bicinctus) inhabits the interior of Southem Africa; Temminck's courier (C. Temminckii, Swainson) is found at Sierra Leone; and the violet-winged courier ( $C$. chalcopterus, Temm.) comes from Senegal.

The plover family are numerous in almost all parts of the world. Africa possesses nearly a dozen species, of which we shall mention merely the crowned plover (Charadrius coronatus), one of the largest of the genus, which occurs at the Cape of Good Hope.

Of the Palmipedes, or web-footed water-fowl, we know of no great number peculiar to Africa. These birds are of wandering habits, and being possessed, in addition to their great power of wing, of the faculty of resting on the water, we can place no limits to the extent of their migratory movements. They thus become more-cosmopolite than many of the other tribes, and are therefore less entitled to our attention during an exposition of the peculiar and more characteristic features of a particular continent.

The first of this order which we shall name is the Cape penguin (Spheniscus Capensis). This rird is found on several of the southern portions of our globe, especially at the Cape and the Malouin Islands. It lives in immense 
numbers, congregated together in spots called rookeries by our voyagers. The eggs are much esteemed.

The pelican ( $P$. Onocrotalus, Linn.), common alike to Asia and the eastern countries of Europe, is also found in Africa, where it has been observed both in Egypt and the Cape of Good Hope.

Of the singular genus called plotus or darter, Le Vaillant made us acquainted with a species from Senegal and the Cape. It was also found in the interior of the country by Major Denham.

The elegant and long-winged terns or sea-swallows may be enumerated among the African tribes. The slenderbilled tern (Sterna ienuirostris, Temm.) is found upon the western coasts, and the white tern (S. candida, Gmelin) inhabits the Cape of Good Hope.

The buoyant and pearly-plumaged gulls, though more characteristic of the northern regions, are occasionally seen along the African shores. We are not, however, acquainted with any species peculiar to this continent.

The genus albatross (Diomedea) probably contains the largest and longest winged of all the aquatic species. The wandering albatross (D.exulans) is equal in size to a swan, and its wings extend about ten feet. This bird is principally met with in the seas adjacent to the Cape of Good Hope.

The Cape petrel (Procellaria Capensis), as its title implies, occurs also near the last-named locality. It is common in the southern seas, but more especially in the vicinity of the Cape, where it flies in immense flocks. It is extremely voracious, and feeds on fish and the dead carcasses of whales. When caught, it squirts a quantity of oil from its nostrils.

The spur-winged goose (Plectropterus Gambensis) is a singular species inhabiting Gambia and other parts of Africa. The anterior angles of its wings are armed with sharp projecting spines.

The mountain goose (Anser montana) is a large species, with the wing feathers, and those of the head, of a bright shining reddish green. According to Latham, it inhabits the Cape of Good Hope, where it keeps mostly on the hills, and feeds on grass and herbs.

Among the larger of the web-footed tribes we must not omit to mention the Egyptian goose (Chenalopex Egyptiaca, 
Stephens), so remarkable for its strong attachmert to its young. It was worshipped by the ancient Egyptians, and its sculptured figure is still recognisable among the hieroglyphical representations of the Theban temples. It also occurs in the southern regions of Africa, and has not unfrequently been imported into Britain to beautify the waters of our pleasure-grounds; but the love of liberty is deeply implanted in this bird, and it is with difficulty that even the young, born and bred in northern climates, are retained for a continuance in a state of satisfied domestication.

The crimson-billed sheldrake (Tadorna erythrorhyncha) inhabits the Cape of Good Hope; and a species of muskduck (Anas Nilotica of Gmelin) is found in Upper Egypt. It is easily tamed, and lives on good terms with other poultry.

From the preceding summary, the student of ornithology will be able to form a sufficiently correct idea of the prevailing features which characterize this branch of science in Africa; and, by comparing the present sketch with those which we purpose to exhibit of other countries in the future volumes of our series, he will likewise be enabled to estimate the peculiarities by which the continent in question is distinguished from all the other quarters of the globe.

\section{CHAPTER XX.}

Natural History of the Reptiles, Fishes, Shells, Insects, \&c. of Africa.

INTERMEDIATE between the birds and fishes are the reptile race, divided by naturalists into four principal branches, the Chelonian, the Saurian, the Ophidian, and the Batrachian reptiles. Of all these, Africa, " fruitful in monsters," produces some remarkable examples.

In regard to the geographical distribution of reptiles, the first and most general observation is, that they augment in number as we advance towards the equatorial regions. While Sweden possesses scarcely a dozen lizards and 
snakes, about three or four frogs and toads, and not a single tortoise, the temperate parts of Europe produce about forty snakes and lizards, and several of the tortoise tribe. As soon as we gain the southern extremity of Spain, the number of species in these tribes greatly increases, and in Andalusia the African complexion of the country is still further manifested by the appearance of the chameleon. On proceeding further south, not only does the number of reptiles increase, but they also augment in size, till, from the Tropic of Cancer onwards, and beyond the Line, we meet with the crocodiles, caymans, boas, and other giants of the reptile race. For the present, how $€$ ver, we must confine ourselves to a brief allusion to a very limited number of the African tribes.

1st, Chelonian reptiles or tortoises and turtles. Several of this division occur in Africa, such as the Testudo Graca, the Testudo triunguis, \&c.

$2 \mathrm{~d}$, Saurian reptiles. To this division belong the crocodiles and lizards, the geckos, chameleons, and many others.

The common crocodile (Lacerta crocodilus), celebrated in the ancient history of Egypt, is spread over a considerable extent of this continent.
"Erewhile, emerging from the brooding sand,
With tiger paw he prints the brineless strand;
High on the flood, with speckled bosom swims,
Helmed with broad tail, and oared with giant limbs ;
Rolls his fierce eyeballs, clasps his iron claws,
And champs with gnashing teeth his massy jaws.
Old Nilus sighs through all his cane-crowned shores,
And swarthy Memphis trembles and adores."

There are several different kinds of crocodile in the old and new world, and their tempers and dispositions seem to vary in different localities. Humboldt and Mungo Park regarded them with fear and trembling, while Audubon and $\mathrm{Mr}$. Waterton hold them in little consideration either as friends or foes. Though seldom tamed, they are not by any means incapable of domestication, as has been demonstrated by many examples, both in ancient and modern times.

Many lizards occur in Africa. We shall only mention one found near Mourzouk. It is called aselis, and, if not a true lizard, resembles one in form. When alarmed, it 
buries itself in the sand; and when dropped from a height, it immediately sinks beneath the surface of the spot on which it fell. "These little creatures," says Captain Lyon, "are eagerly bought by the girls and married women, for the purpose of ascertaining how many children they shall have. By stretching them the skin will inmediately crack, and the women most religiously believe that for every sound they shall bear a child."

One of the most remarkable families of the saurian tribe is that which contains the chameleons. The common species (Lacerta Africana) is found in Egypt, Barbary, and the south of Spain. The changes of colour in these animals, though by some deemed fabulous, are now beyond dispute. The causes of these changes, however, and their mode of action, may still be classed among the more obscure points of natural history. They seem independent of external objects, and vary within a certain range, almost every hour.

"Non mihi tot cultus numero comprendere fas est Adjicit ornatus proxima quæque dies."

3d, Ophidian reptiles, or serpents. Among the most remarkable of the African species of this division, is the cerastes, or horned viper. It is characterized by a small curved horn over each eyelid. It lives in the sand, and was well known to the ancients. Another singular serpent is the haje (Coluber haje, Linnæus). The Egyptian jugglers, by pressing the neck of this creature between their fingers, produce a kind of catalepsy which renders it stiff and motionless. This is rather a curious fact when eonsidered in connexion with the scriptural narrative in the seventh chapter of Exodus, where the rods of the magicians when thrown down are converted into serpents.

This species was regarded by the ancient Egyptians as the emblem of the protecting divinity of the world, and its figure is frequently sculptured on each side of a globe, on the outer gates of their temples.

4th, The Batrachian reptiles, such as frogs, \&c. Africa produces comparatively few species of this division. The soil is probably too dry. We shall here mention only the short-headed toad (Rana breviceps) described by Lin- 
næus in the Amønitates Academica, vol. i. It is a very small species, native to Senegal and some other parts of Africa.

The great and almost inexhaustible class of fishes next demands our attention.

Our acquaintance with the laws which regulate the geographical distribution of this class is extremely meager : in other words, the facts illustrating the greater or less extension of their localities are few, and have never been properly generalized. From the immeasurable extent and continuous nature of the fluid which they inhabit, they are supplied by nature with greater facilities of dispersion than most other animals; while the greater equality of the temperature of water, when compared with that of either earth or air, admits, in several instances, of the same species inhabiting almost every latitude from pole to pole. Those races especially, which, travelling together in vast shoals, speedily consume the natural food which each particular spot affords, are obliged, like the pastoral tribes of old, or the woodland hunters of America, to remove from place to place in search of additional supplies, and thus the species acquires a more widely extended geographical distribution. It is thus that the cod and herring are spread over the whole extent of the Northern Ocean, and in undiminished numbers, notwithstanding the war of extermination which man and other voracious animals appear to wage against them. Those species which lead a solitary and, as it may be called, a stationary life are frequently confined within very narrow limits. The Chatodons, for example, which delight in rocky coasts covered with madrepores, attach themselves to the torrid zone, which produces so abundantly those magnificent ornaments of the sea. But though thus confined to particular spots, from which the individuals of the species never wander, the species itself may be said to be repeated again in different and distant regions, separated from each other by almost insurmountable obstacles. Thus, many of what may be termed stationary species are found identically the same along the coasts of Brazil, in the Arabian Gulf, and over the multiplied shores of Polynesia. It has hence been concluded that such species, incapable of colonizing them- 
selves by leaving their accustomed shores, and hazarding a journey across unknown oceans, have either been created in more places than one, or have been enabled to transport themselves by means different from any of those which are now available in the ordinary course of nature.*

If the natural means by which the more powerful species, inhabiting the saline waters of the ocean, have spread themselves from clime to clime, be in some measure within the reach of our comprehension, it is otherwise with those peculiar to rivers and the waters of inland lakes. How these have contrived to migrate from one region to another, and to people with identical species the depths of far-removed and solitary waters, separated from each other by chains of lofty mountains, or wide-extended wastes of desert sand, is a problem which, in the present state of our knowledge, we seek in vain to solve. $\dagger$

Of the genus Murana several species occur in the African seas. The spotted muræna ( $M$. guttata) was observed by Forskall in the Red Sea. A small species of goby, scarcely exceeding an inch in length, is found in the Nile. It is the Gobius aphya of Linnæus. We may here mention, that the name aphya, by which this species has been distinguished, seems to have been applied by the ancient writers to such small fishes as they vaguely supposed to have been produced rather from the foam of the ocean than according to the usual process of nature. $\neq$ Several species of bull-head (Cottus) are described by Commerson, and the genus Scorpana, so eccentric in its forms, is represented in the African seas, among others, by the Cape scorpæna (S. Capensis), mentioned by Gronovius. A magnificent fish, called the opah dory (Zeus luna), inhabits the African shores. Dr. Mortimer exhibited a fish of this kind to the Royal Society in 1750, which was taken " on the coast of Leith ;" and he adds (in the Phil. Trans. for that year), that the Prince of Anamaboe, being then in England, immediately recognised it, and said it was common in his country, and was excellent eating.

\footnotetext{
* See Gaymard's Mémoire sur la Distribution Géographique des Poissons.

t See further on this subject the 5th number of my Illustrations of Zoology.

‡ See Shaw's General Zoology, vol.v. p. 245.
} 
The Remora, so remarkable for its faculty of adhering to other fishes by a peculiar sucker-shaped organ on the top of its head, is found in the Mediterranean and other saline waters which wash the African shores. The olive-green remora (Echeneis cauda rotundata of Bloch) is common on the coasts of Mozambique. A species of Labrus (L. Niloticus) inhabits the Nile ; and the star-eyed Bodian (Bodianus stellifer) is native to the seas about the Cape. The silvery mackarel (Scomber crumenophthalmus) is found in considerable plenty about the coasts of Guinea, and the Scomber chloris is also an African species.

The surmullet (Mullus ruber) so famous as an epicurean delicacy among the Romans, and so highly, though not very humanely, admired for the splendour of its dying hues, is found both along the African and European shores of the Mediterranean. "Vide," says Seneca, "quomodo exarserit rubor omni acrior minio! vide quas per latera venas agat! Ecce! sanguinem putes ventrem! quàm lucidum quiddam cœruleumque sub ipso tempore effulsit! jam porrigitur et pallet, et in unum colorem componitur !" The flying gurnard (Trigla volitans) may likewise be mentioned as a Mediterranean species of singular habits and great beauty. It swims in shoals and delights the voyager by its short and frequent flights.

The electric silure (Silurus electricus) dwells in the rivers of Africa. It was observed by Forskall in the Nile, by whom, however, in his Fauna Arabica, it is improperly named Raja torpedo. Another species of Silurus called platte-kop, or flat-head, occurs in the fresh waters of Southern Africa. Mr. Burchell observed two boys of the Bushmen tribe fishing for this species. They stood by the water-side, motionless as herons. After waiting patiently for half an hour, a fish came within their reach, and was instantly pierced through with their spears or assagays. It was nearly three feet long, entirely of a lead colour, but approaching to white underneath. The head was very broad and flat, the eyes pale yellow and extremely small, and the mouth was bearded with several very long strings. The flesh was white, rich, and nutritious. This fish seems to occur only in those rivers which run to the western coast (that is, to the northward of the Cape of Good Hope), . while, on the other hand, eels have never been seen in any but those whieh fall into the ocean eastward of that cape. 
Of the salmon genus, the Salmo fulvus, a fierce and hungry fish, is much esteemed as an article of food by the inhabitants of Guinea. The notable genus Polypterus was first scientifically distinguished by M. Geoffroy. Its shape is long, cylindrical, and serpentiform; the head is defended by large bony plates; and the body is covered by strong scales, resembling those of a coat of mail. This fish is called bichin by the Egyptians, and is considered as very rare. It is said to dwell in the soft mud of the Nile, and is the finest flavoured of all the Nilotic fishes; but as it is hardly possible to open the skin with a knife, the fish is first boiled, and the skin afterward drawn off almost entire. The tooth-tongued argentine ( $A$. Glossodonta) is a beautiful species, native to the Red Sea ; and the pearl-bladdered argentine (A. Sphyrana) is a Mediterranean fish of the same genus. The air-bladder of this species is equally bright and beautiful with its external parts, and along with these is much used in the preparation of artificial pearls.

The flying-fish (Exocatus exiliens) is remarkable for the great length of its pectoral fins, which enable it to sustain itself above the waves for several hundred yards. The silvery polyneme ( $P$. Niloticus) is a very elegant fish, of great excellence as an article of fond. Its mode of capture in the Nile is described by Bruce. The ten-fingered polyneme $(P$. decadactylus), likewise esteemed a very wholesome and agreeable fish, occurs along the coasts of Guinea, and occasionally enters the rivers of that country. Of fishes allied to the herring, Africa produces several species. The Clupea Africana is said to be extremely plentiful during the summer months in the last-named district; and the dorab herring $(\boldsymbol{C}$. dorab) is described by Forskall as native to the Red Sea. Among the carp tribe we shall merely mention the Cyprinus gonorhynchus, mentioned by Gronovius as an inhabitant of the Cape seas. We may observe in passing, that a great variety of fish are caught in the salt waters which environ the Cape; but fresh fish are there so rare, that Mr. Burchell "does not recollect having seen any at table except eels, and these were regarded as a curiosity."* The genus Mormyrus seems almost entirely peculiar to the Nile.

Of the cartilaginous fishes, several species of ray inhabit * Travels, vol. i. p. 79. 
the African seas. For example, the Raja guttata was seen by Commerson along the coasts of Madagascar, and the lymna and pearled rays ( $R$. lymna and sephen) both occur in the Red Sea. It is from the skin of the last-named species that the beautiful substance called Galluchat by the French is prepared. It is tinted with blue, green, or red, according to the taste of the artist, and being afterward polished, is used in the manufacture of different kinds of cases, telescope-tubes, \&c. The younger specimens, according to La Cépède, are preferred,- the tubercular coat of the full-grown individuals being rather too rough for the desired purpose. Several species of shark inhabit the African seas. They are disagreeable to bathers.

The extraordinary genus Ostracion, or trunk-fish, distinguished by the peculiar bony crust or covering in which it is enveloped, is widely distributed over the Indian and American oceans. Of the African species we may name the tuberculated trunk-fish (C. tuberculatus), by some regarded as a mere variety of Ostracion triqueter, a kind much esteemed for the uses of the table in the East Indies. The not less remarkable tribe included in the genus Tetrodon are represented in Africa by the lineated species ( $T$. lineatus) which sometimes occurs in the Nile, where Hasselquist was assured by the fishermen, that on seizing this fish in the water their hands were frequently stung as if by nettles.

The last genus to which we shall allude is that called Syngnathus, or pipe-fish. Some of these are found in the northern seas, others in the equatorial; while the most remarkable of all is the foliated pipe-fish (Hippocampus foliatus, Cuvier), which has hitherto occurred only along the shores of New-Holland and Van Dieman's Land. The pelagic pipe-fish (S. pelagicus) is found in the African seas.

We shall close our ichthyological department by two short extracts. "I was present," says M. Adanson, " at a very extraordinary capture of fish, made the same month (March, 1750) on the coast of Ben, within a league of the island Goree, by the company belonging to one of the East India ships, which had anchored in the road. They had only a net of about sixty fathoms, which they threw at a venture into the sea; for they were not so lucky as to espy any of those shoals of fishes : yet they had such surprising 
success, that the shore was covered the whole length of the net with the fish they caught, though the net was in a bad condition. I reckoned part of them, and judged that they might in all be upwards of 6000 , the least of them as large as a fine carp. There you might see pilchards, rock-fish, mullets, or gull-fish, of different sorts ; molebats, with other fishes very little known. The negroes of the neighbouring village took each their load, and the ship's crew filled their boat until it was ready to sink, leaving the rest on the seashore. In any other country, such a capture of fish would, without all doubt, pass for a miracle."*

The fossil fish of Africa are scarcely known. The following passage, in illustration of that curious branch, is from Lichtenstein's Travels - - "In the slate-stone from which the spring rose were the impressions of an innumerable multitude of fishes. We perceived this extraordinary appearance first upon the surface ; but the impressions were larger, more distinct, and finer in proportion as we broke deeper and deeper into the stone. The form of the fish resembled that of the eel, and the length of the largest was about three feet. The brittleness of the slate made it impossible for us to get out a single specimen entire ; and the fragments which we preserved, for the purpose of examining them at our leisure, were afterward destroyed by the jolting of the wagon. The more I made myself acquainted with this country by my subsequent travels, the more remarkable did the phenomena appear to me, as being the only remains of a former world which I found throughout the whole of Southern Africa." $\dagger$ We must now proceed to the next division of our subject.

The Mollusca and Conchifera of Africa next demand our attention. To these extensive classes belong whatever species are known under the general names of shellfish and shells. The precise localities of African conchology are, in truth, so superficially. ascertained that, even if the portion of our present volume originally allotted to the zoological department had not been already much more than exhausted, we should have found great difficulty in

* Voyage to Senegal, p. 178.

$\uparrow$ Travels in Southern Africa, vol. 1. p. 95. 
satisfying either ourselves or our readers. In the absence, however, of fuller and more circumstantial information, we must rest contented with the following brief details :-

The shells of the warmer regions of the earth, as well as the birds and insects, are generally distinguished from those of colder countries by the greater beauty of their forms and colouring ; and those of Africa, while they participate in this splendid character, are yet more highly valued in consequence of their comparatively rare occurrence in collections. The productions of the African seas are probably less known than those of any other quarter of the globe.

The Mediterranean affords very 'numerous species, although the very slight changes of level which its waters undergo render its testaceous productions less easily obtained than in more northern latitudes,

"Where the redundant seas wash up fresh stores."

A few of the more remarkable animals of these classes which occur in the Mediterranean are,-several kinds of cuttle-fish, such as Sepia officinalis, Loligo vulgaris, and $L$. sepiola; Argonauta Argo, Janthina communis, Isocardium globosum, Cardita sulcata, and ajar ; Spondylus gaderopus, Avicula tarentina, Cardium costatum, Anatina globosa, Pholas dactylus, and several Pinne. The Tyrian purple of the ancients is supposed to have been obtained from the Purpura palula, common in this sea. The use of that splendid and regal die is now superseded by the discovery of the tinctorial uses of the cochineal,- - a small and obscure insect, which the skill of the chemist has rendered indispensable even to the garments of kings.

Egxpt and the Valley of the Nile were first correctly observed by the skilful Savigny and the other naturalists of the great French expedition; afterward by Olivier, and at a still later period by Cailliaud. A few species mentioned by Poiret, those described by Chemnitz, and the collection made by the Danish naturalist Grove from Morocco, form the chief materials of our knowledge of this department along the Barbary coasts. The Red Sea, so full of shoals and coral reefs, is said to be peculiarly rich in shells ; but with the exception of the work of Forskall, and the more recent travels of Lord Valentia, we can scarcely 
indicate any proper sources of information regarding that quarter.

The eastern shores of Africa are, in respect to this, as well as all other branches of natural history, almost entirely unknown.

With the species of the western coasts we are somewhat better acquaimted. Adanson described many of the shells of Senegal, and Bowdich a few from the Gambia. Maugé, Von Buch, and Bowdich made small collections from Madeira, Teneriffe, and Porto Santo. Those islands are said to be rich in peculiar species, and therefore merit more particular attention than has yet been bestowed upon them. Along the western coasts numerous species also occur which are common to the tropical seas; such as Cypraa Tigris, moneta, and helvola,-several Olives, Cones, and Volutes, the pearl-oyster, Meleagrina margaritifera, \&c.

Of the land and fresh-water shells of the interior of this continent scarcely any thing is known. Le Vaillant described only a single species from Caffraria, though Delalande afterward collected many in that country; and Bruce and Burchell have incidentally noticed a few from Abyssinia and the more southern districts.

At the Cape of Good Hope the quantities of shells which cover the beaches are immense, and the natives frequently employ them for lime: But the heavy surf which so often thunders along the shores of this promontory (the Cape of Storms) seems to prevent the shells from being frequently gathered in a perfect state; and South African specimens are therefore more rare in collections than might be expected. The coasts of Madagascar are said to be particularly rich in fine shells, although we have acquired as yet but a very meager knowledge of the testaceous productions of that great island. If its climate and political circumstances admitted of a closer and more assiduous search, treasures of great value would no doubt reward the toils of the conchological collector.

The northern and western coasts, though separated by so wide an extent of barren sands, offer in this department a few remarkable analogies. The Anadonta rubens of the Nile is found specifically the same in Senegal, and the Helix flammata of Nubia has been observed along the banks. of the Gambia. Among the African shells, a few occur 
extensively distributed over other countries. The Bulla striata is found in Egypt and Senegal, along the coasts of France and England, in the Antilles, and South America. The Turbo petreus, well known in Europe, is equally familiar to the sun-burnt collector at the Cape. The Helix aspersa, so aburdant in all the temperate countries of Europe, has also been found in Africa, and as far west as the Canary Islands. Another species, the Helix candidissima, frequent in France and Spain, has been found in Tripoli and other parts of the African continent. The Helix agira of Egypt and Barbary is found in Provence, though not in Italy; while the Helix lactea of Spain and Algiers is unknown in Provence, yet extends northward as far as Rousillon.

Of other African shells we shall mention merely the Cassis Madagascariensis, Patella granaiina and testudinaria, Conus ammiralis, - a species highly prized by collectors, Voluta armata, Haliotis striata, and Olina erythrostoma.

The fossil shells of an extremely limited portion of Africa are partially exhibited in the great French work on Egypt ; and those of Mount Barkal have been illustrated by M. Cailliaud.

Our knowledge of the geographical distribution of Insects, notwithstanding the more careful study of the subject which has prevailed of late years, may be said to be still in its infancy. Latreille's little work, however imperfect, is the most complete with which we have as yet been furnished.*

It is easy to suppose that if certain plants are peculiar to certain climates, so also insects, the greater proportion of which not only feed on plants, but are each according to its kind almost restricted to particular species, must in like manner be characteristic of special localities. The entomological characters of the southern shores of Europe strongly exhibit their geographical approach to the African continent. The Ateuclus sacer, various species of Scaurus and Akis, the European scorpion, several Cigalce, Termites, and others, may be regarded, in the southern countries of Europe, as the avant-courriers of those more exclusively

\footnotetext{
* "Introduction da la Geographie Générale des Arachnides et des Insectes, ou des Climats propres à ces Animaux." This mernoir was read to the Academy of Sciences in 1815, and forms part of the third volume of the Mémoires du Musium d'Histoire Naturelle." It was republished in a separate volume by the same author, entitled "Memoires sur divers Sujets de PHistoire Naturelle des Insectes," \&c. Paris, 1819.
} 
African forms which have their centre of dominion in the burning deserts. Along the Mediterranean shores, the traveller may study the habits of many curious insects, belonging to the genera Mygale, Onitis, Cebrio, Pimelia, Brachycerus, Brentus, and Scarytes, and may also enrich his collection by the capture of many beautiful butterflies, and other lepidopterous insects, which are more truly characteristic of Northern Africa. Spain especially exhibits many features of African zoology. The European entomologist there finds, for the first time, several species of the following genera :-Erodius, Sepidium, Zygia, Hemoptera, Galeodes, Brachinus, and Pimelia. But it is only after crossing the Mediterranean, and traversing the African shores, whether north of the Atlas, or eastward towards the coasts of the Red Sea, that our eyes are delighted with the hitherto unknown forms of Anthia, Graphipterus, Siagona, and numerous other species unknown to the colder and moister shores of Europe.

But no sooner do we leave the Mediterranean coasts of Africa, and enter upon the more weary and disastrous pilgrimage of the great deserts, the apparently limitless expanse of which so soon greets the eye of the yet undaunted traveller, than almost all vestiges of European life, whether human or brute, disappear; and Nubia, Ethiopia, Senegal, and a great part of Guinea exhibit entomological forms, cognate in character when compared among themselves, but separated, in every sense of the words, "longo intervallo," from those of Europe. As we proceed further southwards, where the chariot of the "Great Apollo" rolls on with a still fiercer and more fiery lustre, and the beams of a vertical sun induce even the tawny Moor and the woolly-headed negro to avoid his scorching and sometimes fatal rays, we discover many extraordinary forms of insect life, called into existence through the instrumentality of that bright effulgence which the pale-faced European has so often sought to withstand in vain. From the burning regions of Guinea, and the parched shores of the Congo, we derive the finest of those magnificent coleopterous insects, named generically Goliathus, by Lamarck. The western and equinoctial parts of Africa also yield us the species of Petalocheirus and Enceladus; while the Cape of Good Hope is remarkable for the genus Anthia and Brachycerus. The last named district is almost the exclusive domain of Manticora and Pneumora ; 
and the southern parts of Africa in general present us with Sagra, Diopsis, and Paussus, although it may be observed that some of these also occur in the East Indies. The lastnamed genus is remarkable for the very peculiar form of the antennæ. The genus does not exist in the twelfth edition of the Systema Naturc, but was published by Linnæus in a separate dissertation in 1775 . Only a single species was known at that period, and another was added in 1796, by Dr. Adam Afzelius, then residing at Sierra Leone.* The etymology of the name is supposed by Afzelius to be from the Greek ravers, signifying a pause, cessation, or rest ; for Linnæus, now old and infirm, and sinking under the weight of age and labour, saw no probability of continuing any longer his career of glory. "He might, therefore," adds Dr. Shaw, "be supposed to say 'hìc meta laborum,' as it in reality proved, at least with regard to insects, - pausus being the last he ever described." $\dagger$ It was literally, in the language of Young,-

"An awfol pause prophetic of his end!"

Both Madagascar and St. Helena present a few insects which to a certain extent demonstrate the African complexion of those islands; but the latter especially is also allied by its entomological features to some of the southwestern countries of Asia. According to Latreille, Africa furnishes no species of the genus Passalus, although it is elsewhere widely distributed orer America and the East Indies. The genera Graphyptera, Eurichora, and Pneumora are probably peculiar to Africa.

Among the hemipterous insects of Africa we may mention the Mantis precaria, an object of superstitious veneration among the Hottentots, who hold in the highest respect the person on whom the insect happens to alight.

"I here became acquainted," says Mr. Burchell, in his Travels in the Interior of Southern Africa, "with a new species of Mantis, whose presence became afterward sufficiently familiar to me, by its never failing, an calm warm evenings, to pay me a visit as I was writing my journal, and sometimes to interrupt my lucubrations by putting out

* Linn. Trans., vol. ir.

† General Zoology, rol. ri. p. 43. 
the lamp. All the mantis tribe are very remarkable insects ; and this one, whose dusky sober colouring well suits the obscurity of night, is certainly so by the late hours it keeps. It often settled on my book, or on the press where I was writing, and remained still, as if considering some affair of importance, with an appearance of intelligence which bad a wonderful effect in withholding my hand from doing it harm. Although hundreds have flown within my power, I never took more than five. I have given to this curious little creature the name of Mantis lucubrans; and having no doubt that he will introduce himself to every traveller who comes into this country in the months of November and December, I beg to recommend him as a harmless little companion, and entreat that kindness and mercy may be shown to him."*

Locusts are of common occurrence in many parts of Africa. Mr. Barrow records, that in the southern districts which he visited, the surface of an area of nearly 2000 square miles might literally be said to be covered by them. The water of a wide river was scarcely risible in consequence of the innumerable dead locusts that floated on its surface, apparently drowned in their attempts to reach the reeds which grew along its shores. Except these muchwished-for reeds, they had devoured every other green thing. Their destruction on a former occasion was sudden and singular. All the full-grown insects were driven into the sea br a tempestuous north-west wind, and were afterward cast upon the beach, where they formed a bank three or four feet high, and extending nearly fifty English miles. The smell, as may easily be supposed, was abominable, and was sensibly felt at a distance of 150 miles.

The migratory flight of the locust, and its desolating effects upon vegetation, and consequent injury both to man and beast, have afforded a frequent exercise to the pen of the poet ; but by none have their injurious inroads been so magnificently treated as by the Prophet Joel. "A day of darkness and of gloominess, a day of clouds and of thick darkness, as the morning spread upon the mountains; a great people and a strong: there hath not been ever the like, neither shall be any more after it, even to the years of

* Burehell's Travels, rol. i. p. 419. 
many generations. A fire devoureth before them, and behind them a flame burneth: the land is as the Garden of Eden before them, and behind them a desolate wilderness; yea, and nothing shall escape them. The appearance of them is as the appearance of horses ; and as horsemen, so shall they run. Like the noise of chariots on the tops of mountains shall they leap, like the noise of a flame of fire that devoureth the stubble, as a strong people set in battlearray." "The earth shall quake before them ; the heavens shall tremble: the sun and moon shall be •dark, and the stars shall withdraw their shining." "How do the beasts groan! the herds of cattle are perplexed, because they have no pasture ; yea, the flocks of sheep are made desolate."

One of the most formidable of the insect tribes of this continent is the Termes bellicosus, or white ant. This species dwells in congregated troops, consisting of labourers, soldiers, and sovereigns. They build conical nests of mud and clay, from 10 to 12 feet high, and divided in the interior by thin partitions into a variety of cells. These nests are often very numerous, and appear like villages from a distance. Jobson, in his History of Guinea, alieges that they are often 20 feet high, and he states that he found them extremely serviceable in screening himself and his companions while engaged in the pursuit of antelopes and other wild game. The queen-mother of this species becomes in the pregnant state of so enormous a size, that her abdomen exceeds by two thousand times the bulk of the rest of her body. When the ova are fully formed, they are obtruded at the rate of 60 in a minute, or upwards of 80,000 in 24 hours.

Of the butterfly tribe, of course, many beautiful species inhabit this far-spread continent ; but as little is known of their habits and history, and we would seek in vain to express by words the splendid colours, the elegant and varied forms, and the exquisite pencilling by which they are adorned, we shall not here enumerate any of the African species ;

"Nameless in dark oblivion they must dwell,"

except in the minds of those who have studied their gorgeous hues in the illumined pages of natural history, or in those fas 
more brilliant pages of the book of nature's self, where the most successful effort of art is transcended by a feeble insect's wing;-for the imagination of the poet and the painter cannot boast

\section{"Amid their gay creation hues like these"}

Several species of bee inhabit Africa. The banded bee (Apis fasciata) is an object of domestic cultivation; and in some parts of the country a particularly delicious honey is derived from the labours of this industrious insect. Wax is an object of considerable consequence in the commerce of Africa.

Scorpions and centipedes of enormous size and most forbidding aspect lurk beneath the stones, or glide with numerous feet over the sterile soil; and the poison of theșe creatures seems to exist in a stronger and more deadly state of concentration than in colder climes. Children frequently die from the bite of the scorpion in less than three days. In regard to the smaller domestic nuisances of the entomological class, we have few data from which to form an opi nion. We doubt not that dirt and indolence produce here as elsewhere their disgusting concomitants. Captain Lyon, however, observed, that although bugs were numerous, there were no fleas in Fezzan.

We come now to the last class of the animal kingdom, called Zoophytes. These, Professor Jameson has elsewhere remarked, "although the lowest in the scale of animated beings, are yet highly interesting in the sublime plan of creation. Their numbers exceed all calculation,the minuteness of many species is such that they are not to be discriminated by the aid of our most powerful microscopes,- they form one extremity of the zoological scale of magnitude, of which the other is occupied by the gigantic whale of the Polar Regions. The coral-reefs, rocks, and islands of the tropical seas are formed by very minute zoophytes. These reefs, in some regions of the earth, have been traced for a thousand miles in length, forty or fifty miles in breadth, and to depths sometimes unfathomable; yet they are the work of the most minute animals in the creation. We find, too, whole beds of rocks, even en. 
ture bills, of very old formation, extending for hundreds of miles, characterized by the corals they contain, thus proving that these animals also existed in countless numbers in a former condition of our earth, and that then as at present, they assisted materially in adding to the solid matter of the globe. Zoophytes, from the simplicity of their structure, and the geognostic relations of the rocks in which they are occasionally found, appear to have been called into existence before the other classes of animals."?

The red coral (Corallium rubrum), of which are formed so many beautiful ormaments of female dress, and the value of which as an articie of commerce is consequently great, occurs abundantly along the coasts of Tunis and the shores of the Red Sea. It is of comparatively slow growth, and is never found in such splendid masses as the madrepores. Light effects a powerful influence on its growth. "Thus, at a depth of from three to ten fathoms, it grows one foot in eight years; at the depth of from ten to fifteen fathoms, the same length in ten years; at the depth of one hundred fathoms, same length in twenty-five or thirty years; and at the depth of one hundred and fifty fathoms, the same length in forty years. It is also remarked, that in general the colour is deeper and richer in shallow than in very deep water. The coral of Barbary is not reckoned so fine as that of Italy or France." $\dagger$

The common sponge (Spongia officinalis) forms also an article of traffic along some of the African shores.

We shall conclude our sketch of African zoology by a brief notice of a dangerous and disgusting animal (Filaria medinensis), commonly called the Guinea worm. This gigantic parasite contrives, in a way best know to itself, to enter beneath the skin of the human race, especially that of the legs, where it will remain for several years, attaining in the mean time to the enormous length of ten feet, and to the thickness of a pigeon's quill. According to the place and manner of its abode, it occasions pains more or less severe; and in the more unfortunate and disastrous instances, its continued presence is followed by convulsions and death.

\footnotetext{
* Murray's Historical Account of Discoveries and Travels in Africa, rol. il p.4Ti.

$\uparrow$ Ibid, p. 473.
} 


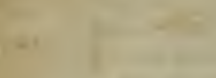
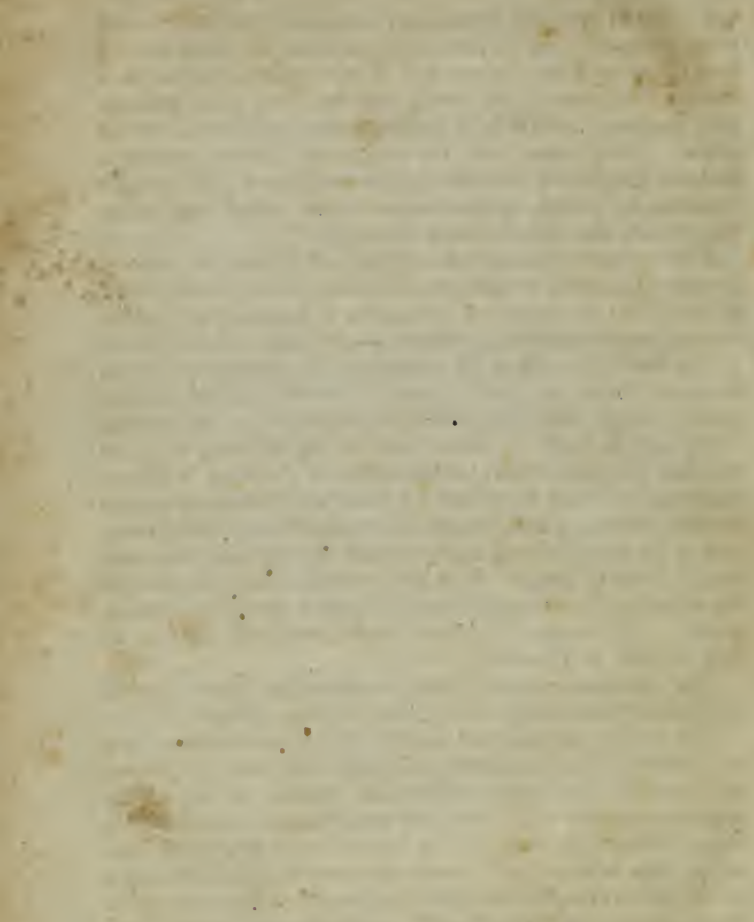

4

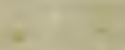

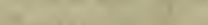<smiles>C=C(C)C(=O)O</smiles>

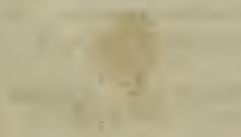





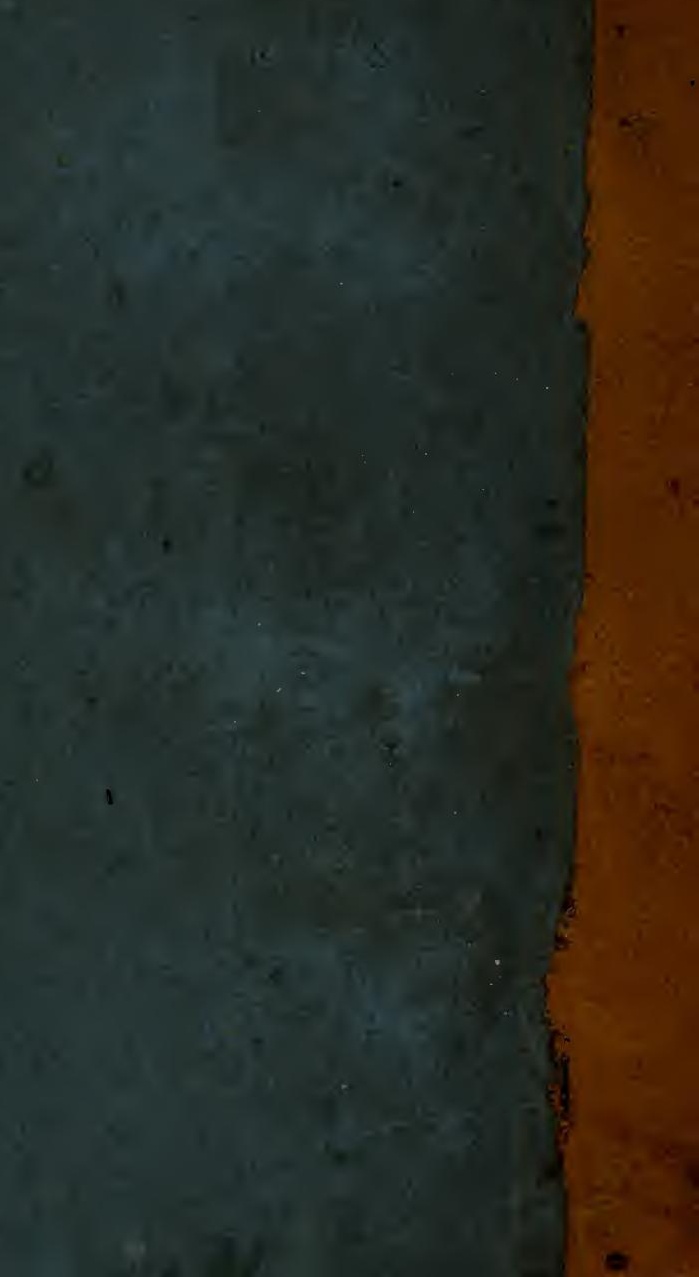

